\title{
Water Levels in the Yucca Mountain Area, Nevada, 1999
}

By Charles S. Savard

U.S. GEOLOGICAL SURVEY

Open-File Report 01-343

Prepared in cooperation with the U.S. DEPARTMENT OF ENERGY

NEVADA OPERATIONS OFFICE under

Interagency Agreement DE-Al08-97NV12033

Denver, Colorado

2001 


\section{U.S. DEPARTMENT OF THE INTERIOR GALE A. NORTON, Secretary}

U.S. GEOLOGICAL SURVEY

Charles G. Groat, Director

The use of firm, trade, and brand names in this report is for identification purposes only and does not constitute endorsement by the U.S. Geological Survey.

For additional information write to:

Chief, Earth Science Investigations Program

Yucca Mountain Project Branch

U.S. Geological Survey

Box 25046, Mail Stop 421

Denver Federal Center

Denver, CO 80225-0046
Copies of this report can be purchased from:

U.S. Geological Survey

Information Services

Box 25286

Federal Center

Denver, CO 80225 


\section{CONTENTS}

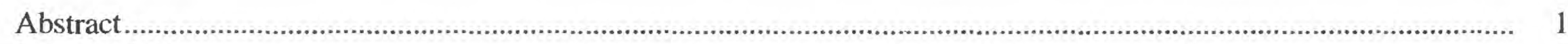

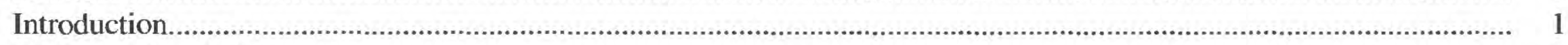

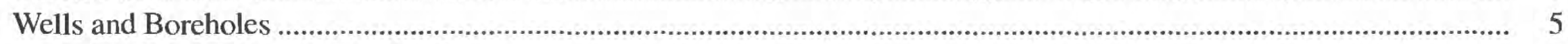

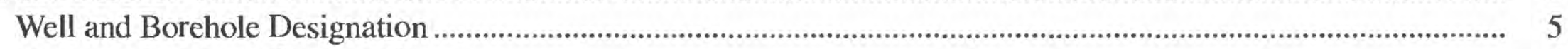

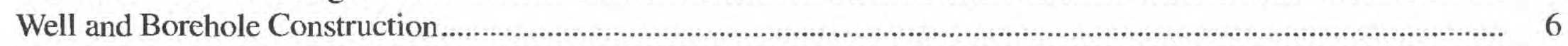

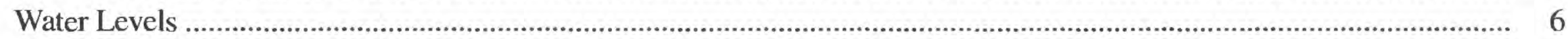

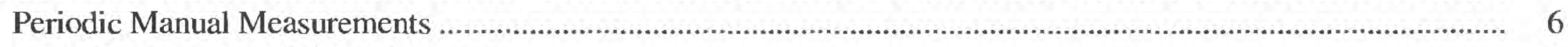

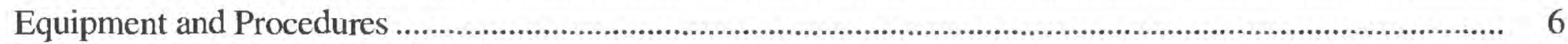

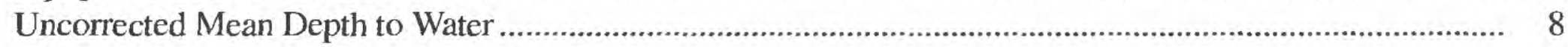

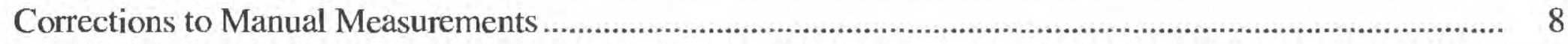

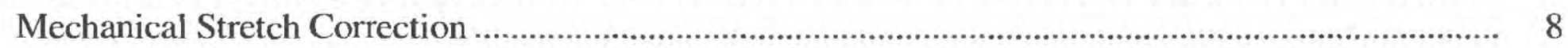

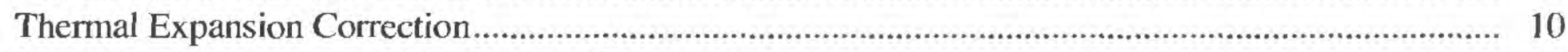

Multiconductor Cable Unit Calibration Correction ............................................................. 10

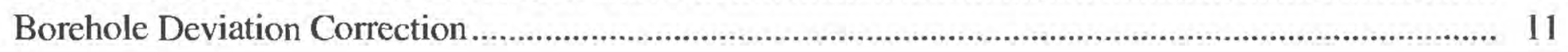

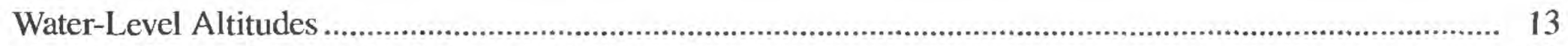

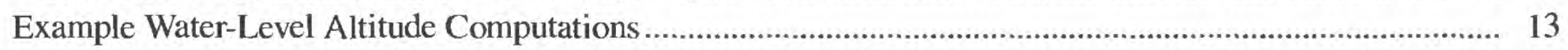

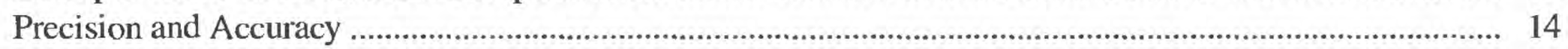

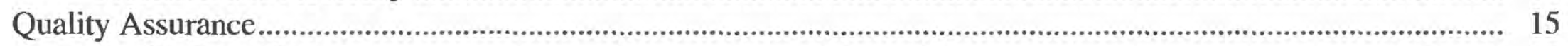

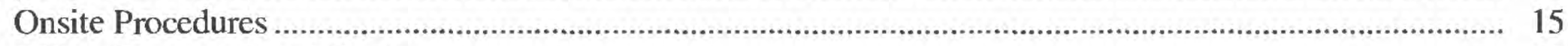

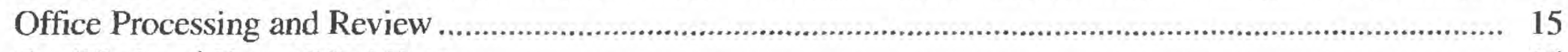

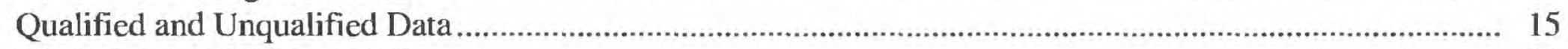

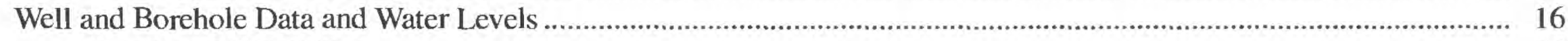

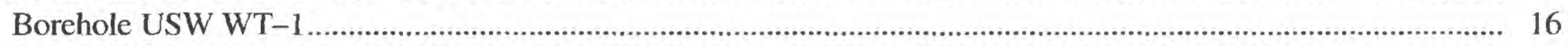

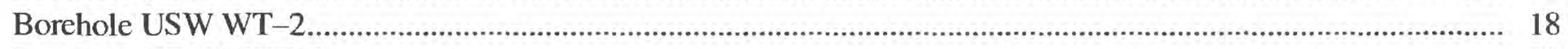

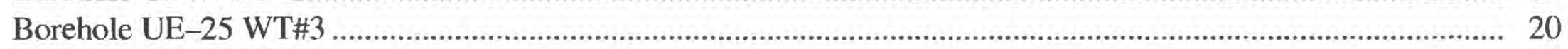

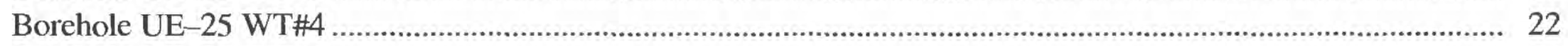

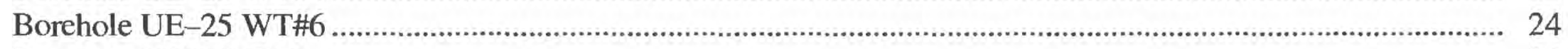

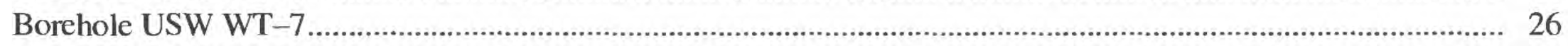

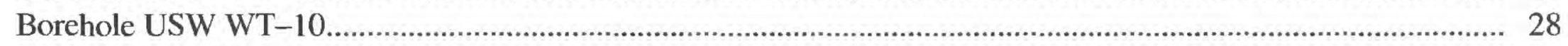

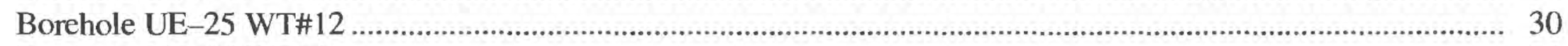

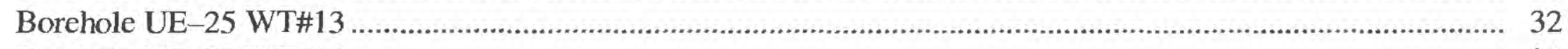

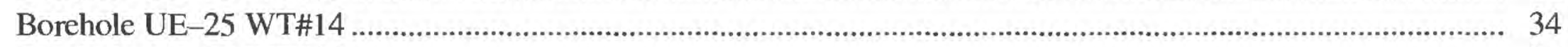

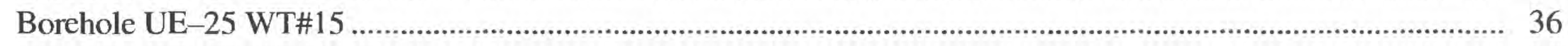

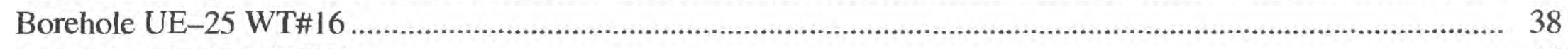

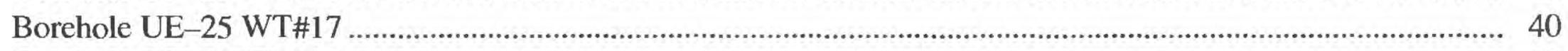

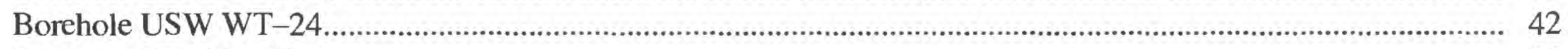

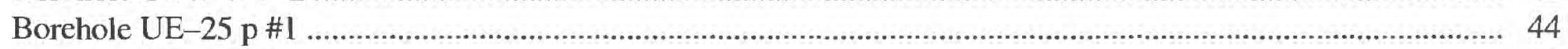

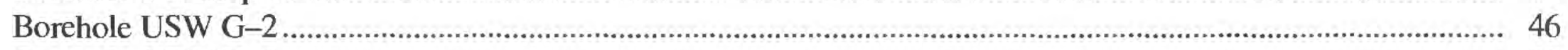

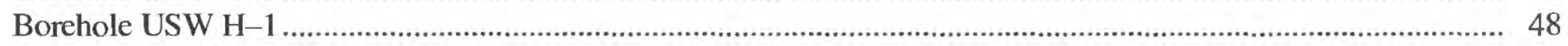

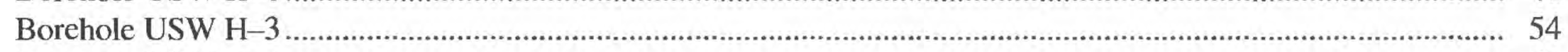

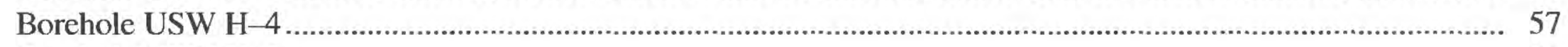

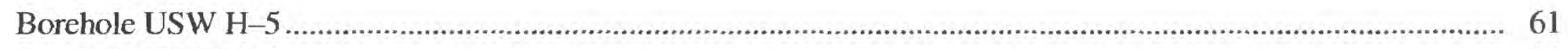

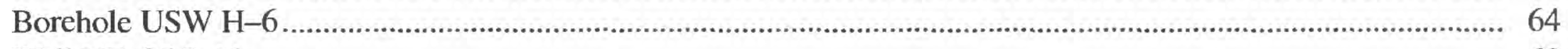

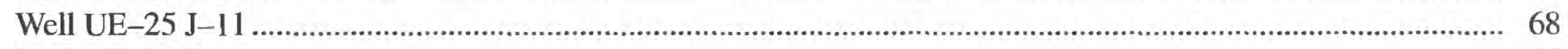

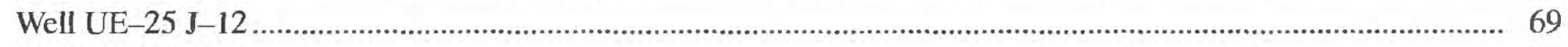

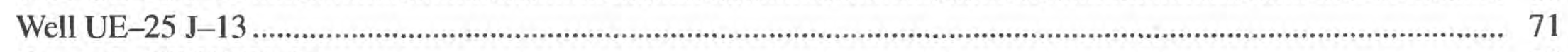

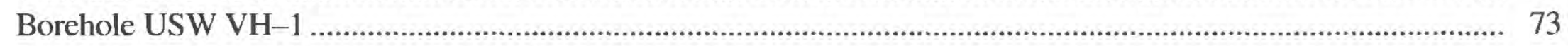

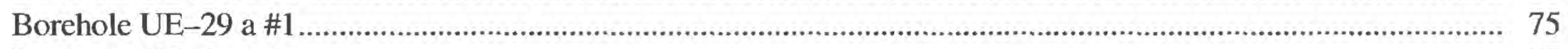

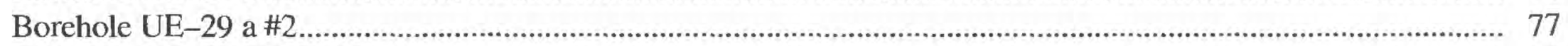

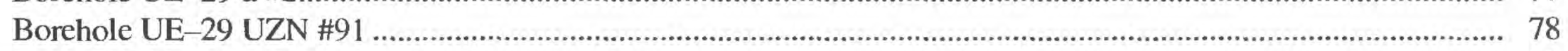

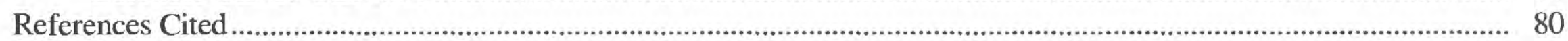




\section{FIGURES}

1. Map showing location of wells and boreholes in the Yucca Mountain area, Nevada............................................. 2

2. Chart showing selected geologic and hydrogeologic units at Yucca Mountain...................................................... 3

3-6. Graphs showing:

3. Mechanical stretch correction factors for Chain \#3 with different plumb bob weights................................. 10

4. Thermal expansion correction factors for Chain \#3 with different assumed average borehole temperature..... 11

5. Mt. Sopris multiconductor cable unit calibration correction functions ...................................................... 12

6. Borehole deviation correction for borehole UE-25 WT\#17 ................................................................ 12

7-72. Hydrographs showing:

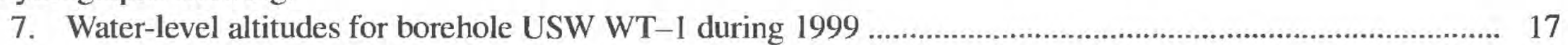

8. Annual mean water-level altitudes for borehole USW WT-1 ............................................................... 18

9. Water-level altitudes for borehole USW WT-2 during 1999 .................................................................. 19

10. Annual mean water-level altitudes for borehole USW WT-2 ............................................................... 20

11. Water-level altitudes for borehole UE-25 WT \#3 during 1999 .............................................................. 21

12. Annual mean water-level altitudes for borehole UE-25 WT \#3.................................................................. 22

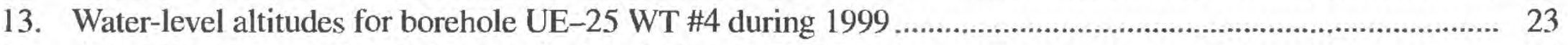

14. Annual mean water-level altitudes for borehole UE-25 WT \#4 ................................................................ 24

15. Water-level altitudes for borehole UE-25 WT \#6 during 1999 ................................................................. 25

16. Annual mean water-level altitudes for borehole UE-25 WT \#6 ............................................................. 26

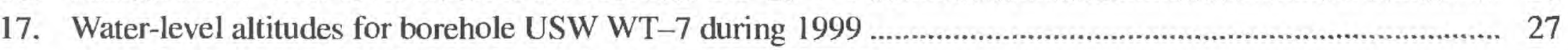

18. Annual mean water-level altitudes for borehole USW WT-7 _.................................................................. 28

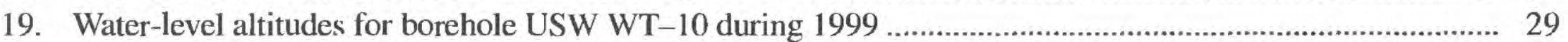

20. Annual mean water-level altitudes for USW WT-10 ........................................................................ 30

21. Water-level altitudes for borehole UE-25 WT \#12 during 1999 ............................................................ 31

22. Annual mean water-level altitudes for borehole UE-25 WT \#12 ........................................................ 32

23. Water-level altitudes for borehole UE-25 WT \#13 during 1999 …...................................................... 33

24. Annual mean water-level altitudes for borehole UE-25 WT \#13 ............................................................... 34

25. Water-level altitudes for borehole UE-25 WT \#14 during 1999 ............................................................. 35

26. Annual mean water-level altitudes for borehole UE-25 WT \#14 …....................................................... 36

27. Water-level altitudes for borehole UE-25 WT \#15 during 1999 …......................................................... 37

28. Annual mean water-level altitudes for borehole UE-25 WT \#15 …............................................................... 38

29. Water-level altitudes for borehole UE-25 WT \#16 during 1999 …............................................................. 39

30. Annual mean water-level altitudes for borehole UE-25 WT \#16 ….............................................................. 40

31. Water-level altitudes for borehole UE-25 WT \#17 during 1999 .......................................................... 41

32. Annual mean water-level altitudes for borehole UE-25 WT \#17 ............................................................. 42

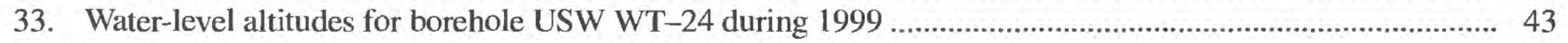

34. Water-level altitudes for borehole UE-25 p \#1 during 1999 .................................................................... 45

35. Annual mean water-level altitudes for borehole UE-25 p \#1 ............................................................... 45

36. Water-level altitudes for borehole USW G-2 during 1999 …..................................................................... 47

37. Annual mean water-level altitudes for borehole USW G-2 ...................................................................... 48

38. Water-level altitudes for borehole USW H-1, tube I, during 1999......................................................... 50

39. Annual mean water-level altitudes for borehole USW H-1, tube 1 ......................................................... 50

40. Water-level altitudes for borehole USW H-1, tube 2. during 1999 ...................................................... 51

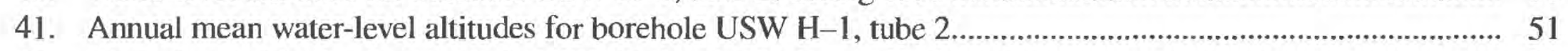

42. Water-level altitudes for borehole USW H-1, tube 3, during 1999 ........................................................... 52

43. Annual mean water-level altitudes for borehole USW H-1, tube 3 ................................................... 52

44. Water-level altitudes for borehole USW H-1, tube 4, during 1999 ….................................................. 53

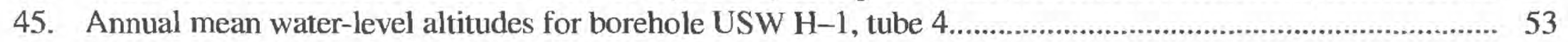

46. Water-level altitudes for borehole USW H-3, upper interval, during 1999 .............................................. 55

47. Annual mean water-level altitudes for borehole USW H-3, upper interval .................................................. 56

48. Water-level altitudes for borehole USW H-3, lower interval, during 1999................................................... 56

49. Annual mean water-level altitudes for borehole USW H-3, lower interval ................................................... 57

50. Water-level altitudes for borehole USW H-4, upper interval, during 1999................................................ 58 
51. Annual mean water-level altitude for borehole USW H-4, upper interval ................................................. 59

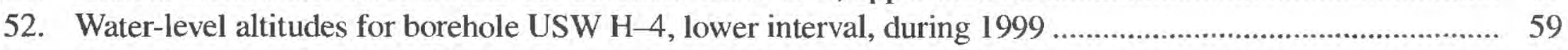

53. Annual mean water-level altitudes for borehole USW $\mathrm{H}-4$, lower interval ................................................. 60

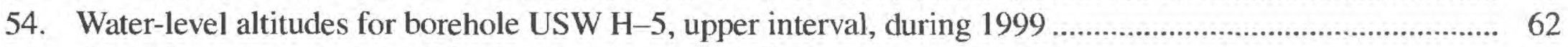

55. Annual mean water-level altitudes for borehole USW H-5, upper interval ................................................ 63

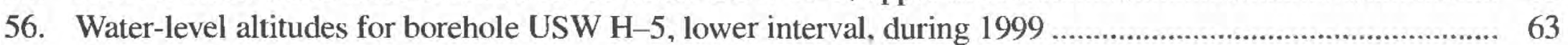

57. Annual mean water-level altitudes for borehole USW H-5, lower interval .................................................. 64

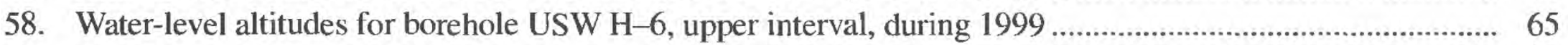

59. Annual mean water-level altitudes for borehole USW H-6, upper interval ................................................... 66

60. Water-level altitudes for borehole USW H-6, lower interval, during 1999 .............................................. 66

61. Annual mean water-level altitudes for borehole USW H-6, lower interval ................................................ 67

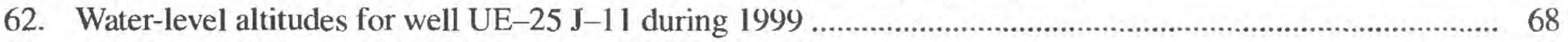

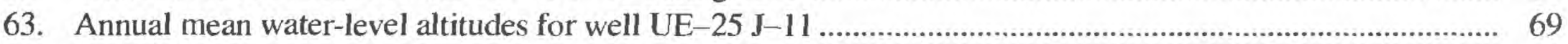

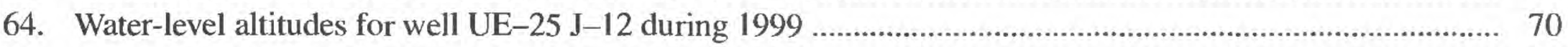

65. Annual mean water-level altitudes for well UE-25 J-12 ............................................................. 71

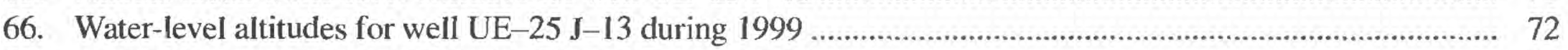

67. Annual mean water-level altitudes for well UE-25 J-13 ................................................................. 73

68. Water-level altitudes for borehole USW VH-1 during 1999 .................................................................. 74

69. Annual mean water-level altitudes for borehole USW VH-1 _................................................................ 75

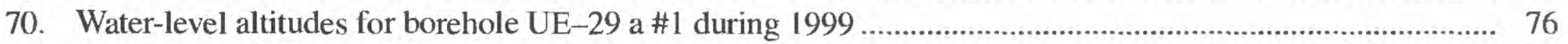

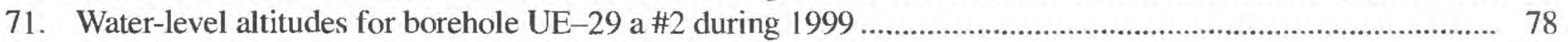

72. Water-level altitudes for borehole UE-29 UZN \#91 during 1999 ................................................................ 79

\section{TABLES}

1. Well and borehole names, U.S. Geological Survey site identifications, locations and mean water-level altitudes measured during 1998 and 1999 in the Yucca Mountain area, Nevada.

2. Mechanical stretch and thermal expansion corrections applied to water-level measurements made with the 2,800-foot reference tape and Chain \#3 and borehole deviation corrections during January through September 1999, and measurement and reference point altitude data for 1999.

3. Mechanical stretch and thermal expansion equation variable values for the 2,800-foot reference steel tape and Chain \#3

4-38. Measured water-level altitudes, 1999, for:

4. Borehole USW WT-1

5. Borehole USW WT-2

6. Borehole UE-25 WT \#3

7. Borehole UE-25 WT \#4

8. Borehole UE-25 WT \#6

9. Borehole USW WT-7

10. Borehole USW WT-10 .

11. Borehole UE-25 WT \#12

12. Borehole UE-25 WT \#13

13. Borehole UE-25 WT \#14

14. Borehole UE-25 WT \#15

15. Borehole UE-25 WT \#16.

16. Borehole UE-25 WT \#17

17. Borehole USW WT-24

18. Borehole UE-25 $\mathrm{p} \# 1$

19. Borehole USW G-2

20. Borehole USW H-1, Tube 1 .

21. Borehole USW H-1, Tube 2 .

22. Borehole USW H-1, Tube 3 .

23. Borehole USW H-1, Tube 4

24. Borehole USW $\mathbf{H}-3$, upper interval.

25. Borehole USW $\mathrm{H}-3$, lower interval. 


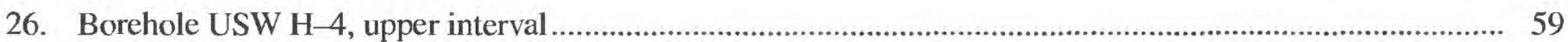

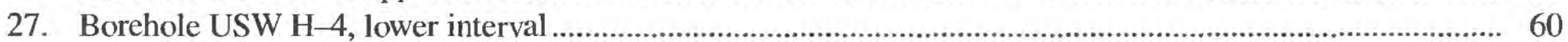

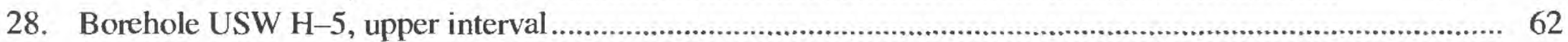

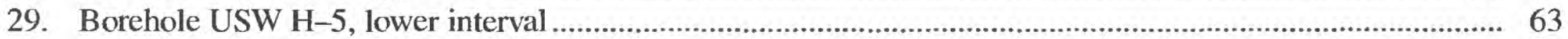

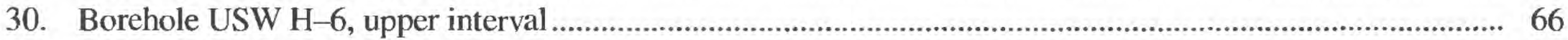

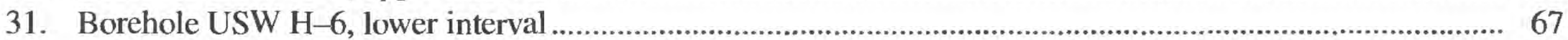

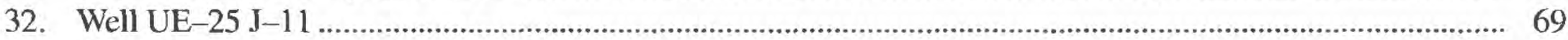

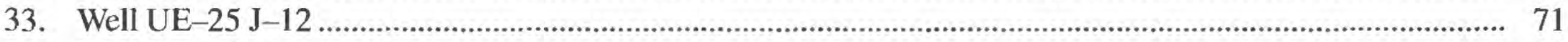

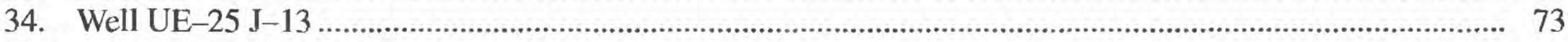

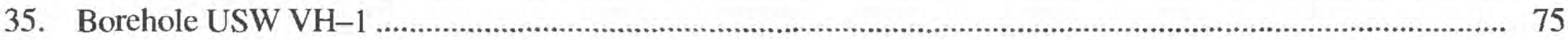

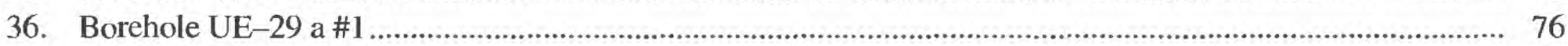

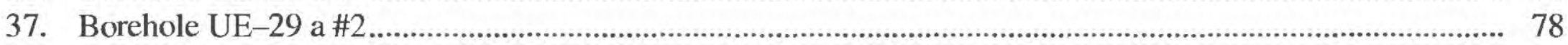

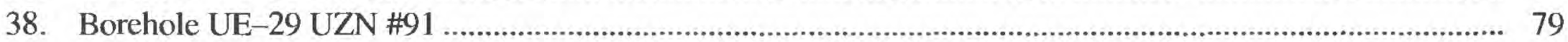

\section{CONVERSION FACTORS AND ABBREVIATIONS}

\begin{tabular}{rll}
\hline Multiply & By & To obtain \\
\hline meter $(\mathrm{m})$ & 3.281 & foot \\
millimeter $(\mathrm{mm})$ & 0.03937 & inch \\
kilometer $(\mathrm{km})$ & 0.6214 & mile \\
square kilometer $\left(\mathrm{km}^{2}\right)$ & 0.3861 & square mile \\
kilogram $(\mathrm{kg})$ & 2.205 & pound avoirdupois \\
$\operatorname{liter}(\mathrm{L})$ & 0.03531 & cubic foot \\
foot $(\mathrm{ft})$ & 0.3048 & meter \\
\hline
\end{tabular}

Sea level: In this report "sea level" refers to the National Geodetic Vertical Datum of 1929 (NGVD of 1929)-a geologic datum derived from a general adjustment of the first-order level nets of both the United States and Canada, formerly called Sea Level Datum of 1929. 


\title{
Water Levels in the Yucca Mountain Area, Nevada, 1999
}

\author{
By Charles S. Savard
}

\section{Abstract}

Water levels were monitored periodically in 35 depth intervals in 3 wells and 25 boreholes in the Yucca Mountain area, Nevada, during 1999. The water levels in the majority of the wells and boreholes represent the water table in the Yucca Mountain area. The majority of the wells and boreholes monitor potentiometric levels in Tertiary volcanic rocks. Five of the boreholes are constructed to monitor the water table as well as potentiometric levels in underlying rock layers. One borehole monitors potentiometric levels in Paleozoic carbonate rocks.

Mean water-level altitudes in the Tertiary volcanic rocks ranged from 727.96 to 1,187.99 meters above sea level during 1999. The mean water-level altitude in the borehole monitoring the Paleozoic carbonate rocks was 752.93 meters above sea level during 1999.

Annual mean water-level altitudes rose in 24 intervals from 1998 to 1999 . Annual mean water-level altitudes declined in three intervals from 1998 to 1999. Eight intervals did not have annual mean water-level altitudes available for both 1998 and 1999 and were not compared.

\section{INTRODUCTION}

The Yucca Mountain area is being evaluated by the U.S. Department of Energy for suitability to store high-level radioactive waste in a mined, underground repository. A $150-\mathrm{km}^{2}$ area located about $150 \mathrm{~km}$ northwest of Las Vegas in southern Nevada is being studied extensively (fig. 1). Water levels in selected wells and boreholes have been measured periodically since 1981. The purpose of the water-level monitoring program is to document the temporal and areal variability of the ground-water system. The areal variability is used to gain a better understanding of the ground-water flow system in the area. The water-level data can be used to determine the direction and rate of ground-water flow and to estimate hydraulic parameters of the flow system. The temporal variability is used to gain a better understanding of processes such as recharge, pumping effects, and earthquake effects. Luckey and others (1996) discuss in detail the saturated zone ground-water-flow system of the Yucca Mountain area. In most of the Yucca Mountain area, the water table is in the lower volcanic aquifer (fig. 2), which consists of Tertiary-age volcanic rocks of the Crater Flat Group (Prow Pass, Bullfrog, and Tram Tuffs). Underlying the lower volcanic aquifer is the lower volcanic confining unit. Underlying the lower volcanic confining unit is a carbonate rock aquifer of Paleozoic age (Cambrian to Devonian). In the area surrounding Yucca Mountain the water table also occurs in Quaternary alluvium in some places. The nomenclature used in this report for stratigraphic units in the study area was defined by Sawyer and others (1994, p. 1305).

This report presents the 1999 water-level data and describes the equipment and methods used to collect and process the water-level data. The waterlevel network during 1999 included 3 wells and 25 boreholes representing 35 depth intervals (table 1 ). All 1999 water levels included in this report were collected periodically by means of manual measurements.

This report is a companion and supplement to other reports that present water levels for site characterization studies in the Yucca Mountain area (Robison and others, 1988; Gemmell, 1990; O'Brien, 1991; Boucher, 1994b; Luckey and others, 1993; Lobmeyer 


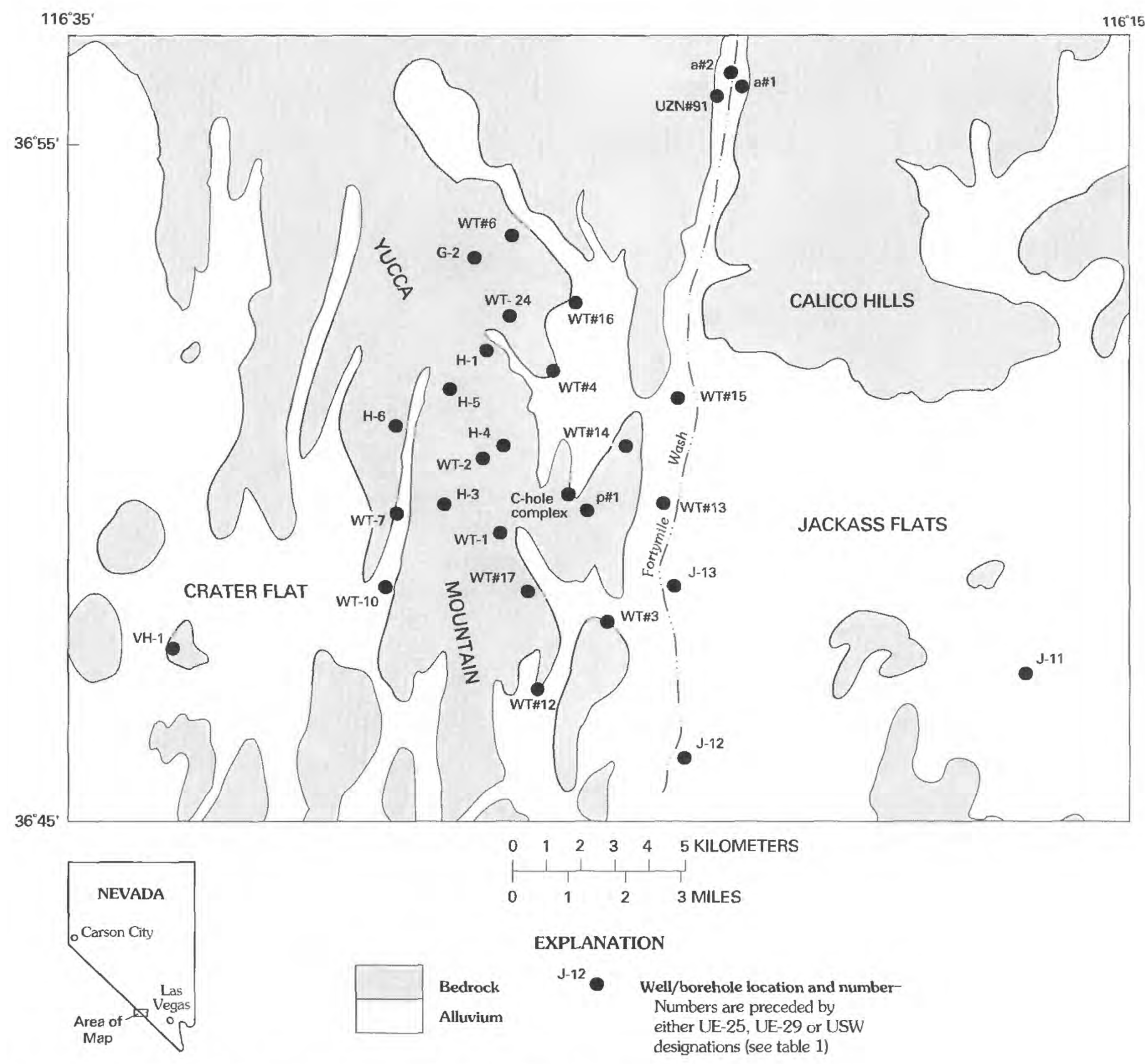

Figure 1. Location of wells and boreholes in the Yucca Mountain area, Nevada.

and others, 1995; O'Brien and others, 1995; Tucci, O'Brien, and Burkhardt, 1996; Tucci, Goemaat, and Burkhardt, 1996; Graves and others, 1996; Graves and others, 1997; Graves and Goemaat, 1998; Graves. 1998; and Graves, 2000). Water levels in Fortymile Canyon boreholes are included in this series for the first time; previous water levels were published in other reports (Savard, 1995; 1996; 1998). The U.S. Geological Survey also conducts environmental moni- toring studies in the Yucca Mountain area and reports on water-levels in wells and boreholes (La Camera and Westenburg, 1994; Hale and Westenburg, 1995: Westenburg and La Camera, 1996; La Camera and others, 1996; La Camera and Locke, 1998; and La Camera and others. 1999).

The water-level data were obtained as part of the Yucca Mountain Project of the U.S. Department of Energy. The Yucca Mountain Project is described by a 


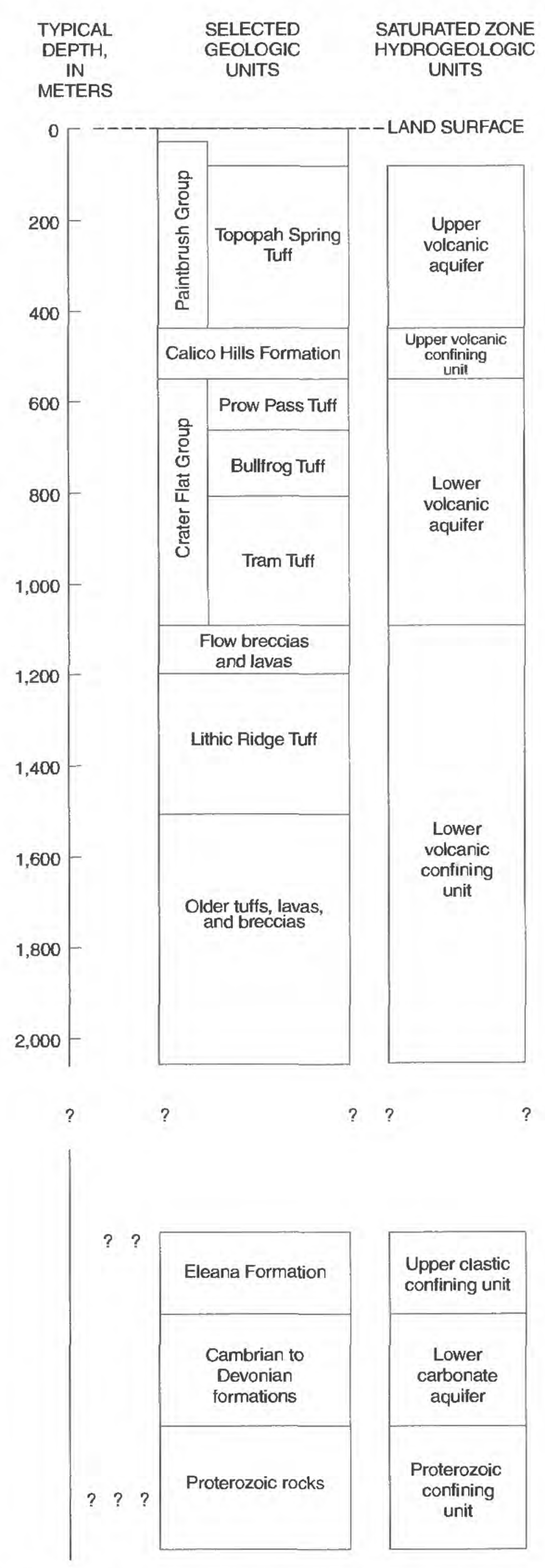

Figure 2. Selected geologic and hydrogeologic units at Yucca Mountain (adapted from Luckey and others, 1996, figure 7). 
Table 1. Well and borehole names, U.S. Geological Survey site identifications, locations, and mean water-level altitudes measured during 1998 and 1999 in the Yucca Mountain area, Nevada

\begin{tabular}{|c|c|c|c|c|c|}
\hline \multirow[b]{2}{*}{ Well or borehole name } & \multirow{2}{*}{$\begin{array}{l}\text { U.S. Geological } \\
\text { Survey site } \\
\text { identification }\end{array}$} & \multicolumn{2}{|c|}{ Location } & \multirow{2}{*}{$\begin{array}{c}1998 \text { Mean water- } \\
\text { level altitude } \\
\text { (meters above sea } \\
\text { level) }\end{array}$} & \multirow{2}{*}{$\begin{array}{l}1999 \text { Mean water- } \\
\text { level altitude } \\
\text { (meters above sea } \\
\text { level) }\end{array}$} \\
\hline & & $\begin{array}{l}\text { Northing } \\
\text { (meters) }\end{array}$ & $\begin{array}{l}\text { Easting } \\
\text { (meters) }\end{array}$ & & \\
\hline USW WT-1 & 364916116265601 & 229,802 & 171,828 & 730.22 & 730.31 \\
\hline USW WT-2 & 365023116271801 & 231,850 & 171,274 & 730.50 & 730.56 \\
\hline UE-25 WT \#3 & 364757116245801 & 227,379 & 174,768 & Not Available & 729.68 \\
\hline UE-25 WT \#4 & 365140116260301 & 234,242 & 173,138 & 730.75 & 730.83 \\
\hline UE-25 WT \#6 & 365340116264601 & 237,920 & 172,067 & 1034.76 & $1,034.95$ \\
\hline USW WT-7 & 364933116285701 & 230,298 & 168,826 & 775.94 & 775.96 \\
\hline USW WT-10 & 364825116290501 & 228,226 & 168,647 & 776.07 & 776.11 \\
\hline UE-25 WT \#12 & 364656116261601 & 225,469 & 172.825 & 729.35 & 729.44 \\
\hline UE-25 WT \#13 & 36494511623500 I & 230,699 & 176,431 & 729.13 & 729.22 \\
\hline UE-25 WT \#14 & 365032116243501 & 232,151 & 175,324 & 729.57 & 729.67 \\
\hline UE-25 WT \#15 & 365116116233801 & 233,512 & 176,725 & 729.25 & 729.30 \\
\hline UE-25 WT \#16 & 365239116253401 & 236,043 & 173,856 & 738.28 & 738.36 \\
\hline UE-25 WT \#17 & 364822116262601 & 228,119 & 172,581 & Not Available & 729.66 \\
\hline USW WT-24 & 365301116271301 & 236,739 & 171,398 & Not Available & 840.07 \\
\hline $\mathrm{UE}-25 \mathrm{p} \# 1$ & 364938116252102 & 230.481 & 174,188 & 752.86 & 752.93 \\
\hline USW G-2 & 365322116273501 & 237,386 & 170,842 & 1.019 .48 & $1,019.44$ \\
\hline USW $\mathrm{H}-1$ tube 1 & 365157116271202 & 234,774 & 171,416 & 786.14 & 786.08 \\
\hline USW $\mathrm{H}-1$ tube 2 & 365157116271203 & 234,774 & 171,416 & 735.15 & 735.05 \\
\hline USW $\mathrm{H}-1$ tube 3 & 365157116271204 & 234,774 & 171.416 & 730.62 & 730.70 \\
\hline USW $\mathrm{H}-1$ tube 4 & 365157116271205 & 234,774 & 171,416 & 730.80 & 730.85 \\
\hline USW $\mathrm{H}-3$, upper interval & 364942116280004 & 230,594 & 170,216 & Not Available & 731.89 \\
\hline USW H-3, lower interval & 364942116280005 & 230,594 & 170,216 & Not Available & 732.19 \\
\hline USW H-4, upper interval & 365032116265402 & 232.149 & 171,880 & 730.30 & 730.40 \\
\hline USW H-4, lower interval & 365032116265403 & 232,149 & 171,880 & 730.43 & 730.47 \\
\hline USW H-5, upper interval & 365122116275502 & 233,670 & 170,355 & 775.43 & 775.50 \\
\hline USW H-5, lower interval & 365122116275503 & 233,670 & 170,355 & 775.81 & 775.85 \\
\hline USW H-6, upper interval & 365049116285504 & 232,654 & 168,882 & 776.10 & 776.11 \\
\hline USW $\mathrm{H}-6$, lower interval & 365049116285505 & 232,654 & 168,882 & 775.98 & 775.99 \\
\hline $\mathrm{UE}-25 \mathrm{~J}-11$ & 364706116170601 & 225,847 & 186,467 & 732.24 & 732.26 \\
\hline $\mathrm{UE}-25 \mathrm{~J}-12$ & 364554116232401 & 223,573 & 177.092 & 727.86 & 727.96 \\
\hline $\mathrm{UE}-25 \mathrm{~J}-13$ & 364828116234001 & 228,357 & 176,677 & 728.36 & 728.44 \\
\hline USW VH-1 & 364732116330701 & 226,575 & 162,649 & 779.51 & 779.52 \\
\hline UE-29 a \#1 & 365629116222601 & 243,148 & 178,483 & Not Available & $1,187.99$ \\
\hline UE-29 a \#2 & 365629116222602 & 243,153 & 178.475 & Not Available & $1,186.49$ \\
\hline UE-29 UZN \#91 & 365624116222901 & 243,010 & 178,412 & Not Available & $1,187.17$ \\
\hline
\end{tabular}


Site Characterization Plan (U.S. Department of Energy, 1988). The data in this study were collected by the U.S. Geological Survey and its contractors in cooperation with the U.S. Department of Energy under Interagency Agreement DE-AI08-97NV 12033.

\section{WELLS AND BOREHOLES}

Depths to water were measured in 3 wells and 25 boreholes during 1999. The number of wells and boreholes differs from previous reports in this series. Two boreholes, UE-25 b \#1 and USW WT-1 1, are no longer accessible and cannot be measured for operational reasons. Three boreholes in Fortymile Canyon, UE-29 a \#1, UE-29 a \#2, and UE-29 UZN \#91, have been included in this series for the first time.

In this report wells and boreholes have slightly different meanings. Wells UE-25 J-11, UE-25 J-12, and UE-25 J-13 are boreholes drilled and used or formerly used for water-supply sources. Boreholes were drilled for hydrologic and geologic studies. Boreholes may have been pumped for short-term hydrologic experiments but are not designed nor used as water-supply sources. Borehole USW VH-1 has been used as a nonpotable water source for short periods of time.

\section{Well and Borehole Designation}

Each well or borehole used in the study of the Yucca Mountain area has a unique name or number. Wells and boreholes on the Nevada Test Site (NTS) use an NTS designation, whereas wells and boreholes off the NTS use a slightly different designation. Wells and boreholes on the NTS begin with UE (for Underground Exploratory), followed by the NTS area number (usually 25 in this report). This designation-UE-25-commonly is followed by one or more letters signifying the purpose of the well or simply by a sequential letter, followed by a sequence number. Wells and boreholes off the NTS begin with the letters

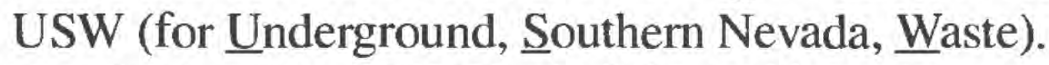
The designation-USW-is followed by one or more letters signifying the original primary purpose of the well followed by a sequence number. The letters signifying purpose that are used in this report are $\mathrm{G}$ (collection of geologic data), $\mathrm{H}$ (collection of hydrologic data), P (collection of data on rocks of Paleozoic age), UZN (collection of unsaturated-zone moisture content by neutron logging), VH (collection of hydrologic and geologic data on volcanic rocks), and WT (collection of water-table data).

Nevada State Plane North American Datum of 1927 (NAD 27) Coordinates are used to identify the location of wells and boreholes cited in this report. These coordinates are for the central zone of Nevada and are based on a Transverse Mercator projection. The origin of this projection for the central zone of Nevada is latitude $34^{\circ} 45^{\prime} \mathrm{N}$., and the central meridian is at longitude $116^{\circ} 40^{\prime} \mathrm{W}$. The Nevada State Plane NAD 27 Coordinates are in meters north of the baseline and in meters, plus 152,400 east of the central meridian (Luckey and others, 1993, p. 3). The Nevada State Plane NAD 27 Coordinate locations for the wells and boreholes were resurveyed during 1997-98 (U.S. Department of Energy, written commun., 1999, MO9907YMP99025.001). Latitude and longitude values for the wells used in this report were calculated from these 1997-98 Nevada State Plane NAD 27 Coordinates.

Each well or borehole has a U.S. Geological Survey Site Identification number (Site ID) that is used as a unique identification number of the well or borehole in the U.S. Geological Survey's National Water Information System database. The Site ID is generated by combining the original designations of the latitude and longitude with a two-digit sequence number. The Site ID is for convenience of identification only and should not be used as an actual location number because the original designations of latitude and longitude may be inaccurate. Even if original values of the latitude and longitude are revised later, the Site ID for the well is not changed. If more than one well exists within the 1-second rectangle of latitude and longitude, the two-digit sequence number ensures uniqueness of the Site ID.

Some boreholes within the water-level network have had packers or piezometers installed so the water level at discrete depth intervals can be measured. In these instances, before the packers or piezometers were installed, the borehole was assigned one Site ID (generally with a sequence number of 01) and each depth interval was assigned its own unique Site ID by incrementing the sequence number. Hence, some boreholes within the network have several Site ID's. The Site ID number for each well and borehole interval measured during 1999 are shown in table 1. 


\section{Well and Borehole Construction}

Specific information for each well and borehole is presented in the "Well and Borehole Data and Water Levels" section. Some boreholes were constructed specifically to collect hydrologic data. Other boreholes were constructed to obtain geologic or other information and then converted to obtain hydrologic data.

The WT boreholes were drilled to collect watertable altitude data. The boreholes were constructed to minimize costs and allow for greater areal coverage with the existing budget at time of construction. Typically, each well was constructed with just surface casing and then left as an open hole. Access tubing, with a section of screen, was lowered into the borehole. The access tubing was hung on a plate covering the borehole.

The hydrologic test boreholes, that is, those in the $\mathrm{H}$-series such as USW $\mathrm{H}-1$, were constructed for detailed hydraulic testing and water-level monitoring of different depth intervals. Borehole USW $\mathrm{H}-1$ has four depth intervals separated by cement plugs. Access tubing from the surface allows the water level of each isolated interval to be measured. Boreholes USW H-3, USW H-4, USW H-5, and USW $\mathrm{H}-6$ have inflatable packers installed to monitor two depth intervals within each borehole. Over time the isolating characteristics of the cement plugs and inflatable packers may have deteriorated. This is thought to be the case in USW H-3 where water-level altitudes between the two intervals have become more similar over time (Graves, 1998, p. 61). Water levels in the two intervals may be equilibrating towards a composite water level of the entire borehole rather than representing water levels in two isolated intervals. Users of data in this report are cautioned that water-level trends in some boreholes may not represent natural changes in hydrologic conditions but may represent changes in borehole hydraulics caused by deterioration of isolating material.

\section{WATER LEVELS}

During 1999 water-level data were collected periodically by manually measuring the depth to water in 3 wells and 25 boreholes and then computing waterlevel altitudes. Five of the boreholes, USW H-1, USW H-3, USW H-4. USW H-5, and USW H-6, are constructed so water levels of different depth intervals can be measured. All depth-to-water measurements and water-level altitude computations were made under a Quality Assurance program.

\section{Periodic Manual Measurements}

The depth-to-water data were collected periodically, approximately once a month during the year, or at different intervals because of operational conditions. Several different types of depth-to-water measuring equipment were used during the year. Uncorrected depth-to-water data were collected and documented in the field. Corrections to the manual measurements were made in office computations. All depth-to-water measurement equipment was calibrated to a 2,800 -foot reference steel tape or a hand-held steel tape. Waterlevel altitudes were computed from reference point altitudes and depth-to-water data. Example computations of water-level altitudes determined from depthto-water measurements using the different types of equipment are shown on pages 13-14.

\section{Equipment and Procedures}

Four pieces of equipment were used to collect depth-to-water data during 1999. Two reeled steel tapes, the 2,800-foot reference tape and Chain \#3 were used most often. A geophysical logging cable unit with a water-level probe, the Mt. Sopris Multiconductor Cable Unit (MSMCCU), was used in open uncased boreholes and in boreholes where reeled steel tape procedures did not meet water quality requirements. A hand-held steel tape was used to measure shallow depth to water in three boreholes in Fortymile Canyon.

The reeled steel tapes consist of several steel tapes riveted together, making a steel tape long enough to measure deep water levels at Yucca Mountain. The reeled steel tapes are wound onto specially designed motorized reels. The reeled steel tapes are accurate and precise (Boucher, 1994a, page 13).

A formal procedure is followed to make depthto-water measurements with a reeled steel tape a part of the Quality Assurance program. To summarize the procedure the following steps are undertaken: the motorized reel or a sheave is positioned over the borehole. The steel tape is prepared for the depth-to-water measurement by attaching double-sided adhesive tape to the lower portion of the steel tape and then affixing 
salt to the double-sided adhesive tape. A piece of clear plastic tubing is mounted over the salt-covered adhesive tape to protect the salt from rubbing off during transit down and up the borehole. The tubing allows water to enter and to touch the salted adhesive tape. The steel tape is lowered to a "hold" position where part of the salt-covered portion of the steel tape is immersed in water in the borehole. The steel tape is held for 3 minutes at the "hold" position by wooden fingers clamped over the steel tape. The hold position is a marked spot on the steel tape indicating footage. A weight at the end of the steel tape pulls the steel tape taut in a vertical direction. During the 3 minutes the bottom of the steel tape is immersed, the salt dissolves from the wetted portion of the steel tape and a "cut" mark is made at the water surface along the steel tape. After reeling up the steel tape, the "cut" is read off of the steel tape. The apparent depth to water is the distance between the "hold" position and the "cut" mark. The elevation where the "hold" position is made is known as the measurement point. The depth-towater measurement is repeated until a repeatable precision of 0.10 foot for measurements less than 1,000 feet deep or a 1 part in 10,000 (that is, 0.20 foot for 2,000-foot measurements) is obtained.

The MSMCCU is a geophysical logging cable unit with a water probe. It was used in open, uncased boreholes and in boreholes where reeled steel tape procedures did not meet water quality requirements. In open, uncased boreholes there is more risk of losing equipment down the borehole from material falling in than in a cased borehole or inside access tubing. The MSMCCU was judged to be more expendable than the reeled steel tapes and was used in the open, uncased borehole USW WT -24 . Water quality sampling requirements at two boreholes, UE-25 WT \#3 and UE-25 WT \#17, prevented the use of a salted reeled steel tape to measure depth to water. The MSMCCU was used to measure depth to water in these two boreholes in March. Chalk was determined to be an acceptable material to be used on the adhesive tape for reeled steel tape measurements in these two boreholes in April and was used from April through December.

A formal procedure as part of the Quality Assurance program is followed to make depth-to-water measurements with a cable unit such as the MSMCCU. To summarize the procedure, the following steps are undertaken: position a sheave over the borehole so the cable unit can be run down the borehole. Align the water-level probe and the measurement point, then zero the MSMCCU electronic measuring device. Lower the probe into the borehole until a water level is indicated by the surface instrumentation. Record the depth reading, which is known as the "in reading." Reel up the cable unit and align the water level probe with the measurement point. Record the depth reading for the measurement point, which is known as the "out reading." If the "out reading" is positive, then less cable was measured during reeling up than reeling down. This was probably caused by better measuring efficiency of the cable unit wheel counter during reeling up. If the "out reading" is negative, then more cable was measured during reeling up than reeling down. A negative "out reading" may be caused by grease or other material adhering to the cable which was picked up during transit up and down the borehole. The apparent depth to water below the measurement point is computed by subtracting the "out reading" from the "in reading." The depth-to-water measurement is repeated until a repeatable precision of 0.50 foot is obtained.

A hand-held steel tape, STA-1, was used to measure depth to water in three boreholes, UE-29 a \#1, UE-29 a \#2, and UE-29 UZN \#91, in Fortymile Canyon near Yucca Mountain. Shallow depth to water in these boreholes allowed the 100.99-foot-long hand-held tape to be used.

A formal procedure as part of the Quality Assurance program is followed to make depth-to-water measurements with STA-1. To summarize the procedure the following steps are undertaken: Apply a commercially available water-finding paste to the lower 0.99 foot of tape. The water paste color turns from brown to red after coming in contact with water. Lower the hand-held steel tape until a portion of the tape with the water paste comes in contact with the water in the borehole. A weight at the end of the handheld steel tape keeps the tape taut. Hold the steel tape at a marked point, known as the "hold point," at the same elevation of the measurement point. The water paste requires approximately 5 seconds to change color. Reel up the tape and read the point on the steel tape where the color changes, this is known as the "cut point." Subtract the "cut point" from the "hold point" to determine the apparent depth to water. Because STA-1 is marked in 0.01-foot increments below the zero point, the "cut point" will be a negative number. Subtracting a negative number is the same as adding 
the number; hence the name an "add steel tape." The depth-to-water measurement is repeated until a repeatable precision of 0.05 foot is obtained.

\section{Uncorrected Mean Depth to Water}

A mean apparent depth-to-water is computed from the apparent depth-to-water measurements. During the short time period the measurements are made, it is assumed the water level is stable and unchanging. The majority of the depth-to-water measurements are relatively large compared to the required repeatable precision. Minor errors in the depth-to-water measurements cause minor variations in the apparent depth to water. The mean apparent depth to water is taken to be a more precise and accurate representation of the actual depth to water than any individual depth-to-water measurement.

\section{Corrections to Manual Measurements}

Measurements made with long reeled steel tapes were corrected for mechanical stretch and thermal expansion. Measurements made with a multiconductor cable unit were corrected based on calibration results. Hand-held steel tape measurements were not corrected but were used directly. Borehole deviation corrections were made if the geophysical data were available.

Chain \#3, a reeled steel tape, was calibrated to the 2,800-foot reference tape in October 1998 and July 2000 . The calibrations indicated no calibration corrections were needed and none were applied to Chain \#3 during 1999. Chain \#3 depth-to-water measurements were used directly after corrections were made for mechanical stretch and thermal expansion.

STA-1, a hand-held steel tape, did not require any calibration and depth-to-water measurements are used directly from the field readings. STA-1 was compared to the 2,800-foot reference tape in July 2000. STA-1 was found to be reading the same depth to water within measurement error over its operating range as the 2,800-foot reference tape.

The MSMCCU was calibrated to the 2,800-foot reference tape in August 1998, August 1999, October 1999, and June 2000. Depth-to-water measurements with the MSMCCU require calibration corrections and are documented on pages 10-11 herein.

\section{Mechanical Stretch Correction}

Mechanical stretch is associated with the weight of the suspended steel tape and attached plumb bob (Garber and Koopman, 1968. p. 3-6; Robison and others, 1988, p. 9-11). The calculated adjustment for the reeled steel tapes used during January through September, based on stretch coefficients, a weight of $0.45 \mathrm{~kg}$ for the plumb bob used with Chain \#3 and the 2,800-foot reference steel tape, and approximate depth to water, ranged from -0.042 to $+0.017 \mathrm{~m}$ (table 2) for water levels measured in the vicinity of Yucca Mountain. During October through December mechanical stretch corrections were computed for each mean depth-to-water measurement value rather than using the approximate depth-to-water value.

The correction for mechanical stretch of the tape is given by:

$$
\mathrm{C}=\left(\mathrm{L}^{2} \mathrm{WS}\right) / 2+\mathrm{PLS}-\mathrm{KLS}
$$

where

$\mathrm{C}$ is the correction, in meters;

$\mathrm{L}$ is the apparent length of tape, in meters;

$\mathrm{W}$ is the unit weight of the tape, in kilograms per meter;

$S$ is the stretch coefficient, in meters per meterkilogram;

$\mathrm{P}$ is the weight of the plumb bob, in kilograms; and

$\mathrm{K}$ is the reference tension during manufacture, in kilograms.

The apparent length of tape (L) corresponds to the depth to water in each well. Values for $\mathrm{W}$ were determined at a calibration laboratory at the Nevada Test Site, and values for $S$ were determined by the U.S. Geological Survey and are estimated to be accurate to 7 percent (Tucci, O'Brien, and Burkhardt, 1996, p. 7). The manufacturer provides values for the reference tension $(\mathrm{K})$ at the time of purchase. Different mechanical stretch corrections are shown in figure 3 for different plumb bob weights on Chain \#3. If the plumb bob weight is less than the reference tension during manufacture, then Chain \#3 contracts and a negative mechanical stretch correction is applied until the weight of the apparent length of Chain \#3 and the plumb bob exceeds the reference tension. 


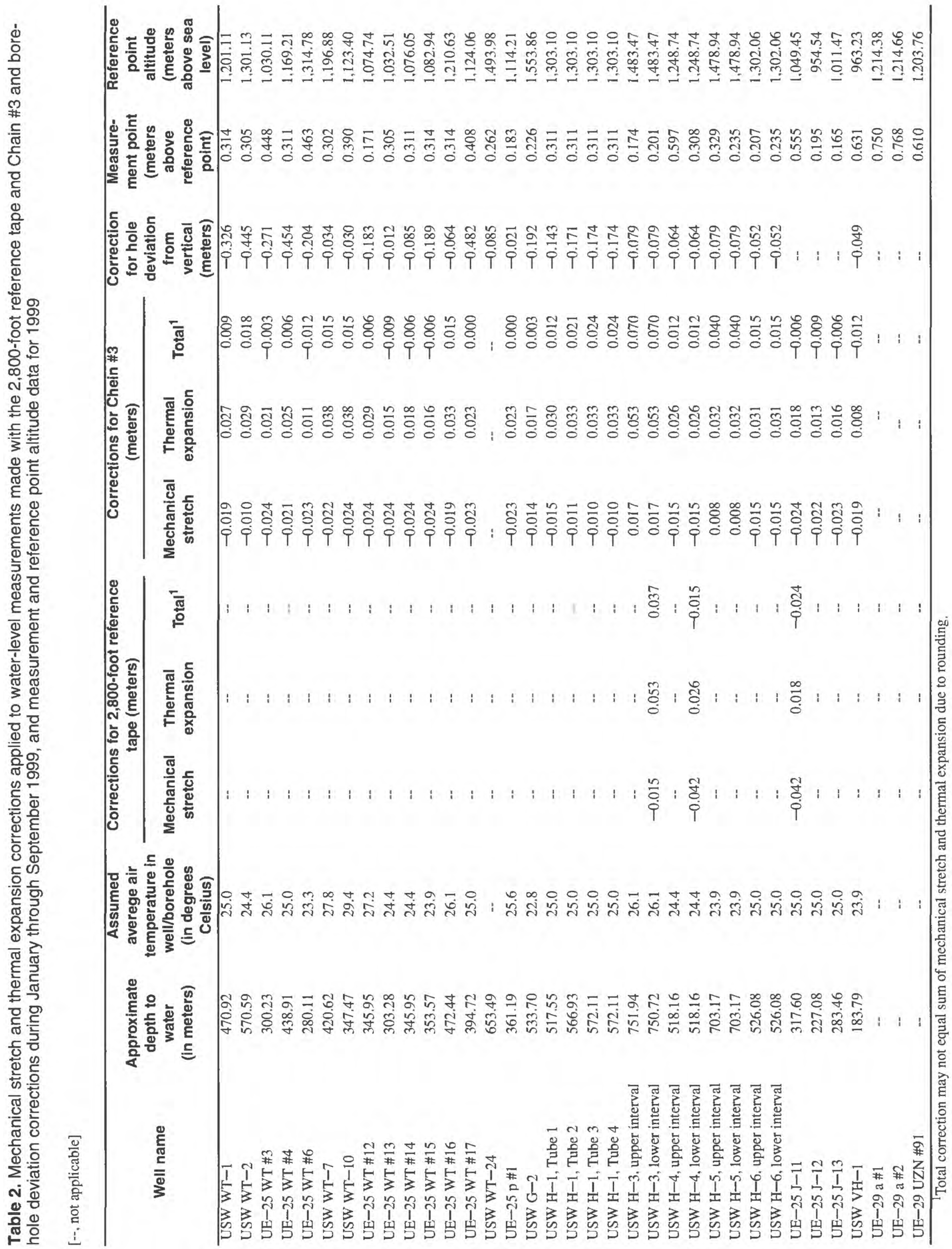




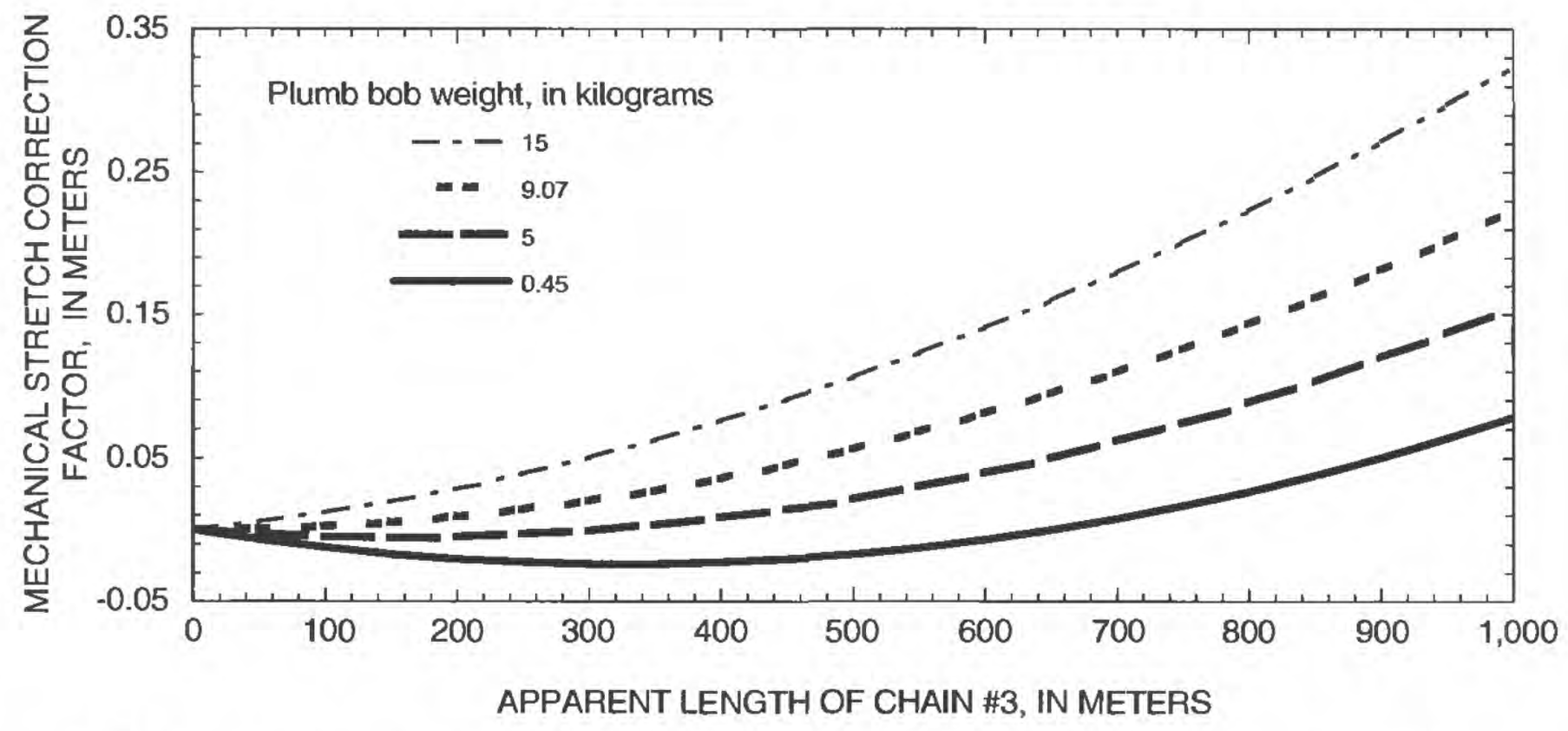

Figure 3. Mechanical stretch correction factors for Chain \#3 with different plumb bob weights.

\section{Thermal Expansion Correction}

Thermal expansion of a steel tape occurs because of temperature changes. The calculated correction for thermal expansion for steel tapes is based on manufacturer specifications for thermal expansion coefficients and on average hole temperatures calculated from temperature profiles in wells and boreholes at Yucca Mountain (Garber and Koopman, 1968, p. 3-6; Sass and Lachenbruch; 1982, Robison and others, 1988, p. 8 and 14; Tucci, O'Brien, and Burkhardt, 1996, p. 6). Corrections for January through September were based on approximate depthto-water values (table 2). The correction ranged from +0.008 to $+0.053 \mathrm{~m}$ (table 2). October through December corrections were based on mean apparent depth-to-water values from the individual measurements.

Correction for thermal expansion of the tape is given by:

$$
E=(D-R) T L,
$$

where

$\mathrm{E}$ is the correction, in meters;

$\mathrm{D}$ is the assumed average air temperature in the well or borehole, in degrees Celsius;

$\mathrm{R}$ is the reference temperature during manufacture, in degrees Celsius;

$\mathrm{T}$ is the thermal expansion coefficient. in meters per meter-degree Celsius; and

$\mathrm{L}$ is the apparent length of the tape, in meters.

Equation 2 differs from that of Garber and Koopman $(1968$, p. 4). The correction for thermal expansion in their report was subtracted from the measured depth to water when it should have been added (J.H. Robison, U.S. Geological Survey, written commun., 1985). Thermal expansion corrections for Chain \#3 for different borehole temperatures are shown in figure 4 . If the borehole temperature is less than the reference temperature during manufacture, then Chain \#3 contracts and a negative correction factor is applied. If the temperature is the same as the reference temperature, then no correction is applied. If the temperature is greater than the reference temperature, then Chain \#3 expands and a positive correction factor is applied. When Chain \#3 expands in a borehole, the depth-to-water distance is more than indicated by the reading at the land surface, and a positive correction is needed for the "true" depth to water.

The tape corrections, which include mechanical stretch and thermal expansion, and average air temperature in the well, are given in table 2 . The total correction for the 2,800-foot reference tape and Chain \#3 may not equal the sum of the mechanical stretch and thermal expansion corrections due to rounding. Approximate depth to water is analogous to apparent length of the tape, $\mathrm{L}$, in equations 1 and 2 . The tapedependent variables for equations 1 and 2 are defined for each tape in table 3.

\section{Multiconductor Cable Unit Calibration Correction}

The MSMCCU was calibrated to the 2,800-foot reference tape in August 1998, August 1999, October 1999, and June 2000. The calibration results indicated that depth-to-water measurements made with the MSMCCU require a calibration correction for deter- 


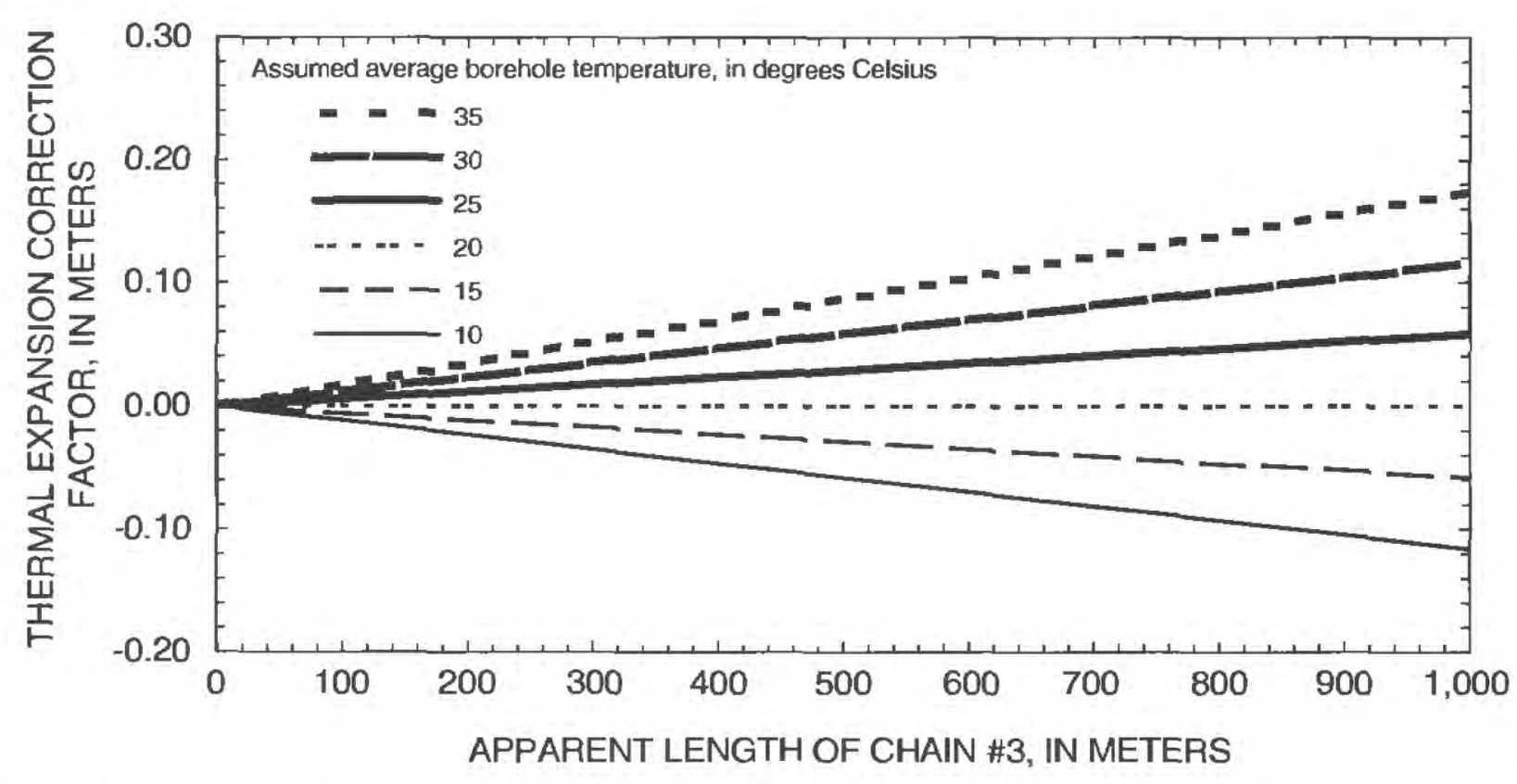

Figure 4. Thermal expansion correction factors for Chain \#3 with different assumed average borehole temperature.

mination of the water-level altitude (fig. 5). Three of the calibrations were used to correct 1999 depth-towater measurements.

Depth-to-water measurements for January through June were corrected using the results from the August 1998 calibration. The August 1998 calibration results defined a linear relation between the apparent depth to water and a calibration correction factor. The August 1998 calibration correction factor function was used directly from January through June.

Depth-to-water measurements for July through September were corrected using the results from the August 1999 calibration. During the period June through July an electronic drift was noticed in the MSMCCU electronic depth-measuring equipment. The results from the August 1999 calibration were applied backward in time for the July depth-to-water measurements. No closing calibration for this period is available because the cable was damaged during depth-to-water measurements in September and a closing calibration could not be performed.

Depth-to-water measurements for October through December were corrected using the results from the October 1999 calibration. The closing calibration for this period was made in June 2000. The two different correction factor functions were close enough to the repeatability error of 0.50 foot for the cable unit that the October 1999 calibration correction factor function was used directly for the period. Since no known activity could be determined to cause the change in calibration correction factors, it was decided not to perform a time-weighted correction between the two calibrations.

\section{Borehole Deviation Correction}

In addition to the corrections for mechanical stretch, thermal expansion, and equipment calibration if needed, corrections must also be made for boreholes

Table 3. Mechanical stretch and thermal expansion equation variable values for the 2,800-foot reference steel tape and Chain \#3

\begin{tabular}{lcc}
\hline \multicolumn{1}{c}{ Variable } & $\begin{array}{c}\text { 2,800-foot refer- } \\
\text { ence steel tape }\end{array}$ & Chain \#3 \\
\hline $\mathrm{W}$ is the unit weight of the tape, in kilograms per meter & $2.08 \times 10^{-2}$ & $2.65 \times 10^{-2}$ \\
$\mathrm{~S}$ is the stretch coefficient, in meters per meter-kilogram & $2.48 \times 10^{-5}$ & $1.69 \times 10^{-5}$ \\
$\mathrm{P}$ is the weight of plumb bob, in kilograms & 0.45 & 0.45 \\
$\mathrm{~K}$ is the reference tension during manufacture, in kilograms & 9.07 & 9.07 \\
$\mathrm{R}$ is the reference temperature during manufacture, in degrees Celsius & 20 & 20 \\
$\mathrm{~T}$ is the thermal expansion coefficient in meters per meter-degree Celsius & $1.16 \times 10^{-5}$ & $1.16 \times 10^{-5}$ \\
\hline
\end{tabular}




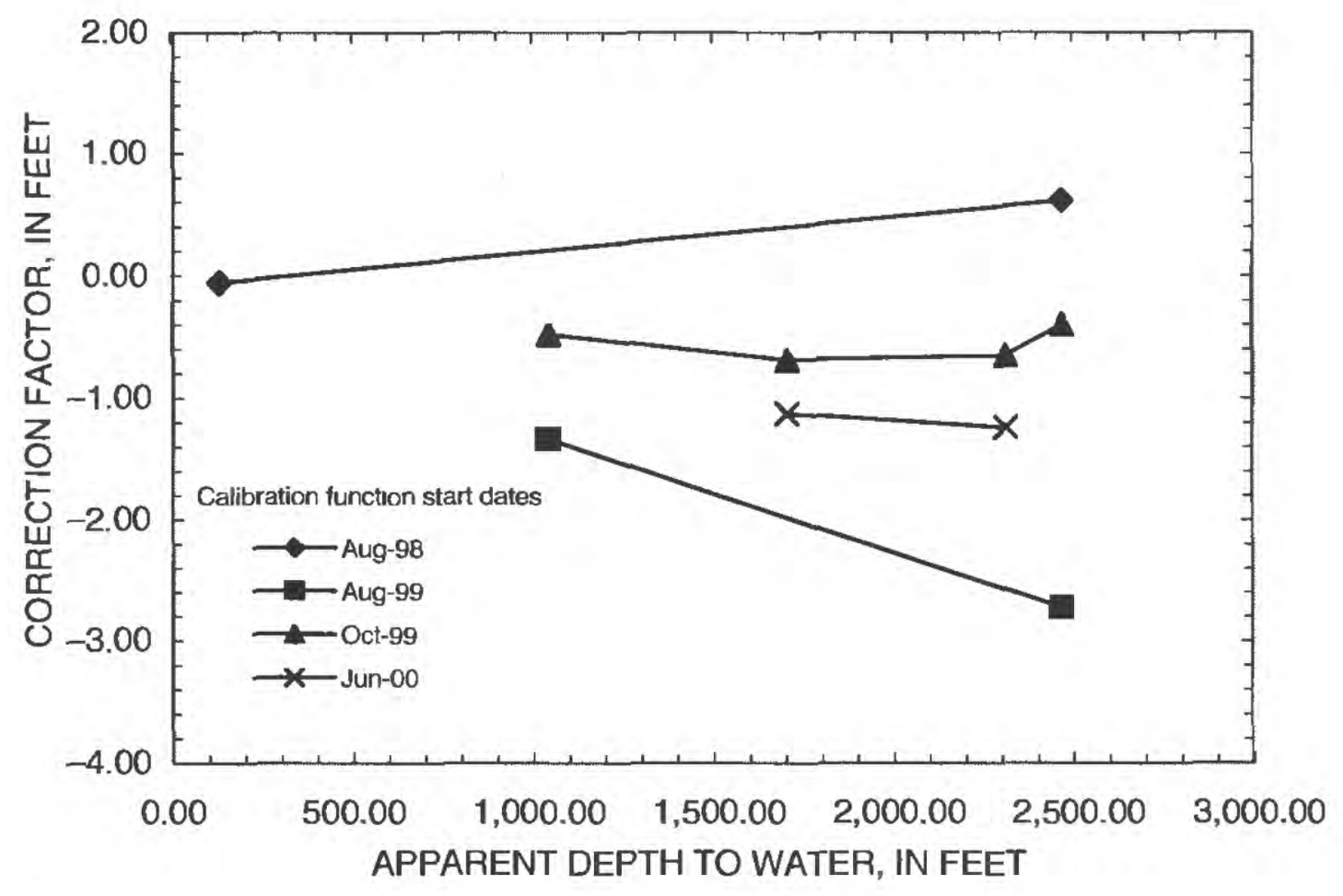

Figure 5. Mt. Sopris multiconductor cable unit calibration correction functions.

that are not vertical (borehole deviation). Gyroscopic surveys were made in all measured wells and boreholes except UE-25 J-11, UE-25 J-12, UE-25 J-13, UE-29 a \#1, and UE-29 UZN \#91. No borehole deviation corrections were made in these unsurveyed wells and boreholes. The gyroscopic surveys measured borehole deviation from vertical. The difference between measured depth and true vertical depth is the borehole deviation, or borehole correction. Corrections range from -0.012 to $-0.482 \mathrm{~m}$ (table 2 ). No borehole deviation correction was applied to UE-29 a \#2 because the measurement equipment hangs in the borehole vertically down to the shallow water level, less than 100 feet.
The gyroscopic surveys collected data at 50-foot intervals on the way into the borehole and at 50-foot intervals on the way out of the borehole, but at different depths. The results were combined and a 25-foot-interval gyroscopic survey for the borehole was developed. The combined gyroscopic survey results converted to metric units for borehole UE-25 WT \#17 are presented in figure 6. Apparent depth-towater measurements are corrected using the borehole deviation correction. For depths between the gyroscopic survey 25 -foot-interval data points, a linear interpolation is performed to compute the applied borehole deviation correction. Water level borehole deviation corrections from January through September

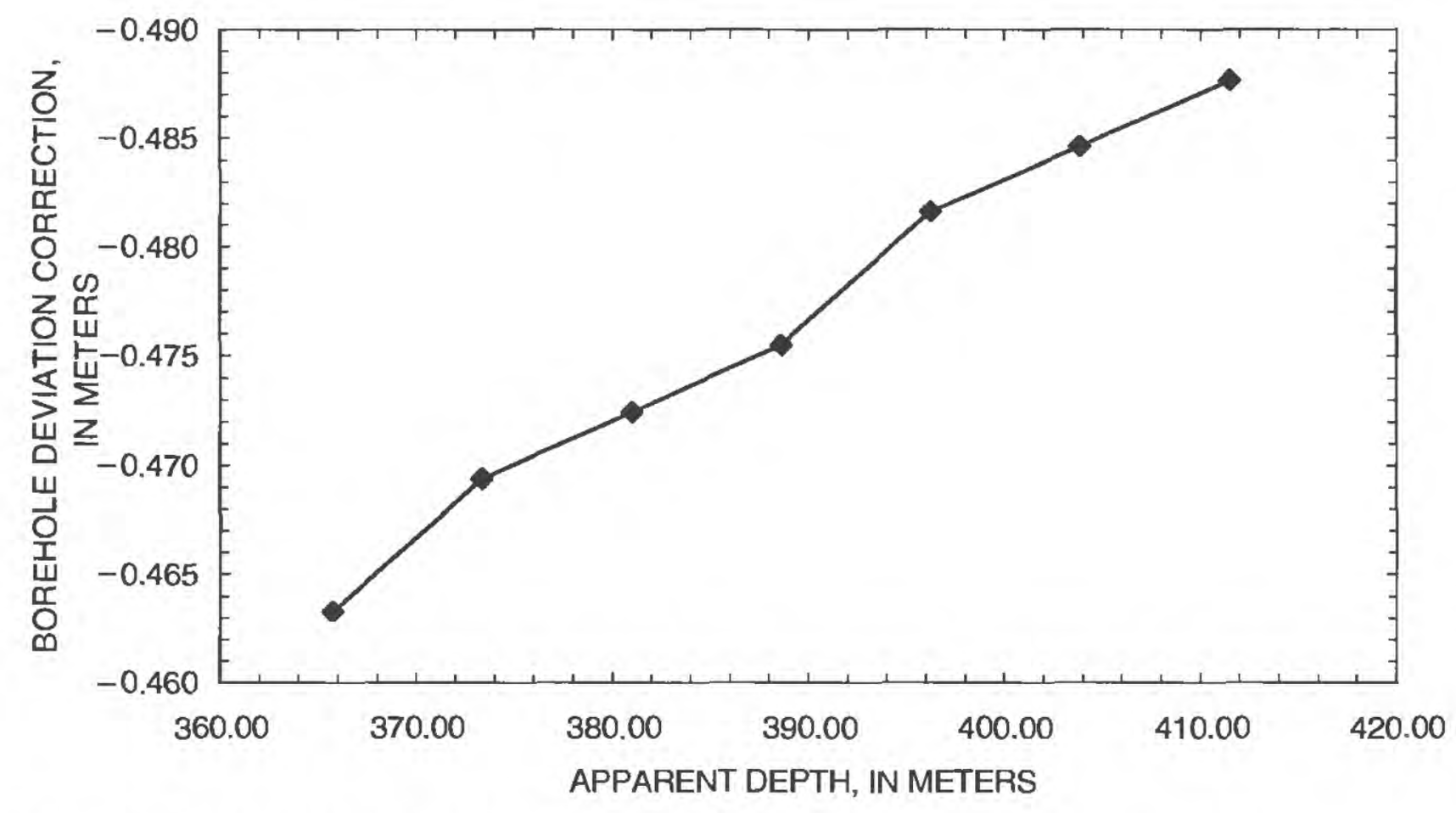

Figure 6. Borehole deviation correction for borehole UE-25 WT\#17. 
were computed based on an approximate depth to water (table 2). The October through December waterlevel borehole deviation corrections were computed individually based on the apparent depth to water for each measurement.

\section{Water-Level Altitudes}

Water-level altitudes are computed by subtracting the corrected depth to water below the reference point from the altitude of the reference point. The reference point generally is a metal tag on the well or borehole casing located near the land surface or some other identifiable feature. The measurement point for a well or borehole, at the top of the access tube (monitoring tube) or the top of the casing, is at some distance above the reference point, and the height of the measurement point is subtracted from the apparent depth to water as part of the process to compute the corrected depth to water. Reference-point and measurement-point values for all wells and boreholes are listed in table 2 and are described in the individual "Well and Borehole Data and Water Levels" sections. Most of the water-level altitudes in this report are based on a survey of the water-level monitoring network reference points made in late 1984 by the U.S. Geological Survey National Mapping Division (Merle E. Southern, U.S. Geological Survey, written commun., 1985). Others are based on surveys conducted by other Yucca Mountain Project participants for the Department of Energy.

\section{Example Water-Level Altitude Computations}

Three example water-level altitude computations are presented to illustrate how the different corrections and adjustments are made. At least two measurements of the depth to water are made and averaged during each visit to the well or borehole, and the appropriate corrections are applied after taking the mean of the depth-to-water measurements.

\section{Example 1: Chain \#3}

An example measurement for borehole USW WT-1 for May 5, 1999, is presented to illustrate a computation made to derive the water-level altitude with a reeled steel tape. The units of measurement for a steel tape are feet. All depth-to-water measurements are recorded to the nearest 0.01 foot and later converted to meters. The computed water-level altitude is the value reported in the section "Well and
Borehole Data and Water Levels." Additional depthto-water measurements are made only if the two measured depths differ by more than 1 part in 10,000 (for example, $0.15 \mathrm{ft}$ for a 1,500-foot measurement) for measurements of more than 1,000 feet, or more than 0.1 foot for measurements less than 1,000 feet. The depth-to-water measurement on May 5, 1999, at borehole USW WT-1 was made with Chain \#3. The HELD is the indicated footage on the tape when it is held at the measuring point during a measurement, and CUT is the footage of tape that is wetted during its submersion in the water. The difference between HELD and CUT is the apparent depth to water below the measuring point.

The measurements and corrections for borehole USW WT-1 on May 5, 1999, were:

\begin{tabular}{|c|c|c|c|}
\hline Reading & $\begin{array}{l}\text { Measure- } \\
\text { ment } 1\end{array}$ & $\begin{array}{l}\text { Measure- } \\
\text { ment } 2\end{array}$ & $\begin{array}{c}\text { Mean } \\
\text { measure- } \\
\text { ment }\end{array}$ \\
\hline HELD (ft) & $1,553.00$ & $1,554.00$ & \\
\hline CUT (ft) & -6.15 & -7.13 & \\
\hline Apparent depth to water (ft) & $1,546.85$ & $1,546.87$ & \\
\hline $\begin{array}{l}\text { Mean of two apparent } \\
\text { depths to water (ft) }\end{array}$ & & & $1,546.86$ \\
\hline $\begin{array}{l}\text { Apparent depth to water } \\
(1,546.86 \text { feet } x 0.3048 \\
\text { meter per foot })(\mathrm{m})\end{array}$ & & & 471.48 \\
\hline $\begin{array}{l}\text { Measurement point (m) } \\
\quad \text { (table 2) }\end{array}$ & & & -0.314 \\
\hline Tape correction (m) (table 2) & & & +0.009 \\
\hline $\begin{array}{l}\text { Correction for borehole } \\
\text { deviation from vertical } \\
\text { (m) (table 2) }\end{array}$ & & & -0.326 \\
\hline $\begin{array}{l}\text { Corrected depth to water } \\
\text { below reference point }(\mathrm{m})\end{array}$ & & & 470.85 \\
\hline \multicolumn{4}{|l|}{$\begin{array}{l}\text { Determination of water- } \\
\text { level altitude: }\end{array}$} \\
\hline $\begin{array}{l}\text { Reference point altitude (m) } \\
\text { (table } 2 \text { ) }\end{array}$ & & & $1,201 . I 1$ \\
\hline $\begin{array}{l}\text { Corrected depth to water } \\
\text { below reference point }(\mathrm{m})\end{array}$ & & & -470.85 \\
\hline Water-level altitude (m) & & & 730.26 \\
\hline
\end{tabular}

\section{Example 2: Mt. Sopris Multiconductor Cable Unit}

An example measurement for borehole USW WT-24 for September 23, 1999, is presented to illustrate a computation made to derive the water-level altitude with a cable unit. The units of measurement for the MSMCCU are feet. All depth-to-water measurements are recorded to the nearest 0.01 foot and later 
converted to meters. The computed water-level altitude is the value reported in the section "Well and Borehole Data and Water Levels." Additional depthto-water measurements are made only if the two measured depths differ by more than 0.5 foot.

The IN is the indicated footage on the cable unit when the probe is at the water surface in the borehole during a measurement, and OUT is the indicated footage on the cable unit when the probe is removed from the borehole and placed at the measurement point altitude. The difference between IN and OUT is the apparent depth to water below the measurement point.

The measurements and corrections for borehole USW WT-24 on September 23, 1999, were:

\begin{tabular}{|c|c|c|c|}
\hline Reading & $\begin{array}{l}\text { Measure- } \\
\text { ment } 1\end{array}$ & $\begin{array}{l}\text { Measure- } \\
\text { ment } 2\end{array}$ & $\begin{array}{l}\text { Mean } \\
\text { Measure- } \\
\text { ment }\end{array}$ \\
\hline IN (ft) & $2,147.42$ & 2.147 .45 & \\
\hline OUT (ft) & -0.69 & -0.68 & \\
\hline Apparent depth to water (ft) & $2,146.73$ & $2,146.77$ & \\
\hline $\begin{array}{l}\text { Mean of two apparent depths to } \\
\text { water ( } \mathrm{ft} \text { ) }\end{array}$ & & & $2,146.75$ \\
\hline $\begin{array}{l}\text { Apparent depth to water } \\
\qquad(2,146.75 \text { feet } x 0.3048 \\
\text { meter per foot) }(\mathrm{m})\end{array}$ & & & 654.33 \\
\hline Measurement point (m) (table 2) & & & -0.262 \\
\hline $\begin{array}{l}\text { Cable unit correction (m) (figure } \\
\text { 5) }\end{array}$ & & & -0.735 \\
\hline $\begin{array}{l}\text { Correction for borehole } \\
\text { deviation from vertical (m) } \\
\text { (table 2) }\end{array}$ & & & -0.085 \\
\hline $\begin{array}{l}\text { Corrected depth to water below } \\
\text { reference point }(\mathrm{m})\end{array}$ & & & 653.25 \\
\hline \multicolumn{4}{|l|}{$\begin{array}{l}\text { Determination of water-level } \\
\text { altitude: }\end{array}$} \\
\hline $\begin{array}{l}\text { Reference point altitude }(\mathrm{m}) \\
\quad \text { (table } 2)\end{array}$ & & & $1,493.98$ \\
\hline $\begin{array}{l}\text { Corrected depth to water below } \\
\text { reference point }(\mathrm{m})\end{array}$ & & & -653.25 \\
\hline Water-level altitude (m) & & & 840.73 \\
\hline
\end{tabular}

[ft, foot; $\mathrm{m}$, meter]

\section{Example 3: Hand-held add steel tape:}

An example measurement for borehole UE-29 a \#1 for May 4, 1999, is presented to illustrate a computation made to derive the water-level altitude with a hand-held steel tape. The units of measurement for a steel tape are feet. All depth-to-water measurements are recorded to the nearest 0.01 foot and later converted to meters. The computed water-level altitude is the value reported in the section "Well and Borehole Data and Water Levels". Additional depthto-water measurements are made only if the two measured depths differ by more than 0.05 foot.

The depth-to-water measurement on May 4, 1999, at borehole UE-29 a \#1 was made with STA-1. The HELD is the indicated footage on the tape when it is held at the measuring point during a measurement, and CUT is the footage of tape that is wetted during its submersion in the water. The CUT with the STA-1 is a negative number. The difference between HELD and CUT is the apparent depth to water below the measuring point.

The measurements and corrections for borehole UE-29 a \#1 on May 4, 1999, were:

\begin{tabular}{|c|c|c|c|}
\hline Reading & $\begin{array}{l}\text { Measure- } \\
\text { ment } 1\end{array}$ & $\begin{array}{l}\text { Measure- } \\
\text { ment } 2\end{array}$ & $\begin{array}{l}\text { Mean } \\
\text { Measure- } \\
\text { ment }\end{array}$ \\
\hline HELD (ft) & 88.00 & 88.00 & \\
\hline CUT (ft) & +0.88 & +0.88 & \\
\hline Apparent depth to water (ft) & 88.88 & 88.88 & \\
\hline $\begin{array}{l}\text { Mean of two apparent depths to } \\
\text { water (ft) }\end{array}$ & & & 88.88 \\
\hline $\begin{array}{l}\text { Apparent depth to water }(88.88 \text { feet } \\
\times 0.3048 \text { meter per foot) }(\mathrm{m})\end{array}$ & & & 27.09 \\
\hline Measurement point (m) (table 2) & & & -0.75 \\
\hline $\begin{array}{l}\text { Tape correction, not applicable (m) } \\
\text { (table 2) }\end{array}$ & & & 0.00 \\
\hline $\begin{array}{l}\text { Correction for borehole deviation } \\
\text { from vertical, not applicable (m) } \\
\text { (table 2) }\end{array}$ & & & 0.00 \\
\hline $\begin{array}{l}\text { Corrected depth to water below } \\
\text { reference point }(\mathrm{m})\end{array}$ & & & 26.34 \\
\hline \multicolumn{4}{|l|}{$\begin{array}{l}\text { Determination of water-level alti- } \\
\text { tude: }\end{array}$} \\
\hline $\begin{array}{l}\text { Reference point altitude (m) } \\
\quad \text { (table 2) }\end{array}$ & & & $1,214.38$ \\
\hline $\begin{array}{l}\text { Corrected depth to water below } \\
\text { reference point im) }\end{array}$ & & & -26.34 \\
\hline Water-level altitude ( $\mathrm{m}$ ) & & & $1,188.04$ \\
\hline
\end{tabular}

\section{Precision and Accuracy}

An analysis of precision and accuracy of field data was conducted for manual water-level measurements, which included all periodic measurements obtained during 1988-90 (Boucher, 1994a). The mean precision range of the 2,800-foot reference steel tape, based on 31 measurements, was $0.026 \mathrm{ft}$ (Boucher, 
1994a, p. 13) (because of changes in accuracy due to conversion to metric units and rounding of conversions, this discussion of precision and accuracy is in the units of the referenced report). The precision of Chain \#3 is not known but is believed to be the same or nearly the same as that of Chain \#2 because each chain has nearly the same physical characteristics and because they were identically constructed. The mean precision range of Chain \#2, based on 341 measurements, was $0.014 \mathrm{ft}$ (Boucher, 1994a, p. 13). Ninetyseven percent of all measurements obtained with the steel tapes were precise to within $0.05 \mathrm{ft}$ during 1988 90 (Boucher, 1994a, p. 17).

The overall accuracy of the computed waterlevel altitude depends on the individual accuracies of its computational components such as: (1) water-level measurement, (2) borehole correction, (3) height of the measuring point, (4) altitude of the reference point, and (5) the precision of the calibrated steel tapes. The total accuracy of measurements taken with the steel tapes during 1988-90 was estimated to be $0.36 \mathrm{ft}$, neglecting the accuracy of the borehole correction factors (Boucher, 1994a, p. 17). Accuracy of the borehole correction factors is indeterminate because documentation of the borehole-deviation surveys was inadequate to assess their accuracy and because no borehole-deviation data are available for wells UE-25 $\mathrm{J}-11$, UE-25 J-12, and UE-25 J-13. The unknown accuracy of the borehole corrections poses a problem in the calculation of overall accuracy values (Tucci, O'Brien, and Burkhardt, 1996, p. 9).

\section{Quality Assurance}

Water-level data for Yucca Mountain and vicinity may be used to assess the expected performance of a potential high-level nuclear-waste repository, and confidence in the reliability of the data used in such an assessment is required. A quality-assurance program has been implemented by the U.S. Geological Survey for the Yucca Mountain Project to support the reliability of the data and interpretations of the data.

\section{Onsite Procedures}

The quality-assurance program requires that water-level measurements be obtained by methods described by formal technical procedures. The technical procedures include calibrations to the equipment to ensure that the equipment is operating properly and that expected precision and accuracy are attained.
Data are recorded on paper at the well or borehole location. Data recorded include time and date of the visit, names of operators making the visit, identification of specific equipment used, and depth-to-water measurement data. In addition, the recorded data may include comments concerning factors that may be relevant to the collected data. such as discussion of problems with equipment or weather conditions during the depth-to-water measurement.

\section{Office Processing and Review}

The original field-note records were maintained throughout each calendar year at the onsite operations headquarters on the Nevada Test Site. The records were reviewed for completeness. The field-note records are transferred to water-level altitude worksheets, and any needed adjustments not done during onsite operations, such as tape and borehole-deviation corrections, are made at this time. The water-level altitude worksheets are completed at the operations headquarters on the Nevada Test Site. After independent data review and any needed adjustments, the field-note records and water-level altitude worksheets are transferred to the Yucca Mountain Project files.

\section{Qualified and Unqualified Data}

Data used by the Yucca Mountain Project are classified as either "qualified" or "unqualified." Qualified data are defined as data acquired or developed for the Yucca Mountain Project under a Nuclear Regulatory Commission-accepted quality-assurance plan or qualified in accordance with appropriate Yucca Mountain Project procedures. Depth-to-water measurements collected at Yucca Mountain after 1989 are obtained in accordance with approved Yucca Mountain Project quality-assurance procedures. However, measurement point altitudes and information used to calculate correction factors, such as borehole-deviation information, were obtained prior to the implementation of the accepted Yucca Mountain Project quality-assurance program in 1989. Therefore, the calculated water-level altitudes presented in previous reports were classified as unqualified data. During 1999 the previous waterlevel altitude data were found to be qualified (U.S. Department of Energy, 2000, written commun., MOL.20000331.0805). The 1999 water-level altitude computations use the same previously unqualified data, measurement point altitudes and borehole-deviation data and should be considered qualified. 


\section{WELL AND BOREHOLE DATA AND WATER LEVELS}

Most of the boreholes at the Yucca Mountain Project site were drilled in the 1980's. Some of the wells were drilled in the 1960's. Well and borehole locations have been measured by several surveys. This report lists the current accepted location from project records. Minor variations between the different surveys result in changes of the well/borehole location. These historical changes probably will not affect regional analysis, but may have an effect on smallscale investigations. Future investigations using the water-level altitude data should exercise care with the location data to use a consistent data set.

The different survey results also affect reference point elevations used to compute water-level altitudes. This report mainly uses the results from a survey conducted by the U.S. Geological Survey in the 1980's. This data set was chosen over newer altitude determinations of the land surface to maintain a consistent data set with previously published waterlevel altitudes.

Information on drilling histories, hole sizes, casings, geology, and other pertinent data have been taken from Yucca Mountain Project files and reports. This information is referenced for each well or borehole.

Water levels for the wells and boreholes were computed from the depth-to-water measurements, any appropriate corrections, and adjustments for determining the altitude. The maximum 1999 mean waterlevel altitude was $1,187.99 \mathrm{~m}$ above sea level for borehole UE-29 a \#1. This borehole is to the northeast of Yucca Mountain. The minimum 1999 mean waterlevel altitude was $727.96 \mathrm{~m}$ above sea level for well UE-25 J-12. This well is to the southeast of Yucca Mountain. These two sites measure water-table conditions in the Tertiary volcanic aquifer in the Yucca Mountain area. In the underlying Paleozoic carbonate aquifer, measured in borehole UE-25 p \#1, the 1999 mean water-level altitude was $752.93 \mathrm{~m}$ above sea level.

The 1999 mean water-level altitude rose for 24 intervals over 1998 values. The 1999 mean waterlevel altitude declined for three intervals over 1998 values. Eight intervals did not have mean water-level altitudes computed for both 1998 and 1999 and were not compared.

\section{Borehole USW WT-1}

\section{Borehole specifications}

1. Location and identification:

Nevada State Plane North American Datum of 1927 Central Zone Coordinates (meters): N 229,802; E 171,828 (U.S. Department of Energy, written commun., 1999, MO9907YMP99025.001)

Latitude and longitude: $36^{\circ} 49^{\prime} 16^{\prime \prime} \mathrm{N}$.; $116^{\circ} 26^{\prime} 56^{\prime \prime}$. (Converted from Nevada State Plane North American Datum of 1927 Central Zone Coordinates)

U.S. Geological Survey Site ID: 364916116265601 .

2. Drilling and casing information:

Borehole started: April 28, 1983 (Fenix \& Scisson, Inc., 1986a, p. 69).

Borehole completed: May 18, 1983 (Fenix \& Scisson. Inc., 1986a, p. 69).

Drilling method: Rotary, using rock bits and air, water, and soap-circulating medium; core obtained from bottom of the borehole (Robison, and others, 1988, p. 21 ).

Bit diameter, below land surface: 0 to $10.21 \mathrm{~m}$, $660.4 \mathrm{~mm} ; 10.21$ to $514.81 \mathrm{~m}, 222.25 \mathrm{~mm}$ (Fenix \& Scisson, Inc., 1986a, p. 69).

Casing, below land surface: Only surface casing in borehole, to a depth of $9.91 \mathrm{~m}$ (Fenix \& Scisson, Inc., 1986a, p. 69).

Total drilled depth: 514.81 m (Fenix \& Scisson, Inc., 1986a, p. 69).

3. Description of access tube and depth interval for measuring water levels:

62-mm-inside-diameter tubing (Robison and others. 1988, p. 21) that has a 3.66-m-long well screen on the bottom; tubing and attached screen extend from land surface to a depth of 507.49 m (Fenix \& Scisson, Inc., 1986a, p. 69); saturated interval of the borehole is within the Calico Hills Formation and Bullfrog Tuff of the Crater Flat Group (Robison and others, 1988, p. 21). Stratigraphic nomenclature presented by Robison revised to agree with stratigraphic nomenclature in Sawyer and others (1994, p. 1305).

4. Information for calculating water-level altitude:

Reference point: Top of metal tag on well casing, altitude $1,201.11 \mathrm{~m}$ (surveyed by U.S. 
Geological Survey in 1984; Merle E. Southern, National Mapping Division, U.S. Geological Survey, written commun., 1985).

Measurement point: Top of access tube, $0.314 \mathrm{~m}$ above reference point.

Depth correction for borehole deviation from vertical: Computed from borehole deviation survey dated May 19, 1983 (U.S. Department of Energy, written commun., 1994, MOL. 19950516.0146); $-0.326 \mathrm{~m}$, based on approximate depth to water of $471 \mathrm{~m}(1992$ data) or interpolated directly from borehole deviation survey for the October through December 1999 measurements.

Borehole USW WT-1 was measured monthly during 1999 with Chain \#3. Water levels fluctuated within a $0.10 \mathrm{~m}$ range during 1999 (fig. 7) with the lowest water level during this period being $730.24 \mathrm{~m}$ above sea level (02-10-99) and the highest water level being $730.34 \mathrm{~m}$ above sea level (12-02-99) (table 4). The mean water-level altitude of the 1999 data was $730.31 \mathrm{~m}$ above sea level and was within the range of previous annual mean water-level altitudes from 1985 to 1998 (fig. 8). Annual mean water-level altitudes have been rising since 1997.

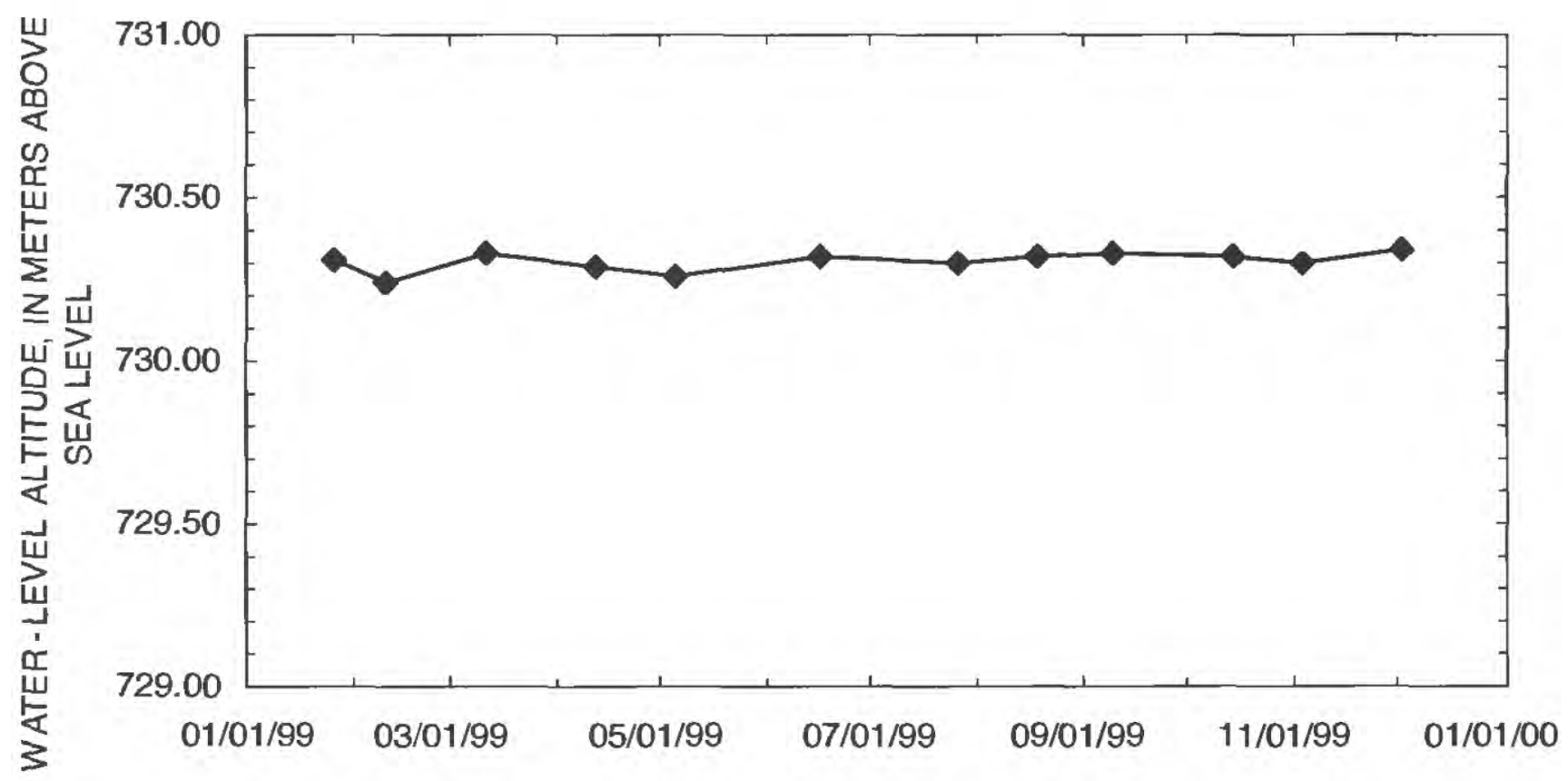

Figure 7. Water-level altitudes for borehole USW WT-1 during 1999.

Table 4. Measured water-level altitudes, 1999, for borehole USW WT-1

\begin{tabular}{cccc}
\hline Date & Time & $\begin{array}{c}\text { Water-level altitude } \\
\text { (meters above sea } \\
\text { level) }\end{array}$ & $\begin{array}{c}\text { Equipment } \\
\text { used to } \\
\text { measure water } \\
\text { level }\end{array}$ \\
\hline $01-26-99$ & 1107 & 730.31 & Chain \#3 \\
$02-10-99$ & 1358 & 730.24 & Chain \#3 \\
$03-11-99$ & 1531 & 730.33 & Chain \#3 \\
$04-12-99$ & 1346 & 730.29 & Chain \#3 \\
$05-05-99$ & 1255 & 730.26 & Chain \#3 \\
$06-16-99$ & 1217 & 730.32 & Chain \#3 \\
$07-26-99$ & 1303 & 730.30 & Chain \#3 \\
$08-18-99$ & 1404 & 730.32 & Chain \#3 \\
$09-09-99$ & 1356 & 730.33 & Chain \#3 \\
$10-14-99 \cdot$ & 900 & 730.32 & Chain \#3 \\
$11-03-99$ & 1406 & 730.30 & Chain \#3 \\
$12-02-99$ & 1433 & 730.34 & Chain \#3 \\
\hline
\end{tabular}




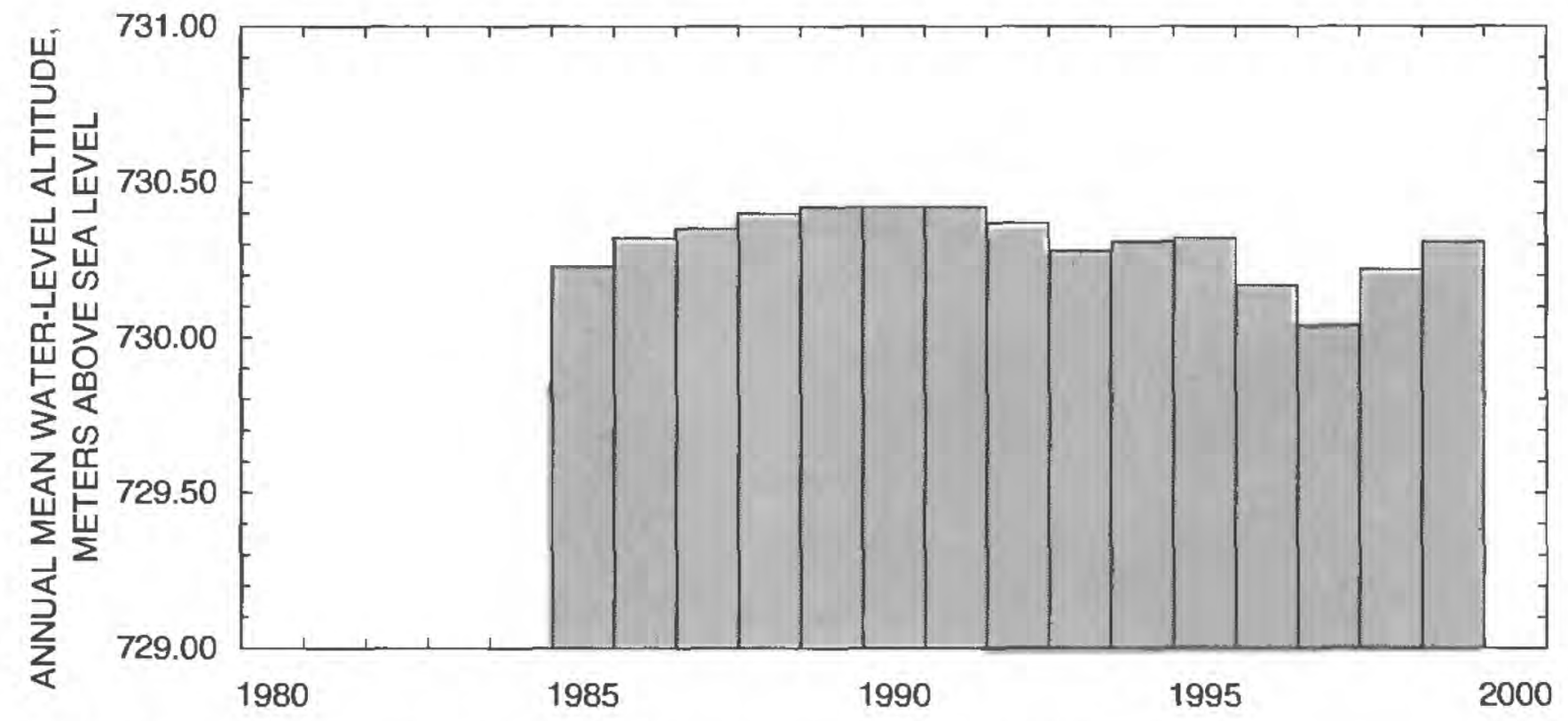

Figure 8. Annual mean water-level altitudes for borehole USW WT-1.

\section{Borehole USW WT-2}

\section{Borehole specifications}

\section{Location and identification:}

Nevada State Plane North American Datum of 1927 Central Zone Coordinates (meters): N 231,850; E 171,274 (U.S. Department of Energy, written commun., 1999, MO9907YMP99025.001)

Latitude and longitude: $36^{\circ} 50^{\prime} 23$ " $\mathrm{N}$.; $116^{\circ} 27^{\prime} 18^{\prime \prime}$ W. (Converted from Nevada State Plane North American Datum of 1927 Central Zone Coordinates)

U.S. Geological Survey Site ID: 365023116271801 .

2. Drilling and casing information:

Borehole started: July 8, 1983 (Fenix \& Scisson, Inc., 1986a, p. 75).

Borehole completed: July 16, 1983 (Fenix \& Scisson, Inc., 1986a, p. 75).

Drilling method: Rotary, using rock bits and airfoam circulating medium; core obtained from bottom of the borehole (Robison and others, 1988, p. 25).

Bit diameter, below land surface: 0 to $17.68 \mathrm{~m}$, $374.65 \mathrm{~mm} ; 17.68 \mathrm{~m}$ to $627.89 \mathrm{~m}, 222.25 \mathrm{~mm}$ (Fenix \& Scisson, Inc., 1986a, p. 75).

Casing, below land surface: Only surface casing in borehole, to a depth of $17.68 \mathrm{~m}$ (Fenix \& Scisson, Inc., 1986a, p. 75).

Total drilled depth: 627.89 m (Fenix \& Scisson, Inc., 1986a, p. 75).
3. Description of access tube and depth interval for measuring water levels:

62-mm-inside-diameter tubing (Robison and others, 1988 , p. 25) that has a $3.66-\mathrm{m}$-long well screen on bottom, extending from land surface to a depth of $621.79 \mathrm{~m}$ (Fenix \& Scisson, Inc., 1986a, p. 75); saturated interval of the borehole is within the Prow Pass Tuff of the Crater Flat Group (Robison and others, 1988, p. 25). Stratigraphic nomenclature presented by Robison revised to agree with stratigraphic nomenclature in Sawyer and others (1994, p. 1305).

4. Information for calculating water-level altitude:

Reference point: Top of metal tag on well casing; altitude 1,301.13 m (surveyed by U.S. Geological Survey in 1984; Merle E. Southern, National Mapping Division, U.S. Geological Survey, written commun., 1985).

Measurement point: Top of access tube, $0.305 \mathrm{~m}$ above reference point after December 8, 1993, $0.146 \mathrm{~m}$ above reference point between September 9, 1993, and December 8, 1993, and $0.311 \mathrm{~m}$ above reference point prior to September 9, 1993.

Depth correction for borehole deviation from vertical: Computed from borehole deviation survey dated January 11, 1994 (U.S. Department of Energy, written commun., 1994, TMUSWWT2000095.002); $-0.445 \mathrm{~m}$, based on approximate depth to water of $571 \mathrm{~m} \mathrm{(1992}$ data) or interpolated directly from borehole 
deviation survey for the October through

December 1999 measurements.

Borehole USW WT-2 was measured periodically during 1999 with Chain \#3. Water levels fluctuated within a 0.13 -m range during 1999 (fig. 9) with the lowest water level during this period being $730.48 \mathrm{~m}$ above sea level (01-14-99) and the highest water level being $730.61 \mathrm{~m}$ above sea level (10-06-99 and 12-10-99) (table 5). The mean water-level altitude of the 1999 data was $730.56 \mathrm{~m}$ above sea level and was within the range of previous annual mean water-level altitudes from 1985 to 1998 (fig. 10). Annual mean water-level altitudes have been rising since 1997.

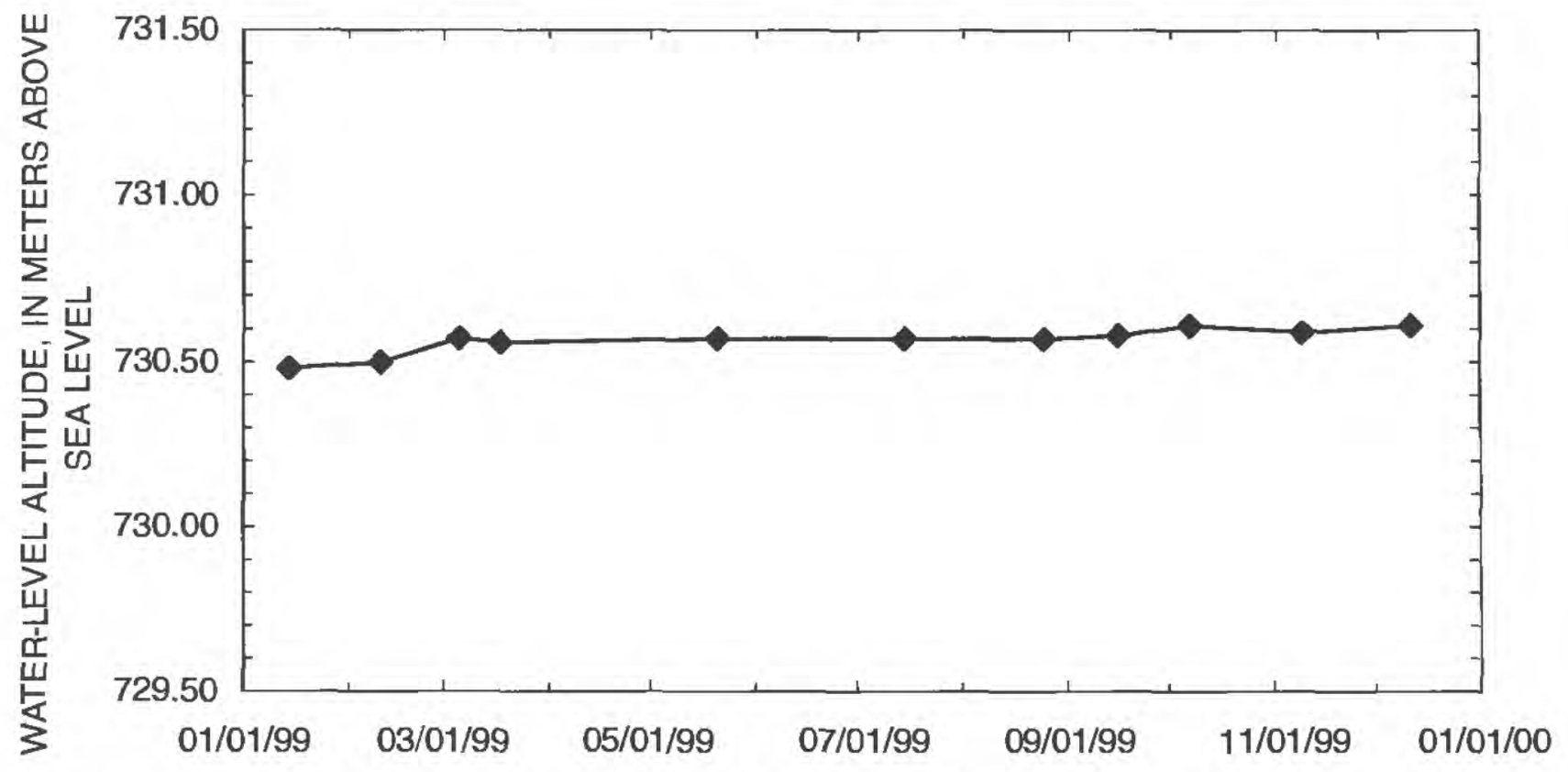

Figure 9. Water-level altitudes for borehole USW WT-2 during 1999.

Table 5. Measured water-level altitudes, 1999, for borehole USW WT-2

\begin{tabular}{cccc}
\hline Date & Time & $\begin{array}{c}\text { Water-level eltitude } \\
\text { (meters above sea } \\
\text { level) }\end{array}$ & $\begin{array}{c}\text { Equipment } \\
\text { used to } \\
\text { measure water } \\
\text { level }\end{array}$ \\
\hline $01-14-99$ & 1021 & 730.48 & Chain \#3 \\
$02-10-99$ & 1147 & 730.50 & Chain \#3 \\
$03-05-99$ & 910 & 730.57 & Chain \#3 \\
$03-17-99$ & 903 & 730.56 & Chain \#3 \\
$05-20-99$ & 1216 & 730.57 & Chain \#3 \\
$07-14-99$ & 1140 & 730.57 & Chain \#3 \\
$08-24-99$ & 1307 & 730.57 & Chain \#3 \\
$09-15-99$ & 823 & 730.58 & Chain \#3 \\
$10-06-99$ & 900 & 730.61 & Chain \#3 \\
$11-08-99$ & 1140 & 730.59 & Chain \#3 \\
$12-10-99$ & 1205 & 730.61 & Chain \#3 \\
\hline
\end{tabular}




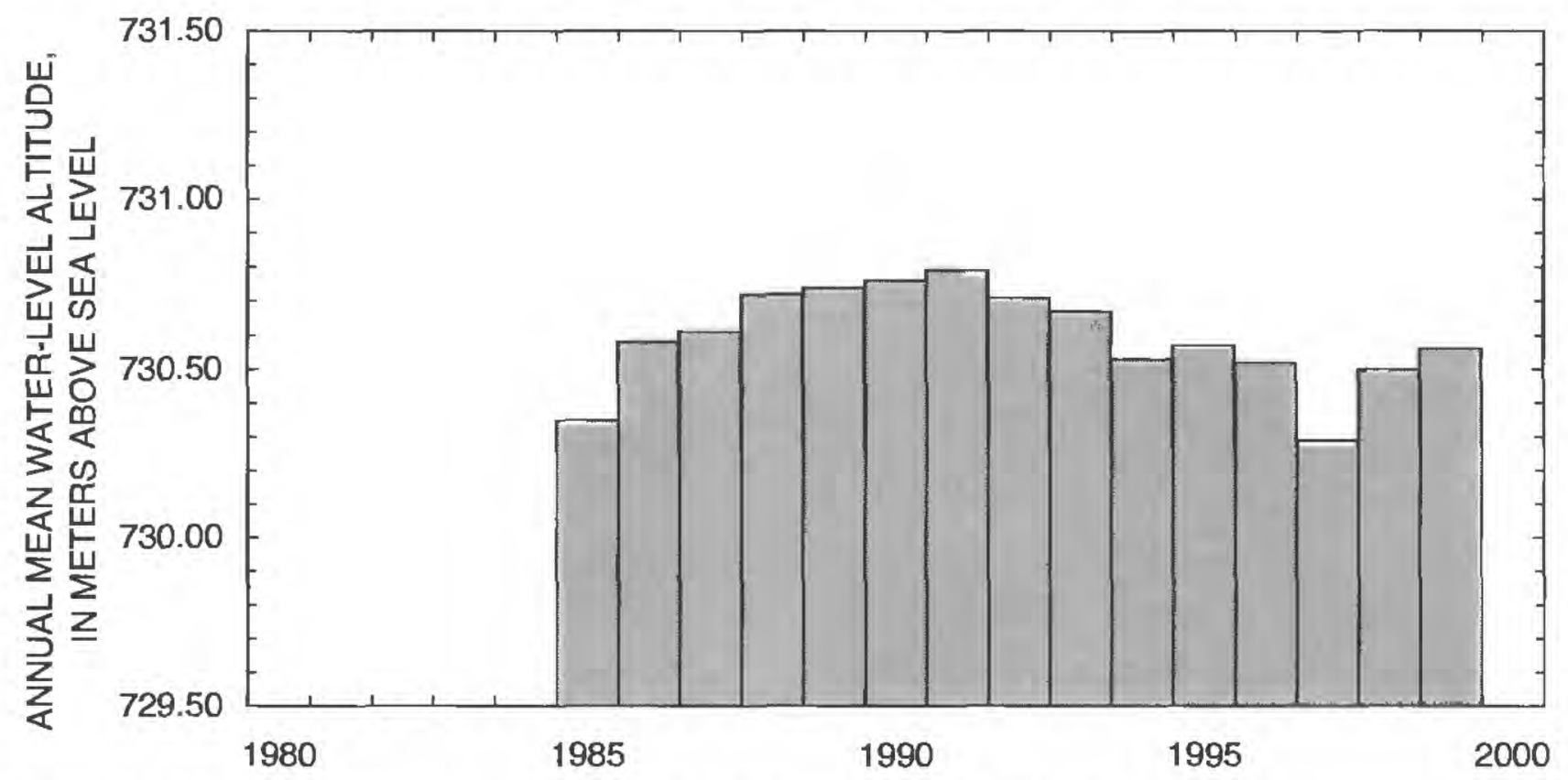

Figure 10. Annual mean-water level altitudes for borehole USW WT-2.

\section{Borehole UE-25 WT\#3}

\section{Borehole specifications}

1. Location and identification:

Nevada State Plane North American Datum of 1927 Central Zone Coordinates (meters): N 227,379; E 174,768 (U.S. Department of Energy, written commun., 1999. MO9907YMP99025.001)

Latitude and longitude: $36^{\circ} 47^{\prime} 57^{\prime \prime} \mathrm{N}$.; $116^{\circ} 24^{\prime} 58^{\prime \prime}$. (Converted from Nevada State Plane North American Datum of 1927 Central Zone Coordinates)

U.S. Geological Survey Site ID: 364757116245801 .

2. Drilling and casing information:

Borehole started: April 29, 1983 (Fenix \& Scisson, Inc., 1986a, p. 3).

Borehole completed: May 25, 1983 (Fenix \& Scisson, Inc., 1986a, p. 3).

Drilling method: Rotary, using rock bits and airfoam circulating medium; core obtained from bottom of the borehole (Robison and others, 1988 , p. 28).

Bit diameter, below land surface: 0 to $4.11 \mathrm{~m}$, $1,219.2 \mathrm{~mm} ; 4.11$ to $12.50 \mathrm{~m}, 374.65 \mathrm{~mm}$; $12.50 \mathrm{~m}$ to $348.08 \mathrm{~m}, 222.25 \mathrm{~mm}$ (Fenix \& Scisson, Inc., 1986a, p. 3).

Casing, below land surface: Only surface casing in borehole, to a depth of $12.19 \mathrm{~m}$ (Fenix \& Scisson, Inc., 1986a, p. 3).
Total drilled depth: 348.08 m (Fenix \& Scisson, Inc., 1986a, p. 3 ).

3. Description of access tube and depth interval for measuring water levels:

January 1, 1997-December 22, 1997: 62-mminside-diameter tubing (Robison and others, 1988 , p. 28) that has a $3.66-\mathrm{m}$-long well screen on bottom, extending from land surface to a depth of $342.90 \mathrm{~m}$ (Fenix \& Scisson, Inc., 1986a, p. 3).

December 22, 1997-July 22, 1998: Workover on borehole so water-quality sampling could be completed. Access tube removed from borehole and replaced during workover.

July 22, 1998: Access tube replaced in borehole: 61.7-mm-inside-diameter fiberglass tubing from 293.09 to $331.13 \mathrm{~m}$ below land surface. Fiberglass tubing slotted (screened) from 326.56 to $331.13 \mathrm{~m}$ below land surface. Bottom of fiberglass tubing is capped. Two drain holes are drilled into the cap. From $293.09 \mathrm{~m}$ to land surface access tube is $62.0-\mathrm{mm}$-insidediameter pipe tubing (U.S. Department of Energy, written commun., 1998, MOL.19980930.0313).

Saturated interval of the borehole is within the Bullfrog Tuff of the Crater Flat Group (Robison and others, 1988, p. 28). Stratigraphic nomenclature presented by Robison revised to agree with stratigraphic nomenclature in Sawyer and others (1994, p. 1305). 
4. Information for calculating water-level altitude:

Reference point: Top of metal tag on well casing; altitude $1,030.11 \mathrm{~m}$ (surveyed by U.S. Geological Survey in 1984; Merle E. Southern, National Mapping Division, U.S. Geological Survey, written commun., 1985).

Measurement point: Top of access tubing, $0.448 \mathrm{~m}$ above reference point.

Depth correction for borehole deviation from vertical: Computed from borehole deviation survey dated February 27, 1984 (U.S.

Department of Energy, written commun., MOL.19970211.0049); $-0.271 \mathrm{~m}$, based on approximate depth to water of $300 \mathrm{~m} \mathrm{(1992}$ data) or interpolated directly from borehole deviation survey for the October through December 1999 measurements.
Borehole UE-25 WT\#3 was measured periodically during 1999 with Chain \#3 and the MSMCCU. The MSMCCU was used because of concerns about salt from Chain \#3 influencing natural water quality. Chain \#3 was again used when chalk was used to determine were the cut occurred. Water levels fluctuated within a 0.36-m range during 1999 (fig. 11) with the lowest water level being $729.46 \mathrm{~m}$ above sea level (03-18-99) and the highest water level being $729.82 \mathrm{~m}$ above sea level (04-21-99) (table 6). The mean water-level altitude of the 1999 data was $729.68 \mathrm{~m}$ above sea level and was within the range of previous annual mean water-level altitudes from 1985 to 1997 (fig. 12). The 1999 annual mean water-level altitude was higher than the 1997 annual mean waterlevel altitude. Only one measurement was made in 1998 and no annual mean water-level altitude was determined.

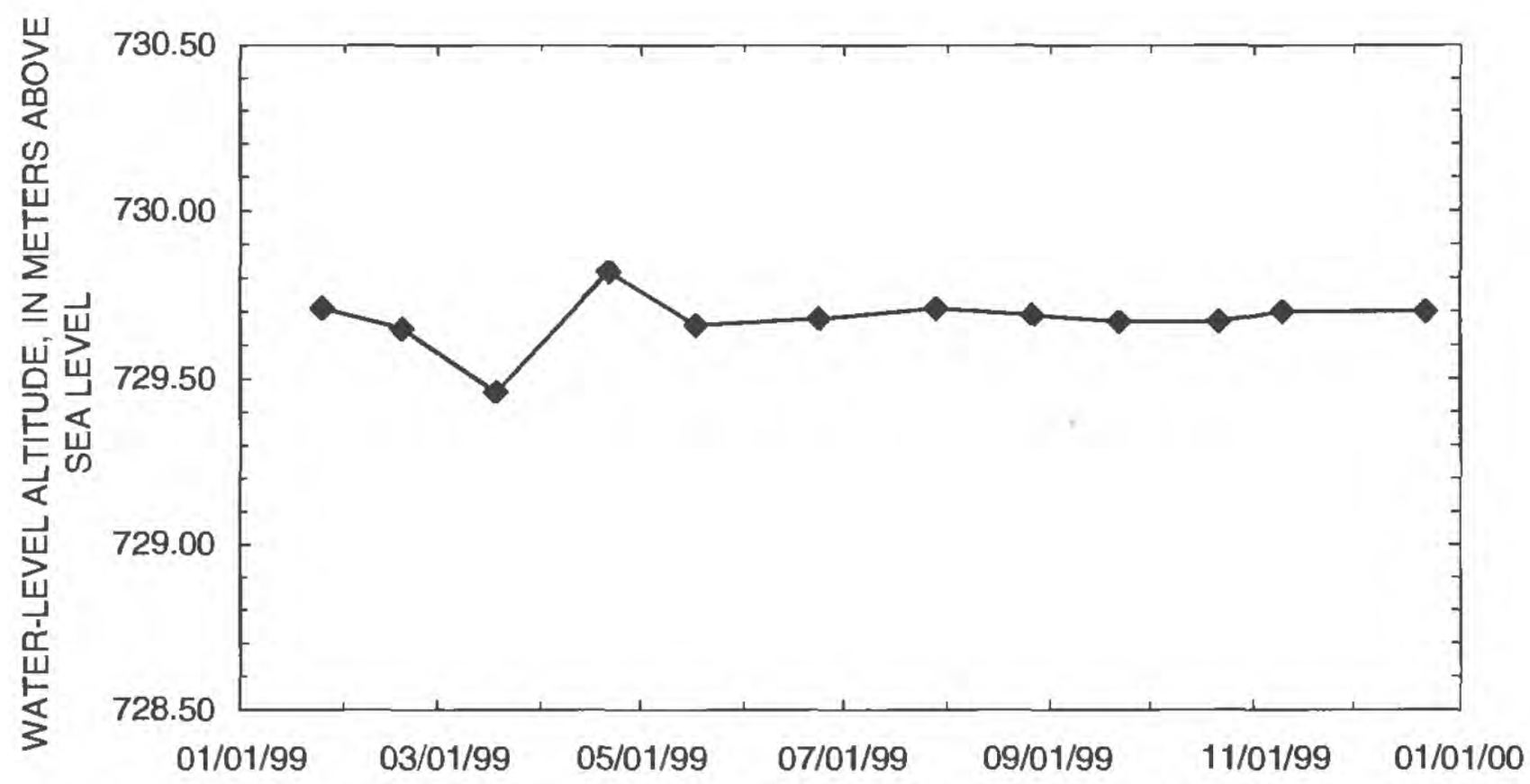

Figure 11. Water-level altitudes for borehole UE-25 WT \#3 during 1999.

Table 6. Measured water-level altitudes, 1999, for borehole UE-25 WT \#3

\begin{tabular}{cccc}
\hline Date & Time & $\begin{array}{c}\text { Water-level altitude } \\
\text { (meters above sea } \\
\text { level) }\end{array}$ & $\begin{array}{c}\text { Equipment } \\
\text { used to } \\
\text { measure water } \\
\text { level }\end{array}$ \\
\hline $01 / 25 / 99$ & 1532 & 729.71 & Chain \#3 \\
$02 / 18 / 99$ & 1036 & 729.65 & Chain \#3 \\
$03 / 18 / 99$ & 1052 & 729.46 & MSMCCU \\
$04 / 21 / 99$ & 1447 & 729.82 & Chain \#3 \\
$05 / 17 / 99$ & 1150 & 729.66 & Chain \#3 \\
$06 / 23 / 99$ & 908 & 729.68 & Chain \#3 \\
$07 / 28 / 99$ & 1456 & 729.71 & Chain \#3 \\
$08 / 26 / 99$ & 1417 & 729.69 & Chain \#3 \\
$09 / 21 / 99$ & 1243 & 729.67 & Chain \#3 \\
$10 / 21 / 99$ & 942 & 729.67 & Chain \#3 \\
$11 / 09 / 99$ & 1551 & 729.70 & Chain \#3 \\
$12 / 22 / 99$ & 1147 & 729.70 & Chain \#3 \\
\hline
\end{tabular}




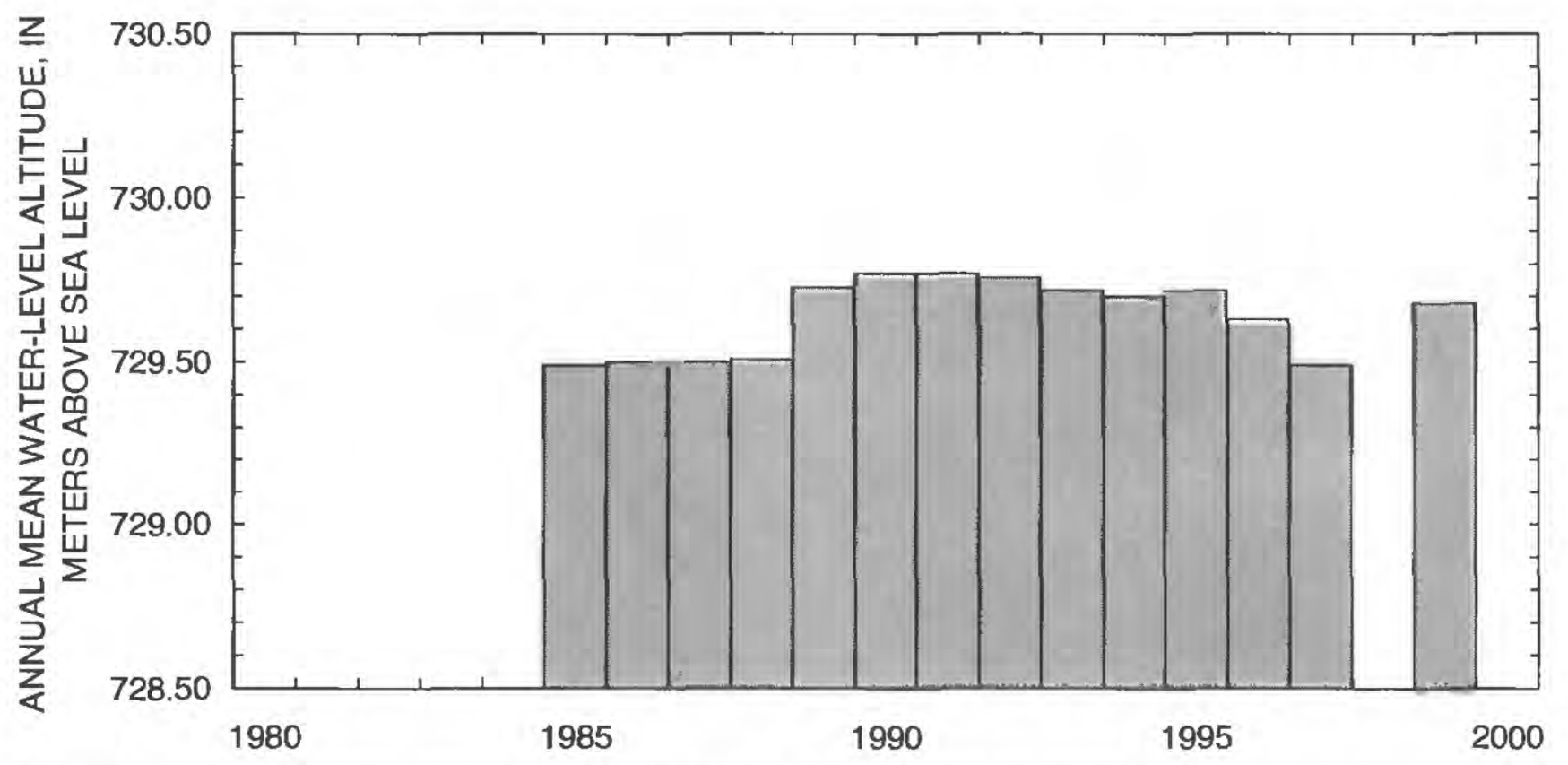

Figure 12. Annual mean water-level altitudes for borehole UE-25 WT \#3.

\section{Borehole UE-25 WT\#4}

\section{Borehole specifications}

1. Location and identification:

Nevada State Plane North American Datum of 1927 Central Zone Coordinates (meters): N 234,242; E 173,138 (U.S. Department of Energy, written commun., 1999, MO9907YMP99025.001)

Latitude and longitude: $36^{\circ} 51^{\prime} 40^{\prime \prime} \mathrm{N}$.; $116^{\circ} 26^{\prime} 03^{\prime \prime}$. (Converted from Nevada State Plane North American Datum of 1927 Central Zone Coordinates)

U.S. Geological Survey Site ID: 365140116260301.

2. Drilling and casing information:

Borehole started: May 28. 1983 (Fenix \& Scisson, Inc., 1986a, p. 9).

Borehole completed: June 6, 1983 (Fenix \& Scisson, Inc., 1986a, p. 9).

Drilling method: Rotary, using rock bits and airfoam circulating medium; core obtained from bottom of the borehole (Robison and others, 1988, p. 31).

Bit diameter, below land surface: 0 to $15.24 \mathrm{~m}$, $374.65 \mathrm{~mm} ; 15.24 \mathrm{~m}$ to $481.58 \mathrm{~m}, 222.25 \mathrm{~mm}$ (Fenix \& Scisson, Inc., 1986a, p. 9).

Casing, below land surface: Only surface casing in borehole, to a depth of $14.63 \mathrm{~m}$ (Fenix \& Scisson, Inc., 1986a, p. 9).

Total drilled depth: 481.58 m (Fenix \& Scisson, Inc., 1986a, p. 9).
3. Description of access tube and depth interval for measuring water levels:

62-mm-inside-diameter tubing (Robison and others, 1988, p. 31 ) that has a $3.66-\mathrm{m}-$ long well screen on the bottom; tubing and attached screen extend from land surface to a depth of 477.62 m (Fenix \& Scisson, Inc., 1986a, p. 9); saturated interval of the borehole is within the Calico Hills Formation (Robison and others, 1988, p. 31). Stratigraphic nomenclature presented by Robison revised to agree with stratigraphic nomenclature in Sawyer and others (1994, p. 1305).

4. Information for calculating water-level altitude:

Reference point: Top of metal tag on well casing, altitude $1,169.21 \mathrm{~m}$ (surveyed by U.S. Geological Survey in 1984; Merle E. Southern, National Mapping Division, U.S. Geological Survey, written commun., 1985).

Measurement point: Top of access tube. $0.311 \mathrm{~m}$ above reference point.

Depth correction for borehole deviation from vertical: Computed from borehole deviation survey dated June 2, 1983 (U.S. Department of Energy, 1996, written commun., MOL.19961125.0012), $-0.454 \mathrm{~m}$, based on approximate depth to water of $439 \mathrm{~m}$ (1992 data) or interpolated directly from borehole deviation survey for the October through December 1999 measurements.

Borehole UE-25 WT\#4 was measured periodically during 1999 with Chain \#3. Water levels fluctu- 
ated within a $0.11-\mathrm{m}$ range during 1999 (fig. 13)

with the lowest water level being $730.78 \mathrm{~m}$ above sea level (10-12-99) and the highest water level being $730.89 \mathrm{~m}$ above sea level (02-04-99) (table 7).

The mean water-level altitude of the 1999 data was
$730.83 \mathrm{~m}$ above sea level and was within the range of previous annual mean water-level altitudes from 1985 to 1997 (fig. 14). Annual mean water-level altitudes have been rising since 1997 .

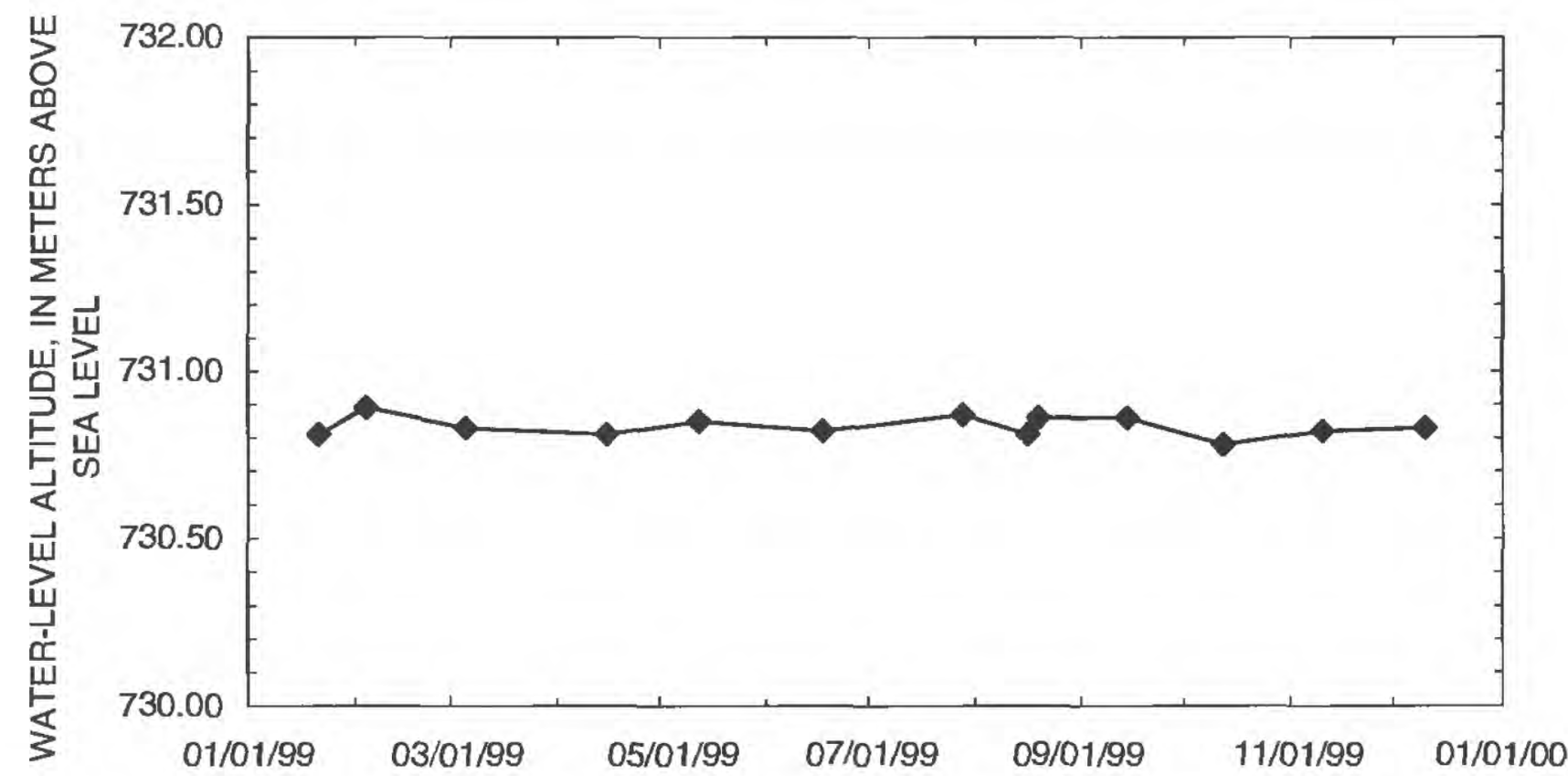

Figure 13. Water-level altitudes for borehole UE-25 WT \#4 during 1999.

Table 7. Measured water-level altitudes, 1999, for borehole UE-25 WT \#4

\begin{tabular}{cccc}
\hline Date & Time & $\begin{array}{c}\text { Water-level altitude } \\
\text { (meters above sea } \\
\text { level) }\end{array}$ & $\begin{array}{c}\text { Equipment } \\
\text { used to } \\
\text { measure water } \\
\text { level }\end{array}$ \\
\hline $01 / 21 / 99$ & 1108 & 730.81 & Chain \#3 \\
$02 / 04 / 99$ & 1154 & 730.89 & Chain \#3 \\
$03 / 05 / 99$ & 1350 & 730.83 & Chain \#3 \\
$04 / 15 / 99$ & 1426 & 730.81 & Chain \#3 \\
$05 / 12 / 99$ & 1111 & 730.85 & Chain \#3 \\
$06 / 17 / 99$ & 1329 & 730.82 & Chain \#3 \\
$07 / 28 / 99$ & 1145 & 730.87 & Chain \#3 \\
$08 / 16 / 99$ & 1456 & 730.81 & Chain \#3 \\
$08 / 19 / 99$ & 921 & 730.86 & Chain \#3 \\
$09 / 14 / 99$ & 1120 & 730.86 & Chain \#3 \\
$10 / 12 / 99$ & 1041 & 730.78 & Chain \#3 \\
$11 / 10 / 99$ & 1026 & 730.82 & Chain \#3 \\
$12 / 10 / 99$ & 1013 & 730.83 & Chain \#3 \\
\hline
\end{tabular}




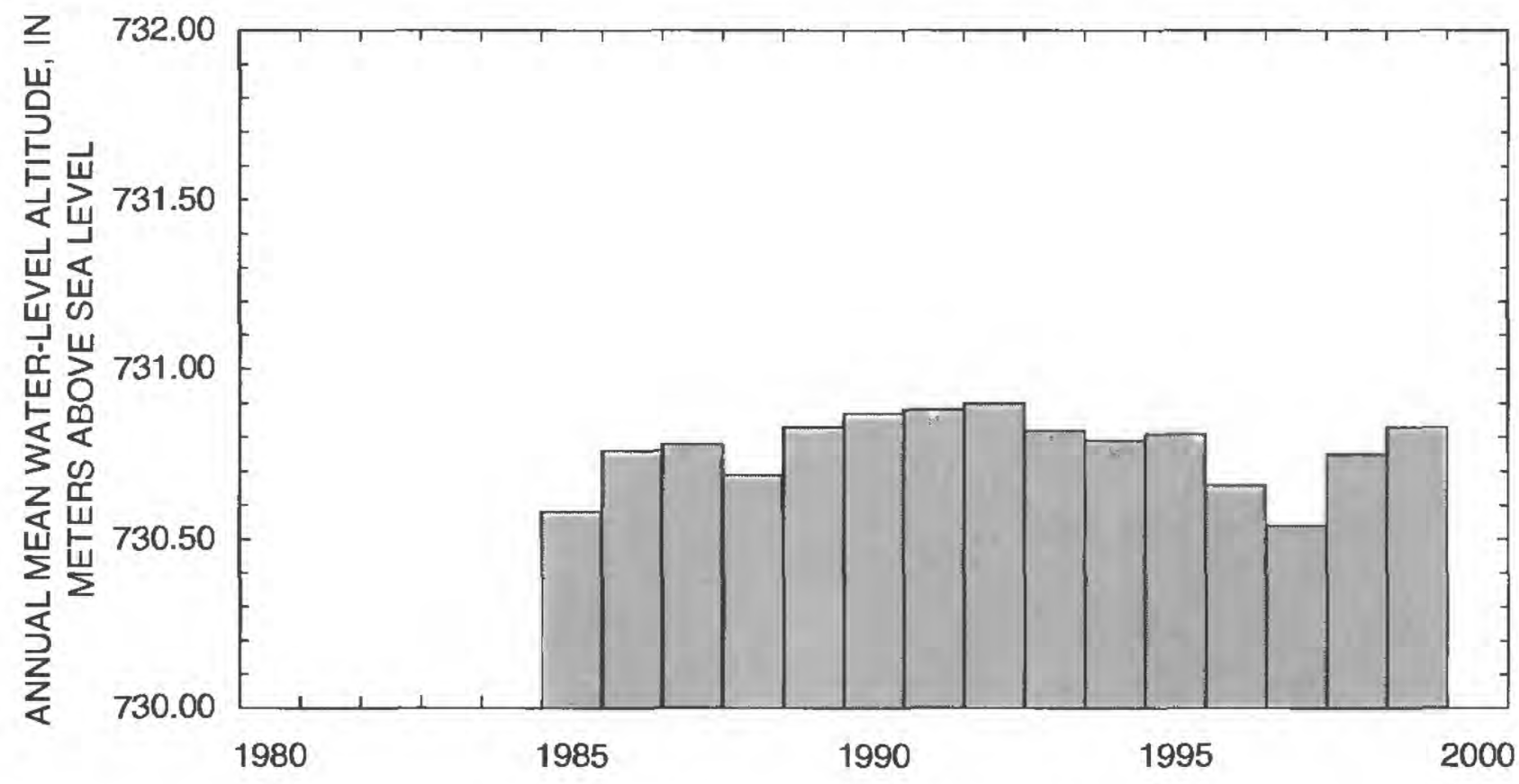

Figure 14. Annual mean water-level altitudes for borehole UE-25 WT \#4.

\section{Borehole UE-25 WT\#6}

\section{Borehole specifications}

1. Location and identification:

Nevada State Plane North American Datum of 1927 Central Zone Coordinates (meters): N 237,920; E 172,067 (U.S. Department of Energy, written commun., 1999, MO9907YMP99025.001)

Latitude and longitude: $36^{\circ} 53^{\prime} 40^{\prime \prime} \mathrm{N}$.; $116^{\circ} 26^{\prime} 46^{\prime \prime} \mathrm{W}$. (Converted from Nevada State Plane North American Datum of 1927 Central Zone Coordinates)

U.S. Geological Survey Site ID: 365340116264601 .

2. Drilling and casing information:

Borehole started: June 20, 1983 (Fenix \& Scisson, Inc., 1986a, p. 21).

Borehole completed: June 29, 1983 (Fenix \& Scisson, Inc., 1986a, p. 21).

Drilling method: Rotary, using rock bits and airfoam circulating medium; core obtained from bottom of the borehole (Robison and others, 1988, p. 35).

Bit diameter, below land surface: 0 to $21.03 \mathrm{~m}$, $374.65 \mathrm{~mm} ; 21.03$ to $76.2 \mathrm{~m}, 250.82 \mathrm{~mm} ; 76.2$ to $381 \mathrm{~m}, 171.45 \mathrm{~mm} ; 381$ to $382.98,158.75$ mm (Fenix \& Scisson. Inc., 1986a, p. 21).

Casing, below land surface: Only surface casing in borehole, to a depth of $76.50 \mathrm{~m}$. (Fenix \& Scisson, Inc., 1986a, p. 21)
Total drilled depth: 382.98 m (Fenix \& Scisson, Inc., 1986a, p. 21).

3. Description of access tube and depth interval for measuring water levels:

62-mm-inside-diameter tubing (Robison and others, 1988, p. 35 ) that has a $3.75-\mathrm{m}$-long well screen on bottom, extending from land surface to a depth of $372.16 \mathrm{~m}$ (Fenix \& Scisson, Inc., 1986a, p. 21); saturated interval of the borehole is within the Calico Hills Formation (Robison and others, 1988, p. 35). Stratigraphic nomenclature presented by Robison revised to agree with stratigraphic nomenclature in Sawyer and others (1994, p. 1305).

4. Information for calculating water-level altitude:

Reference point: Top of metal tag on well casing; altitude $1,314.78 \mathrm{~m}$ (surveyed by U.S. Geological Survey in 1984; Merle E. Southern, National Mapping Division, U.S. Geological Survey, written commun., 1985).

Measurement point: Top of access tube, $0.463 \mathrm{~m}$ above reference point.

Depth correction for borehole deviation from vertical: Computed from borehole deviation survey dated July 6, 1983 (U.S. Department of Energy, 1995, written commun., MOL.19950516.0151), $-0.204 \mathrm{~m}$, based on approximate depth to water of $280 \mathrm{~m} \mathrm{(1992}$ data) or interpolated directly from borehole deviation survey for the October through December 1999 measurements. 
Borehole UE-25 WT\#6 was measured periodically during 1999 with Chain \#3. Water levels fluctuated within a $0.48-\mathrm{m}$ range during 1999 (fig. 15) with the lowest water level being $1,034.82 \mathrm{~m}$ above sea level (01-13-99) and the highest water level being 1,035.30 $\mathrm{m}$ above sea level (11-04-99) (table 8). The mean water-level altitude of the 1999 data was $1,034.95 \mathrm{~m}$ above sea level and was within the range of previous annual mean water-level altitudes from 1985 to 1997 (fig. 16). Annual mean water-level altitudes have generally been rising since 1993 .

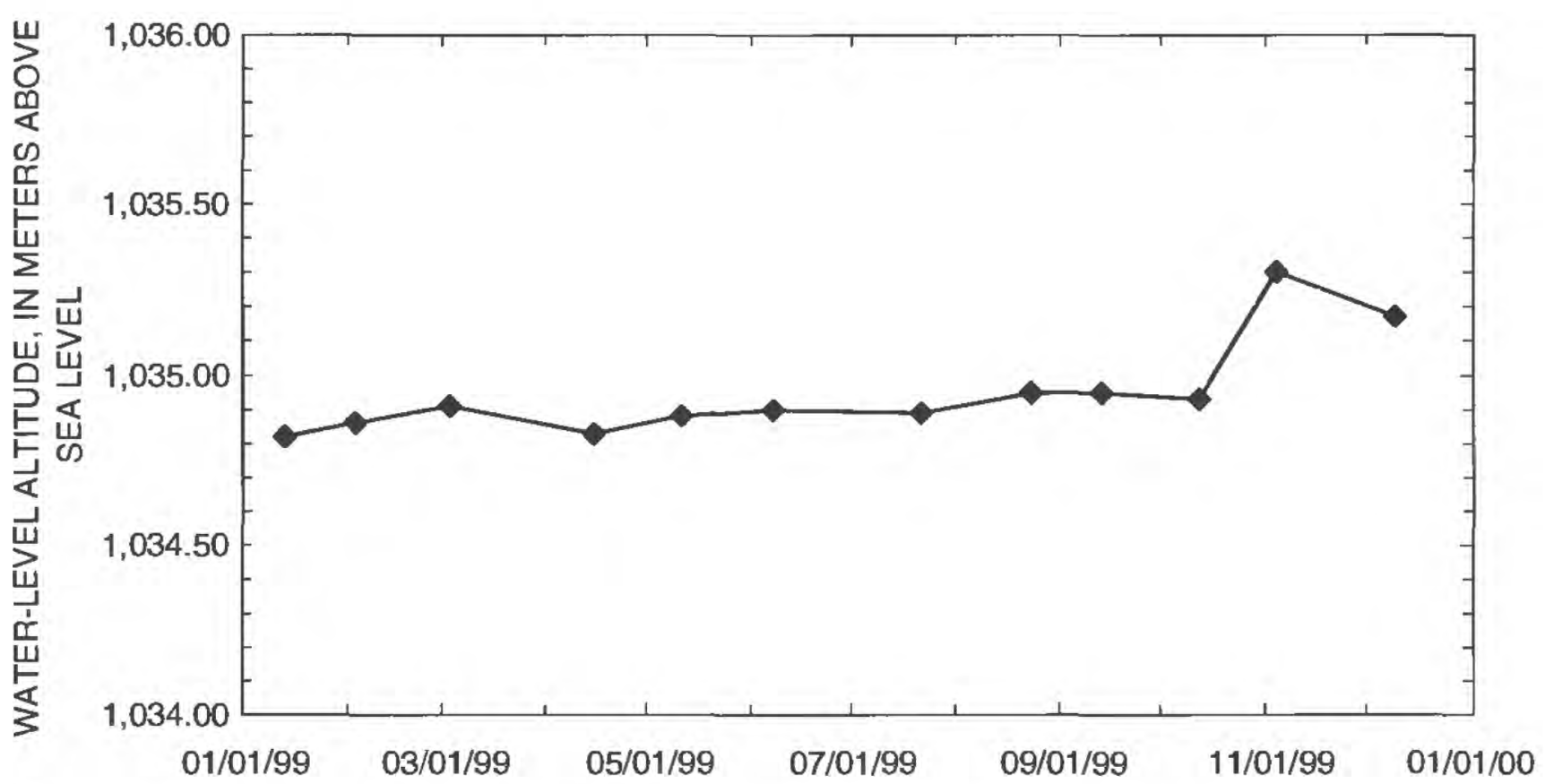

Figure 15. Water-level altitudes for borehole UE-25 WT \#6 during 1999.

Table 8. Measured water-level altitudes, 1999, for borehole UE-25 WT \#6

\begin{tabular}{cccc}
\hline Date & Time & $\begin{array}{c}\text { Water-level altitude } \\
\text { (meters above sea } \\
\text { level) }\end{array}$ & $\begin{array}{c}\text { Equipment } \\
\text { used to } \\
\text { measure water } \\
\text { level }\end{array}$ \\
\hline $01 / 13 / 99$ & 1040 & $1,034.82$ & Chain \#3 \\
$02 / 03 / 99$ & 1117 & $1,034.86$ & Chain \#3 \\
$03 / 03 / 99$ & 1000 & $1,034.91$ & Chain \#3 \\
$04 / 15 / 99$ & 1109 & $1,034.83$ & Chain \#3 \\
$05 / 11 / 99$ & 954 & $1,034.88$ & Chain \#3 \\
$06 / 07 / 99$ & 1012 & $1,034.90$ & Chain \#3 \\
$07 / 21 / 99$ & 1259 & $1,034.89$ & Chain \#3 \\
$08 / 23 / 99$ & 1142 & $1,034.95$ & Chain \#3 \\
$09 / 13 / 99$ & 1306 & $1,034.95$ & Chain \#3 \\
$10 / 12 / 99$ & 1143 & $1,034.93$ & Chain \#3 \\
$11 / 04 / 99$ & 1341 & $1,035.30$ & Chain \#3 \\
$12 / 09 / 99$ & 1415 & $1,035.17$ & Chain \#3 \\
\hline
\end{tabular}




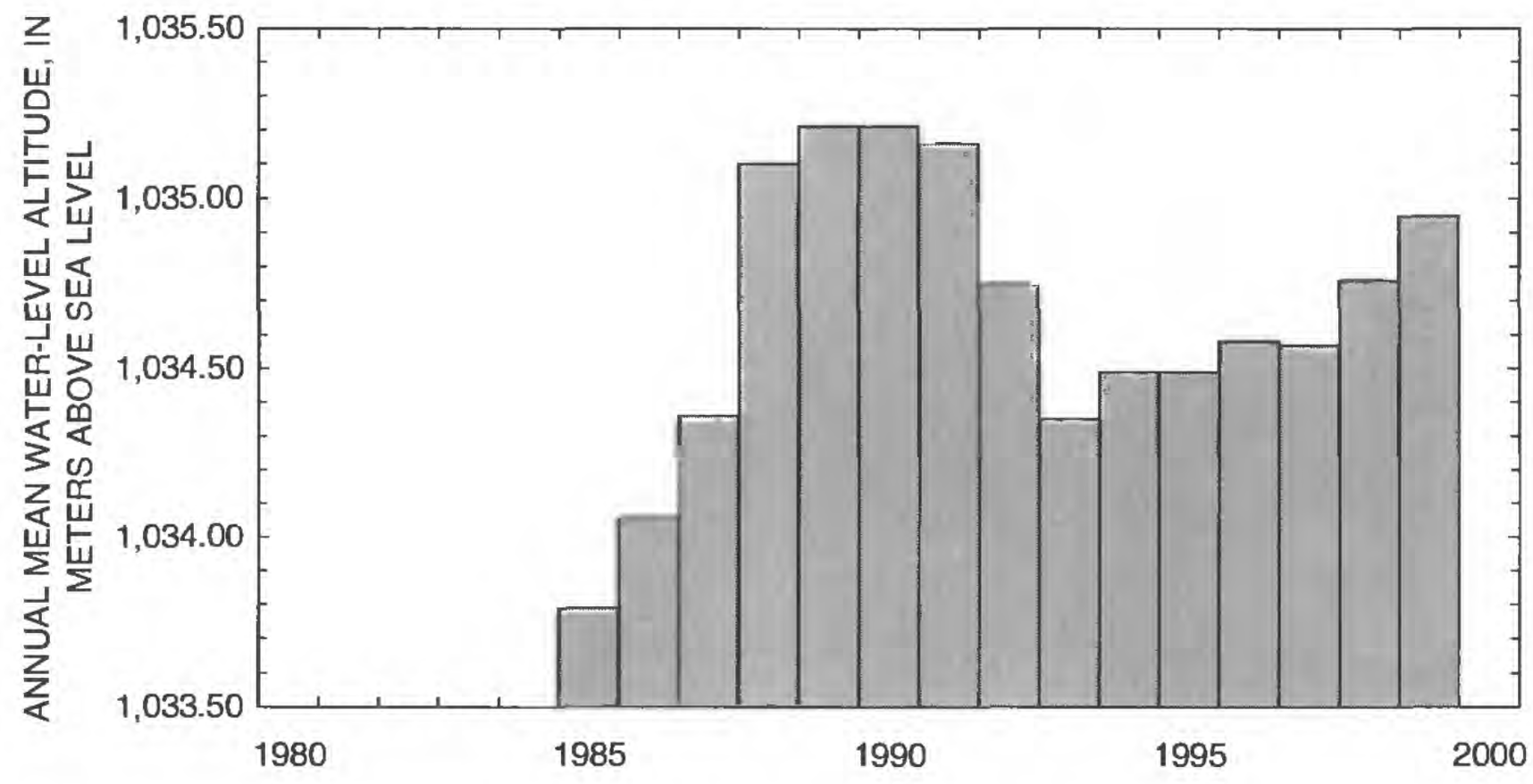

Figure 16. Annual mean water-level altitudes for borehole UE-25 WT \#6.

\section{Borehole USW WT-7}

\section{Borehole specifications}

1. Location and identification:

Nevada State Plane North American Datum of 1927 Central Zone Coordinates (meters): N 230,298; E 168,826 (U.S. Department of Energy, written commun., 1999, MO9907YMP99025.001)

Latitude and longitude: $36^{\circ} 49^{\prime} 33^{\prime \prime} \mathrm{N}$.; $116^{\circ} 28^{\prime} 57^{\prime \prime} W$. (Converted from Nevada State Plane North American Datum of 1927 Central Zone Coordinates)

U.S. Geological Survey Site ID: 364933116285701.

2. Drilling and casing information:

Borehole started: July 19, 1983 (Fenix \& Scisson. Inc., 1986a, p. 81).

Borehole completed: July 26, 1983 (Fenix \& Scisson, Inc., 1986a, p. 81).

Drilling method: Rotary, using rock bits and airfoam circulating medium; core obtained from bottom of the borehole (Robison and others, 1988, p. 38).

Bit diameter, below land surface: $222 \mathrm{~mm}$ (Fenix \& Scisson, Inc., 1986a, p. 81).

Casing, below land surface: Only surface casing in borehole, to a depth of $15.8 \mathrm{~m}$ (Fenix \& Scisson, Inc., 1986a, p. 81).

Total drilled depth: 491 m (Fenix \& Scisson. Inc., 1986a, p. 81).
3. Description of access tube and depth interval for measuring water levels:

62-mm-inside-diameter tubing (Robison and others, 1988 , p. 38) that has a $3.66-\mathrm{m}$-long well screen on the bottom; tubing and attached screen extend from land surface to a depth of 481.28 m (Fenix \& Scisson, Inc., 1986a, p. 81); saturated interval of the borehole is within the Topopah Spring Tuff of the Paintbrush Group and the Prow Pass Tuff of the Crater Flat Group (Robison and others, 1988, p. 38). Stratigraphic nomenclature presented by Robison revised to agree with stratigraphic nomenclature in Sawyer and others (1994, p. 1305).

4. Information for calculating water-level altitude:

Reference point: Top of metal tag on well casing, altitude $1.196 .88 \mathrm{~m}$ (surveyed by U.S. Geological Survey in 1984; Merle E. Southern, National Mapping Division, U.S. Geological Survey, written commun., 1985).

Measurement point: Top of access tube, $0.302 \mathrm{~m}$ above reference point.

Depth correction for borehole deviation from vertical: Computed from borehole deviation survey dated July $23,1983,-0.034 \mathrm{~m}$, based on approximate depth to water of $421 \mathrm{~m}$ (1992 data) or interpolated directly from borehole deviation survey for the October through December 1999 measurements.

Borehole USW WT-7 was measured periodically during 1999 with Chain \#3. Water levels fluctu- 
ated within a $0.10-\mathrm{m}$ range during 1999 (fig. 17) with the lowest water level being $775.92 \mathrm{~m}$ above sea level (08-17-99 and 10-19-99) and the highest water level being $776.02 \mathrm{~m}$ above sea level (11-16-99) (table 9). The mean water-level altitude of the 1999 data was
$775.96 \mathrm{~m}$ above sea level, which equaled the previous maximum annual mean water-level altitude of 1996 for the period 1985 to 1998 (fig. 18). Annual mean water-level altitudes have been rising since 1998 .

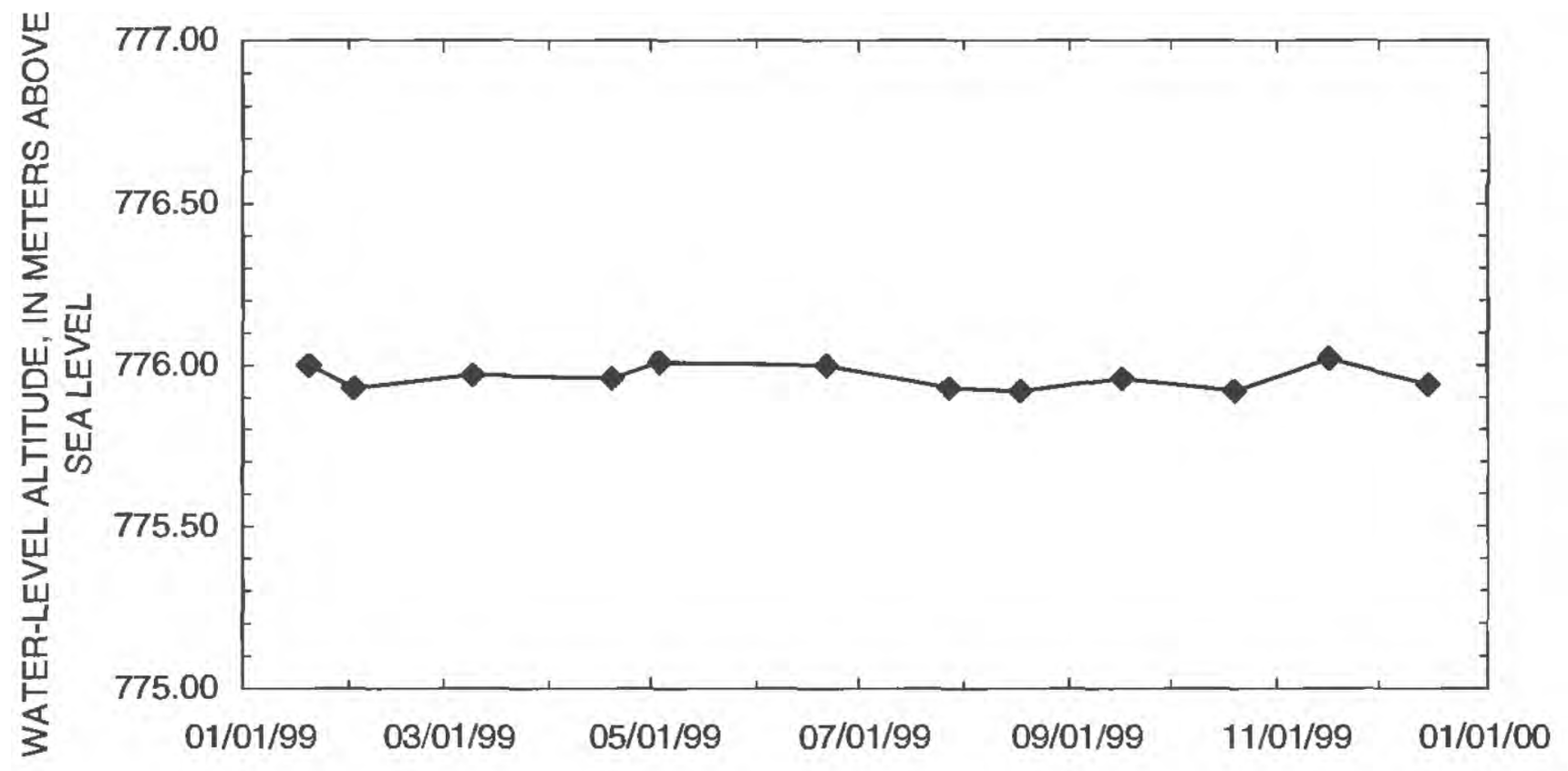

Figure 17. Water-level altitudes for borehole USW WT-7 during 1999.

Table 9. Measured water-level altitudes, 1999, for borehole USW WT-7

\begin{tabular}{cccc}
\hline Date & Time & $\begin{array}{c}\text { Water-level altitude } \\
\text { (meters above sea } \\
\text { level) }\end{array}$ & $\begin{array}{c}\text { Equipment } \\
\text { used to } \\
\text { measure water } \\
\text { level }\end{array}$ \\
\hline $01 / 20 / 99$ & 1235 & 776.00 & Chain \#3 \\
$02 / 02 / 99$ & 1214 & 775.93 & Chain \#3 \\
$03 / 09 / 99$ & 1233 & 775.97 & Chain \#3 \\
$04 / 19 / 99$ & 1148 & 775.96 & Chain \#3 \\
$05 / 03 / 99$ & 1133 & 776.01 & Chain \#3 \\
$06 / 21 / 99$ & 1249 & 776.00 & Chain \#3 \\
$07 / 27 / 99$ & 936 & 775.93 & Chain \#3 \\
$08 / 17 / 99$ & 1140 & 775.92 & Chain \#3 \\
$09 / 16 / 99$ & 1232 & 775.96 & Chain \#3 \\
$10 / 19 / 99$ & 1104 & 775.92 & Chain \#3 \\
$11 / 16 / 99$ & 1209 & 776.02 & Chain \#3 \\
$12 / 15 / 99$ & 1204 & 775.94 & Chain \#3 \\
\hline
\end{tabular}




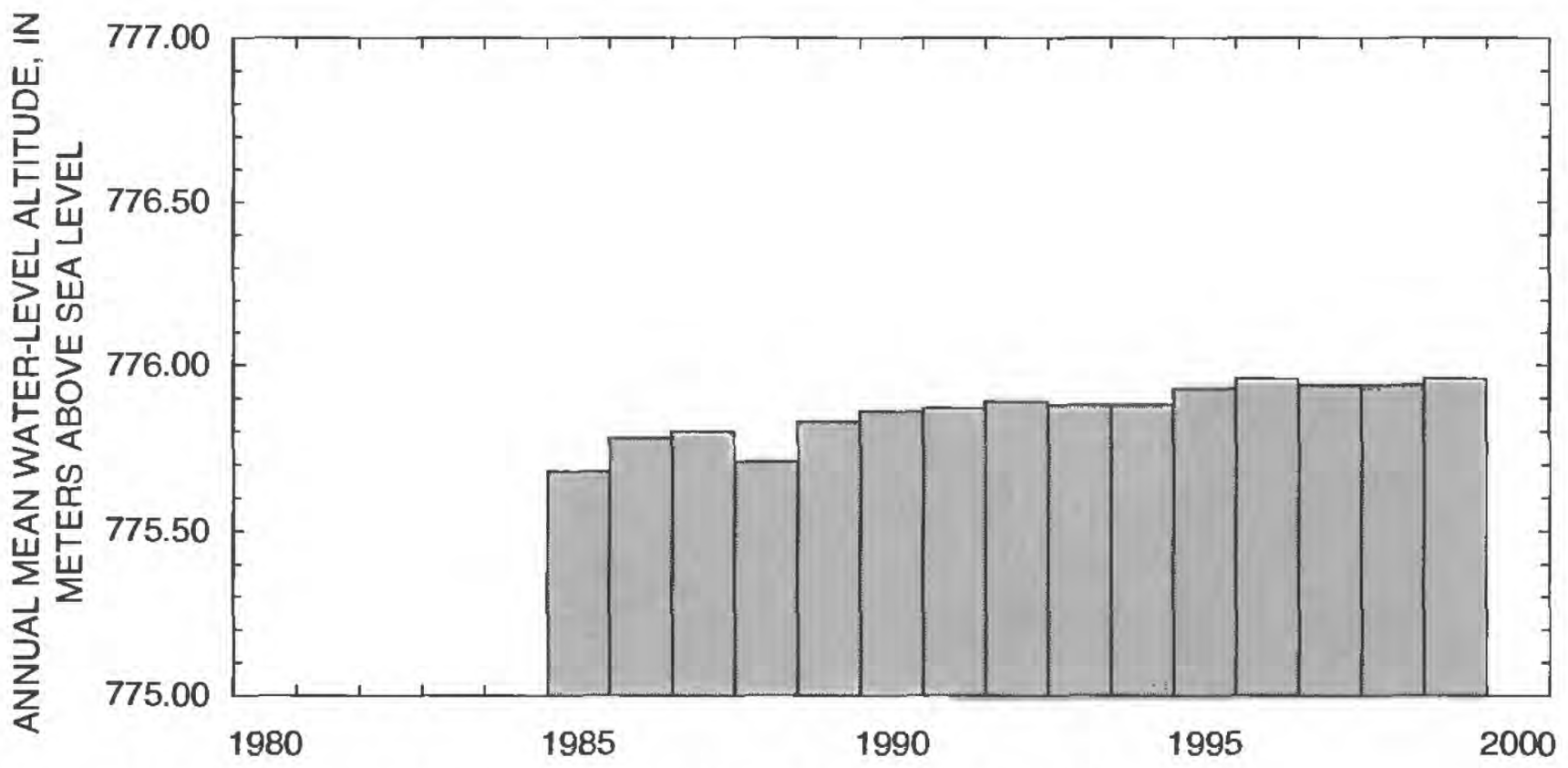

Figure 18. Annual mean water-level altitudes for borehole USW WT-7.

\section{Borehole USW WT-10}

\section{Borehole specifications}

Location and identification:

Nevada State Plane North American Datum of 1927 Central Zone Coordinates (meters): N 228,226; E 168,647 (U.S. Department of Energy, written commun., 1999, MO9907YMP99025.001)

Latitude and longitude: $36^{\circ} 48^{\prime} 25^{\prime \prime} \mathrm{N}$.; $116^{\circ} 29^{\prime} 05^{\prime \prime}$. (Converted from Nevada State Plane North American Datum of 1927 Central Zone Coordinates)

U.S. Geological Survey Site ID: 364825116290501.

5. Drilling and casing information:

Borehole started: July 26, 1983 (Fenix \& Scisson, Inc., 1986a, p. 87).

Borehole completed: August 2, 1983 (Fenix \& Scisson, Inc., 1986a, p. 87).

Drilling method: Rotary, using rock bits and airfoam circulating medium; core obtained from bottom of the borehole (Robison and others, 1988, p. 42).

Bit diameter, below land surface: 0 to $35.36 \mathrm{~m}$, $374.65 \mathrm{~mm} ; 35.36$ to $430.68 \mathrm{~m}, 222.25 \mathrm{~mm}$ (Fenix \& Scisson, Inc., 1986a, p. 87).

Casing, below land surface: Only surface casing in borehole, to a depth of $34.75 \mathrm{~m}$ (Fenix \& Scisson, Inc., 1986a, p. 87).

Total drilled depth: $430.68 \mathrm{~m}$ (Fenix \& Scisson, Inc., 1986a, p. 87).
6. Description of access tube and depth interval for measuring water levels:

62.0-mm-inside-diameter tubing that is capped with a well screen on the bottom. Bottom of tubing is at $426.52 \mathrm{~m}$ below land surface (U.S. Department of Energy, written commun., 1995, DRC.19960905.0053; U.S. Department of Energy, written commun., 1996, DRC.19960905.0054). The screen length is not reported. Two additional tubes are in borehole USW WT-10. The first tube is capped on the bottom with a 2.44 -m-long well screen above the cap. The inside diameter of the tube is not reported. Bottom of tubing is at $424.63 \mathrm{~m}$ below land surface. The second tube is a sealed tube, capped top and bottom and filled with water. The tube is installed in the borehole to allow access for temperature logging. The bottom of the tube is at $427.59 \mathrm{~m}$ below land surface. The inside diameter of the tube is not reported (U.S. Department of Energy, written commun., 1996,

DRC.19960905.0055). Only the tube designated as the access tube placed at $426.52 \mathrm{~m}$ below land surface was used to measure water levels during 1997 and 1998. Saturated interval of the borehole is within the Topopah Spring Tuff of the Paintbrush Group (Robison and others, 1988, p. 42). Stratigraphic nomenclature presented by Robison revised to agree with stratigraphic nomenclature in Sawyer and others (1994, p. 1305). 
7. Information for calculating water-level altitude:

Reference point: Top of metal tag on well casing, altitude $1,123.40 \mathrm{~m}$ (surveyed by U.S. Geological Survey in 1984; Merle E. Southern, National Mapping Division, U.S. Geological Survey, written commun., 1985).

Measurement point: Top of access tube, $0.390 \mathrm{~m}$ above reference point.

Depth correction for borehole deviation from vertical: Computed from borehole deviation survey dated July 30, 1983 (U.S. Department of Energy, 1986. written commun., MOL. 19950516.0153), $-0.030 \mathrm{~m}$, based on approximate depth to water of $347 \mathrm{~m} \mathrm{(1992}$ data) or interpolated directly from borehole deviation survey for the October through December 1999 measurements.

Borehole USW WT-10 was measured periodically during 1999 with Chain \#3. Water levels fluctuated within a $0.11-\mathrm{m}$ range during 1999 (fig. 19) with the lowest water level being $776.06 \mathrm{~m}$ above sea level (02-02-99) and the highest water level being

$776.17 \mathrm{~m}$ above sea level (11-16-99) (table 10). The mean water-level altitude of the 1999 data was $776.11 \mathrm{~m}$ above sea level and was within the range of previous annual mean water-level altitudes from 1985 to 1998 (fig. 20). Annual mean water-level altitudes have been rising since 1997 .

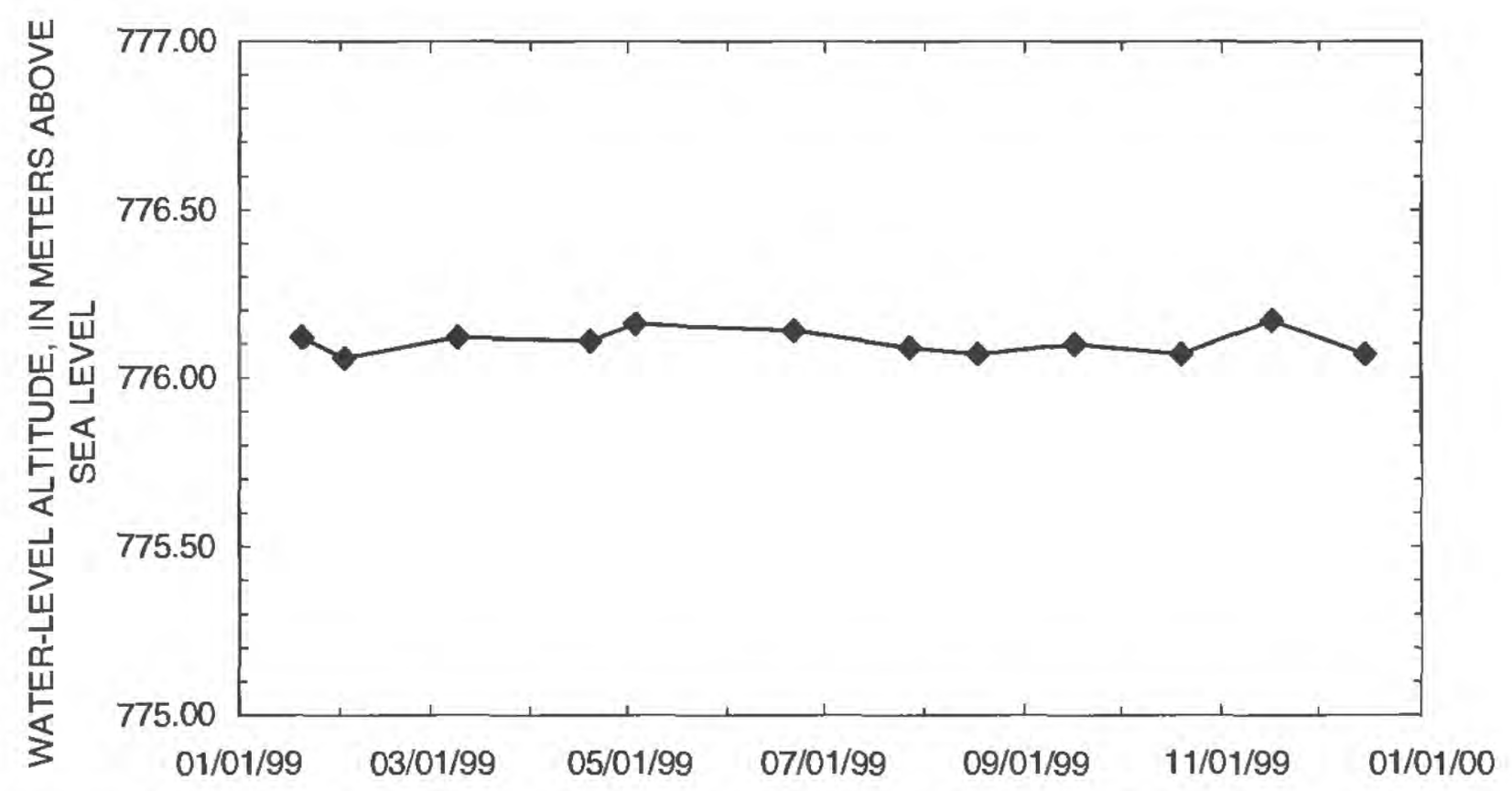

Figure 19. Water-level altitudes for borehole USW WT-10 during 1999.

Table 10. Measured water-level altitudes, 1999, for borehole USW WT-10

\begin{tabular}{cccc}
\hline Date & Time & $\begin{array}{c}\text { Water-level altitude } \\
\text { (meters above sea } \\
\text { level) }\end{array}$ & $\begin{array}{c}\text { Equipment } \\
\text { used to } \\
\text { measure water } \\
\text { level }\end{array}$ \\
\hline $01 / 20 / 99$ & 1003 & 776.12 & Chain \#3 \\
$02 / 02 / 99$ & 1319 & 776.06 & Chain \#3 \\
$03 / 09 / 99$ & 1318 & 776.12 & Chain \#3 \\
$04 / 19 / 99$ & 1248 & 776.11 & Chain \#3 \\
$05 / 03 / 99$ & 1233 & 776.16 & Chain \#3 \\
$06 / 21 / 99$ & 1337 & 776.14 & Chain \#3 \\
$07 / 27 / 99$ & 1045 & 776.09 & Chain \#3 \\
$08 / 17 / 99$ & 1238 & 776.07 & Chain \#3 \\
$09 / 16 / 99$ & 1351 & 776.10 & Chain \#3 \\
$10 / 19 / 99$ & 1144 & 776.07 & Chain \#3 \\
$11 / 16 / 99$ & 1250 & 776.17 & Chain \#3 \\
$12 / 15 / 99$ & 1258 & 776.07 & Chain \#3 \\
\hline
\end{tabular}




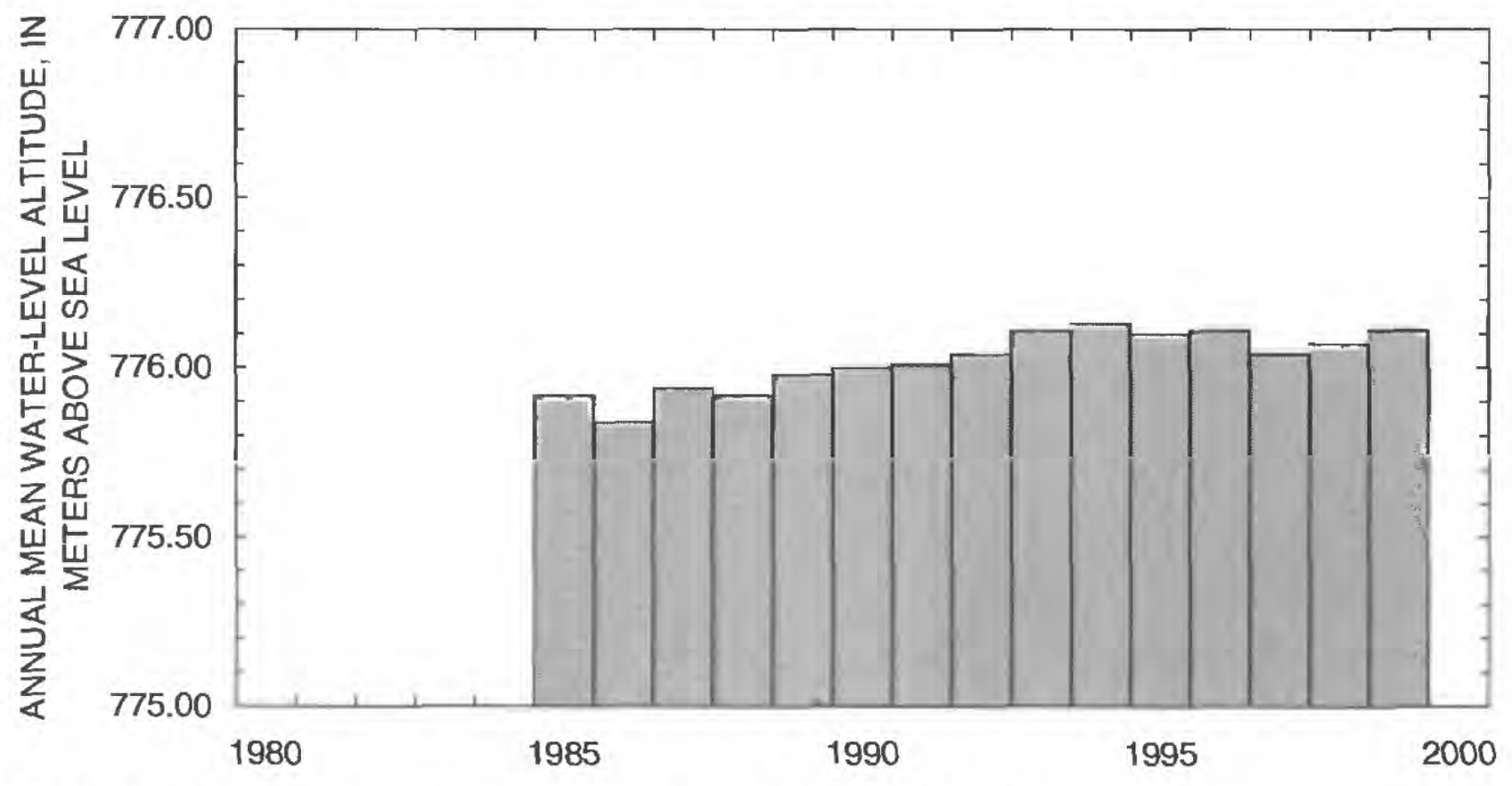

Figure 20. Annual mean water-level altitudes for USW WT-10.

\section{Borehole UE-25 WT\#12}

\section{Borehole specifications}

1. Location and identification:

Nevada State Plane North American Datum of 1927 Central Zone Coordinates (meters): N 225,469; E 172,825 (U.S. Department of Energy, written commun., 1999, MO9907YMP99025.001)

Latitude and longitude: $36^{\circ} 46^{\prime} 56^{\prime \prime} \mathrm{N}$.; $116^{\circ} 26^{\prime} 16^{\prime \prime} \mathrm{W}$. (Converted from Nevada State

Plane North American Datum of 1927 Central Zone Coordinates)

U.S. Geological Survey Site ID: 364656116261601.

2. Drilling and casing information:

Borehole started: August 11, 1983 (Fenix \& Scisson, Inc., 1986a, p. 27).

Borehole completed: August 16, 1983 (Fenix \& Scisson, Inc., 1986a, p. 27).

Drilling method: Rotary, using rock bits and airfoam circulating medium; core obtained from bottom of the borehole (Robison and others, 1988, p. 49).

Bit diameter, below land surface: 0 to $22.86 \mathrm{~m}$, $381 \mathrm{~mm} ; 22.86 \mathrm{~m}$ to $398.68 \mathrm{~m}, 222.25 \mathrm{~mm}$ (Fenix \& Scisson, Inc., 1986a, p. 27).

Casing, below land surface: Only surface casing in borehole, to a depth of $21.34 \mathrm{~m}$ (Fenix \& Scisson, Inc., 1986a, p. 27).

Total drilled depth: 398.68 m (Fenix \& Scisson, Inc., 1986a, p. 27).
3. Description of access tube and depth interval for measuring water levels:

Access tube is capped on the bottom with a well screen above the cap. The bottom of the tube is at $389.26 \mathrm{~m}$ below land surface. The length of screen and inside diameter of the tubing are not reported (U.S. Department of Energy, written commun., 1995, DRC.19960905.0024). Two additional tubes are in borehole UE-25 WT\#12. One is a 60.3 -mm-inside-diameter tubing that is capped on the bottom with a screen above the cap (U.S. Department of Energy, written commun., 1995, DRC.19960905.0027). Accurate information on screen length and depth of tube is not available. The second tube is a 48.42-mm-inside-diameter sealed tube, capped top and bottom and filled with water. The tube is installed in the borehole to allow access for temperature logging (U.S. Department of Energy, written commun., 1995, DRC.19960905.0027). Accurate information on length of tube below land surface is not available. Only the tube designated as the access tube placed at $389.26 \mathrm{~m}$ below land surface was used to measure water levels during 1999. The saturated interval of the borehole is within the Topopah Spring Tuff of the Paintbrush Group and the Calico Hills Formation (Robison and others, 1988, p. 49). Stratigraphic nomenclature presented by Robison revised to agree with stratigraphic nomenclature in Sawyer and others (1994, p. 1305). 
4. Information for calculating water-level altitude:

Reference point: Top of metal tag on well casing, altitude $1,074.74 \mathrm{~m}$ (surveyed by

U.S. Geological Survey in 1984; Merle E. Southern, National Mapping Division, U.S. Geological Survey, written commun., 1985).

Measurement point: Top of access tube, $0.171 \mathrm{~m}$ above reference point.

Depth correction for borehole deviation from vertical: Computed from borehole deviation survey dated August 15, 1983 (U.S. Department of Energy, 1994, written commun., MOL.19950516.0155), $-0.183 \mathrm{~m}$, based on approximate depth to water of $346 \mathrm{~m}$ (1992 data) or interpolated directly from borehole deviation survey for the October through December 1999 measurements.

Borehole UE-25 WT \#12 was measured periodically during 1999 with Chain \#3. Water levels fluctuated within a 0.11-m range during 1999 (fig. 21) with the lowest water level being $729.38 \mathrm{~m}$ above sea level (03-05-99) and the highest water level being $729.49 \mathrm{~m}$ above sea level (12-13-99) (table 11). The mean water-level altitude of the 1999 data was $729.44 \mathrm{~m}$ above sea level and was within the range of previous annual mean water-level altitudes from 1985 to 1998 (fig. 22). Annual mean water-level altitudes have been rising since 1998 .

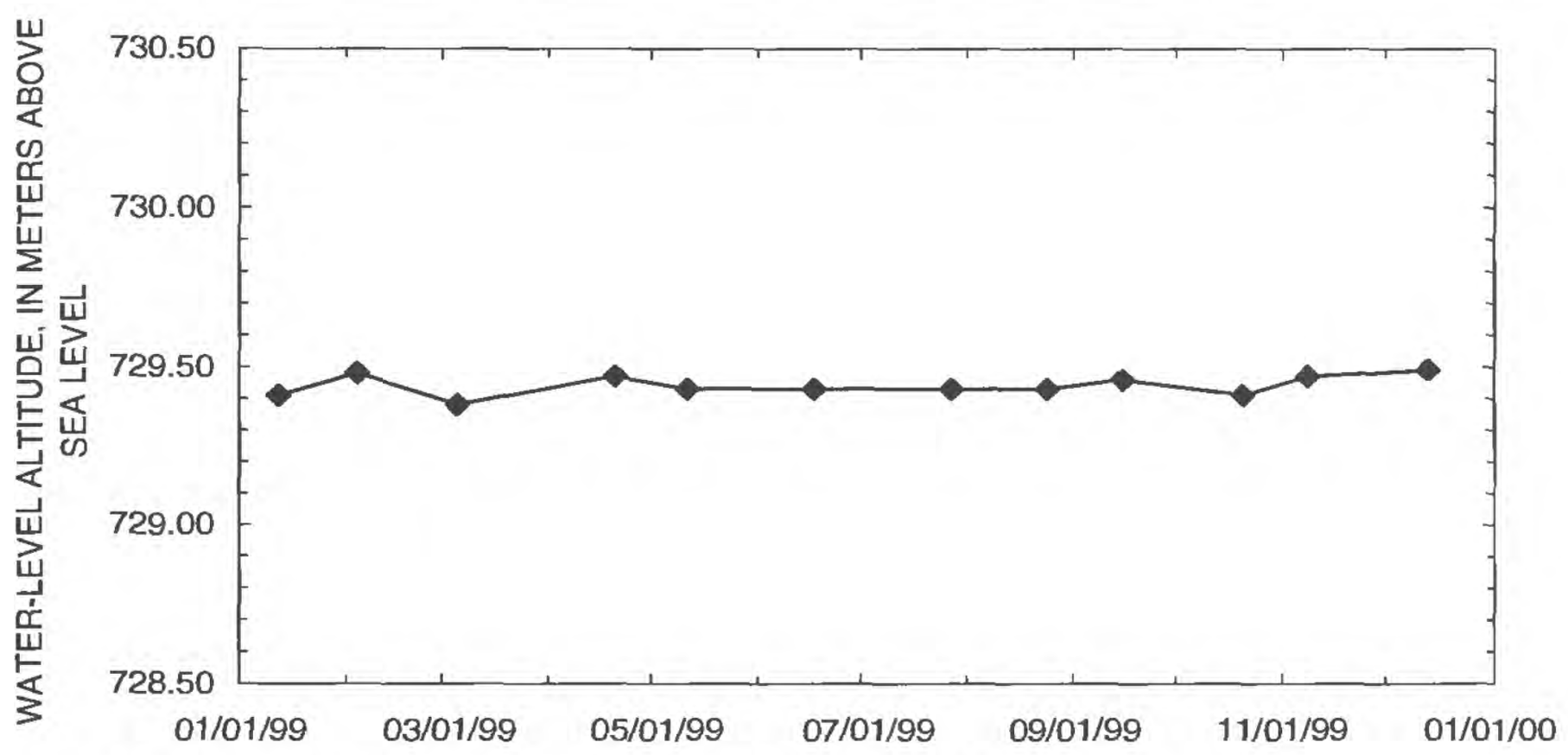

Figure 21. Water-level altitudes for borehole UE-25 WT \#12 during 1999.

Table 11. Measured water-level altitudes, 1999, for borehole UE-25 WT \#12

\begin{tabular}{lccc}
\hline Date & Time & $\begin{array}{c}\text { Water-level altitude } \\
\text { (meters above sea } \\
\text { level) }\end{array}$ & $\begin{array}{c}\text { Equipment } \\
\text { used to } \\
\text { measure water } \\
\text { level }\end{array}$ \\
\hline $01 / 12 / 99$ & 1459 & 729.41 & Chain \#3 \\
$02 / 04 / 99$ & 1417 & 729.48 & Chain \#3 \\
$03 / 05 / 99$ & 1212 & 729.38 & Chain \#3 \\
$04 / 20 / 99$ & 1054 & 729.47 & Chain \#3 \\
$05 / 11 / 99$ & 1601 & 729.43 & Chain \#3 \\
$06 / 17 / 99$ & 1505 & 729.43 & Chain \#3 \\
$07 / 27 / 99$ & 1404 & 729.43 & Chain \#3 \\
$08 / 24 / 99$ & 1048 & 729.43 & Chain \#3 \\
$09 / 15 / 99$ & 1121 & 729.46 & Chain \#3 \\
$10 / 20 / 99$ & 1211 & 729.41 & Chain \#3 \\
$11 / 08 / 99$ & 1427 & 729.47 & Chain \#3 \\
$12 / 13 / 99$ & 1006 & 729.49 & Chain \#3 \\
\hline
\end{tabular}




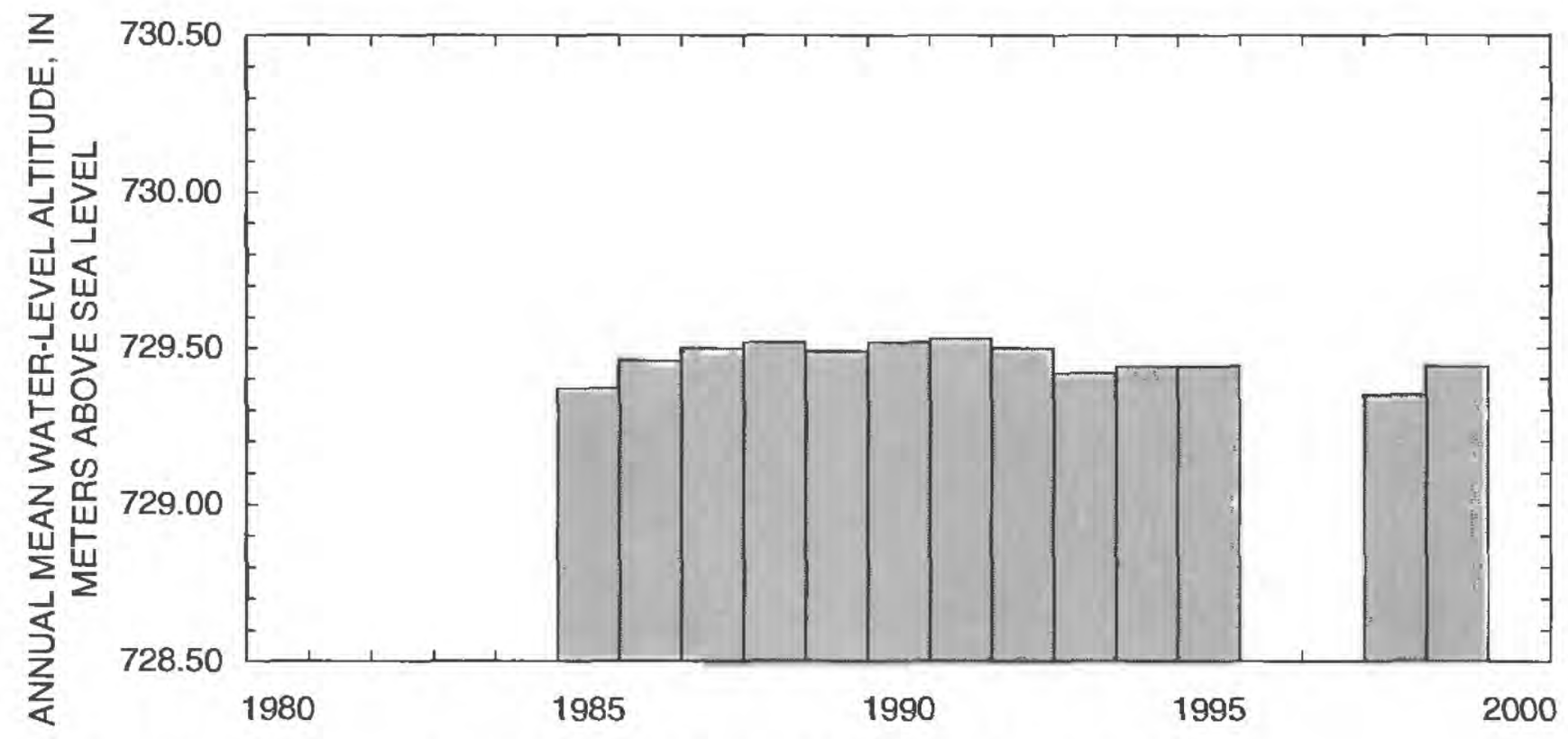

Figure 22. Annual mean water-level altitudes for borehole UE-25 WT \#12.

\section{Borehole UE-25 WT\#13}

\section{Borehole specifications}

1. Location and identification:

Nevada State Plane North American Datum of 1927 Central Zone Coordinates (meters): N 230,699; E 176,431 (U.S. Department of Energy, written commun., 1999. MO9907YMP99025.001)

Latitude and longitude: $36^{\circ} 49^{\prime} 45^{\prime \prime} \mathrm{N}$.; $116^{\circ} 23^{\prime} 50^{\prime \prime}$ W. (Converted from Nevada State Plane North American Datum of 1927 Central Zone Coordinates)

U.S. Geological Survey Site ID: 364945116235001 .

2. Drilling and casing information:

Borehole completed: July 7, 1983 (Fenix \& Scisson. Inc., 1986a, p. 33).

Drilling method: Rotary, using rock bits and airfoam circulating medium; core obtained from bottom of the borehole (Robison and others, 1988, p. 53).

Bit diameter, below land surface: 0 to $14.78 \mathrm{~m}$, $381 \mathrm{~mm} ; 14.78$ to $68.28 \mathrm{~m}, 374.65 \mathrm{~mm} ; 68.28$ to $350.52 \mathrm{~m}, 222.25 \mathrm{~mm} ; 350.52$ to $353.57 \mathrm{~m}$, 204.79 mm (Fenix \& Scisson, Inc., 1986a, p. 33).

Casing, below land surface: Only surface casing in borehole, to a depth of $67.67 \mathrm{~m}$ (Fenix \& Scisson, Inc., 1986a, p. 33).

Total drilled depth: 353.57 m (Fenix \& Scisson, Inc., 1986a, p. 33).
3. Description of access tube and depth interval for measuring water levels:

62-mm-inside-diameter tubing (Robison and others, 1988 , p. 53) that has a $3.66-\mathrm{m}$-long well screen on bottom, extending from land surface to a depth of $346.25 \mathrm{~m}$ (Fenix \& Scisson, Inc., 1986a, p. 33); saturated interval of the borehole is within the Topopah Spring Tuff of the Paintbrush Group (Robison and others, 1988, p. 53). Stratigraphic nomenclature presented by Robison revised to agree with stratigraphic nomenclature in Sawyer and others (1994, p. 1305).

4. Information for calculating water-level altitude:

Reference point: Top of metal tag on well casing; altitude $1,032.51 \mathrm{~m}$ (surveyed by U.S. Geological Survey in 1984; Merle E. Southern, National Mapping Division, U.S. Geological Survey, written commun., 1985).

Measurement point: Top of access tube, $0.305 \mathrm{~m}$ above reference point.

Depth correction for borehole deviation from vertical: Computed from borehole deviation survey dated July 5, 1983 (U.S. Department of Energy, 1986, written commun., MOL.19950516.0156), $-0.012 \mathrm{~m}$, based on approximate depth to water of $303 \mathrm{~m}$ (1992 data) or interpolated directly from borehole deviation survey for the October through December 1999 measurements.

Borehole UE-25 WT \#13 was measured periodically during 1999 with Chain \#3. Water levels flucu- 
ated within a 0.22-m range during 1999 (fig. 23) with the lowest water level being $729.09 \mathrm{~m}$ above sea level (04-16-99) and the highest water level being $729.31 \mathrm{~m}$ above sea level (12-13-99) (table 12). The mean water-level altitude of the 1999 data was
$729.22 \mathrm{~m}$ above sea level and was greater than previous annual mean water-level altitudes from 1985 to 1998 (fig. 24). Annual mean water-level altitudes have been rising since 1997 .

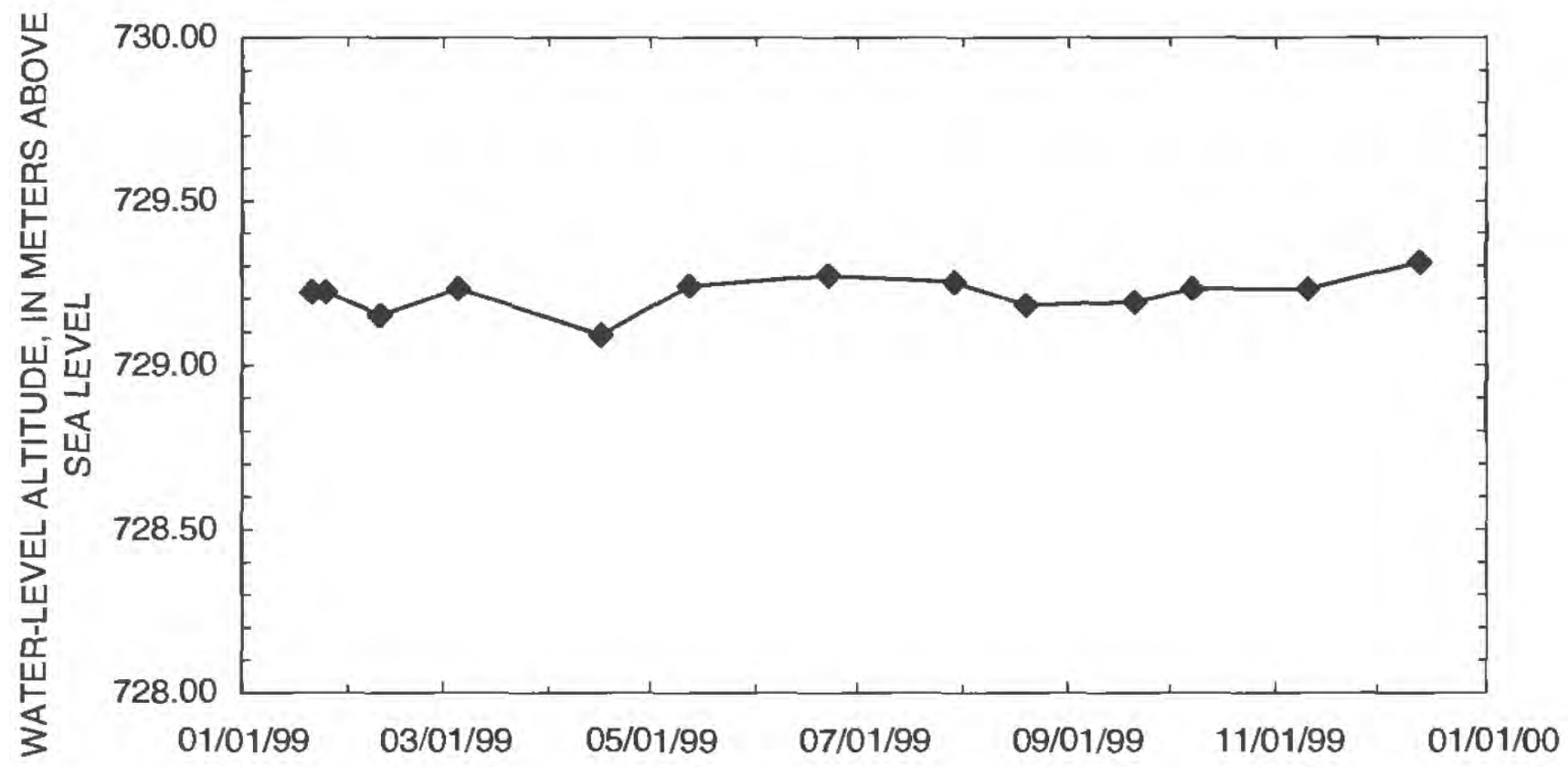

Figure 23. Water-level altitudes for borehole UE-25 WT \#13 during 1999.

Table 12. Measured water-level altitudes, 1999, for borehole UE-25 WT \#13

\begin{tabular}{crcc}
\hline Date & Time & $\begin{array}{c}\text { Water-level altitude } \\
\text { (meters above sea } \\
\text { level) }\end{array}$ & $\begin{array}{c}\text { Equipment } \\
\text { used to } \\
\text { measure water } \\
\text { level }\end{array}$ \\
\hline $01 / 21 / 99$ & 1309 & 729.22 & Chain \#3 \\
$01 / 25 / 99$ & 810 & 729.22 & Chain \#3 \\
$02 / 10 / 99$ & 1502 & 729.15 & Chain \#3 \\
$03 / 05 / 99$ & 1532 & 729.23 & Chain \#3 \\
$04 / 16 / 99$ & 1511 & 729.09 & Chain \#3 \\
$05 / 12 / 99$ & 1403 & 729.24 & Chain \#3 \\
$06 / 22 / 99$ & 1225 & 729.27 & Chain \#3 \\
$07 / 29 / 99$ & 1037 & 729.25 & Chain \#3 \\
$08 / 19 / 99$ & 1133 & 729.18 & Chain \#3 \\
$09 / 20 / 99$ & 1140 & 729.19 & Chain \#3 \\
$10 / 07 / 99$ & 1208 & 729.23 & Chain \#3 \\
$11 / 10 / 99$ & 1104 & 729.23 & Chain \#3 \\
$12 / 13 / 99$ & 1422 & 729.31 & Chain \#3 \\
\hline
\end{tabular}




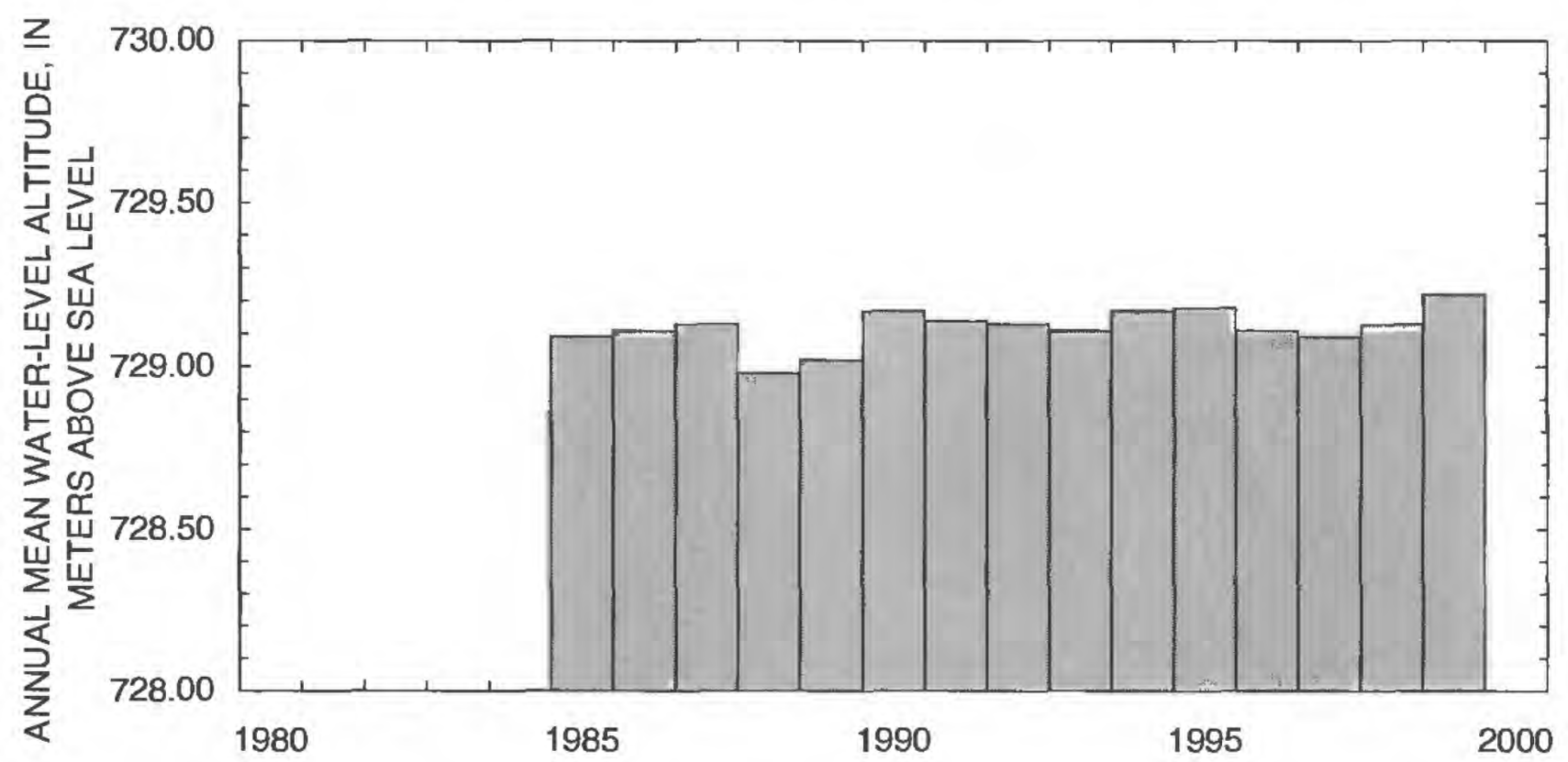

Figure 24. Annual mean water-level altitudes for borehole UE-25 WT \#13.

\section{Borehole UE-25 WT\#14}

\section{Borehole specifications}

Location and identification:

Nevada State Plane North American Datum of 1927 Central Zone Coordinates (meters): N 232,151; E 175,324 (U.S. Department of Energy, written commun., 1999, MO9907YMP99025.001)

Latitude and longitude: $36^{\circ} 50^{\prime} 32^{\prime \prime} \mathrm{N}$.; $116^{\circ} 24^{\prime} 35^{\prime \prime}$ W. (Converted from Nevada State Plane North American Datum of 1927 Central Zone Coordinates)

U.S. Geological Survey Site ID: 3650321 l 6243501 .

5. Drilling and casing information:

Borehole started: August 17, 1983 (Fenix \& Scisson, Inc., 1986a, p. 39).

Borehole completed: September 30, 1983 (Fenix \& Scisson, Inc., 1986a, p. 39).

Drilling method: Rotary, using rock bits and airfoam circulating medium; core obtained from bottom of the borehole (Robison and others. 1988, p. 56).

Bit diameter, below land surface: 0 to $38.25 \mathrm{~m}$. $381 \mathrm{~mm} ; 38.25$ to $399.29 \mathrm{~m}, 222.25 \mathrm{~mm}$ (Fenix \& Scisson, Inc., 1986a, p. 39).

Casing, below land surface: Surface casing only, to a depth of $36.58 \mathrm{~m}$ (Fenix \& Scisson, Inc., 1986a, p. 39).
Total drilled depth: 399.29 m (Fenix \& Scisson, Inc., 1986a, p. 39).

6. Description of access tube and depth interval for measuring water levels:

62-mm-inside-diameter tubing (Robison and others, 1988, p. 56) that has a 3.66-m-long well screen on the bottom; tubing and attached screen extend from land surface to a depth of 397.15 m (Fenix \& Scisson, Inc., 1986a, p. 39); saturated interval of the borehole is within the Topopah Spring Tuff of the Paintbrush Group and the Calico Hills Formation (Robison and others, 1988, p. 56). Stratigraphic nomenclature presented by Robison revised to agree with stratigraphic nomenclature in Sawyer and others (1994, p. 1305).

7. Information for calculating water-level altitude:

Reference point: Top of metal tag on well casing, altitude $1,076.05 \mathrm{~m}$ (surveyed by U.S. Geological Survey in 1984; Merle E. Southern, National Mapping Division, U.S. Geological Survey, written commun., 1985).

Measurement point: Top of access tube, $0.311 \mathrm{~m}$ above reference point.

Depth correction for borehole deviation from vertical: Computed from borehole deviation survey dated September 27, 1983, $-0.085 \mathrm{~m}$, based on approximate depth to water of $346 \mathrm{~m}$ (1992 data) or interpolated directly from borehole deviation survey for the October through December 1999 measurements. 
Borehole UE-25 WT \#14 was measured periodically during 1999 with Chain \#3. Water levels fluctuated within a 0.14-m range during 1999 (fig. 25) with the lowest water level being $729.58 \mathrm{~m}$ above sea level (01-27-99) and the highest water level being $729.72 \mathrm{~m}$ above sea level (10-06-99 and 12-13-99) (table 13). The mean water-level altitude of the 1999 data was $729.67 \mathrm{~m}$ above sea level and was within the range of previous annual mean water-level altitudes from 1985 to 1998 (fig. 26). Annual mean water-level altitudes have been rising since 1997 .

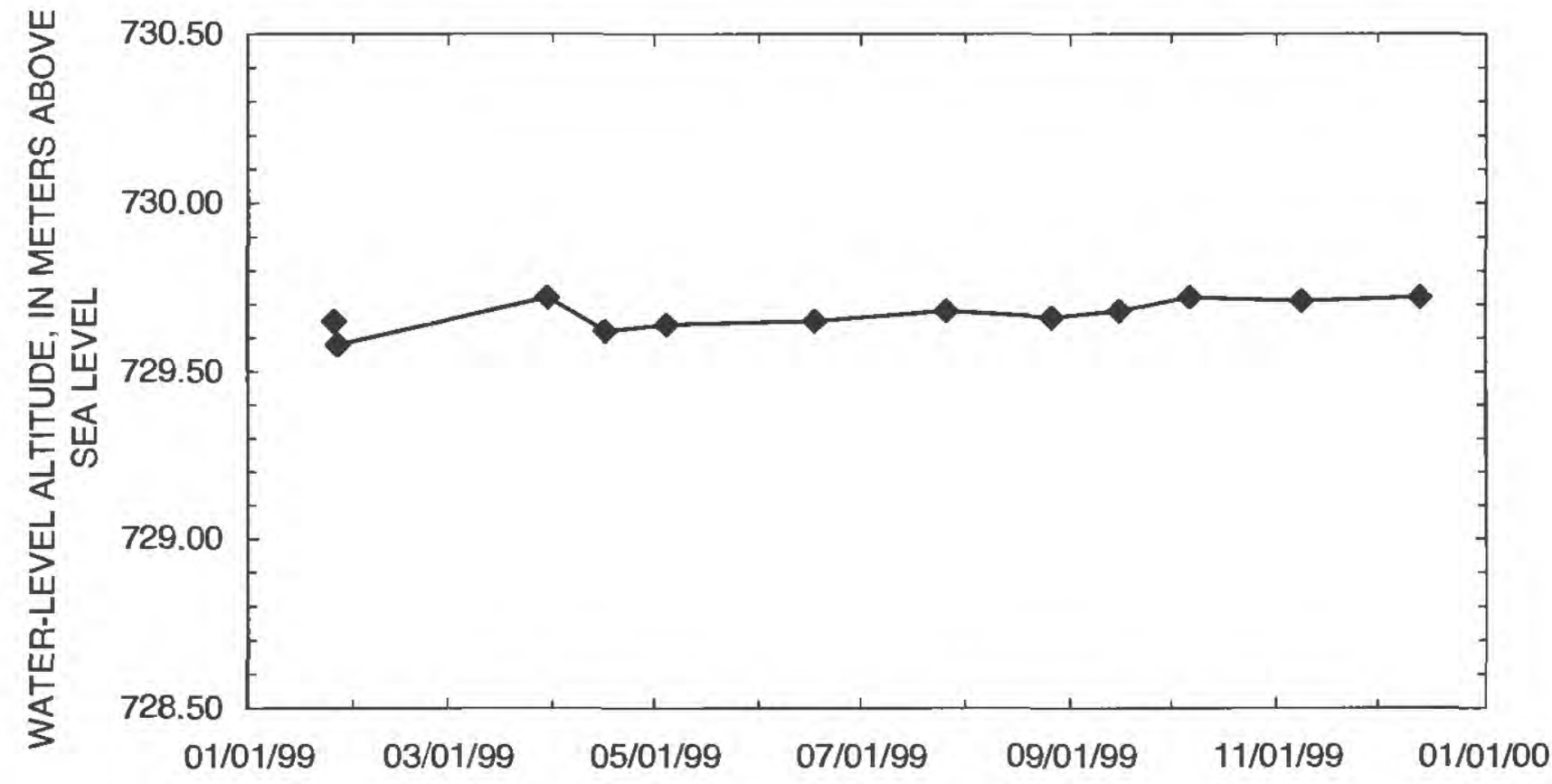

Figure 25. Water-level altitudes for borehole UE-25 WT \#14 during 1999.

Table 13. Measured water-level altitudes, 1999, for borehole UE-25 WT \#14

\begin{tabular}{cccc}
\hline Date & Time & $\begin{array}{c}\text { Water-level altitude } \\
\text { (meters above sea } \\
\text { level) }\end{array}$ & $\begin{array}{c}\text { Equipment } \\
\text { used to } \\
\text { measure water } \\
\text { level }\end{array}$ \\
\hline $01 / 26 / 99$ & 1521 & 729.65 & Chain \#3 \\
$01 / 27 / 99$ & 1216 & 729.58 & Chain \#3 \\
$03 / 30 / 99$ & 1229 & 729.72 & Chain \#3 \\
$04 / 16 / 99$ & 1310 & 729.62 & Chain \#3 \\
$05 / 04 / 99$ & 951 & 729.64 & Chain \#3 \\
$06 / 17 / 99$ & 1234 & 729.65 & Chain \#3 \\
$07 / 26 / 99$ & 1454 & 729.68 & Chain \#3 \\
$08 / 26 / 99$ & 1523 & 729.66 & Chain \#3 \\
$09 / 15 / 99$ & 1017 & 729.68 & Chain \#3 \\
$10 / 06 / 99$ & 1130 & 729.72 & Chain \#3 \\
$11 / 08 / 99$ & 1328 & 729.71 & Chain \#3 \\
$12 / 13 / 99$ & 1317 & 729.72 & Chain \#3 \\
\hline
\end{tabular}




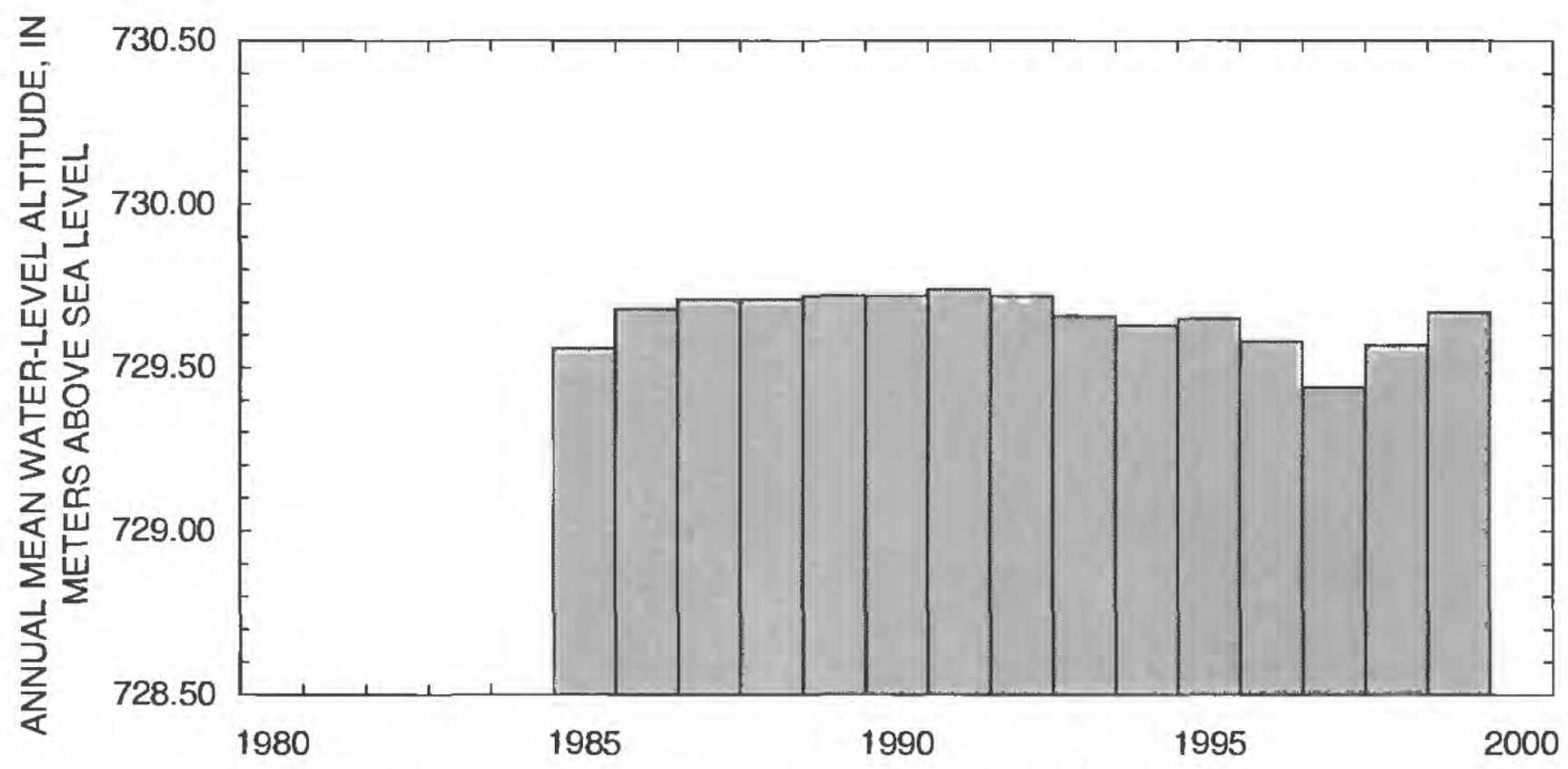

Figure 26. Annual mean water-level altitudes for borehole UE-25 WT \#14.

\section{Borehole UE-25 WT\#15}

\section{Borehole specifications}

\section{Location and identification:}

Nevada State Plane North American Datum of 1927 Central Zone Coordinates (meters): N 233,512; E 176,725 (U.S. Department of Energy, written commun., 1999 , MO9907YMP99025.001)

Latitude and longitude: $36^{\circ} 51^{\prime} 16^{\prime \prime} \mathrm{N}$.; $116^{\circ} 23^{\prime} 38^{\prime \prime}$ W. (Converted from Nevada State Plane North American Datum of 1927 Central Zone Coordinates)

U.S. Geological Survey Site ID: 365116116233801 .

2. Drilling and casing information:

Borehole started: November 12, 1983 (Fenix \& Scisson, Inc., 1986a, p. 45).

Borehole completed: November 22, 1983 (Fenix \& Scisson, Inc., 1986a, p. 45).

Drilling method: Rotary, using rock bits and airfoam circulating medium; core obtained from bottom of the borehole (Robison and others, 1988 , p. 60).

Bit diameter, below land surface: 0 to $39.62 \mathrm{~m}$, $374.65 \mathrm{~mm} ; 39.62$ to $414.53 \mathrm{~m}, 222.25 \mathrm{~mm}$ (Fenix \& Scisson, Inc., 1986a, p. 45).

Casing, below land surface: Surface casing only, to a depth of $38.71 \mathrm{~m}$ (Fenix \& Scisson, Inc., 1986a, p. 45).
Total drilled depth: 414.53 m (Fenix \& Scisson, Inc., 1986a, p. 45).

3. Description of access tube and depth interval for measuring water levels:

62-mm-inside-diameter tubing (Robison and others, 1988, p. 60) that has a $3.66-\mathrm{m}$-long well screen on the bottom; tubing and attached screen extend from land surface to a depth of 406.91 m (Fenix \& Scisson, Inc., 1986a, p. 45); saturated interval of the borehole is within the Topopah Spring Tuff of the Paintbrush Group (Robison and others, 1988, p. 60). Stratigraphic nomenclature presented by Robison revised to agree with stratigraphic nomenclature in Sawyer and others (1994, p. 1305).

4. Information for calculating water-level altitude:

Reference point: Top of metal tag on well casing, altitude $1,082.94 \mathrm{~m}$ (surveyed by U.S. Geological Survey in 1984; Merle E. Southern, National Mapping Division, U.S. Geological Survey, written commun., 1985).

Measurement point: Top of access tube, $0.314 \mathrm{~m}$ above reference point.

Depth correction for borehole deviation from vertical: Computed from borehole deviation survey dated November 19, 1983 (U.S. Department of Energy, 1986, written commun., MOL. 19950516.0158), $-0.189 \mathrm{~m}$, based on approximate depth to water of $354 \mathrm{~m}$ (1992 data) or interpolated directly from borehole 
deviation survey for the October through December 1999 measurements.

Borehole UE-25 WT \#15 was measured periodically during 1999 with Chain \#3. Water levels fluctuated within a 0.19-m range during 1999 (fig. 27) with the lowest water level being $729.19 \mathrm{~m}$ above sea level (04-15-99) and the highest water level being
$729.38 \mathrm{~m}$ above sea level (03-03-99) (table 14). The mean water-level altitude of the 1999 data was $729.30 \mathrm{~m}$ above sea level and was greater than previous annual mean water-level altitudes from 1985 to 1998 (fig. 28). Annual mean water-level altitudes have been rising since 1996 .

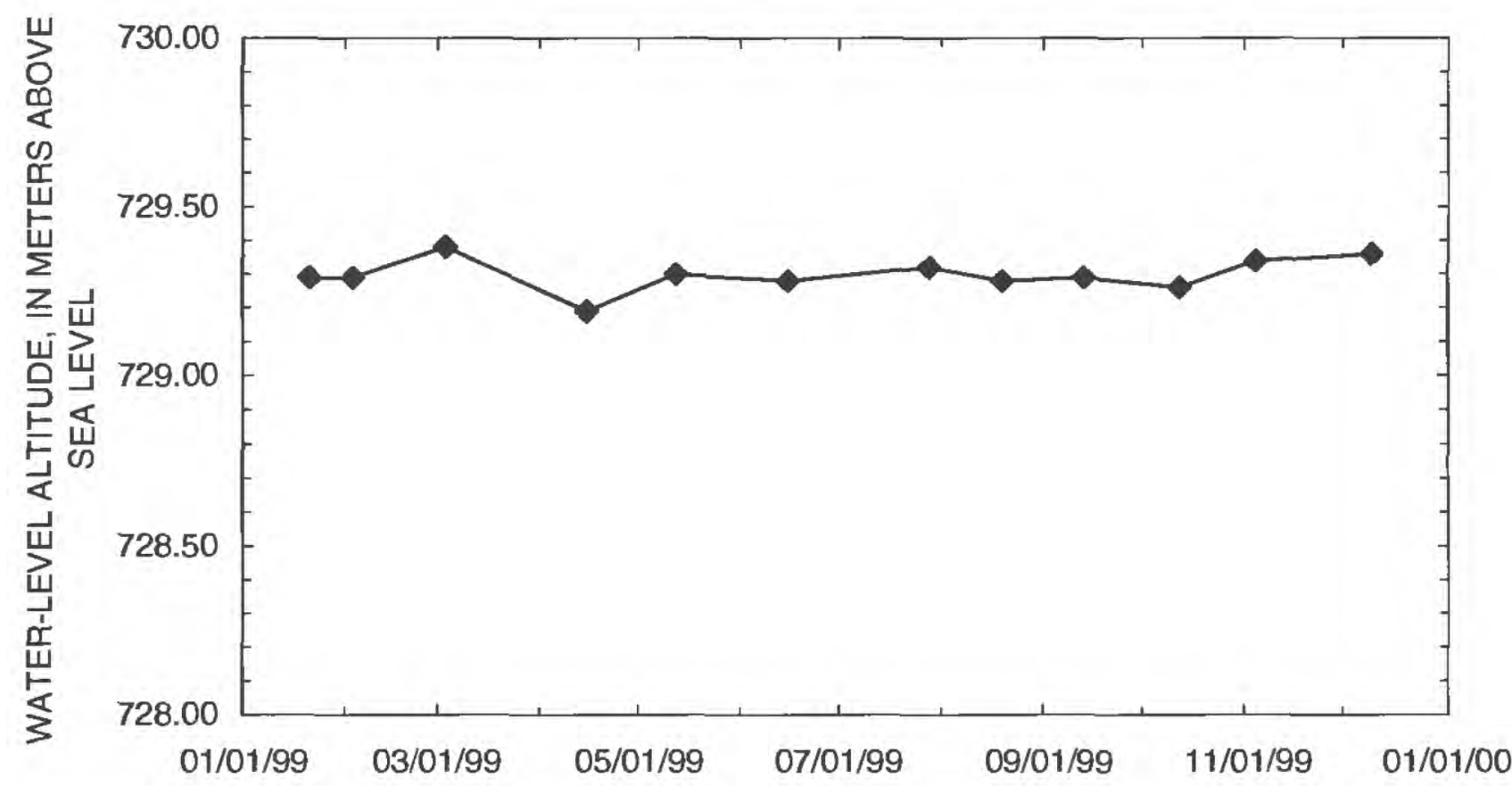

Figure 27. Water-level altitudes for borehole UE-25 WT \#15 during 1999.

Table 14. Measured water-level altitudes, 1999, for borehole UE-25 WT \#15

\begin{tabular}{cccc}
\hline Date & Time & $\begin{array}{c}\text { Water-level altitude } \\
\text { (meters above sea } \\
\text { level) }\end{array}$ & $\begin{array}{c}\text { Equipment } \\
\text { used to } \\
\text { measure water } \\
\text { level }\end{array}$ \\
\hline $01 / 21 / 99$ & 1232 & 729.29 & Chain \#3 \\
$02 / 03 / 99$ & 1406 & 729.29 & Chain \#3 \\
$03 / 03 / 99$ & 1321 & 729.38 & Chain \#3 \\
$04 / 15 / 99$ & 1249 & 729.19 & Chain \#3 \\
$05 / 12 / 99$ & 1254 & 729.30 & Chain \#3 \\
$06 / 15 / 99$ & 816 & 729.28 & Chain \#3 \\
$07 / 28 / 99$ & 1546 & 729.32 & Chain \#3 \\
$08 / 19 / 99$ & 1027 & 729.28 & Chain \#3 \\
$09 / 13 / 99$ & 1437 & 729.29 & Chain \#3 \\
$10 / 12 / 99$ & 1315 & 729.26 & Chain \#3 \\
$11 / 04 / 99$ & 1505 & 729.34 & Chain \#3 \\
$12 / 09 / 99$ & 1530 & 729.36 & Chain \#3 \\
\hline
\end{tabular}




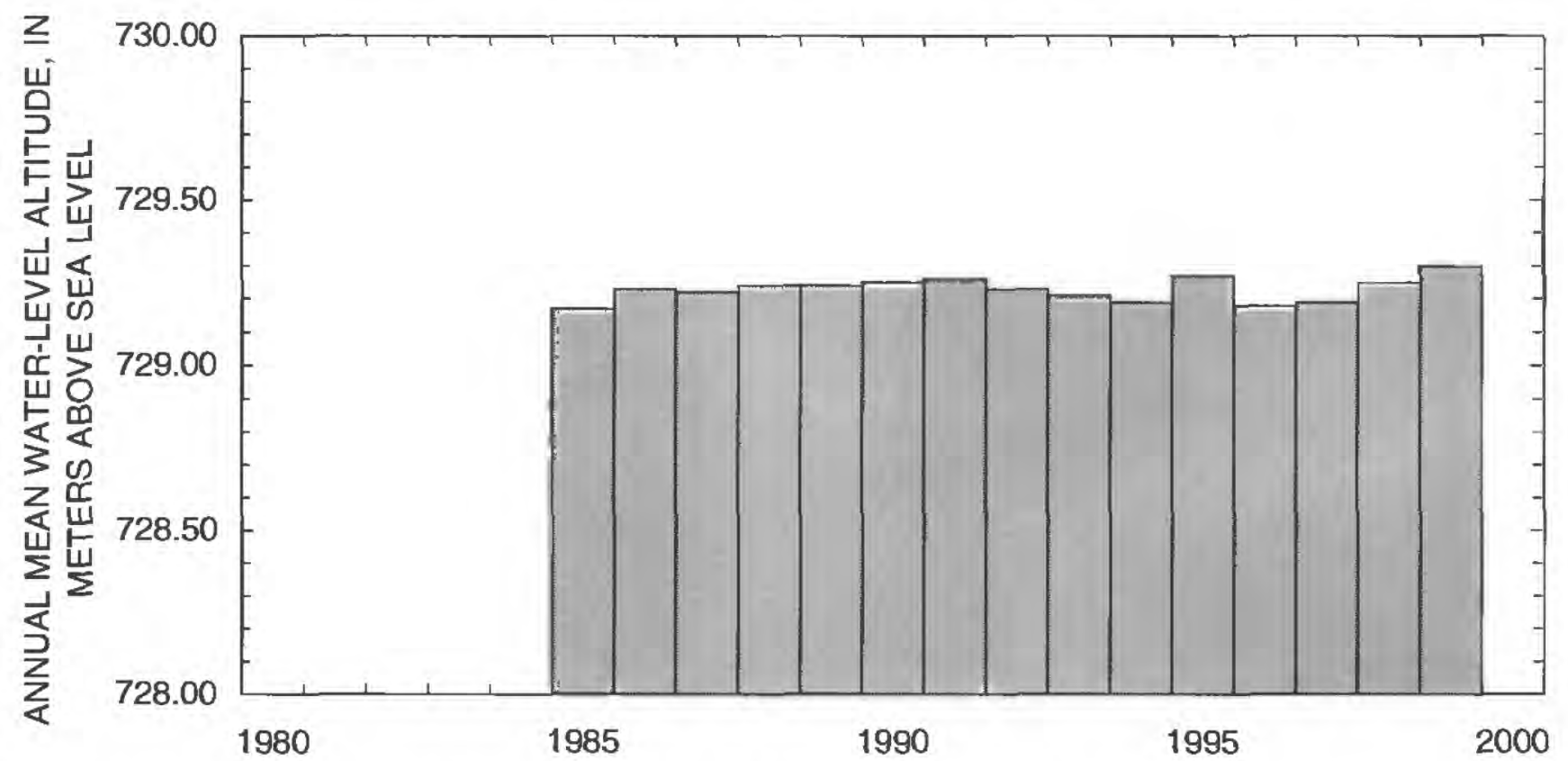

Figure 28. Annual mean water-level altitudes for borehole UE-25 WT \#15.

\section{Borehole UE-25 WT\#16}

\section{Borehole specifications}

1. Location and identification:

Nevada State Plane North American Datum of 1927 Central Zone Coordinates (meters): N 236,043; E 173,856 (U.S. Department of Energy, written commun., 1999, MO9907YMP99025.001)

Latitude and longitude: $36^{\circ} 52^{\prime} 39^{\prime \prime} \mathrm{N}$.; $116^{\circ} 25^{\prime} 34^{\prime \prime} \mathrm{W}$. (Converted from Nevada State Plane North American Datum of 1927 Central Zone Coordinates)

U.S. Geological Survey Site ID: 365239116253401 .

2. Drilling and casing information:

Borehole started: November 2, 1983 (Fenix \& Scisson, Inc., 1986a, p. 51).

Borehole completed: November 10, 1983 (Fenix \& Scisson, Inc., 1986a, p. 51).

Drilling method: Rotary, using rock bits and airfoam circulating medium; core obtained from bottom of the core hole (Robison and others, 1988, p. 64).

Bit diameter, below land surface: 0 to $32.92 \mathrm{~m}$, $374.65 \mathrm{~mm} ; 32.92$ to $521.21 \mathrm{~m}, 222.25 \mathrm{~mm}$ (Fenix \& Scisson, Inc., 1986a, p. 51).

Casing, below land surface: Surface casing only, to a depth of $31.09 \mathrm{~m}$ (Fenix \& Scisson, Inc., 1986a, p. 51).
Total drilled depth: $521.21 \mathrm{~m}$ (Fenix \& Scisson. Inc., 1986a, p. 51).

3. Description of access tube and depth interval for measuring water levels:

62-mm-inside-diameter tubing (Robison and others, 1988, p. 64) that has a $3.66-\mathrm{m}$-long well screen on bottom, extending from land surface to a depth of $513.89 \mathrm{~m}$ (Fenix \& Scisson, Inc., 1986a, p. 51); saturated interval of borehole is within the Calico Hills Formation (Robison and others, 1988, p. 64). Stratigraphic nomenclature presented by Robison revised to agree with stratigraphic nomenclature in Sawyer and others $(1994$, p. 1305).

4. Information for calculating water-level altitude:

Reference point: Top of metal tag on well casing; altitude $1,210.63 \mathrm{~m}$ (surveyed by U.S. Geological Survey in 1984; Merle E. Southern, National Mapping Division, U.S. Geological Survey, written commun., 1985).

Measurement point: Top of access tube, $0.314 \mathrm{~m}$ above reference point.

Depth correction for borehole deviation from vertical: Computed from borehole deviation survey dated November 7, 1983 (U.S.

Department of Energy. 1994, written commun., MOL.19950516.0159), $-0.064 \mathrm{~m}$, based on approximate depth to water of $472 \mathrm{~m}$ (1992 data) or interpolated directly from borehole deviation survey for the October through December 1999 measurements. 
Borehole UE-25 WT \#16 was measured periodically during 1999 with Chain \#3. Water levels fluctuated within a 0.09-m range during 1999 (fig. 29) with the lowest water level being $738.31 \mathrm{~m}$ above sea level (04-15-99 and 12-09-99) and the highest water level being $738.40 \mathrm{~m}$ above sea level (07-21-99) (table 15).
The mean water-level altitude of the 1999 data was $738.36 \mathrm{~m}$ above sea level and was within the range of previous annual mean water-level altitudes from 1985 to 1998 (fig. 30). Annual mean water-level altitudes have been rising since 1997 .

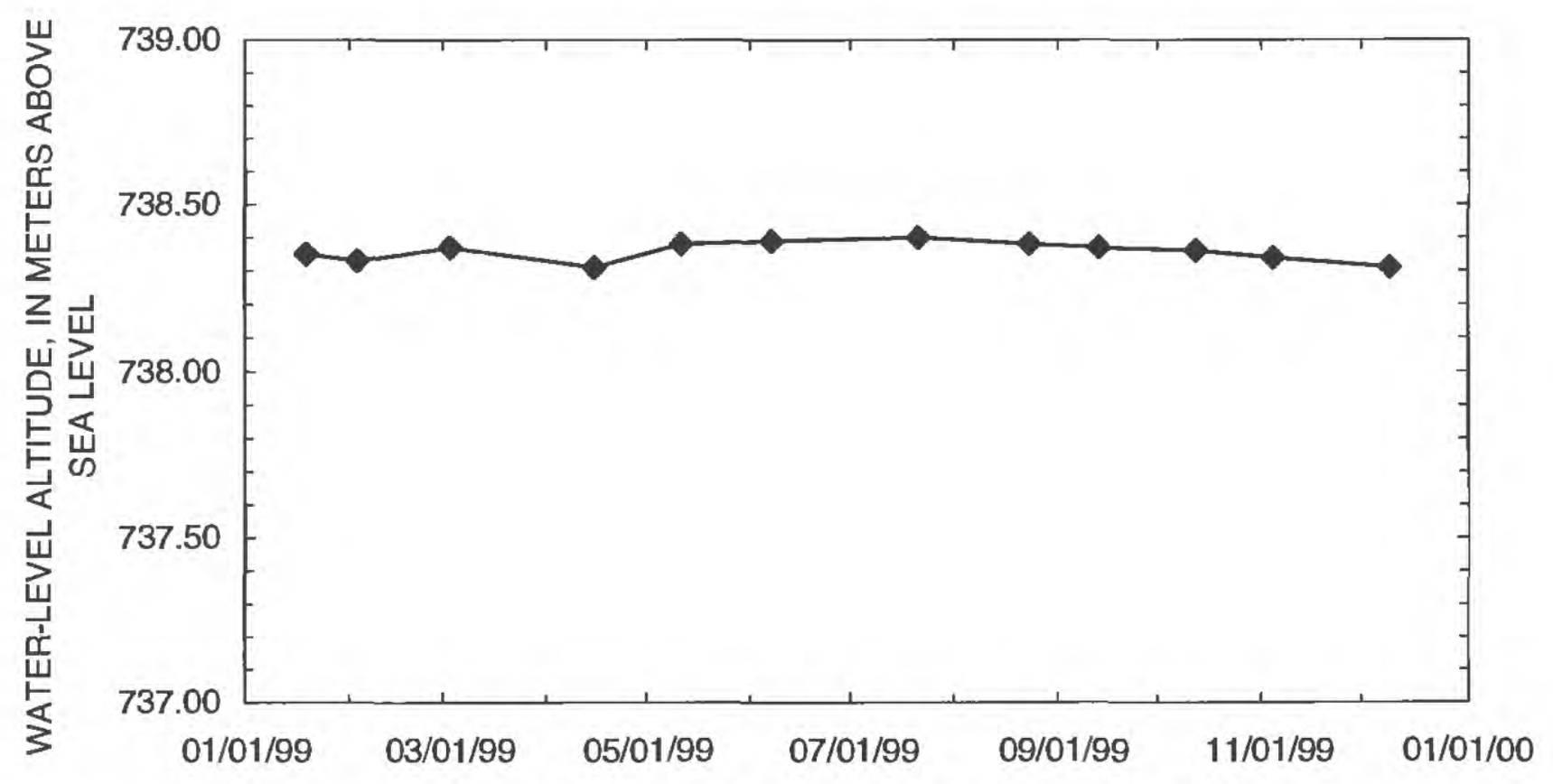

Figure 29. Water-level altitudes for borehole UE-25 WT \#16 during 1999.

Table 15. Measured water-level altitudes, 1999, for borehole UE-25 WT \#16

\begin{tabular}{cccc}
\hline Date & Time & $\begin{array}{c}\text { Water-level eltitude } \\
\text { (meters above see } \\
\text { level) }\end{array}$ & $\begin{array}{c}\text { Equipment } \\
\text { used to } \\
\text { measure water } \\
\text { level }\end{array}$ \\
\hline $01 / 19 / 99$ & 1311 & 738.35 & Chain \#3 \\
$02 / 03 / 99$ & 1215 & 738.33 & Chain \#3 \\
$03 / 03 / 99$ & 1121 & 738.37 & Chain \#3 \\
$04 / 15 / 99$ & 1154 & 738.31 & Chain \#3 \\
$05 / 11 / 99$ & 1055 & 738.38 & Chain \#3 \\
$06 / 07 / 99$ & 1118 & 738.39 & Chain \#3 \\
$07 / 21 / 99$ & 1352 & 738.40 & Chain \#3 \\
$08 / 23 / 99$ & 1233 & 738.38 & Chain \#3 \\
$09 / 13 / 99$ & 1343 & 738.37 & Chain \#3 \\
$10 / 12 / 99$ & 1222 & 738.36 & Chain \#3 \\
$11 / 04 / 99$ & 1419 & 738.34 & Chain \#3 \\
$12 / 09 / 99$ & 1451 & 738.31 & Chain \#3 \\
\hline
\end{tabular}




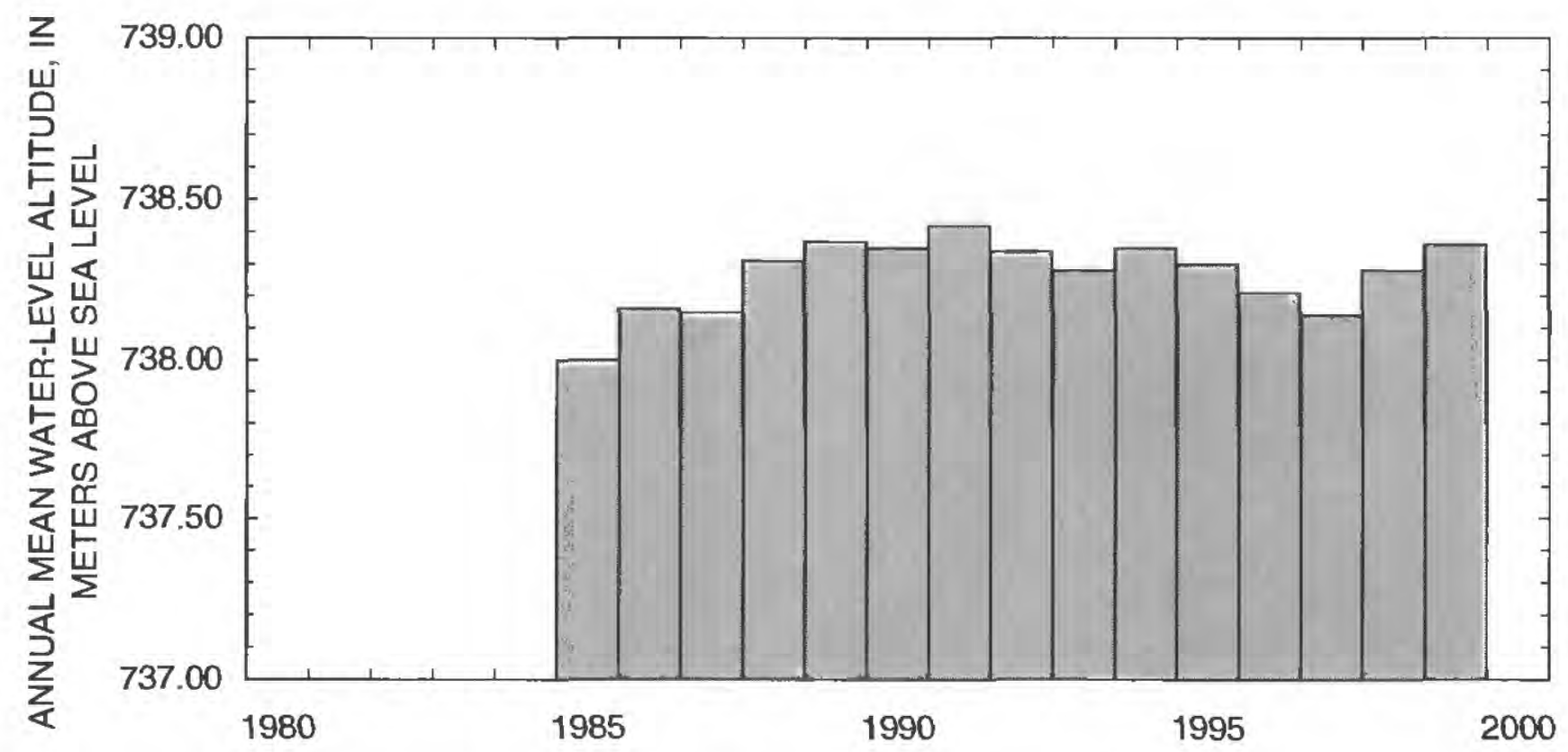

Figure 30. Annual mean water-level altitudes for borehole UE-25 WT \#16.

\section{Borehole UE-25 WT\#17}

\section{Borehole specifications}

\section{Location and identification:}

Nevada State Plane North American Datum of 1927 Central Zone Coordinates (meters): N 228,1 19; E 172,581 (U.S. Department of Energy, written commun., 1999, MO9907YMP99025.001)

Latitude and longitude: $36^{\circ} 48^{\prime} 22^{\prime \prime} \mathrm{N}$.; $116^{\circ} 26^{\prime} 26^{\prime \prime} \mathrm{W}$. (Converted from Nevada State

Plane North American Datum of 1927 Central Zone Coordinates)

U.S. Geological Survey Site ID: 364822116262601.

2. Drilling and casing information:

Borehole started: October 20, 1983 (Fenix \& Scisson, Inc., 1986a, p. 57).

Borehole completed: October 30, 1983 (Fenix \& Scisson, Inc., 1986a, p. 57).

Drilling method: Rotary, using rock bits and airfoam circulating medium; attempt to obtain bottom-hole core unsuccessful, core not obtained from bottom of borehole (Robison and others, 1988, p. 67).

Bit diameter, below land surface: 0 to $16.76 \mathrm{~m}$, $374.65 \mathrm{~mm} ; 16.76$ to $442.87 \mathrm{~m}, 222.25 \mathrm{~mm}$ (Fenix \& Scisson, Inc., 1986a, p. 57).

Casing, below land surface: Surface casing only, to a depth of $16.76 \mathrm{~m}$ (Fenix \& Scisson, Inc., 1986a, p. 57).
Total drilled depth: 442.87 m (Fenix \& Scisson, Inc., 1986a, p. 57).

3. Description of access tube and depth interval for measuring water levels:

January 1, 1997-December 22, 1997: 62-mminside-diameter tubing (Robison and others, 1988 , p. 67) that has a $3.66-\mathrm{m}$-long well screen on the bottom; tubing and attached screen extend from land surface to a depth of 419.40 m (Fenix \& Scisson. Inc.. 1986a, p. 57).

December 22, 1997-July 21, 1998: Workover on borehole so water-quality sampling could be completed. Access tube removed from borehole and replaced during workover.

July 21, 1998: Access tube replaced in borehole: 61.7-mm-inside-diameter fiberglass tubing from 378.43 to $416.47 \mathrm{~m}$ below land surface. Fiberglass tubing slotted (screened) from 411.90 to $416.47 \mathrm{~m}$ below land surface. Bottom of fiberglass tubing is capped. Two drain holes are drilled into the cap. $62.0-\mathrm{mm}$-insidediameter pipe tubing from $378.43 \mathrm{~m}$ to land surface (U.S. Department of Energy, written commun., 1998, MOL19980930.0310).

Saturated interval of borehole is within the Prow Pass Tuff of the Crater Flat Group (Robison and others, 1988, p. 67). Stratigraphic nomenclature presented by Robison revised to agree with stratigraphic nomenclature in Sawyer and others (1994, p. 1305). 
4. Information for calculating water-level altitude:

Reference point: Top of metal tag on well casing. altitude 1,124.06 m (surveyed by U.S. Geological Survey in 1984; Merle E. Southern, National Mapping Division, U.S. Geological Survey, written commun., 1985).

Measurement point: Top of access tubing, $0.408 \mathrm{~m}$ above reference point.

Depth correction for borehole deviation from vertical: Computed from borehole deviation survey dated October 26, 1983 (U.S. Department of Energy, 1994, written commun., MOL.19950516.0160), $-0.482 \mathrm{~m}$, based on approximate depth to water of $395 \mathrm{~m} \mathrm{(1992}$ data) or interpolated directly from borehole deviation survey for the October through December 1999 measurements.

Borehole UE-25 WT \#17 was measured periodically during 1999 with Chain \#3 and the MSMCCU. Water levels fluctuated within a $0.32-\mathrm{m}$ range during 1999 (fig. 31) with the lowest water level being $729.45 \mathrm{~m}$ above sea level (03-18-99) and the highest water level being $729.77 \mathrm{~m}$ above sea level (04-21-99) (table 16). The mean water-level altitude of the 1999 data was $729.66 \mathrm{~m}$ above sea level and was within the range of previous annual mean water-level altitudes from 1985 to 1995 (fig. 32).

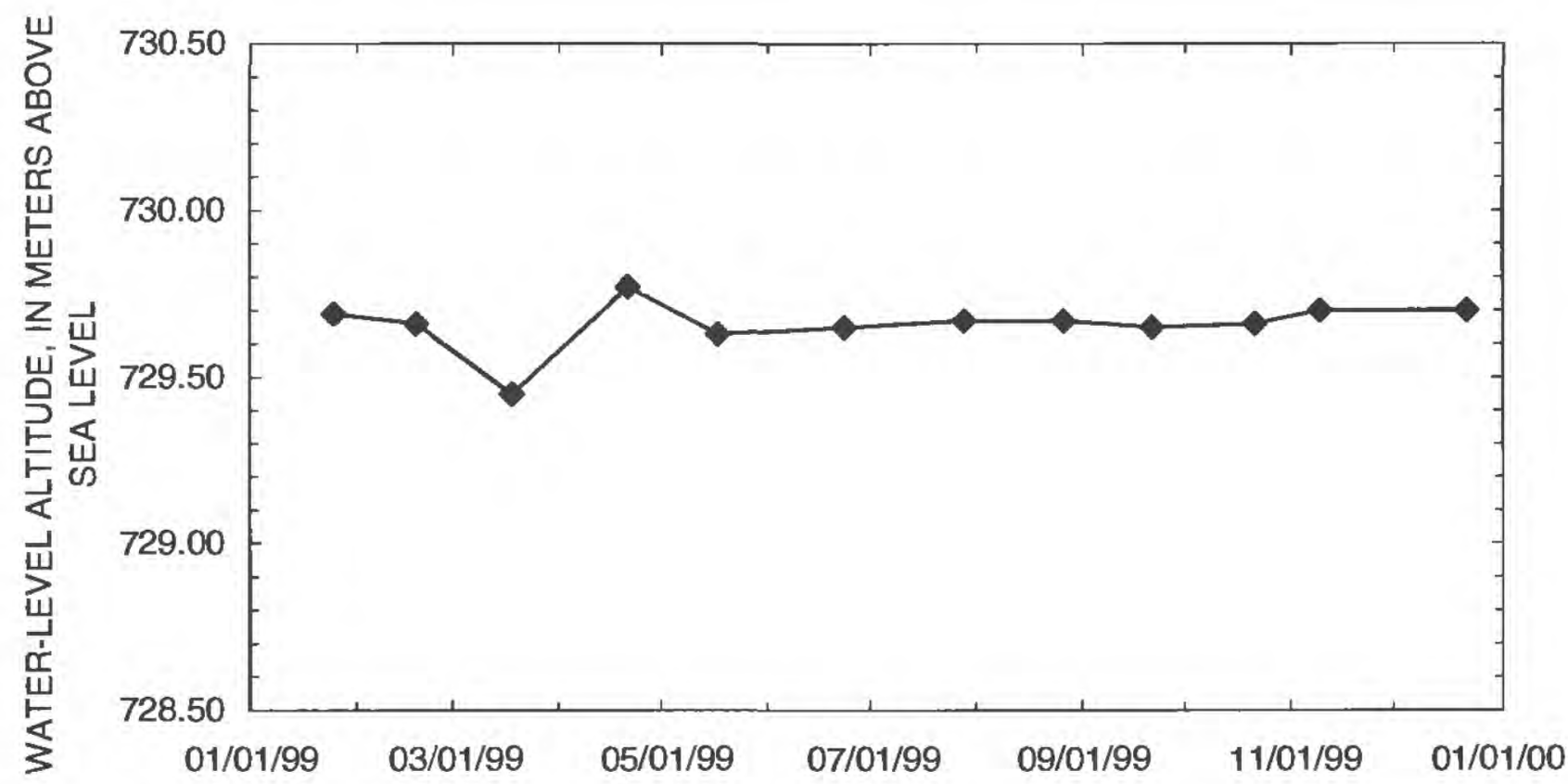

Figure 31. Water-level altitudes for borehole UE-25 WT \#17 during 1999.

Table 16. Measured water-level altitudes, 1999, for borehole UE--25 WT \#17

\begin{tabular}{crcc}
\hline Date & Time & $\begin{array}{c}\text { Water-level altitude } \\
\text { (meters above sea } \\
\text { level) }\end{array}$ & $\begin{array}{c}\text { Equlpment } \\
\text { used to } \\
\text { measure water } \\
\text { level }\end{array}$ \\
\hline $01 / 25 / 99$ & 1608 & 729.69 & Chain \#3 \\
$02 / 18 / 99$ & 943 & 729.66 & Chain \#3 \\
$03 / 18 / 99$ & 1253 & 729.45 & MSMCCU \\
$04 / 21 / 99$ & 1408 & 729.77 & Chain \#3 \\
$05 / 17 / 99$ & 1034 & 729.63 & Chain \#3 \\
$06 / 23 / 99$ & 805 & 729.65 & Chain \#3 \\
$07 / 28 / 99$ & 1414 & 729.67 & Chain \#3 \\
$08 / 26 / 99$ & 1322 & 729.67 & Chain \#3 \\
$09 / 21 / 99$ & 1155 & 729.65 & Chain \#3 \\
$10 / 21 / 99$ & 906 & 729.66 & Chain \#3 \\
$11 / 09 / 99$ & 1518 & 729.70 & Chain \#3 \\
$12 / 22 / 99$ & 1106 & 729.70 & Chain \#3 \\
\hline
\end{tabular}




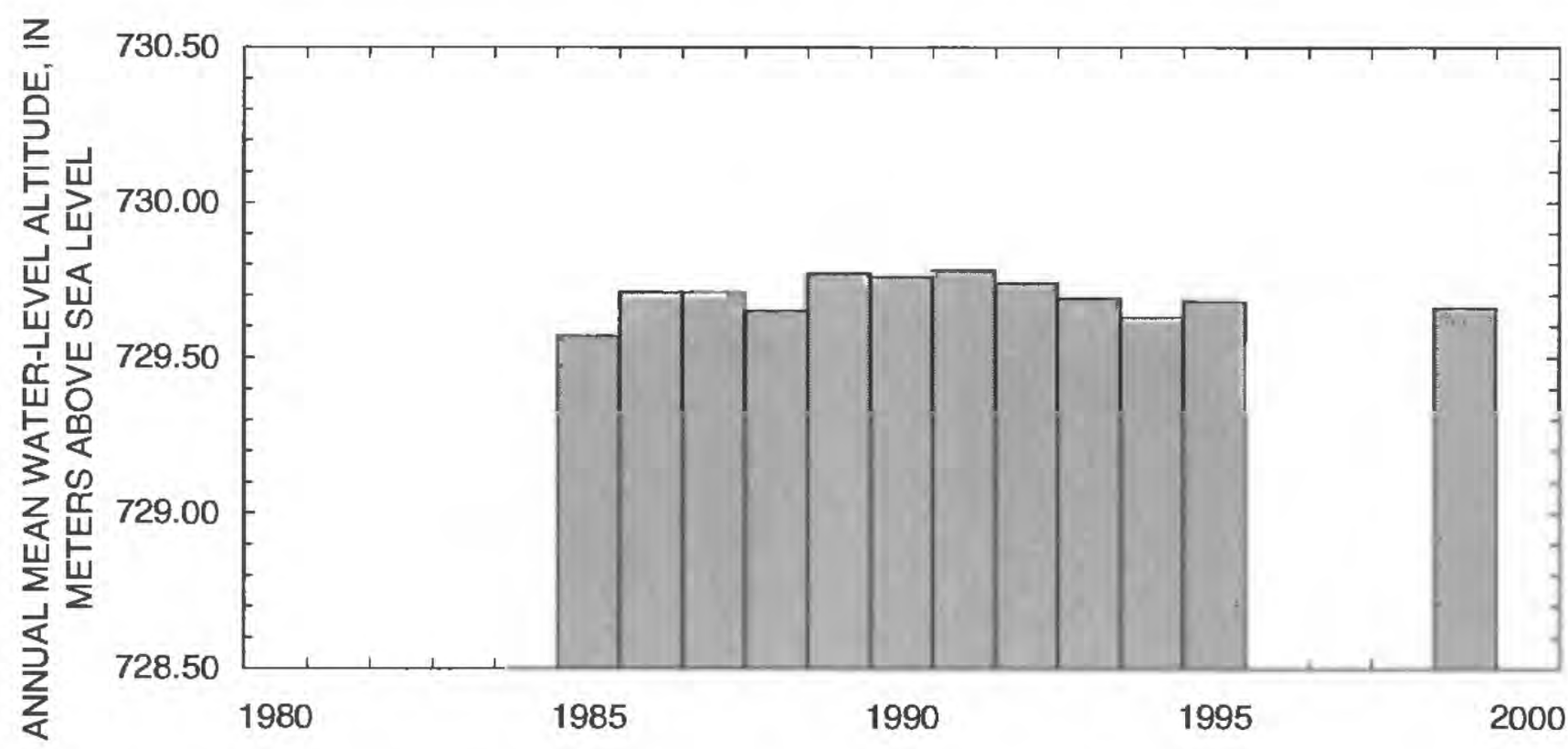

Figure 32. Annual mean water-level altitudes for borehole UE-25 WT \#17.

\section{Borehole USW WT-24}

\section{Borehole specifications}

1. Location and identification:

Nevada State Plane North American Datum of 1927 Central Zone Coordinates (meters): N 236,739; E 171,398 (U.S. Department of Energy, written commun., 1999, MO9907YMP99025.001)

Latitude and longitude: $36^{\circ} 53^{\prime} 01^{\prime \prime} \mathrm{N}$.; $116^{\circ} 27^{\prime} 13^{\prime \prime} \mathrm{W}$. (Converted from Nevada State

Plane North American Datum of 1927 Central Zone Coordinates)

U.S. Geological Survey Site ID: 365301116271301

2. Drilling and casing information:

Borehole started: July 23, 1997 (U.S. Department of Energy, 1997, written commun., MOL.19980128.0478)

Borehole completed: May 14, 1998 (U.S. Department of Energy, 1998, written commun., MOL.19980722.0605)

Drilling method: Air rotary (U.S. Department of Energy, 1998, written commun., MOL.19980722.0605)

Bit diameter, below land surface: 0 to $1.83 \mathrm{~m}$, $660 \mathrm{~mm} ; 1.83$ to $39.3 \mathrm{~m}, 444 \mathrm{~mm} ; 39.3$ to $544.7 \mathrm{~m}, 31 \mathrm{Imm}$; and 544.7 to $863.8 \mathrm{~m}$, 216 mm (U.S. Department of Energy, 1998, written commun., MOL.19980722.0605 and
U.S. Department of Energy, 1997, written commun., MOL.19980128.0478)

Casing, below land surface: 0 to $1.8 \mathrm{~m}, 508 \mathrm{~mm} ; 0$ to $39.1 \mathrm{~m}, 340 \mathrm{~mm}$; and 0 to $544.5 \mathrm{~m}, 244$ mm. (U.S. Department of Energy, 1998, written commun., MOL.19980722.0607)

Total drilled depth: $863.8 \mathrm{~m}$ (U.S. Department of Energy, 1998, written commun., MOL.19980722.0605)

3. Description of access tube and depth interval for measuring water levels:

Open borehole from 544.5 to $863.8 \mathrm{~m}$ accessed through 244-mm-outside-diameter casing.

4. Information for calculating water-level altitude:

Reference point: Dash in stamped borehole name on casing, altitude $1,493.98 \mathrm{~m}, 0.262 \mathrm{~m}$ below top of casing.

Measurement point: Top of casing, altitude 1,494.24 m (U.S. Department of Energy, 1999, written commun., MOL.19990804.0313), $0.262 \mathrm{~m}$ above reference point.

Depth correction for borehole deviation from vertical: Computed from borehole deviation survey dated October 29, 1997 (U.S. Department of Energy, 1997, written commun., MOL.19991201.0364), $-0.085 \mathrm{~m}$, based on approximate depth to water of $653 \mathrm{~m}$ (07-141998 data) or interpolated directly from borehole deviation survey for the October through December 1999 measurements. 
Borehole USW WT-24 was measured periodically during 1999 with the MSMCCU. Water levels fluctuated within a 1.00-m range during 1999 (fig. 33) with the lowest water level being $839.73 \mathrm{~m}$ above sea level (05-18-99) and the highest water level being $840.73 \mathrm{~m}$ above sea level (09-23-99) (table 17). The mean water-level altitude of the 1999 data was $840.07 \mathrm{~m}$ above sea level.

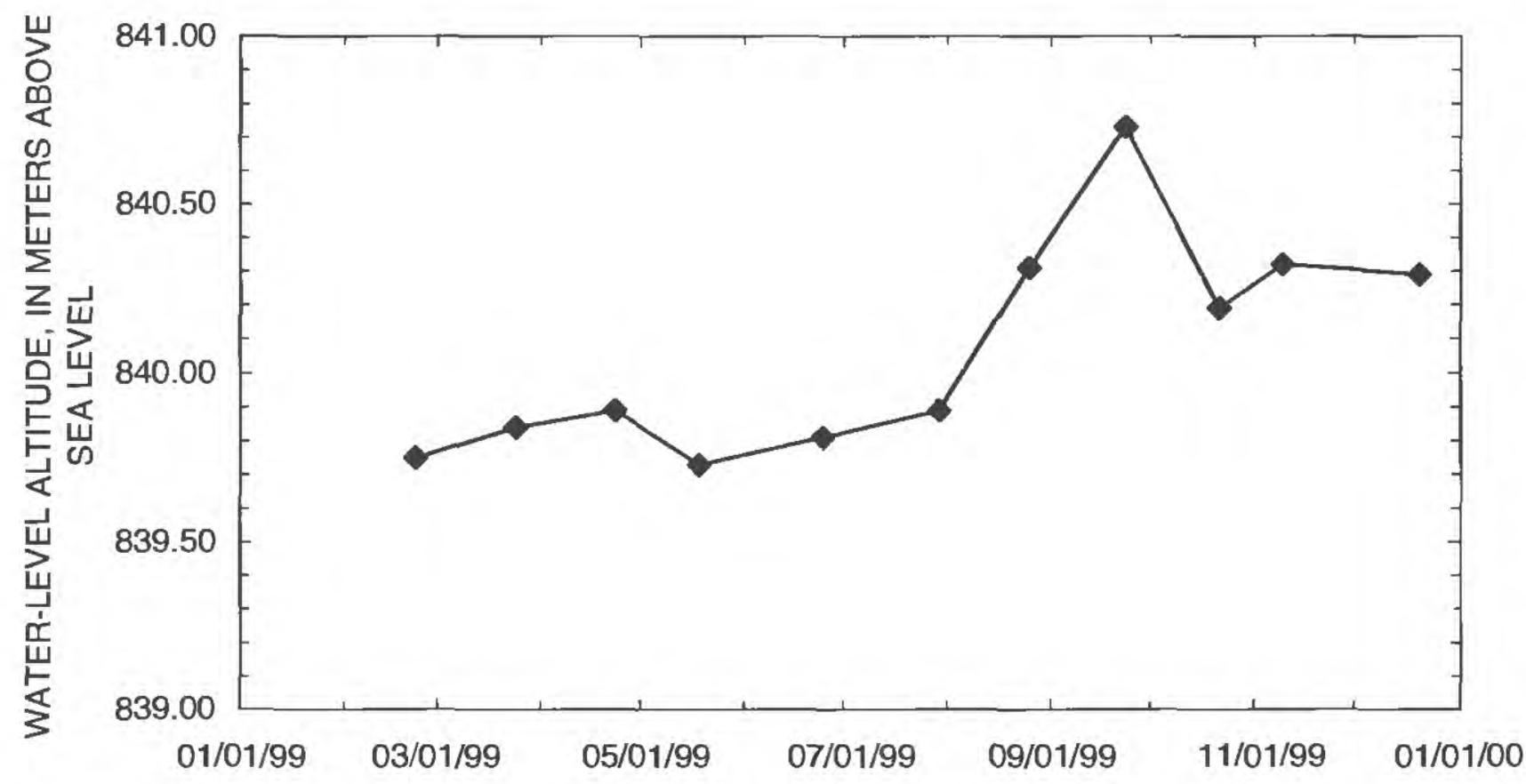

Figure 33. Water-level altitudes for borehole USW WT-24 during 1999.

Table 17. Measured water-level altitudes, 1999, for borehole USW WT-24

\begin{tabular}{crcc}
\hline Date & Time & $\begin{array}{c}\text { Water-level altitude } \\
\text { (meters above sea } \\
\text { level) }\end{array}$ & $\begin{array}{c}\text { Equipment } \\
\text { used to } \\
\text { measure water } \\
\text { level }\end{array}$ \\
\hline $02 / 22 / 99$ & 1205 & 839.75 & MSMCCU \\
$03 / 24 / 99$ & 1010 & 839.84 & MSMCCU \\
$04 / 23 / 99$ & 906 & 839.89 & MSMCCU \\
$05 / 18 / 99$ & 1003 & 839.73 & MSMCCU \\
$06 / 24 / 99$ & 933 & 839.81 & MSMCCU \\
$07 / 29 / 99$ & 1315 & 839.89 & MSMCCU \\
$08 / 25 / 99$ & 1240 & 840.31 & MSMCCU \\
$09 / 23 / 99$ & 1110 & 840.73 & MSMCCU \\
$10 / 21 / 99$ & 1114 & 840.19 & MSMCCU \\
$11 / 09 / 99$ & 1120 & 840.32 & MSMCCU \\
$12 / 20 / 99$ & 1032 & 840.29 & MSMCCU \\
\hline
\end{tabular}




\section{Borehole UE-25 p \#1}

\section{Borehole specifications}

1. Location and identification:

Nevada State Plane North American Datum of 1927 Central Zone Coordinates (meters): N 230,481; E 174, 188 (U.S. Department of Energy, written commun., 1999, MO9907YMP99025.001)

Latitude and longitude: $36^{\circ} 49^{\prime} 38^{\prime \prime} \mathrm{N}$.; $116^{\circ} 25^{\prime} 21^{\prime \prime W}$. (Converted from Nevada State Plane North American Datum of 1927 Central Zone Coordinates)

U.S. Geological Survey Site ID: 364938116252102.

2. Drilling and casing information:

Borehole started: November 13, 1982 (Fenix \& Scisson, Inc., 1986b, p. 3).

Borehole completed: May 24, 1983 (Fenix \& Scisson, Inc., 1986b, p. 3).

Drilling method: Rotary, using rock bits and airfoam circulating medium; cores obtained from selected intervals (Robison and others, 1988, p. 82).

Bit diameter, below land surface: 0 to $12.80 \mathrm{~m}$, $762.00 \mathrm{~mm} ; 12.80$ to $103.02 \mathrm{~m}, 558.80 \mathrm{~mm}$; 103.02 to $103.94 \mathrm{~m}, 444.50 \mathrm{~mm} ; 103.94$ to $487.07 \mathrm{~m}, 374.65 \mathrm{~mm} ; 487.07$ to $1,304.24 \mathrm{~m}$, $250.83 \mathrm{~mm} ; 1,304.24$ to $1,317.35 \mathrm{~m}$, $174.63 \mathrm{~mm} ; 1,317.35$ to $1,798.32 \mathrm{~m}$, $171.45 \mathrm{~mm} ; 1,798.32$ to $1,805.33 \mathrm{~m}$, $155.58 \mathrm{~mm}$ (Fenix \& Scisson, Inc., 1986b, p. 3).

Casing, below land surface: 0 to $10.97 \mathrm{~m}$, 590.5-mm-inside-diameter; 0 to $99.06 \mathrm{~m}$, 384.18 - $\mathrm{mm}$ inside diameter; 0 to $476.71 \mathrm{~m}$, 255.27-mm-inside-diameter; 453.24 to 1,297.23 m, 177.01-mm-inside-diameter (Fenix \& Scisson, Inc., 1986b, p. 3).

Total drilled depth: 1,805.33 m (Fenix \& Scisson, Inc., 1986b, p. 3).

3. Description of access tube and depth interval for measuring water levels:

January 1-October 31, 1997; a 38-mm-insidediameter tubing (Robison and others, 1988, p. 82), open ended, to depth of $417.88 \mathrm{~m}$ (Fenix \& Scisson, Inc., 1986b, p. 3). Borehole construction is such that water level in the tuffs of Tertiary age is not monitored. Only the water level in the underlying carbonate rocks of Paleozoic age is measured. Tertiary-Paleozoic contact is at 1,244 $\mathrm{m}$ (Robison and others, 1988, p. 82).

January 1-October 31, 1997; a 38-mm-insidediameter tubing, closed end, filled with water, set to a depth of $413 \mathrm{~m}$ below land surface also is installed in the borehole to allow access for temperature logging (Robison and others, 1988, p. 82).

After October 31, 1997, a workover was completed on borehole UE-25 p\#1 and both tubes were removed from the borehole. The same tubes were placed back in the borehole during November 1997. The exact depth of each tube after November 1997 is not reported; however, borehole UE-25 p\#1 still monitors only the water level in the carbonate rocks of Paleozoic age.

4. Information for calculating water-level altitude:

Reference point: Top of metal tag on well casing; altitude $1,114.21 \mathrm{~m}$ (surveyed by U.S. Geological Survey in 1984; Merle E. Southern. National Mapping Division, U.S. Geological Survey, written commun., 1985).

Measurement point: Top of access tube, $0.183 \mathrm{~m}$ above reference point. Access tube removed and replaced during October-November 1997.

Depth correction for borehole deviation from vertical: Computed from borehole deviation survey dated May 3, 1983 (U.S. Department of Energy, 1984, written commun., NNA.19890509.0026), $-0.021 \mathrm{~m}$, based on approximate depth to water of $361 \mathrm{~m}(1992$ data) or interpolated directly from borehole deviation survey for the October through December 1999 measurements.

Borehole UE-25 p \#1 was measured periodically during 1999 with Chain \#3. Water levels fluctuated within a 0.16-m range during 1999 (fig. 34) with the lowest water level being $752.83 \mathrm{~m}$ above sea level (11-08-99) and the highest water level being $752.99 \mathrm{~m}$ above sea level (10-06-99) (table 18). The mean water-level altitude of the 1999 data was $752.93 \mathrm{~m}$ above sea level and was a new maximum annual mean water-level altitude in comparison to the range of previous annual mean water-level altitudes from 1985 to 1998 (fig. 35). Annual mean water-level altitudes have been rising since 1992 . 


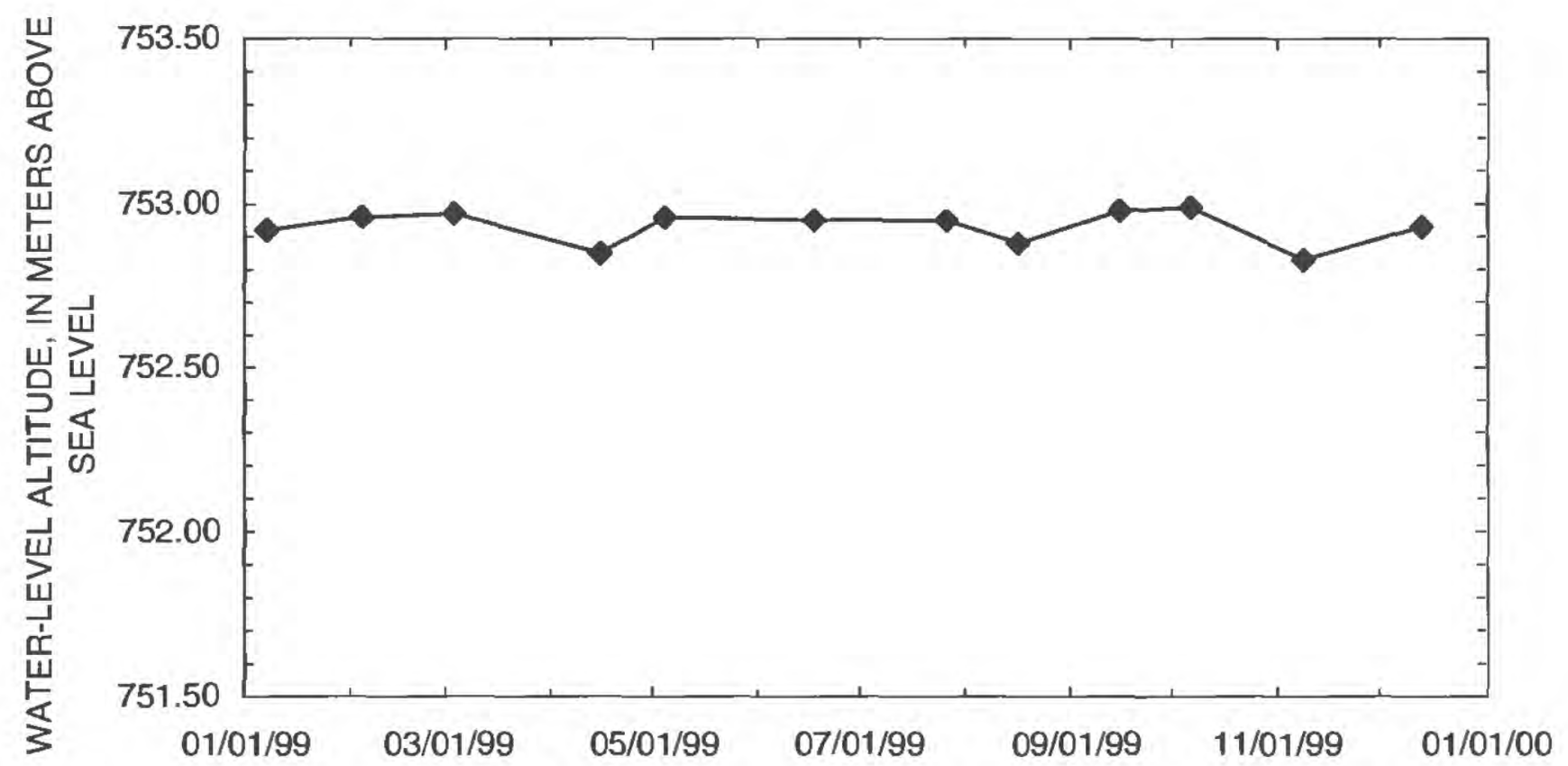

Figure 34. Water-level altitudes for borehole UE-25 p \#1 during 1999.

Table 18. Measured water-level altitudes, 1999, for borehole UE-25 p \#1

\begin{tabular}{cccc}
\hline Date & Time & $\begin{array}{c}\text { Water-level altitude } \\
\text { (meters above sea } \\
\text { level) }\end{array}$ & $\begin{array}{c}\text { Equipment } \\
\text { used to } \\
\text { measure water } \\
\text { level }\end{array}$ \\
\hline $01 / 07 / 99$ & 1508 & 752.92 & Chain \#3 \\
$02 / 04 / 99$ & 1053 & 752.96 & Chain \#3 \\
$03 / 03 / 99$ & 1416 & 752.97 & Chain \#3 \\
$04 / 15 / 99$ & 1341 & 752.85 & Chain \#3 \\
$05 / 04 / 99$ & 1143 & 752.96 & Chain \#3 \\
$06 / 17 / 99$ & 1152 & 752.95 & Chain \#3 \\
$07 / 26 / 99$ & 1402 & 752.95 & Chain \#3 \\
$08 / 16 / 99$ & 1547 & 752.88 & Chain \#3 \\
$09 / 15 / 99$ & 942 & 752.98 & Chain \#3 \\
$10 / 06 / 99$ & 1056 & 752.99 & Chain \#3 \\
$11 / 08 / 99$ & 1249 & 752.83 & Chain \#3 \\
$12 / 13 / 99$ & 1237 & 752.93 & Chain \#3 \\
\hline
\end{tabular}

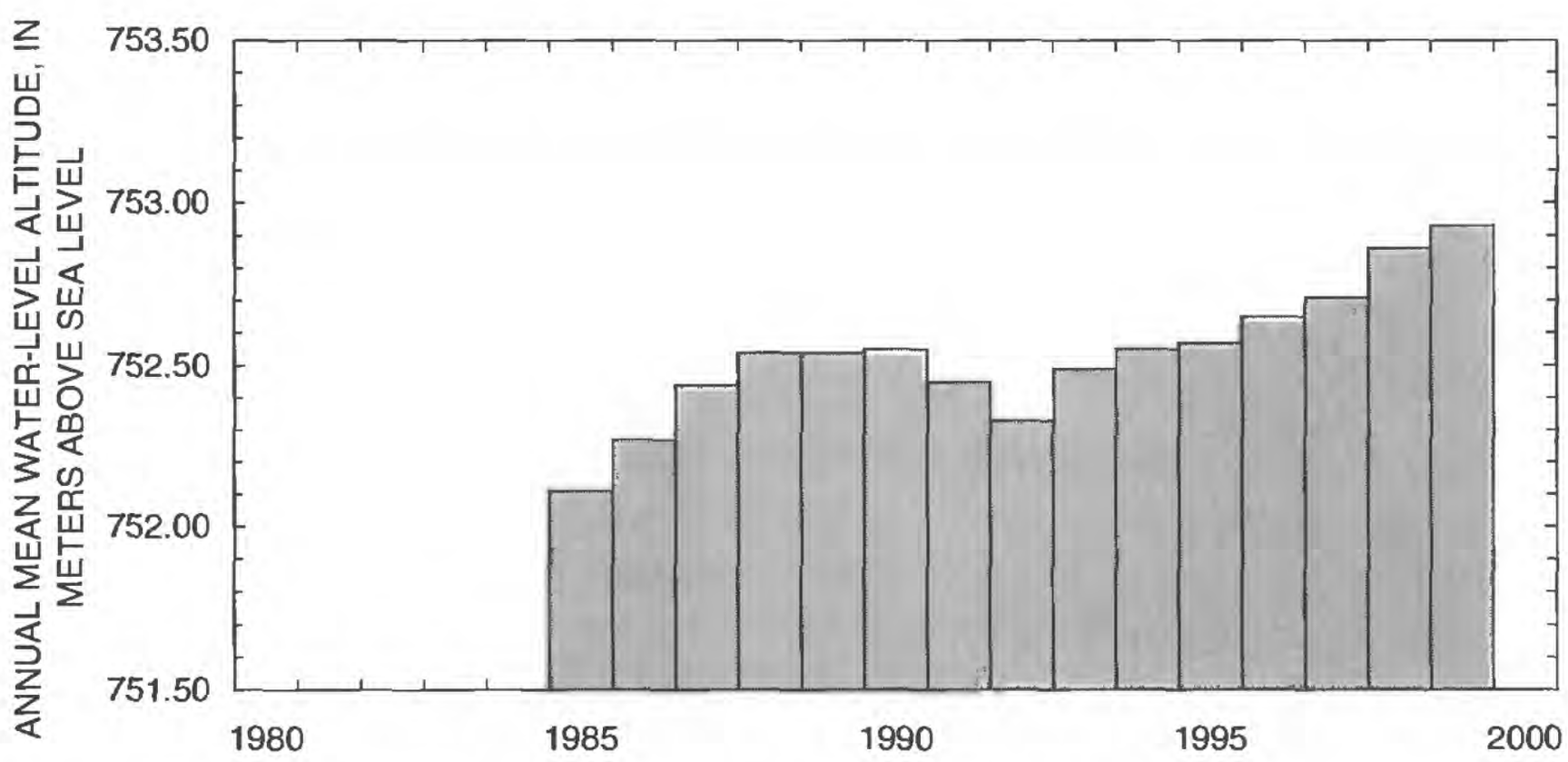

Figure 35. Annual mean water-level altitudes for borehole UE-25 $p$ \#1. 


\section{Borehole USW G-2}

\section{Borehole specifications}

1. Location and identification:

Nevada State Plane North American Datum of

1927 Central Zone Coordinates (meters):

N 237,386; E 170.842 (U.S. Department of

Energy, written commun., 1999, MO9907YMP99025.001)

Latitude and longitude: $36^{\circ} 53^{\prime} 22^{\prime \prime} \mathrm{N}$.; $116^{\circ} 27^{\prime} 35^{\prime \prime W}$. (Converted from Nevada State Plane North American Datum of 1927 Central Zone Coordinates)

U.S. Geological Survey Site ID: 365322116273501 .

2. Drilling and casing information:

Borehole started: March 25, 1981 (Robison and others, 1988, p. 85).

Borehole completed: October 24, 1981 (Robison and others, 1988, p. 85).

Drilling method: Rotary, using rock bits with polymer mud to $88 \mathrm{~m}$; cored and reamed from $88 \mathrm{~m}$ to total depth; polymer mud and air foam used as needed to total depth (Robison and others, 1988, p. 85).

Bit diameter, below land surface: $222 \mathrm{~mm}$ to $814 \mathrm{~m} ; 159 \mathrm{~mm}$ from $814 \mathrm{~m}$ to $947 \mathrm{~m} ; 156$ $\mathrm{mm}$ from 947 to $1,439 \mathrm{~m} ; 76 \mathrm{~mm}$ from 1,439 $\mathrm{m}$ to total depth (Robison and others, 1988, p. 85).

Casing, below land surface extending below water level: None (surface casing, 320-mm-insidediameter, 0 to $85 \mathrm{~m}$, and 276-mm-inside-diameter, 0 to $242 \mathrm{~m}$ ) (Robison and others, 1988, p. 85).

Total drilled depth: 1,831 m (Robison and others, 1988, p. 85).

3. Description of access tube and depth interval for measuring water levels:

Saturated interval of borehole is within the

Topopah Spring Tuff of the Paintbrush Group; the Calico Hills Formation; Prow Pass, Bullfrog, and Tram Tuffs of the Crater Flat Group; Lithic Ridge Tuff; and older flows and tuffs (Robison and others. 1988, p. 85). Stratigraphic nomenclature presented by Robison revised to agree with stratigraphic nomenclature in Sawyer and others (1994, p. 1305).
An inflatable packer was set at a depth of $792 \mathrm{~m}$ below land surface on September 28, 1995.

The packer was set to isolate a bridge plug previously set in the borehole at $808 \mathrm{~m}$ below land surface (O'Brien, 1998, p. 7).

During October 1995, a 60.33-mm-inside-diameter access tube extending from land surface to $582.01 \mathrm{~m}$ below land surface was installed in borehole USW G-2. The bottom of the tube was capped with a 3.28 -m-long well screen above the cap (U.S. Department of Energy, written commun.. 1995, MOL.19971007.0615). This access tube was removed from borehole USW G-2 during July 1997 so a pump that was in the borehole could be removed. Two new access tubes were installed in the borehole on September 4 and 5,1997 . One access tube is capped and extends to $578.75 \mathrm{~m}$ below land surface with a 2.93-m-long slotted pipe (well screen) above the cap. The inside diameter of the tube is not reported. The second access tube is capped and extends to $582.26 \mathrm{~m}$ below land surface with a well screen above the cap. Neither the length of well screen or inside diameter of the tube is reported (U.S. Department of Energy, written commun., 1997,

MOL.19980806.0384). Either of these access tubes might have been used for water-level measurements during 1999.

4. Information for calculating water-level altitude:

Reference point: Top of metal tag on well casing, altitude $1,553.86 \mathrm{~m}$ (surveyed by U.S. Geological Survey in 1984; Merle E. Southern, National Mapping Division, U.S. Geological Survey, written commun., 1985).

Measurement point: Top of access tube, January I-July 1997, $0.56 \mathrm{~m}$ above reference point. September 4, 1997-December 31, 1998, two new tubes, the measuring point of one is $0.268 \mathrm{~m}$ above the reference point, the measuring point of the other is $0.226 \mathrm{~m}$ above the reference point.

Depth correction for borehole deviation from vertical: Computed from borehole deviation survey dated October $13,1981,-0.192 \mathrm{~m}$, based on approximate depth to water of 534 m (1994 data) or interpolated directly from borehole deviation survey for the October through December 1999 measurements. 
Borehole USW G-2 was measured periodically during 1999 with Chain \#3. Water levels fluctuated within a $0.20-\mathrm{m}$ range during 1999 (fig. 36) with the lowest water level being $1019.34 \mathrm{~m}$ above sea level (02-11-99) and the highest water level being $1019.54 \mathrm{~m}$ above sea level (03-11-99) (table 19). The mean water-level altitude of the 1999 data was $1019.44 \mathrm{~m}$ above sea level and was within the range of previous annual mean water-level altitudes from 1992 to 1998 (fig. 37). The annual mean water-level altitude declined from 1998.

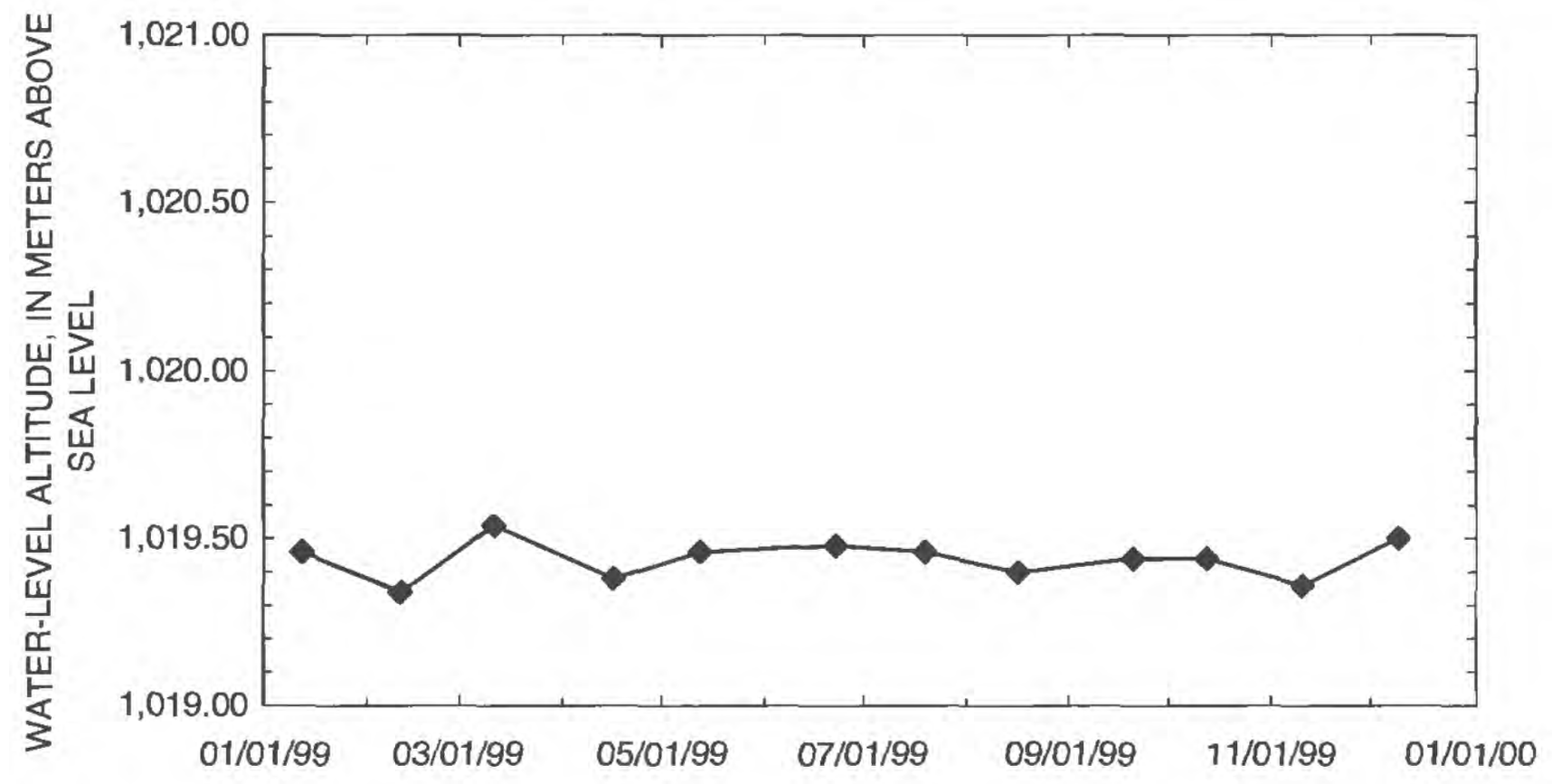

Figure 36. Water-level altitudes for borehole USW G-2 during 1999.

Table 19. Measured water-level altitudes, 1999, for borehole USW G-2

\begin{tabular}{crcc}
\hline Date & Time & $\begin{array}{c}\text { Water-level altitude } \\
\text { (meters above sea } \\
\text { level) }\end{array}$ & $\begin{array}{c}\text { Equipment } \\
\text { used to } \\
\text { measure water } \\
\text { level }\end{array}$ \\
\hline $01 / 12 / 99$ & 930 & 1.019 .46 & Chain \#3 \\
$02 / 11 / 99$ & 1024 & $1,019.34$ & Chain \#3 \\
$03 / 11 / 99$ & 1336 & $1,019.54$ & Chain \#3 \\
$04 / 16 / 99$ & 926 & $1,019.38$ & Chain \#3 \\
$05 / 12 / 99$ & 940 & $1,019.46$ & Chain \#3 \\
$06 / 22 / 99$ & 1107 & $1,019.48$ & Chain \#3 \\
$07 / 19 / 99$ & 1314 & $1,019.46$ & Chain \#3 \\
$08 / 16 / 99$ & 1336 & $1,019.40$ & Chain \#3 \\
$09 / 20 / 99$ & 1034 & 1.019 .44 & Chain \#3 \\
$10 / 12 / 99$ & 933 & 1.019 .44 & Chain \#3 \\
$11 / 10 / 99$ & 940 & $1,019.36$ & Chain \#3 \\
$12 / 09 / 99$ & 1213 & $1,019.50$ & Chain \#3 \\
\hline
\end{tabular}




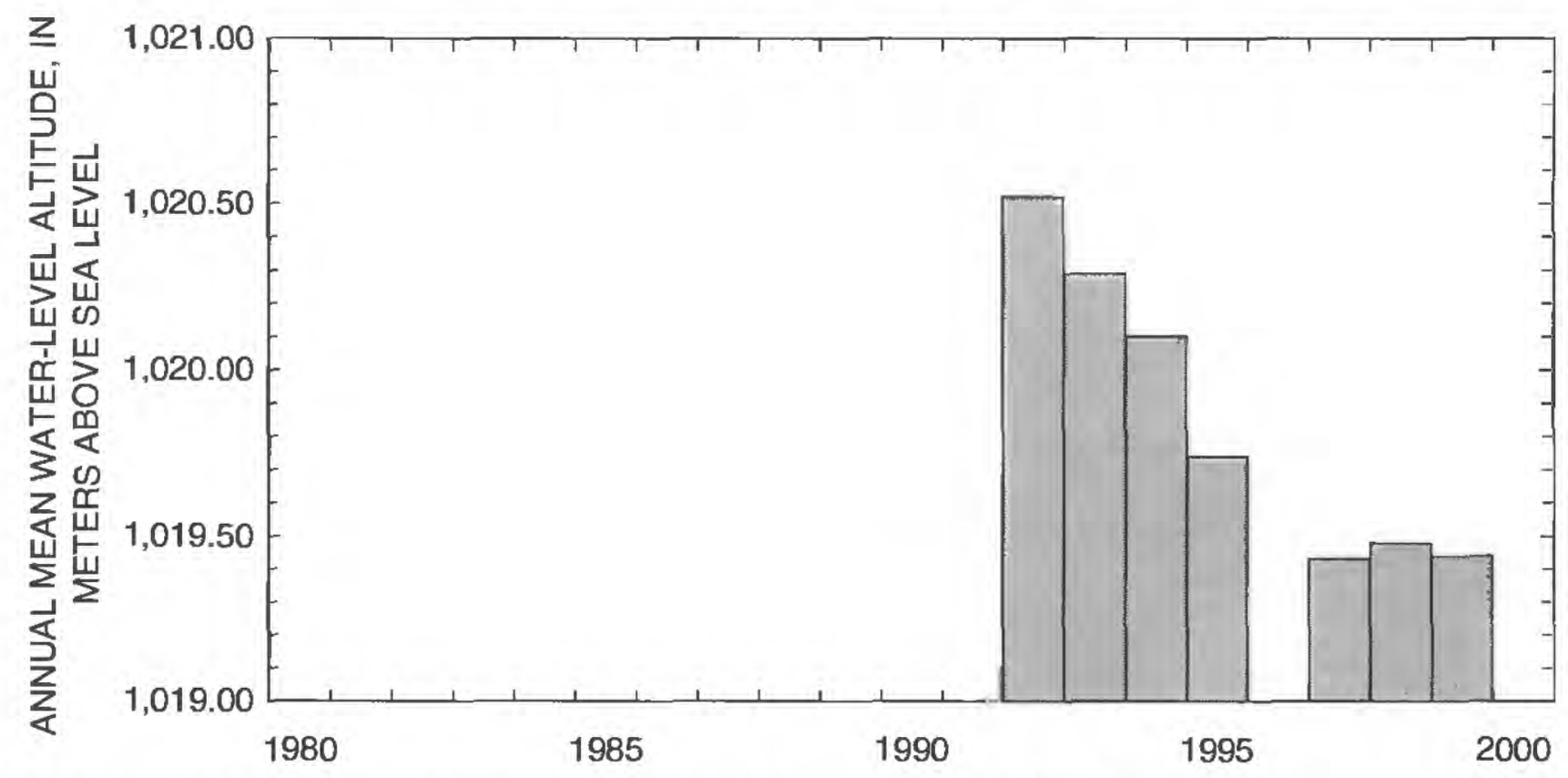

Figure 37. Annual mean water-level altitudes for borehole USW G-2.

\section{Borehole USW H-1}

\section{Borehole specifications}

1. Location and identification:

Nevada State Plane North American Datum of 1927 Central Zone Coordinates (meters): N 234,774; E 171,416 (U.S. Department of Energy, written commun., 1999, MO9907YMP99025.001)

Latitude and longitude: $36^{\circ} 51^{\prime} 58^{\prime \prime} \mathrm{N}$.; $116^{\circ} 27^{\prime} 12^{\prime \prime} W$. (Converted from Nevada State Plane North American Datum of 1927 Central Zone Coordinates)

U.S. Geological Survey Site ID:

365157116271201 (entire borehole), 365157116271202 (Tube 1), 365157116271203 (Tube 2), 365157116271204 (Tube 3), and 365157116271205 (Tube 4).

2. Drilling and casing information:

Borehole started: September 3, 1980 (Fenix \& Scisson, Inc., 1987a, p. 3).

Borehole completed: January 25, 1981; borehole completion, however access tubes not installed (Fenix \& Scisson, Inc., 1987a, p. 3, and 5-14);

Workover of borehole, four piezometers installed June 21, 1982, to July 6, 1982 (Fenix \& Scisson, Inc., 1987a, p. 15 and 16).

Drilling method: Rotary, using rock bits and airfoam circulating medium; cores obtained from selected intervals (Robison and others, 1988. p. 93).

Bit diameter, below land surface: 0 to $3.05 \mathrm{~m}$, 1,219.20 mm: 3.05 to $12.50 \mathrm{~m}, 1.181 .1 \mathrm{~mm}$; 12.50 to $102.11 \mathrm{~m}, 508 \mathrm{~mm} ; 102.11$ to 117.04 m, $381 \mathrm{~mm} ; 117.04$ to $530.35 \mathrm{~m}, 336.55 \mathrm{~mm}$; 530.35 to $687.93 \mathrm{~m}, 311.15 \mathrm{~mm} ; 687.93$ to 1,828.8 m, 222.25 mm (Fenix \& Scisson, Inc., 1987a, p. 3).

Casing: 0 to $687.32 \mathrm{~m}$ (Fenix \& Scisson, Inc., 1987a, p. 3).

Total drilled depth: $1.828 .80 \mathrm{~m}$ (Fenix \& Scisson, Inc., 1987a, p. 3).

3. Description of access tube and depth interval for measuring water levels:

Tube 1: 44-mm-inside-diameter tubing (Robison and others, 1988, p. 93), extending from land surface to a depth of $1,805.90 \mathrm{~m}$ with a screen of $3.72 \mathrm{~m}$ in length on the bottom (Fenix \& Scisson, Inc., 1987a, p. 15). Tube monitors a depth interval of 1,783 to $1,814 \mathrm{~m}$ within older flows and tuffs beneath the Lithic Ridge Tuff (Robison and others, 1988, p. 93). Stratigraphic nomenclature presented by Robison revised to agree with stratigraphic nomenclature in Sawyer and others (1994, p. 1305).

Tube 2: 44-mm-inside-diameter tubing (Robison and others, 1988, p. 93), extending from land surface to a depth of $1,114.65 \mathrm{~m}$ with a screen of $3.72 \mathrm{~m}$ in length on the bottom (Fenix \& Scisson, Inc., 1987a, p. 15 and 16). Tube monitors a depth interval of 1,097 to $1,123 \mathrm{~m}$ within the Tram Tuff of the Crater Flat Group and lava flow and flow breccia beneath the Tram Tuff; (Robison and others, 1988, p. 93). Stratigraphic nomenclature presented by Robison revised to agree with stratigraphic nomenclature in Sawyer and others (1994. p. 1305).

Tube 3: 44-mm-inside-diameter tubing (Robison and others, 1988, p. 93), extending from land 
surface to a depth of $741.11 \mathrm{~m}$ with a screen of $3.72 \mathrm{~m}$ in length on the bottom (Fenix \& Scisson, Inc., 1987a, p. 15 and 16). Tube monitors a depth interval of 716 to $765 \mathrm{~m}$ within the Bullfrog Tuff of the Crater Flat Group (Robison and others, 1988, p. 93). Stratigraphic nomenclature presented by Robison revised to agree with stratigraphic nomenclature in Sawyer and others (1994, p. 1305).

Tube 4: 62-mm-inside-diameter tubing (Robison and others, 1988, p. 93), extending from land surface to depth of $640.08 \mathrm{~m}$; tubing is open ended (Fenix \& Scisson, Inc., 1987a, p. 16). Tube monitors a depth interval of 572 to 673 $m$ within the Prow Pass Tuff of the Crater Flat Group (Robison and others, 1988, p. 93). Stratigraphic nomenclature presented by Robison revised to agree with stratigraphic nomenclature in Sawyer and others (1994, p. 1305).

Note: During the June 21, 1982, to July 6, 1982 borehole workover, a gravel pack was placed in the vicinity of the well screens for tubes 1 , 2 , and 3; other intervals were grouted with cement to ensure that the tubes are hydraulically isolated from each other (Fenix \& Scisson, Inc., 1987a, p. 15 and 16).

4. Information for calculating water-level altitude:

Reference point: Top of metal tag on well casing; altitude $1,303.10 \mathrm{~m}$ (surveyed by U.S. Geological Survey in 1984; Merle E. Southern, National Mapping Division, U.S. Geological Survey, written commun., 1985).

Measurement point: Top of access tubes, $0.311 \mathrm{~m}$ above reference point, all intervals.

Depth correction for borehole deviation from vertical: Computed from borehole deviation survey dated November 22, 1980 (U.S. Department of Energy, 1980, written commun., NNA.19890810.0017), $-0.143 \mathrm{~m}$ in tube 1, based on approximate depth to water of $518 \mathrm{~m}$ (1992 data); $-0.171 \mathrm{~m}$ in tube 2 , based on approximate depth to water of $567 \mathrm{~m}$ (1992 data); $-0.174 \mathrm{~m}$ in tubes 3 and 4 , based on approximate depths to water of $572 \mathrm{~m} \mathrm{(1992}$ data) or interpolated directly from borehole deviation survey for the October through December 1999 measurements.

Tube 1: Borehole USW H-1 Tube I was measured periodically during 1999 with Chain \#3. Water levels fluctuated within a $0.48 \mathrm{~m}$ range during 1999 (fig. 38) with the lowest water level being $785.74 \mathrm{~m}$ above sea level (12-08-99) and the highest water level being $786.22 \mathrm{~m}$ above sea level (06-15-99) (table 20). The mean water-level altitude of the 1999 data was $786.08 \mathrm{~m}$ above sed level and was within the range of previous annual mean water-level altitudes from 1985 to 1998 (fig. 39). The annual mean water-level altitude declined from 1998.

Tube 2: Borehole USW H-1, Tube 2 was measured periodically during 1999 with Chain \#3. Water levels fluctuated within a $0.13-\mathrm{m}$ range during 1999 (fig. 40) with the lowest water level being $735.00 \mathrm{~m}$ above sea level (08-16-99) and the highest water level being $735.13 \mathrm{~m}$ above sea level (01-25-99) (table 21). The mean water-level altitude of the 1999 data was $735.05 \mathrm{~m}$ above sea level and was less than the range of previous annual mean water-level altitudes from 1985 to 1998 (fig. 41). Annual mean water-level altitudes have declined since 1990.

Tube 3: Borehole USW H-1, Tube 3 was measured periodically during 1999 with Chain \#3. Water levels fluctuated within a $0.21-\mathrm{m}$ range during 1999 (fig. 42) with the lowest water level being $730.62 \mathrm{~m}$ above sea level (08-16-99) and the highest water level being $730.83 \mathrm{~m}$ above sea level (01-25-99) (table 22). The mean water-level altitude of the 1999 data was $730.70 \mathrm{~m}$ above sea level and was within the range of previous annual mean water-level altitudes from 1985 to 1998 (fig. 43). Annual mean water-level altitudes have been rising since 1997 .

Tube 4: Borehole USW H-1, Tube 4 was measured periodically during 1999 with Chain \#3. Water levels fluctuated within a $0.23-\mathrm{m}$ range during 1999 (fig. 44) with the lowest water level being $730.74 \mathrm{~m}$ above sea level (07-19-99) and the highest water level being $730.97 \mathrm{~m}$ above sea level (01-25-99)

(table 23). The mean water-level altitude of the 1999 data was $730.85 \mathrm{~m}$ above sea level and was within the range of previous annual mean water-level altitudes from 1985 to 1998 (fig. 45). Annual mean water-level altitudes have been rising since 1997 . 


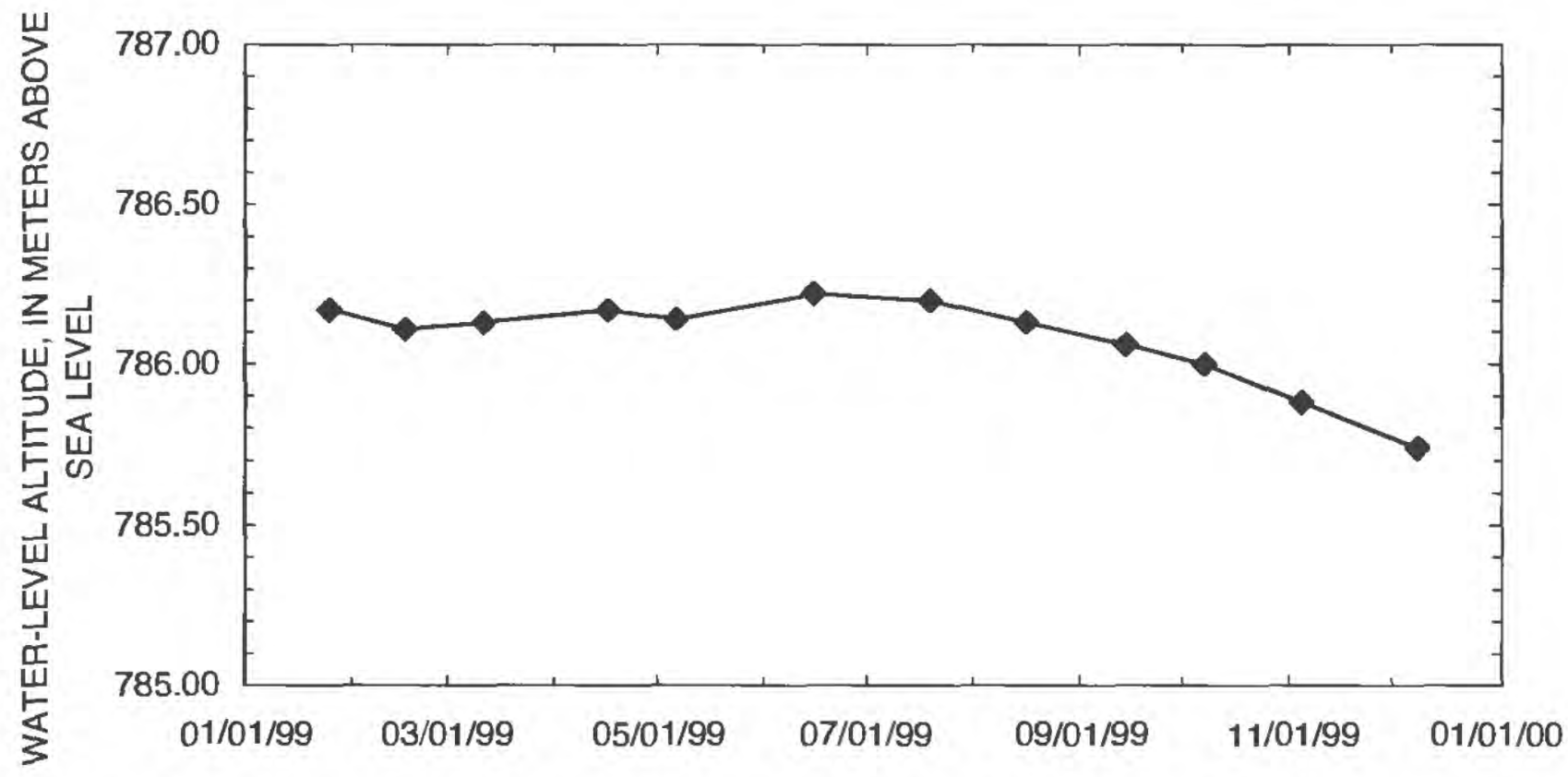

Figure 38. Water-level altitudes for borehole USW H-1, tube 1, during 1999.

Table 20. Measured water-level altitudes, 1999, for borehole USW H-1, tube 1

\begin{tabular}{crcc}
\hline Date & Time & $\begin{array}{c}\text { Water-level altitude } \\
\text { (meters above sea } \\
\text { level) }\end{array}$ & $\begin{array}{c}\text { Equipment } \\
\text { used to } \\
\text { measure water } \\
\text { level }\end{array}$ \\
\hline $01 / 25 / 99$ & 917 & 786.17 & Chain \#3 \\
$02 / 16 / 99$ & 1025 & 786.11 & Chain \#3 \\
$03 / 11 / 99$ & 1023 & 786.13 & Chain \#3 \\
$04 / 16 / 99$ & 1031 & 786.17 & Chain \#3 \\
$05 / 06 / 99$ & 1155 & 786.14 & Chain \#3 \\
$06 / 15 / 99$ & 914 & 786.22 & Chain \#3 \\
$07 / 19 / 99$ & 1003 & 786.20 & Chain \#3 \\
$08 / 16 / 99$ & 1057 & 786.13 & Chain \#3 \\
$09 / 14 / 99$ & 859 & 786.06 & Chain \#3 \\
$10 / 07 / 99$ & 939 & 786.00 & Chain \#3 \\
$11 / 04 / 99$ & 1005 & 785.88 & Chain \#3 \\
$12 / 08 / 99$ & 1130 & 785.74 & Chain \#3 \\
\hline
\end{tabular}

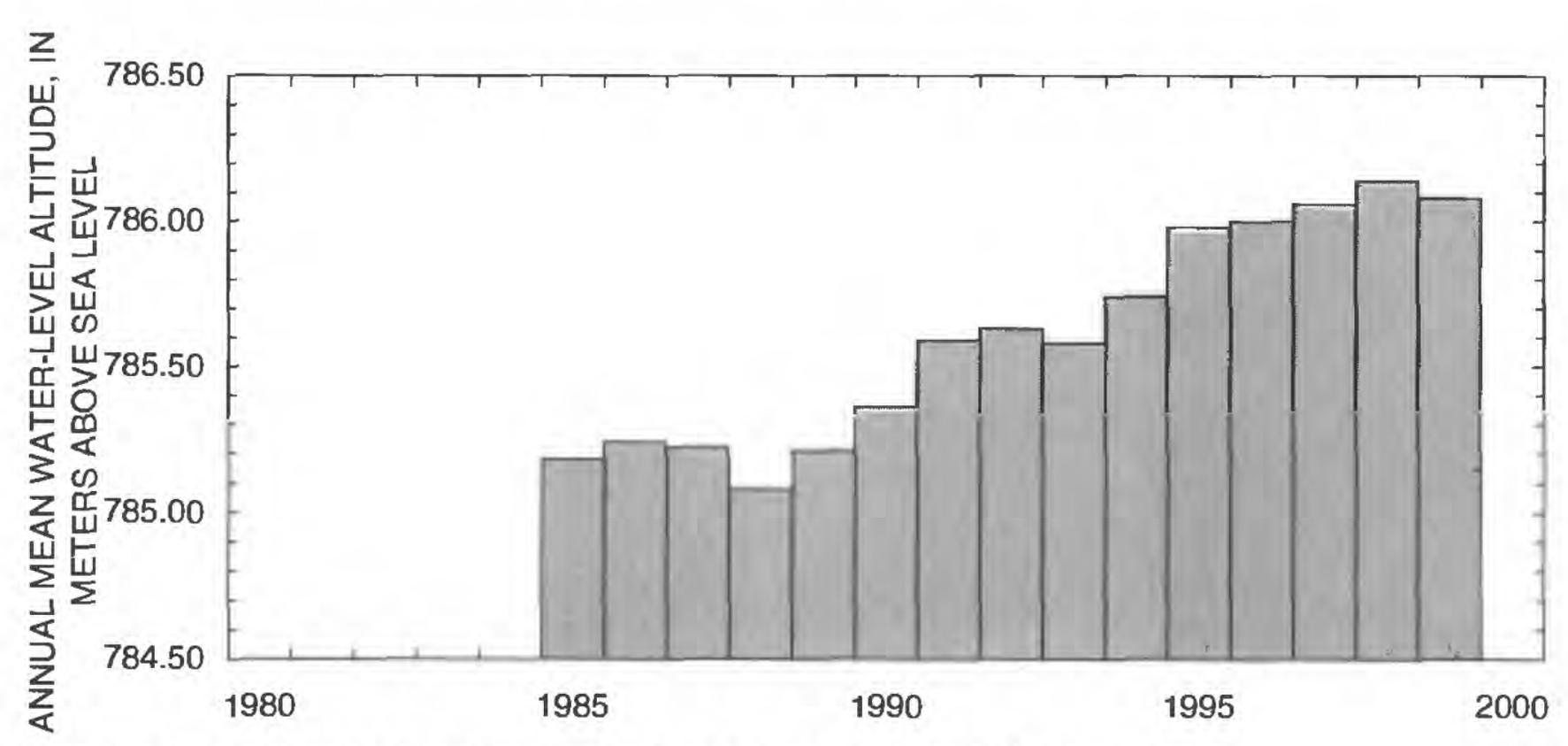

Figure 39. Annual mean water-level altitudes for borehole USW H-1, tube 1. 


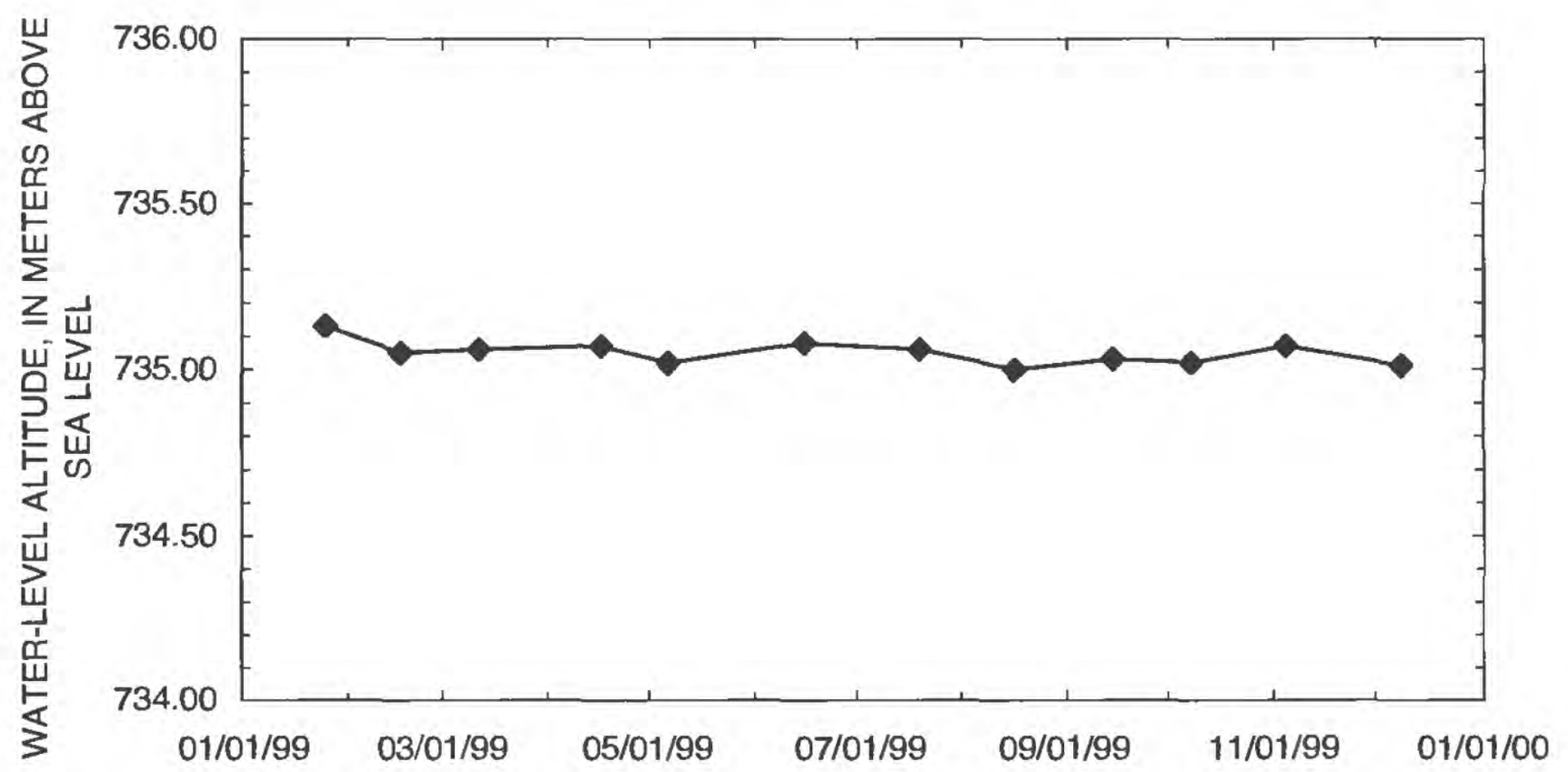

Figure 40. Water-level altitudes for borehole USW H-1, tube 2 during 1999.

Table 21. Measured water-level altitudes, 1999, for borehole USW H-1, tube 2

\begin{tabular}{crcc}
\hline Date & Time & $\begin{array}{c}\text { Water-level altitude } \\
\text { (meters above sea } \\
\text { level) }\end{array}$ & $\begin{array}{c}\text { Equipment } \\
\text { used to } \\
\text { measure water } \\
\text { level }\end{array}$ \\
\hline $01 / 25 / 99$ & 957 & 735.13 & Chain \#3 \\
$02 / 16 / 99$ & 1102 & 735.05 & Chain \#3 \\
$03 / 11 / 99$ & 1054 & 735.06 & Chain \#3 \\
$04 / 16 / 99$ & 1101 & 735.07 & Chain \#3 \\
$05 / 06 / 99$ & 1225 & 735.02 & Chain \#3 \\
$06 / 15 / 99$ & 944 & 735.08 & Chain \#3 \\
$07 / 19 / 99$ & 1032 & 735.06 & Chain \#3 \\
$08 / 16 / 99$ & 1125 & 735.00 & Chain \#3 \\
$09 / 14 / 99$ & 935 & 735.03 & Chain \#3 \\
$10 / 07 / 99$ & 1010 & 735.02 & Chain \#3 \\
$11 / 04 / 99$ & 1058 & 735.07 & Chain \#3 \\
$12 / 08 / 99$ & 1203 & 735.01 & Chain \#3 \\
\hline
\end{tabular}

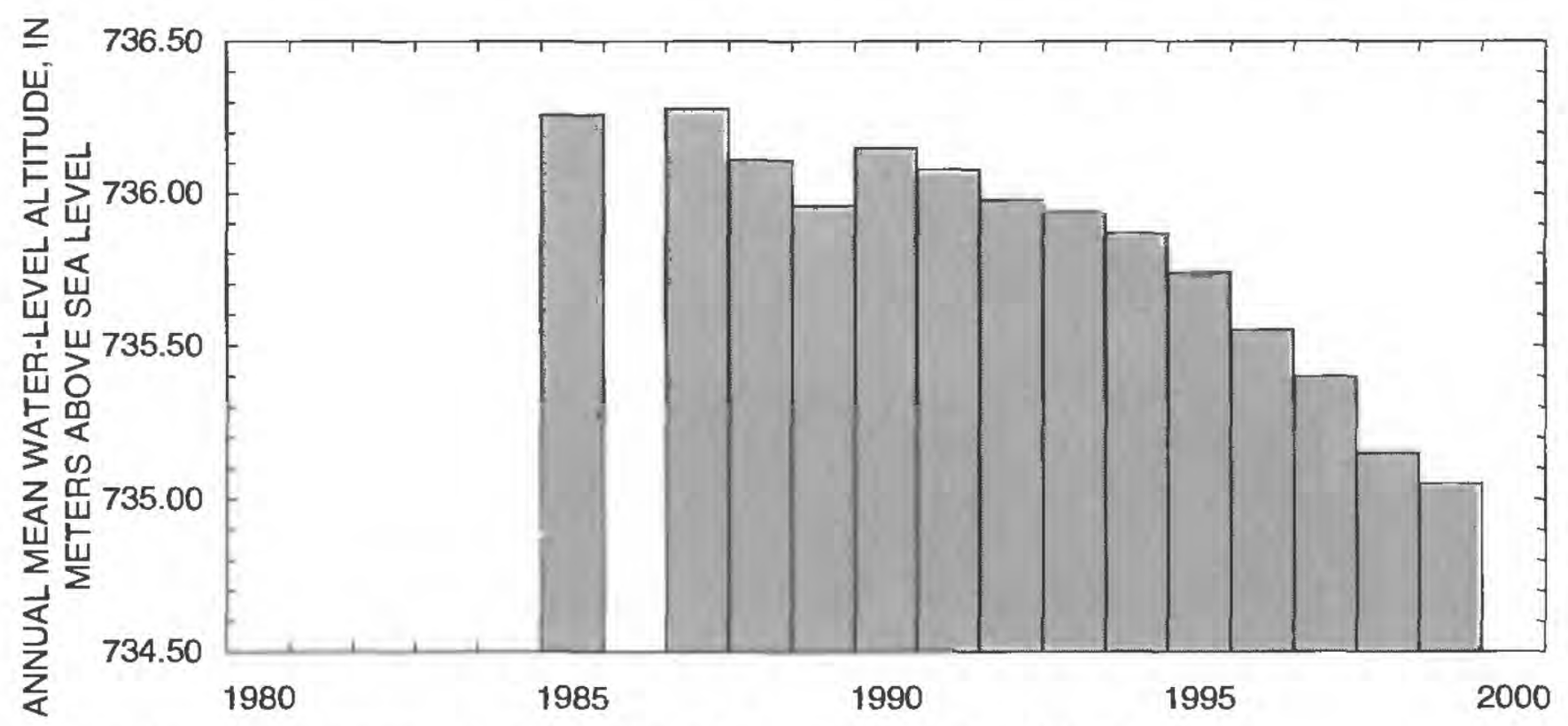

Figure 41. Annual mean water-level altitudes for borehole USW H-1, tube 2. 


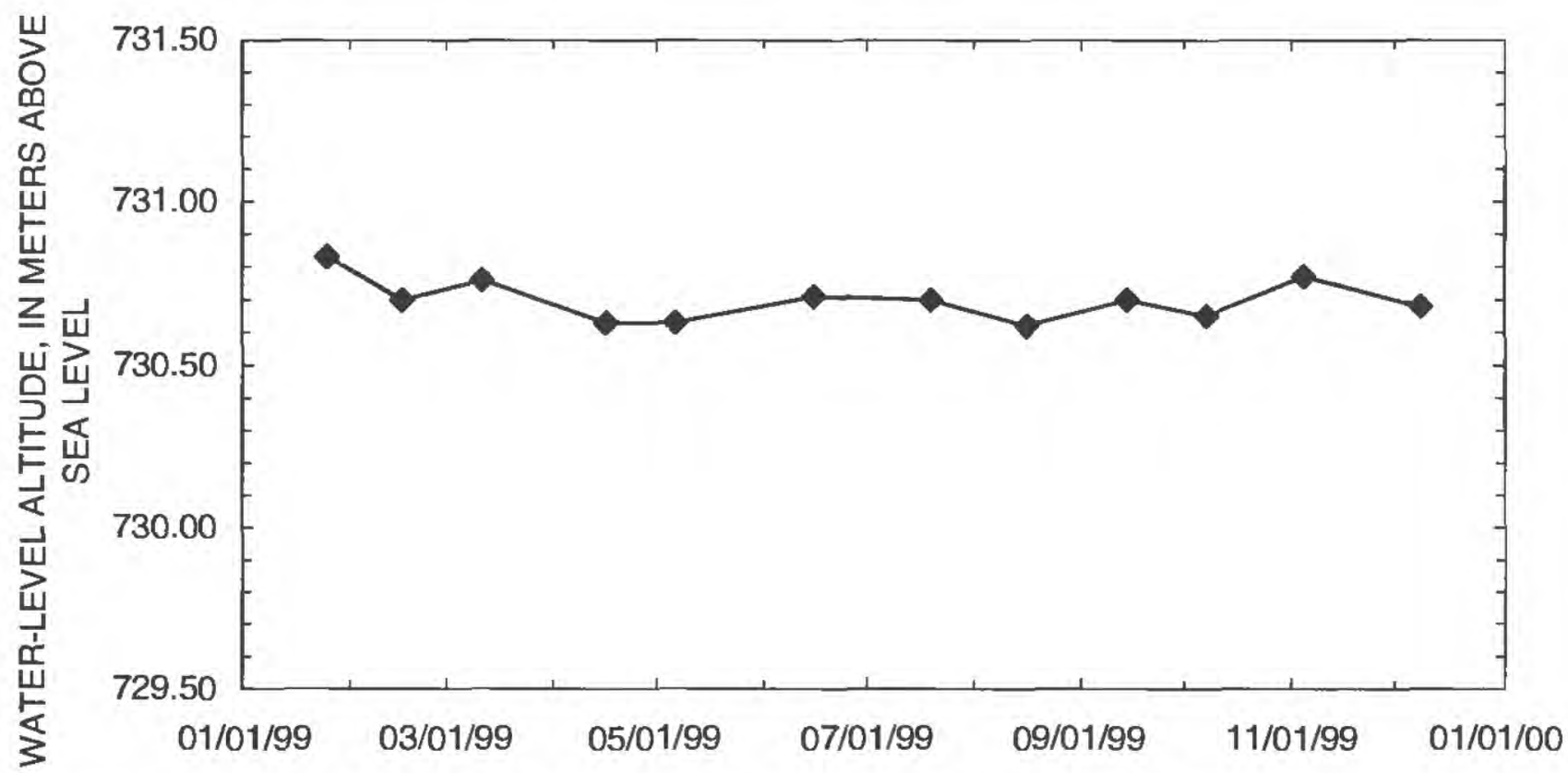

Figure 42. Water-level altitudes for borehole USW H-1, tube 3, during 1999.

Table 22. Measured water-level altitudes, 1999, for borehole USW $\mathrm{H}-1$, tube 3

\begin{tabular}{cccc}
\hline Date & Time & $\begin{array}{c}\text { Water-level altitude } \\
\text { (meters above sea } \\
\text { level) }\end{array}$ & $\begin{array}{c}\text { Equipment } \\
\text { used to } \\
\text { measure water } \\
\text { level }\end{array}$ \\
\hline $01 / 25 / 99$ & 1036 & 730.83 & Chain \#3 \\
$02 / 16 / 99$ & 1140 & 730.70 & Chain \#3 \\
$03 / 11 / 99$ & 1124 & 730.76 & Chain \#3 \\
$04 / 16 / 99$ & 1132 & 730.63 & Chain \#3 \\
$05 / 06 / 99$ & 1256 & 730.63 & Chain \#3 \\
$06 / 15 / 99$ & 1013 & 730.71 & Chain \#3 \\
$07 / 19 / 99$ & 1102 & 730.70 & Chain \#3 \\
$08 / 16 / 99$ & 1153 & 730.62 & Chain \#3 \\
$09 / 14 / 99$ & 1007 & 730.70 & Chain \#3 \\
$10 / 07 / 99$ & 1041 & 730.65 & Chain \#3 \\
$11 / 04 / 99$ & 1134 & 730.77 & Chain \#3 \\
$12 / 08 / 99$ & 1237 & 730.68 & Chain \#3 \\
\hline
\end{tabular}

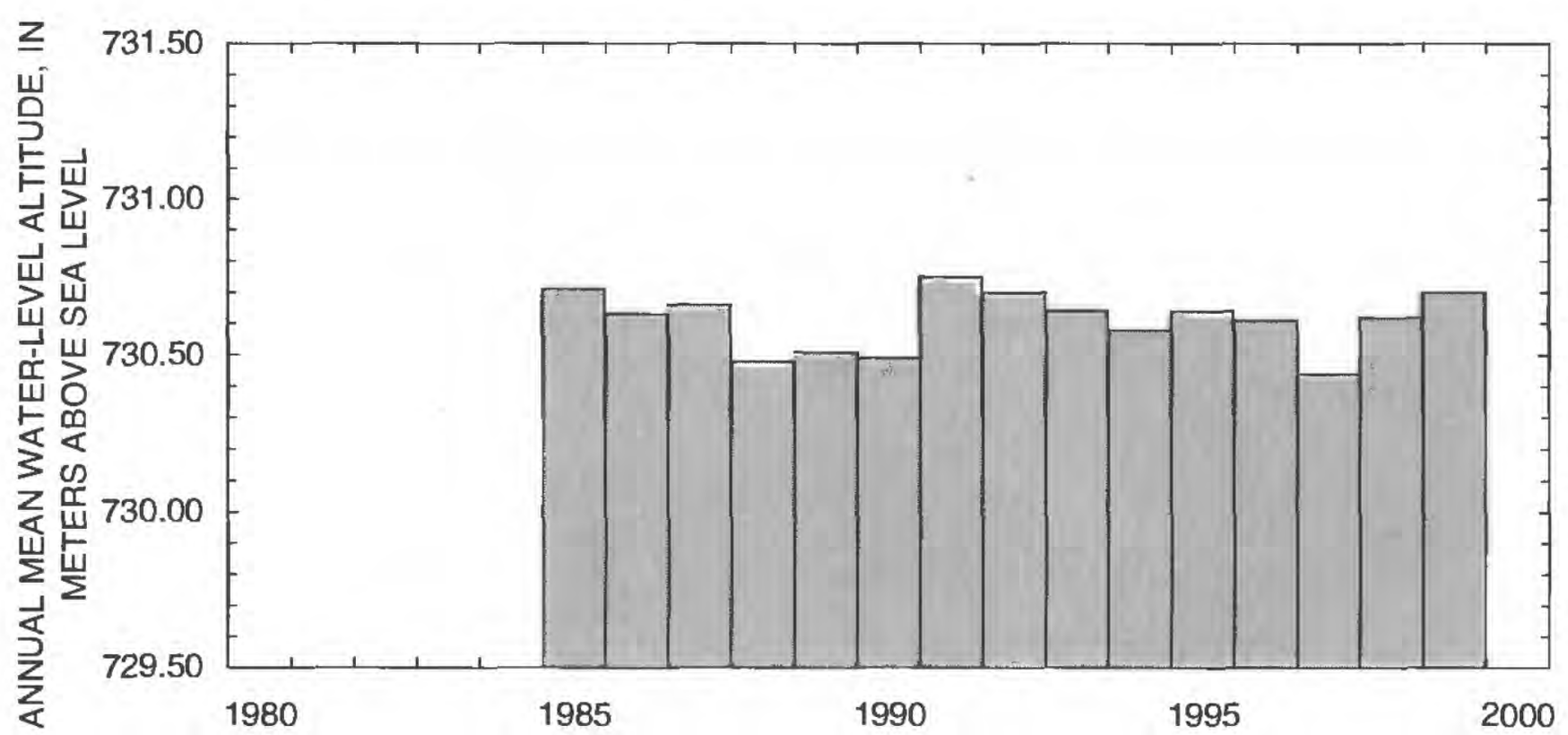

Figure 43. Annual mean water-level altitudes for borehole USW $\mathrm{H}-1$, tube 3. 


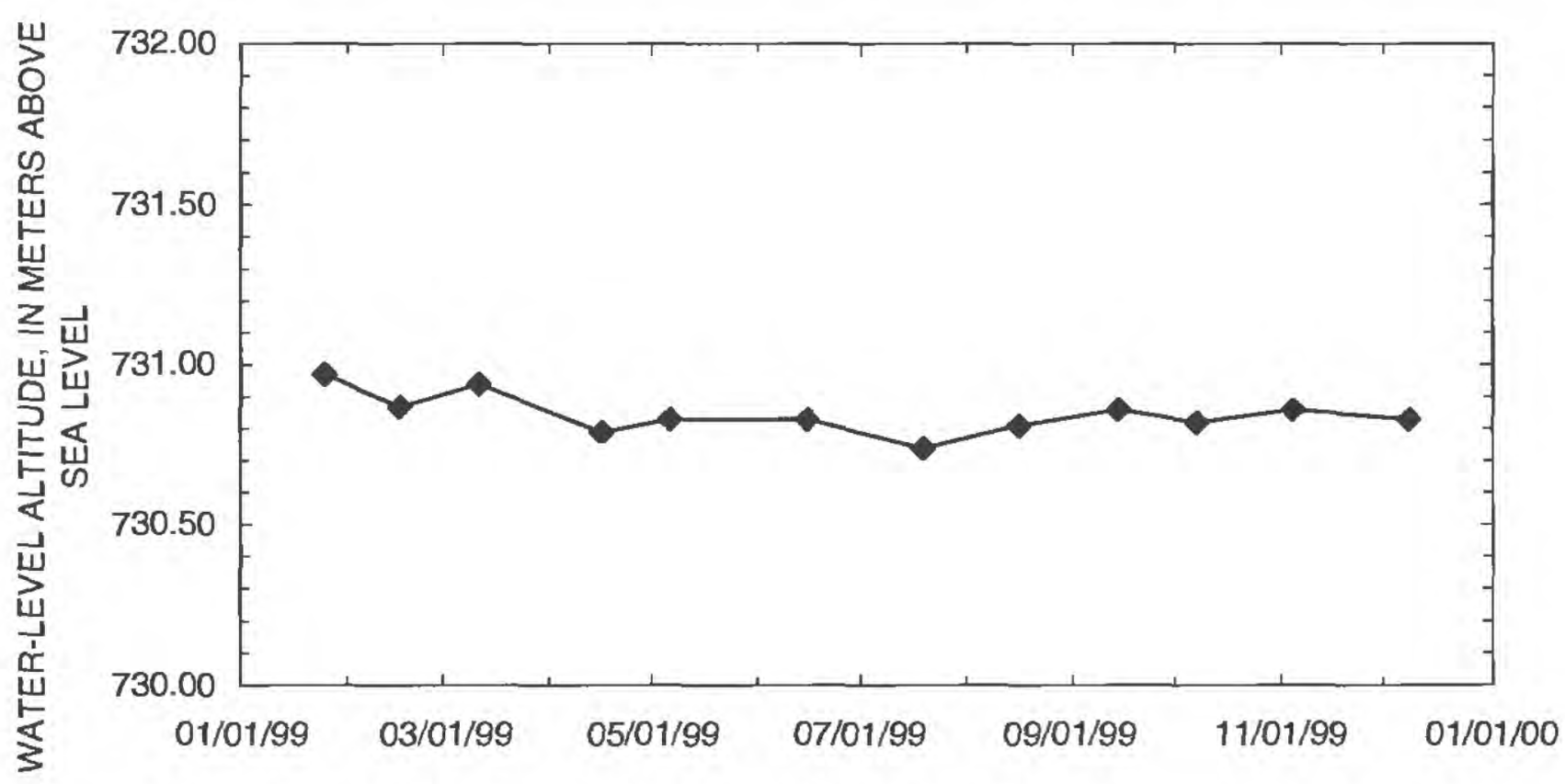

Figure 44. Water-level altitudes for borehole USW H-1, tube 4, during 1999.

Table 23. Measured water-level altitudes, 1999, for borehole USW H-1, tube 4

\begin{tabular}{cccc}
\hline Date & Time & $\begin{array}{c}\text { Water-fevel altitude } \\
\text { (meters above sea } \\
\text { level) }\end{array}$ & $\begin{array}{c}\text { Equipment } \\
\text { used to } \\
\text { measure water } \\
\text { level }\end{array}$ \\
\hline $01 / 25 / 99$ & 1110 & 730.97 & Chain \#3 \\
$02 / 16 / 99$ & 1216 & 730.87 & Chain \#3 \\
$03 / 11 / 99$ & 1153 & 730.94 & Chain \#3 \\
$04 / 16 / 99$ & 1205 & 730.79 & Chain \#3 \\
$05 / 06 / 99$ & 1325 & 730.83 & Chain \#3 \\
$06 / 15 / 99$ & 1042 & 730.83 & Chain \#3 \\
$07 / 19 / 99$ & 1130 & 730.74 & Chain \#3 \\
$08 / 16 / 99$ & 1221 & 730.81 & Chain \#3 \\
$09 / 14 / 99$ & 1034 & 730.86 & Chain \#3 \\
$10 / 07 / 99$ & 1111 & 730.82 & Chain \#3 \\
$11 / 04 / 99$ & 1207 & 730.86 & Chain \#3 \\
$12 / 08 / 99$ & 1307 & 730.83 & Chain \#3 \\
\hline
\end{tabular}

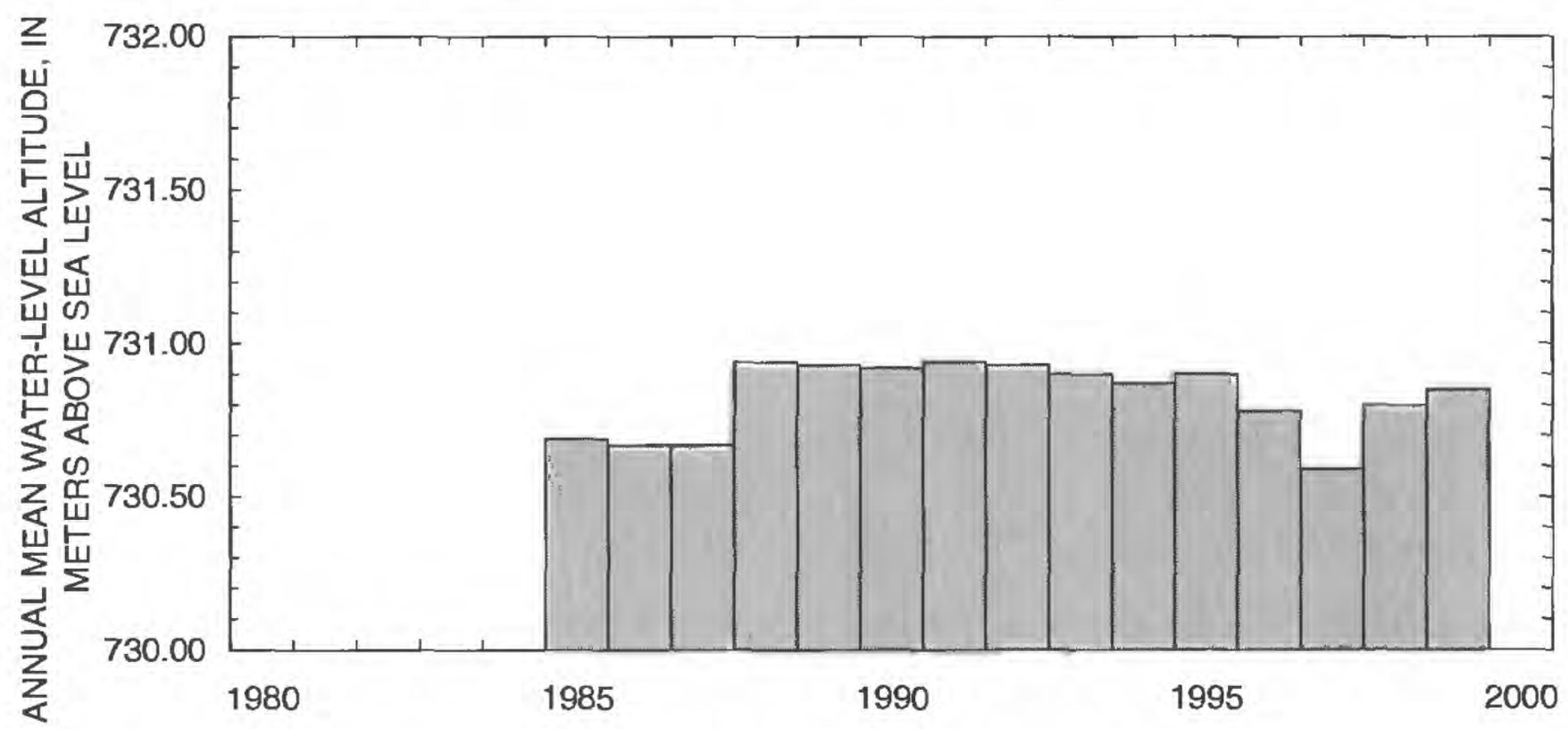

Figure 45. Annual mean water-level altitudes for borehole USW H-1, tube 4. 


\section{Borehole USW H-3}

\section{Borehole specifications}

1. Location and identification:

Nevada State Plane North American Datum of 1927 Central Zone Coordinates (meters): N 230,594; E 170,216 (U.S. Department of Energy, written commun., 1999, MO9907YMP99025.001)

Latitude and longitude: $36^{\circ} 49^{\prime} 42^{\prime \prime} \mathrm{N}$.; $116^{\circ} 28^{\prime} 01^{\prime \prime W}$. (Converted from Nevada State Plane North American Datum of 1927 Central Zone Coordinates)

U.S. Geological Survey Site ID: 364942116280001 (entire borehole), 364942116280004 (upper interval), and 364942116280005 (lower interval).

2. Drilling and casing information:

Borehole started: January 27, 1982 (Fenix \& Scisson, Inc., 1987a. p. 21).

Borehole completed: March 19, 1982 (Fenix \& Scisson, Inc., 1987a, p. 21).

Drilling method: Rotary, using rock bits and air, soap circulating medium (Robison and others. 1988, p. 104).

Bit diameter, below land surface: 0 to $8.84 \mathrm{~m}$, $914.40 \mathrm{~mm} ; 8.84$ to $39.62 \mathrm{~m}, 660.4 \mathrm{~mm} ; 39.62$ to $807.72 \mathrm{~m}, 374.65 \mathrm{~mm} ; 807.72$ to $1,219.20$ m, 222.25 mm (Fenix \& Scisson, Inc., 1987a, p. 21).

Casing, below land surface: 0 to $8.84 \mathrm{~m}$, 762.00 -mm-inside-diameter; 0 to $38.40 \mathrm{~m}$, 381.25-mm-inside-diameter; 0 to $792.48 \mathrm{~m}$, 252.73 mm (Fenix \& Scisson, Inc., 1987a, p. 21).

Total drilled depth: 1,219.20 m (Fenix \& Scisson, Inc., 1987a, p. 21).

3. Description of access tube and depth intervals for measuring water levels:

Inflatable packer installed February 1983, center of packer at a depth of $1,190.40 \mathrm{~m}$ below land surface. The packer was removed November 1983 so hydraulic testing could be conducted. During May 1984 a straddle packer was installed with a 4.27-m spacing between center of packers. Location of top and bottom of packers is not clear; however, packers set to test a zone from $1,117.09 \mathrm{~m}$ to $1,121.36 \mathrm{~m}$ below land surface (Fenix \& Scisson, Inc., 1987a, p. 28, 29, 35, and 36). In December 1990, the straddle packer was removed for maintenance. Inspection of the packer revealed that the tube through the straddle packer had been plugged since the 1984 installation (Tucci, O’Brien, and Burkhardt, 1996, p. 86). Following maintenance, the straddle packer was replaced in the borehole on December 14, 1990, with the bottom of the straddle packer at $1,061 \mathrm{~m}$ below land surface (Tucci, O'Brien, and Burkhardt, 1996, p. 83).

Upper interval: 41-mm-inside-diameter openended tubing, extending from land surface to depth of about $762 \mathrm{~m}$. Tube monitors upper interval of borehole USW H-3, from the water table to top of inflatable packer. Interval monitored is within bedded tuff and the Tram Tuff of the Crater Flat Group (Robison and others, 1988 , p. 104). Stratigraphic nomenclature presented by Robison revised to agree with stratigraphic nomenclature in Sawyer and others (1994, p. 1305).

Lower interval: 62-mm-inside-diameter tubing that has an inflatable packer on bottom end extending from land surface to $1,061 \mathrm{~m}$. Tube monitors lower interval of borehole USW H-3, from the bottom of the packer to the bottom of borehole. Interval monitored is within the Tram Member of the Crater Flat Tuff and the Lithic Ridge Tuff (Tucci, O'Brien, and Burkhardt, 1996, p. 83).

4. Information for calculating water-level altitude:

Reference point: Top of metal tag on well casing; altitude $1,483.47 \mathrm{~m}$ (surveyed by U.S. Geological Survey in 1984; Merle E. Southern, National Mapping Division, U.S. Geological Survey, written commun., 1985).

Measurement point: Top of access tubes, $0.174 \mathrm{~m}$, upper interval; $0.201 \mathrm{~m}$, lower interval. Each measuring point above reference point.

Depth correction for borehole deviation from vertical: Computed from borehole deviation survey dated February $3,1982,-0.079 \mathrm{~m}$, upper interval, based on approximate depth to water of $752 \mathrm{~m}$ (1992 data); $-0.079 \mathrm{~m}$, lower interval, based on approximate depth to water of $751 \mathrm{~m}$ (1998 data) or interpolated directly from borehole deviation survey for the October through December 1999 measurements. 
Borehole USW H-3. upper interval was measured periodically during 1999 with Chain \#3. Water levels fluctuated within a $0.23-\mathrm{m}$ range during 1999 (fig. 46) with the lowest water level being $731.73 \mathrm{~m}$ above sea level (11-03-99) and the highest water level being $731.96 \mathrm{~m}$ above sea level (03-0899) (table 24). The mean water-level altitude of the 1999 data was $731.89 \mathrm{~m}$ above sea level and was within the range of previous annual mean water-level altitudes from 1985 to 1998 (fig. 47). Comparisons with previous water levels may not be accurate due to possible packer failure (Graves, 2000).

Borehole USW H-3, lower interval was measured periodically during 1999 with Chain \#3 and the 2,800-foot reference tape. Water levels fluctuated within a $0.75-\mathrm{m}$ range during 1999 (fig. 48) with the lowest water level being $731.91 \mathrm{~m}$ above sea level (11-03-99) and the highest water level being $732.66 \mathrm{~m}$ above sea level (01-07-99) (table 25). Water levels generally declined throughout the year following the downward trend Graves (2000, p. 59) discussed as the results of possible packer failure. The mean water-level altitude of the 1999 data was $732.19 \mathrm{~m}$ above sea level and was less than the range of previous annual mean water-level altitudes from 1990 to 1996 (fig. 49). Comparisons with previous water levels may not be accurate due to possible packer failure.

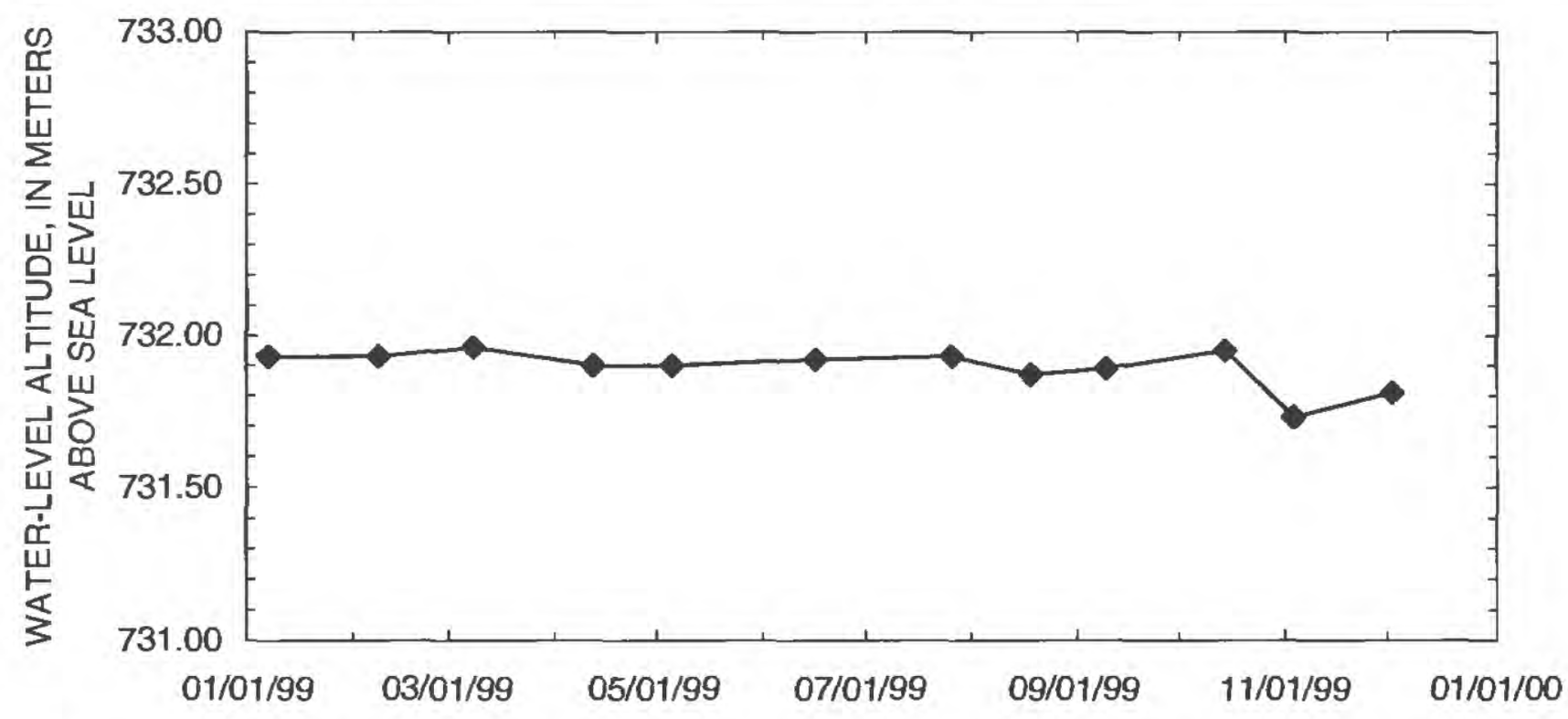

Figure 46. Water-level altitudes for borehole USW H-3, upper interval, during 1999.

Table 24. Measured water-level altitudes, 1999, for borehole USW H-3, upper interval

\begin{tabular}{cccc}
\hline Date & Time & $\begin{array}{c}\text { Water-level altitude } \\
\text { (meters above sea } \\
\text { level) }\end{array}$ & $\begin{array}{c}\text { Equipment } \\
\text { used to } \\
\text { measure water } \\
\text { level }\end{array}$ \\
\hline $01 / 07 / 99$ & 1307 & 731.93 & Chain \#3 \\
$02 / 08 / 99$ & 1457 & 731.93 & Chain \#3 \\
$03 / 08 / 99$ & 1505 & 731.96 & Chain \#3 \\
$04 / 12 / 99$ & 1220 & 731.90 & Chain \#3 \\
$05 / 05 / 99$ & 1144 & 731.90 & Chain \#3 \\
$06 / 16 / 99$ & 950 & 731.92 & Chain \#3 \\
$07 / 26 / 99$ & 1159 & 731.93 & Chain \#3 \\
$08 / 18 / 99$ & 1227 & 731.87 & Chain \#3 \\
$09 / 09 / 99$ & 1217 & 731.89 & Chain \#3 \\
$10 / 14 / 99$ & 1415 & 731.95 & Chain \#3 \\
$11 / 03 / 99$ & 1307 & 731.73 & Chain \#3 \\
$12 / 02 / 99$ & 1335 & 731.81 & Chain \#3 \\
\hline
\end{tabular}




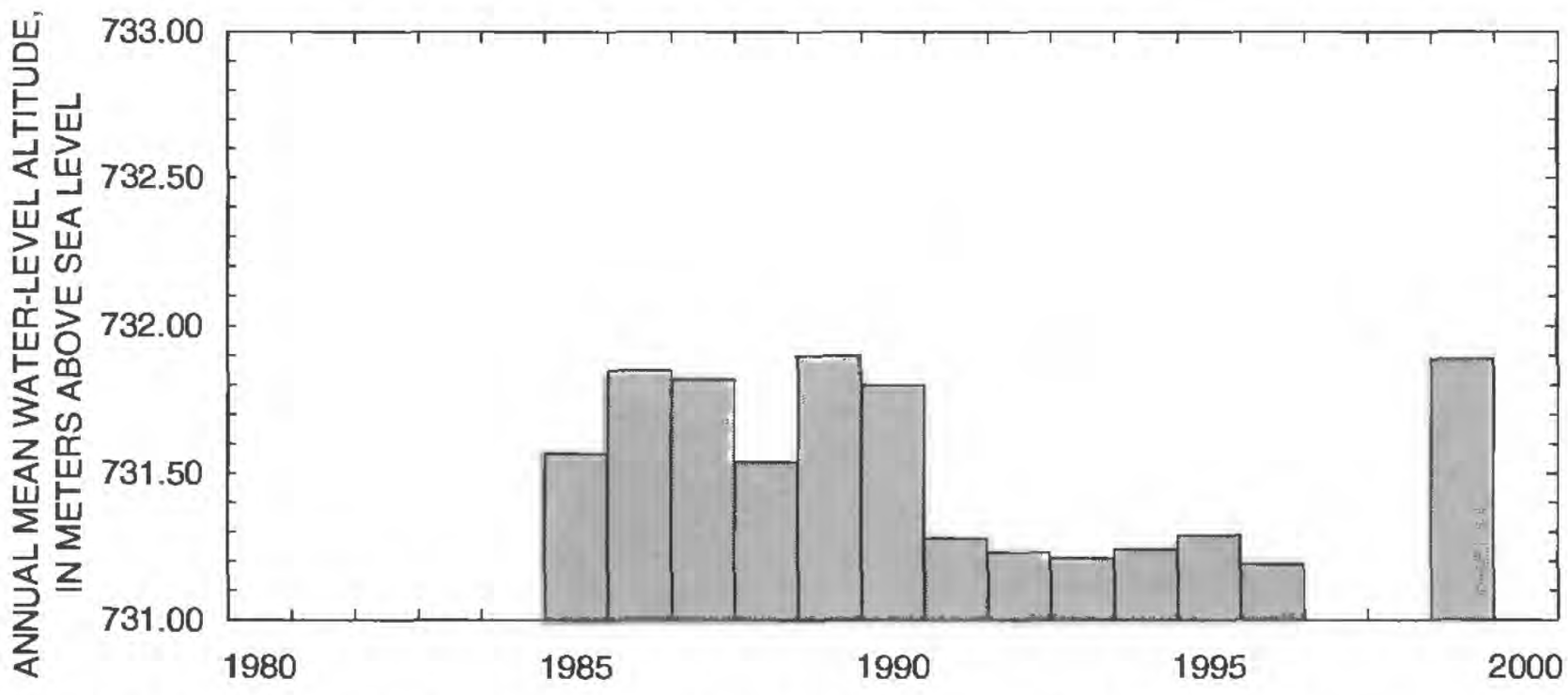

Figure 47. Annual mean water-level altitudes for borehole USW H-3, upper interval.

Table 25. Measured water-level altitudes, 1999, for borehole USW H-3, lower interval

\begin{tabular}{rrrr}
\hline Date & Time & $\begin{array}{c}\text { Water-level altitude } \\
\text { (meters above sea } \\
\text { level) }\end{array}$ & $\begin{array}{r}\text { Equipment used to } \\
\text { measure water level }\end{array}$ \\
\hline $01 / 07 / 99$ & 1351 & 732.66 & Chain \#3 \\
$02 / 08 / 99$ & 1413 & 732.50 & Chain \#3 \\
$03 / 08 / 99$ & 1419 & 732.28 & Chain \#3 \\
$04 / 12 / 99$ & 1140 & 732.19 & Chain \#3 \\
$05 / 05 / 99$ & 1105 & 732.16 & Chain \#3 \\
$06 / 16 / 99$ & 912 & 732.17 & Chain \#3 \\
$07 / 26 / 99$ & 1123 & 732.17 & Chain \#3 \\
$08 / 09 / 99$ & 849 & 732.19 & 2,800 -foot reference tape \\
$08 / 09 / 99$ & 1611 & 732.14 & 2,800 foot-reference tape \\
$09 / 09 / 99$ & 1256 & 732.07 & Chain \#3 \\
$10 / 14 / 99$ & 904 & 732.12 & 2,800 -foot reference tape \\
$10 / 14 / 99$ & 1322 & 732.14 & 2,800 -foot reference tape \\
$11 / 03 / 99$ & 1223 & 731.91 & Chain \#3 \\
$12 / 02 / 99$ & 1258 & 732.01 & Chain \#3 \\
\hline
\end{tabular}

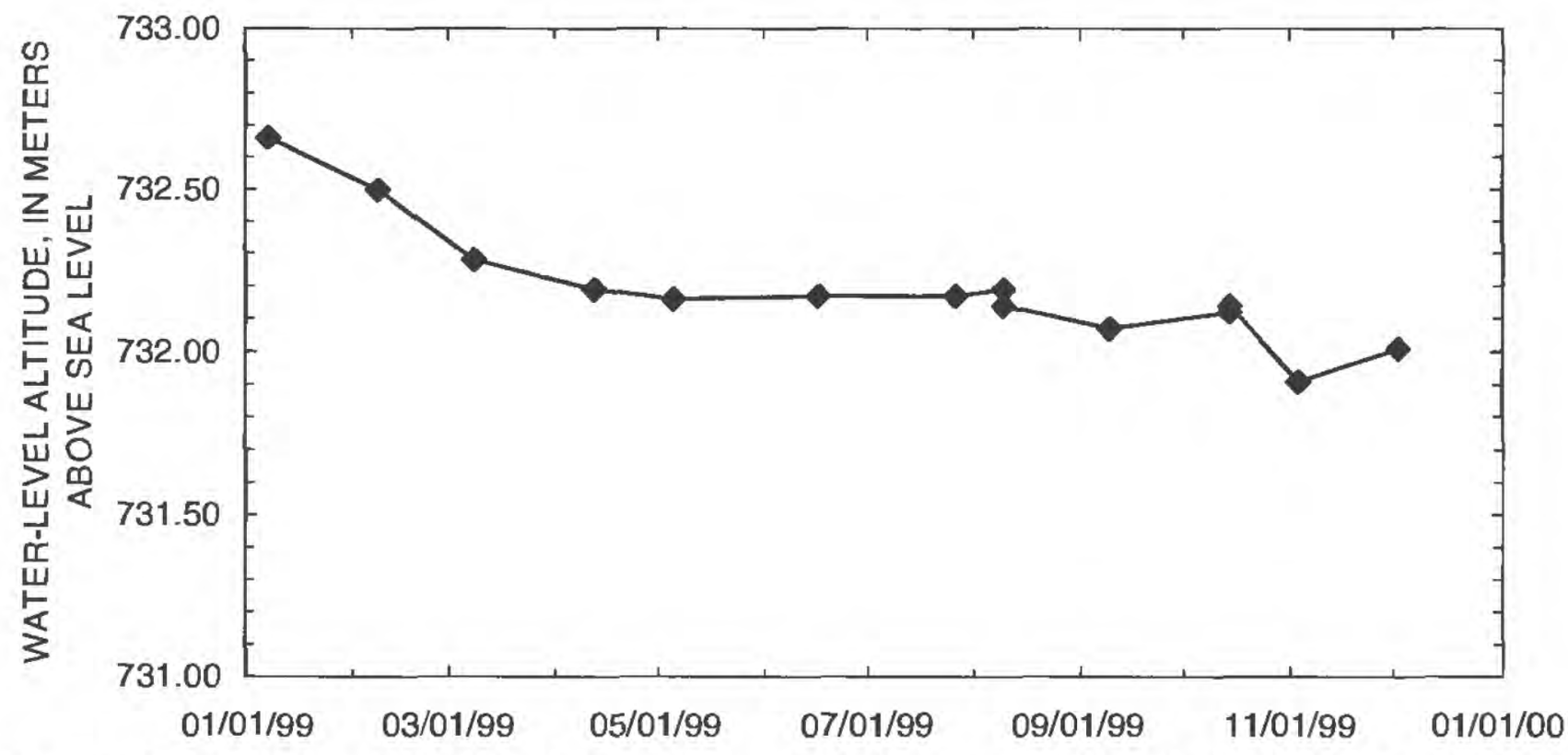

Figure 48. Water-level altitudes for borehole USW H-3, lower interval, during 1999. 


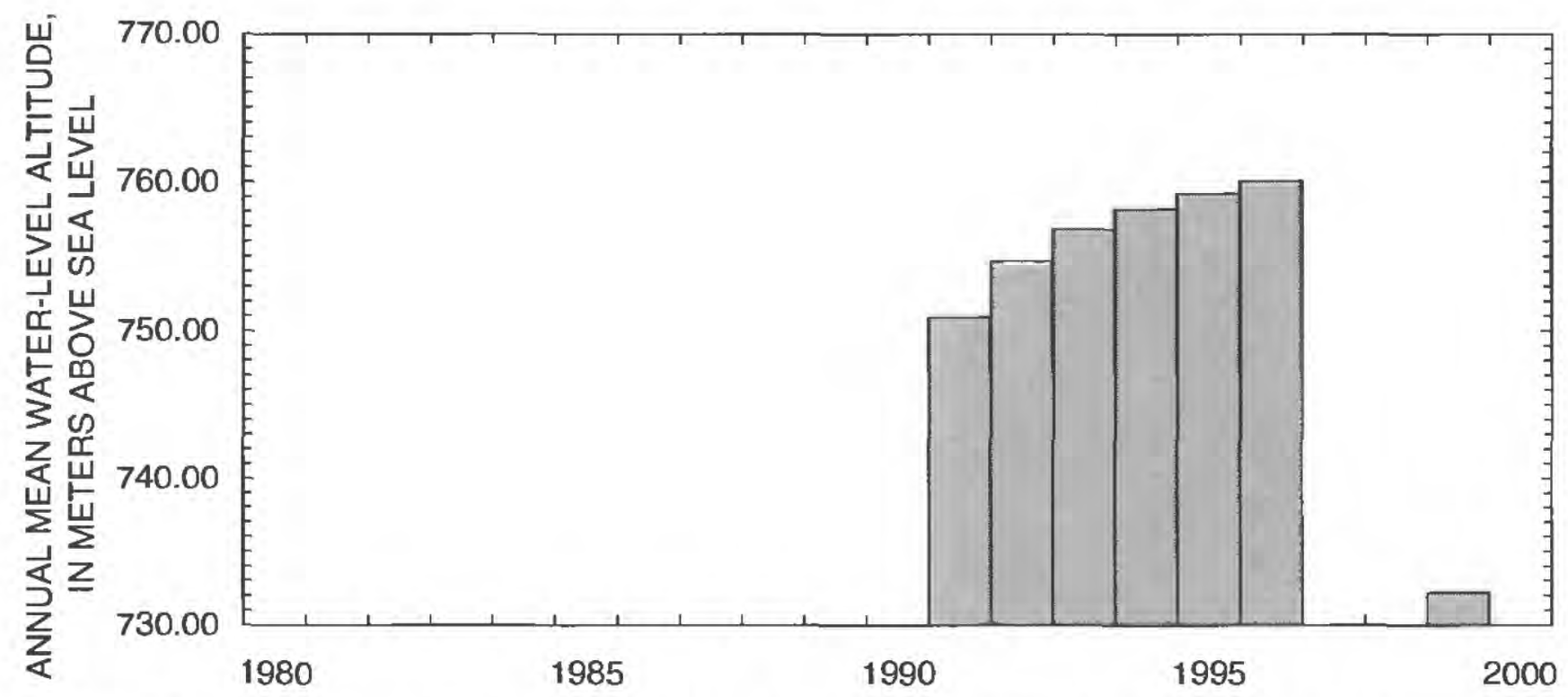

Figure 49. Annual mean water-level altitudes for borehole USW H-3, lower interval.

\section{Borehole USW H-4}

\section{Borehole specifications}

1. Location and identification:

Nevada State Plane North American Datum of 1927 Central Zone Coordinates (meters): N 232,149; E 171,880 (U.S. Department of Energy, written commun., 1999, MO9907YMP99025.001)

Latitude and longitude: $36^{\circ} 50^{\prime} 32^{\prime \prime} \mathrm{N}$.; $116^{\circ} 26^{\prime} 54^{\prime \prime} \mathrm{W}$. (Converted from Nevada State Plane North American Datum of 1927 Central Zone Coordinates)

U.S. Geological Survey Site ID: 365032116265401 (entire borehole), 365032116265402 (upper interval), and 365032116265403 (lower interval).

2. Drilling and casing information:

Borehole started: March 22, 1982 (Fenix \& Scisson, Inc., 1987a, p. 39).

Borehole completed: June 7, 1982 (Fenix \& Scisson, Inc., 1987a, p. 39).

Drilling method: Rotary, using rock bits and airfoam circulating medium: cores obtained from selected intervals (Robison and others, 1988, p. 111).

Bit diameter, below land surface: 0 to $10.67 \mathrm{~m}$, $914.40 \mathrm{~mm} ; 10.67$ to $46.63 \mathrm{~m}, 660.40 \mathrm{~mm}$; 46.63 to $96.32 \mathrm{~m}, 508.00 \mathrm{~mm} ; 96.32$ to $563.88 \mathrm{~m}, 374.65 \mathrm{~mm} ; 563.88$ to $1,219.20 \mathrm{~m}$, 222.25 mm (Fenix \& Scisson, Inc., 1987a, p. 39).

Casing, below land surface: 0 to $10.67 \mathrm{~m}$. 742.95-mm-inside-diameter; 0 to $94.79 \mathrm{~m}$, 381.25 -mm-inside-diameter; 0 to $560.53 \mathrm{~m}$, 252.73-mm-inside-diameter. 381.25-mminside-diameter casing perforated from 533.40 to $539.50 \mathrm{~m}$ at two shots per $0.3048 \mathrm{~m}$ (Fenix \& Scisson, Inc., 1987a, p. 39).

Total drilled depth: 1,219.20 m (Fenix \& Scisson. Inc., 1987a, p. 39).

3. Description of access tube and depth interval for measuring water levels:

Packer placed in borehole. Bottom of packer at $1,181.40 \mathrm{~m}$ below land surface (Fenix \& Scisson, Inc., 1987a, p. 50).

Upper interval: 48-mm-inside-diameter openended tubing (Robison and others, 1988, p. 111), extending from land surface to depth of $525.78 \mathrm{~m}$ (Fenix \& Scisson, Inc., 1987a, p. 39). Tube monitors upper interval of borehole USW $\mathrm{H}-4$, from the water table to the top of the inflatable packer. Interval monitored is within the Prow Pass, Bullfrog, and Tram Tuffs of the Crater Flat Group, bedded tuff, and upper Lithic Ridge Tuff (Robison and others, 1988, p. 111). Stratigraphic nomenclature presented by Robison revised to agree with stratigraphic nomenclature in Sawyer and others (1994, p. 1305).

Lower interval: 62-mm-inside-diameter tubing with inflatable packer on bottom end (Robison and others, 1988, p. 111). Bottom of packer at $1,181.40 \mathrm{~m}$ below land surface, with slotted and bull nose tail pipe extending from bottom of packer to $1,187.50 \mathrm{~m}$ below land surface (Fenix \& Scisson, Inc.. 1987a, p. 50). Tube monitors lower interval of USW $\mathrm{H}-4$, from the bottom of the packer to the bottom of the borehole. Interval monitored is within the Lithic Ridge Tuff (Robison and others, 1988, 
p. 111). Stratigraphic nomenclature presented by Robison revised to agree with stratigraphic nomenclature in Sawyer and others (1994, p. 1305).

4. Information for calculating water-level altitude:

Reference point: Top of metal tag on well casing; altitude $1,248.74 \mathrm{~m}$ (surveyed by U.S. Geological Survey in 1984; Merle E. Southern, National Mapping Division, U.S. Geological Survey, written commun., 1985).

Measurement point: Top of access tubes, $0.597 \mathrm{~m}$, upper interval; $0.308 \mathrm{~m}$, lower interval. Both measuring points above reference point.

Depth correction for borehole deviation from vertical: Computed from borehole deviation survey dated April 30, 1982 (U.S. Department of Energy, 1982, written commun., NNA.19900820.0123), $-0.064 \mathrm{~m}$, based on approximate depth to water of $518 \mathrm{~m}(1992$ data) or interpolated directly from borehole deviation survey for the October through December 1999 measurements.

Borehole USW H-4, upper interval was measured periodically during 1999 with Chain \#3.
Water levels fluctuated within a $0.18 \mathrm{~m}$ range during 1999 (fig. 50) with the lowest water level being $730.31 \mathrm{~m}$ above sea level (01-28-99) and the highest water level being $730.49 \mathrm{~m}$ above sea level (03-31-99) (table 26). The mean water-level altitude of the 1999 data was $730.40 \mathrm{~m}$ above sea level and was within the range of previous annual mean water-level altitudes from 1985 to 1998 (fig. 51). The annual mean water-level altitudes have been rising since 1997.

Borehole USW H-4, lower interval was measured periodically during 1999 with Chain \#3 and the 2,800-foot reference tape. Water levels fluctuated within a $0.16 \mathrm{~m}$ range during 1999 (fig. 52) with the lowest water level being $730.41 \mathrm{~m}$ above sea level (09-07-99) and the highest water level being $730.57 \mathrm{~m}$ above sea level (08-05-99) (table 27). The mean water-level altitude of the 1999 data was $730.47 \mathrm{~m}$ above sea level and was within the range of previous annual mean water-level altitudes from 1985 to 1998 (fig. 53). The annual mean water-level altitudes have been rising since 1997.

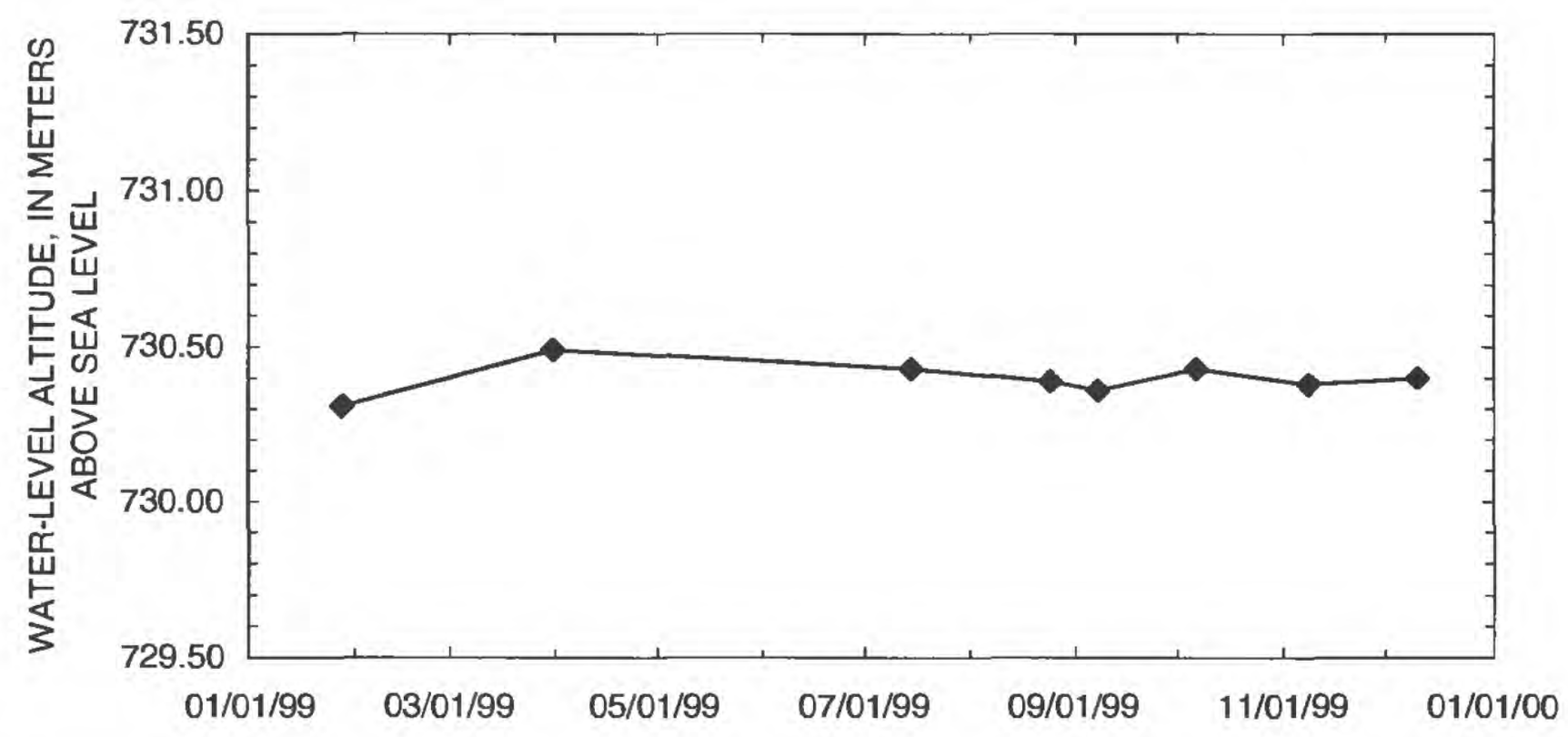

Figure 50. Water-level altitudes for borehole USW H-4, upper interval, during 1999. 
Table 26. Measured water-level altitudes, 1999, for borehole USW H-4, upper interval

\begin{tabular}{cccc}
\hline Date & Time & $\begin{array}{c}\text { Water-level altitude } \\
\text { (meters above sea } \\
\text { level) }\end{array}$ & $\begin{array}{c}\text { Equipment used to } \\
\text { measure water level }\end{array}$ \\
\hline $01 / 28 / 99$ & 1028 & 730.31 & Chain \#3 \\
$03 / 31 / 99$ & 1045 & 730.49 & Chain \#3 \\
$07 / 14 / 99$ & 1456 & 730.43 & Chain \#3 \\
$08 / 24 / 99$ & 1210 & 730.39 & Chain \#3 \\
$09 / 07 / 99$ & 1210 & 730.36 & Chain \#3 \\
$10 / 06 / 99$ & 1011 & 730.43 & Chain \#3 \\
$11 / 08 / 99$ & 1044 & 730.38 & Chain \#3 \\
$12 / 10 / 99$ & 1122 & 730.40 & Chain \#3 \\
\hline
\end{tabular}

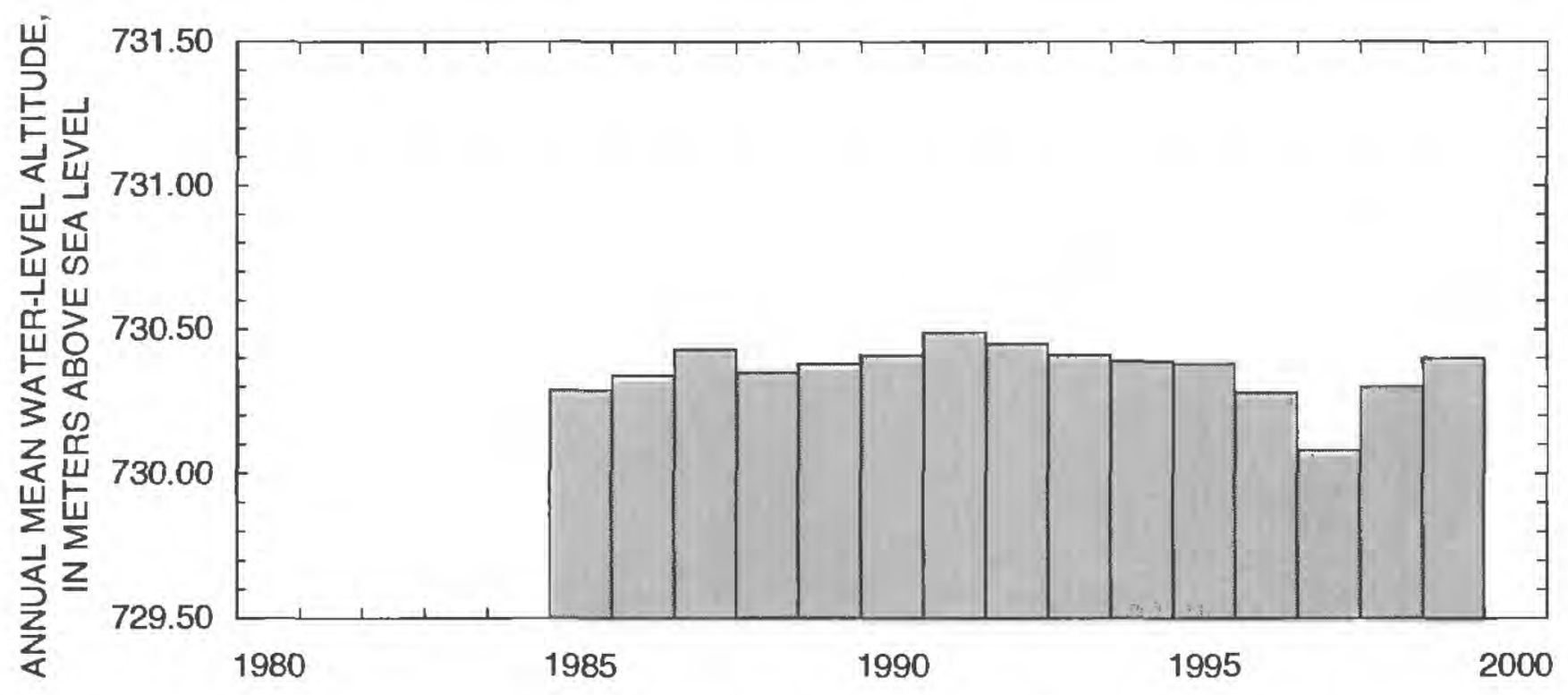

Figure 51. Annual mean water-level altitude for borehole USW H-4, upper interval.

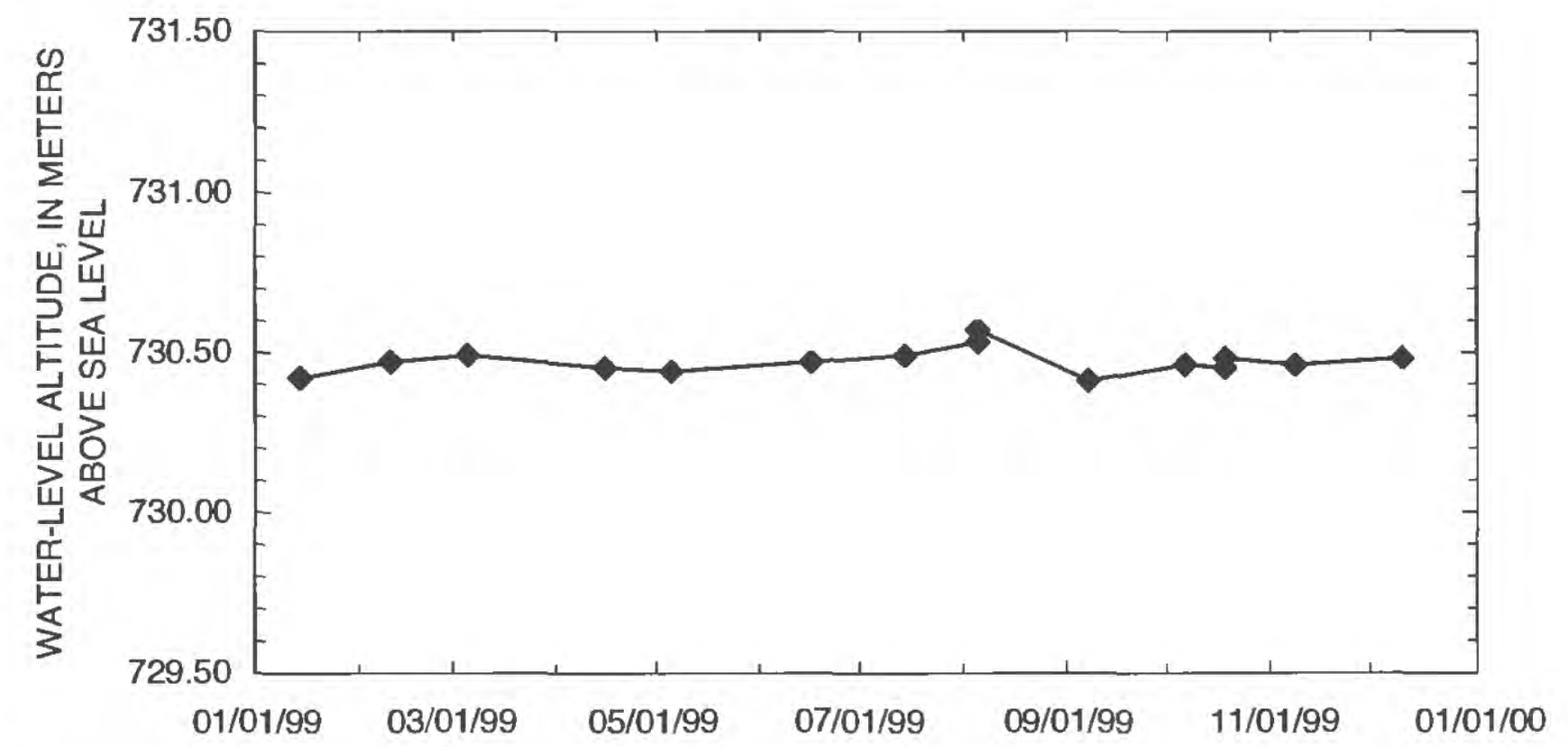

Figure 52. Water-level altitudes for borehole USW H-4, lower interval, during 1999. 
Table 27. Measured water-level altitudes, 1999, for borehole USW H-4, lower interval

\begin{tabular}{crcr}
\hline Date & Time & $\begin{array}{c}\text { Water-level altitude } \\
\text { (meters above sea } \\
\text { level) }\end{array}$ & $\begin{array}{r}\text { Equipment used to } \\
\text { measure water level }\end{array}$ \\
\hline $01 / 14 / 99$ & 919 & 730.42 & Chain \#3 \\
$02 / 10 / 99$ & 1239 & 730.47 & Chain \#3 \\
$03 / 05 / 99$ & 1037 & 730.49 & Chain \#3 \\
$04 / 15 / 99$ & 1525 & 730.45 & Chain \#3 \\
$05 / 05 / 99$ & 1357 & 730.44 & Chain \#3 \\
$06 / 16 / 99$ & 1320 & 730.47 & Chain \#3 \\
$07 / 14 / 99$ & 1523 & 730.49 & Chain \#3 \\
$08 / 05 / 99$ & 900 & 730.53 & 2,800 -foot reference tape \\
$08 / 05 / 99$ & 1418 & 730.57 & 2.800 -foot reference tape \\
$09 / 07 / 99$ & 1118 & 730.41 & Chain \#3 \\
$10 / 06 / 99$ & 944 & 730.46 & Chain \#3 \\
$10 / 18 / 99$ & 954 & 730.45 & 2,800 -foot reference tape \\
$10 / 18 / 99$ & 1225 & 730.48 & 2,800 -foot reference tape \\
$11 / 08 / 99$ & 1008 & 730.46 & Chain \#3 \\
$12 / 10 / 99$ & 1056 & 730.48 & Chain \#3 \\
\hline
\end{tabular}

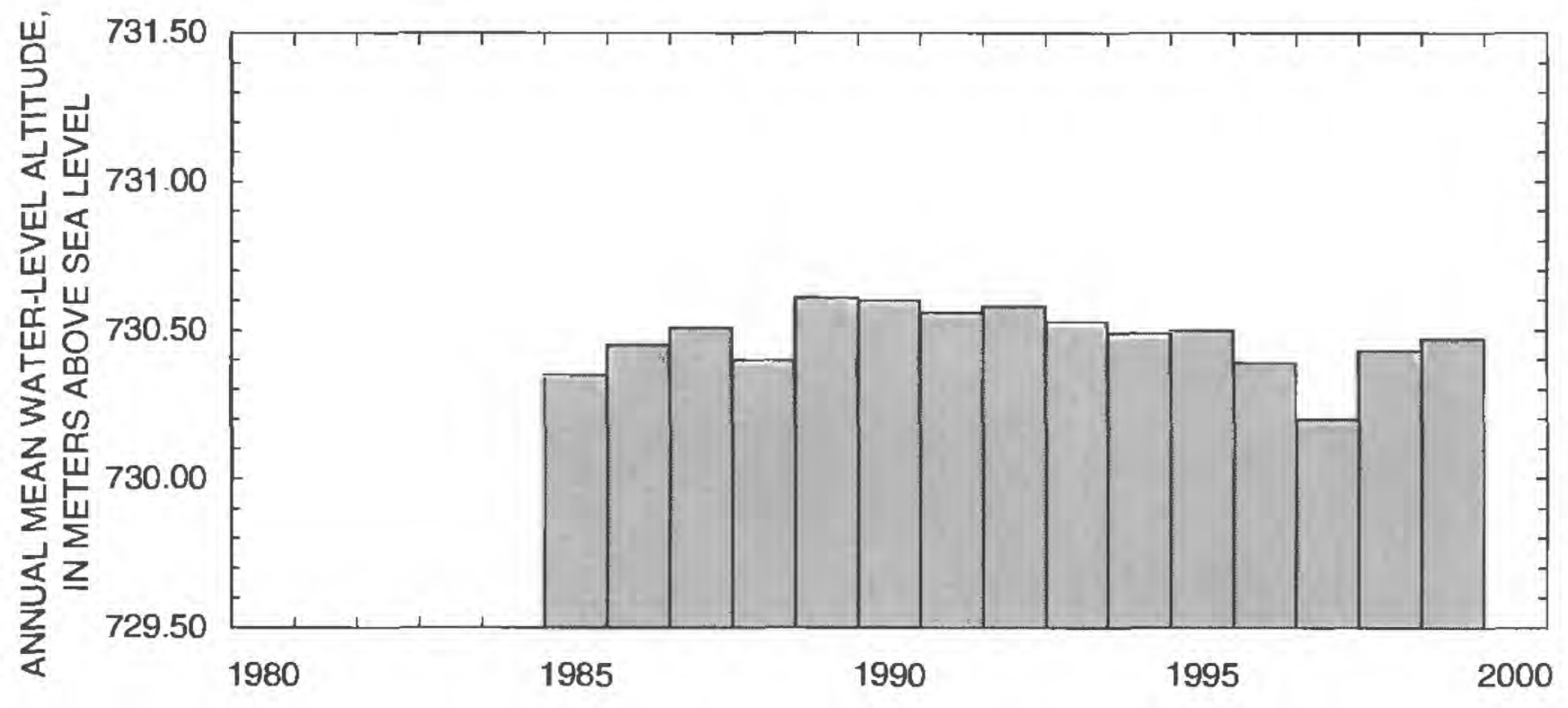

Figure 53. Annual mean water-level altitudes for borehole USW H-4, lower interval. 


\section{Borehole USW H-5}

\section{Borehole specifications}

1. Location and identification:

Nevada State Plane North American Datum of 1927 Central Zone Coordinates (meters): N 233,670; E 170,355 (U.S. Department of Energy, written commun., 1999, MO9907YMP99025.001)

Latitude and longitude: $36^{\circ} 51^{\prime} 22^{\prime \prime} \mathrm{N}$; $116^{\circ} 27^{\prime} 55^{\prime \prime}$. (Converted from Nevada State Plane North American Datum of 1927 Central Zone Coordinates)

U.S. Geological Survey Site ID: 365122116275501 (entire borehole). 365122116275502 (upper interval), and 365122116275503 (lower interval).

2. Drilling and casing information:

Borehole started: May 19, 1982 (Fenix \& Scisson, Inc., 1987a, p. 51).

Borehole completed: August 1, 1982 (Fenix \& Scisson, Inc., 1987a, p. 51).

Drilling method: Rotary, using rock bits and airfoam circulating medium; cores obtained from selected intervals (Robison and others. 1988. p. 116).

Bit diameter, below land surface: 0 to $11.58 \mathrm{~m}$, $914.40 \mathrm{~mm} ; 11.58$ to $94.79 \mathrm{~m}, 508.00 \mathrm{~mm}$; 94.79 to $792.18 \mathrm{~m}, 374.65 \mathrm{~mm} ; 792.18$ to 1,219.20 m, 222.25 mm (Fenix \& Scisson. Inc., 1987a, p. 51).

Casing, below land surface: 0 to $11.58 \mathrm{~m}$, 742.95-mm-inside-diameter; 0 to $94.79 \mathrm{~m}$, 381.00 - $\mathrm{mm}$-inside-diameter; 0 to $787.91 \mathrm{~m}$, 255.27-mm-inside-diameter. 255.27- $\mathrm{mm}$ inside-diameter casing perforated at two holes per $0.3048 \mathrm{~m}$ from 707.14 to $711.71,731.52$ to 736.09 , and 768.10 to $772.67, \mathrm{~m}$ below land surface and with 360 holes from 717.80 to $731.52,736.09$ to 768.10 , and 772.67 to $781.81 \mathrm{~m}$ below land surface, extending below water level: 255 -mm diameter to $788 \mathrm{~m}$, perforated below the water level (Fenix \& Scisson, Inc., 1987a, p. 51).

Total drilled depth: 1,219.20 m (Fenix \& Scisson, Inc., 1987a, p. 51).
3. Description of access tube and depth interval for measuring water levels:

Packer placed in borehole. Bottom of packer at $1,091.18 \mathrm{~m}$ below land surface (Fenix \& Scisson, Inc., 1987a, p. 61)

Upper interval: 48-mm-inside-diameter openended tubing (Robison and others, 1988, p. 116), extending from land surface to a depth of 708.39 m (Fenix \& Scisson, Inc., 1987a, p. 51) 1982 to March 1993, and $708.61 \mathrm{~m}$ (G.M. O’Brien, U.S. Geological Survey, written commun., 1993) March 1993 to present (1999). Tube monitors upper interval of borehole USW H-5, from the water table to the top of the inflatable packer. Interval monitored is within the Bullfrog Tuff of the Crater Flat Group (Robison and others, 1988, p. 116). Stratigraphic nomenclature presented by Robison revised to agree with stratigraphic nomenclature in Sawyer and others (1994, p. 1305).

Lower interval: 62-mm-inside-diameter tubing (Robison and others, 1988, p. 116) that has an inflatable packer on bottom end. Tube extends from land surface to the bottom of the packer. Bottom of the packer at $1,091.18 \mathrm{~m}$ below land surface with $3.96 \mathrm{~m}$ slotted tubing with bull nose tail pipe attached to bottom of packer (Fenix \& Scisson, Inc., 1987a, p. 51) 1982 to March 1993. Packer removed and replaced March 1993 (G.M. O’Brien, U.S. Geological Survey, written commun., 1993). Bottom of packer March 1993 to present (1998) is $843.09 \mathrm{~m}$, with a $3.66 \mathrm{~m}$ slotted pipe attached to the bottom of the packer. Tube monitors the lower interval of borehole USW $\mathrm{H}-5$, from the bottom of the packer to the bottom of the borehole. Interval monitored is within the Bullfrog and Tram Tuffs of the Crater Flat Group and an unnamed tuff between the Bullfrog and Tram Tuffs (Robison and others, 1988, p. 116). Stratigraphic nomenclature presented by Robison revised to agree with stratigraphic nomenclature in Sawyer and others (1994, p. 1305).

4. Information for calculating water-level altitude:

Reference point: Top of metal tag on well casing; altitude 1,478.94 $\mathrm{m}$ (surveyed by U.S. Geological Survey in 1984; Merle E. Southern, 
National Mapping Division, U.S. Geological Survey, written commun., 1985).

Measurement point: Top of access tubes, $0.329 \mathrm{~m}$, upper interval; $0.235 \mathrm{~m}$, lower interval. Both measurement points above the reference point.

Depth correction for borehole deviation from vertical: Computed from borehole deviation survey dated June $23,1982,-0.079 \mathrm{~m}$, based on approximate depth to water of $703 \mathrm{~m} \mathrm{(1992}$ data) or interpolated directly from borehole deviation survey for the October through December 1999 measurements.

Borehole USW H-5, upper interval was measured periodically during 1999 with Chain \#3. Water levels fluctuated within a $0.11 \mathrm{~m}$ range during 1999 (fig. 54) with the lowest water level being 775.46 $m$ above sea level (08-18-99) and the highest water level being $775.57 \mathrm{~m}$ above sea level (03-15-99) (table 28). The mean water-level altitude of the 1999 data was $775.50 \mathrm{~m}$ above sea level and was within the range of previous annual mean water-level altitudes from 1985 to 1998 (fig. 55). The annual mean waterlevel altitude has been rising since 1998 .

Borehole USW H-5, lower interval was measured periodically during 1999 with Chain \#3 and the 2,800-foot reference tape. Water levels fluctuated within a $0.12-\mathrm{m}$ range during 1999 (fig. 56) with the lowest water level being $775.81 \mathrm{~m}$ above sea level (05-05-99 and 11-01-99) and the highest water level being $775.93 \mathrm{~m}$ above sea level (03-15-99) (table 29). The mean water-level altitude of the 1999 data was $775.85 \mathrm{~m}$ above sea level and was greater than the range of previous annual mean water-level altitudes from 1985 to 1998 (fig. 57). The annual mean waterlevel altitude has been rising since 1996.

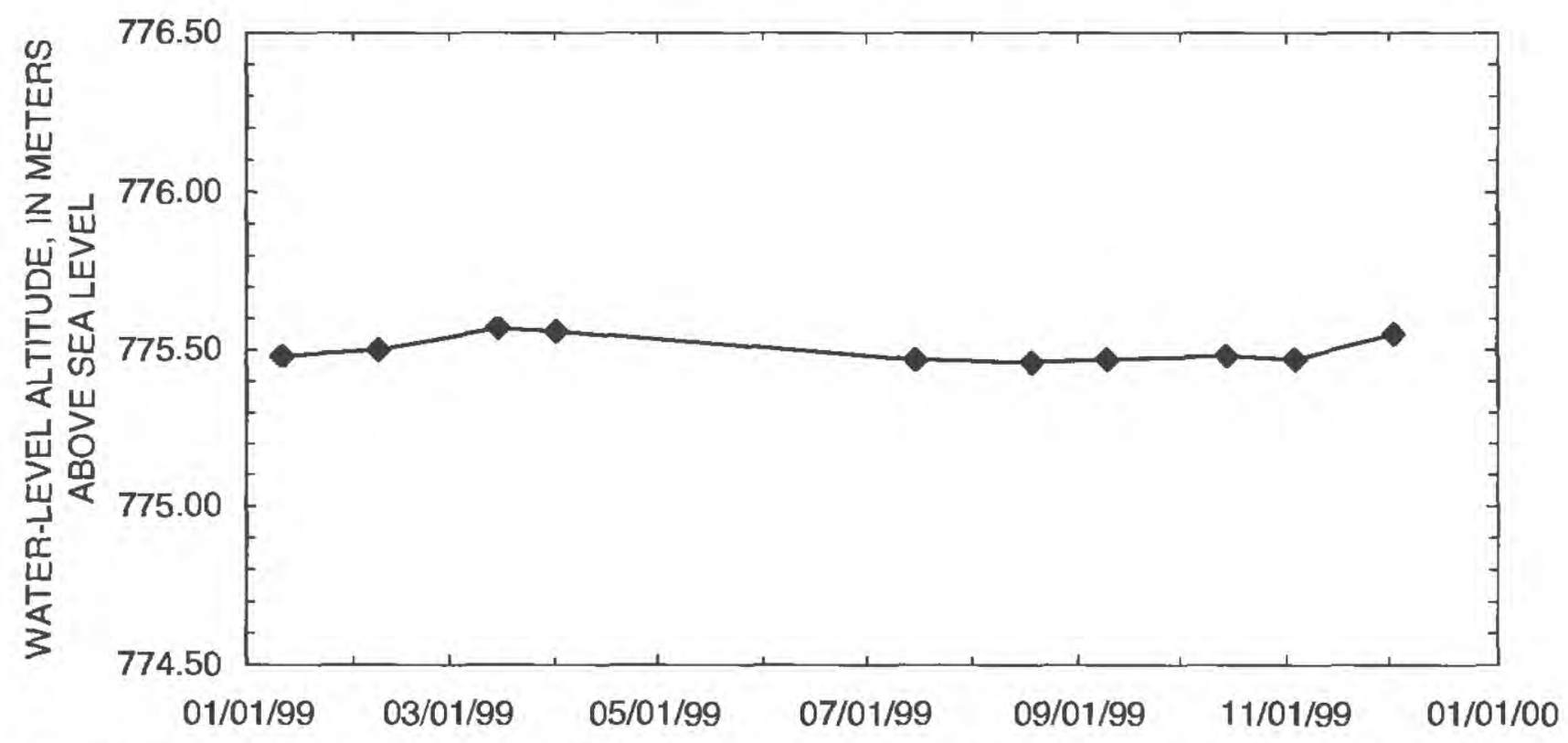

Figure 54. Water-level altitudes for borehole USW H-5, upper interval, during 1999.

Table 28. Measured water-level altitudes, 1999, for borehole USW $\mathrm{H}-5$, upper interval

\begin{tabular}{cccc}
\hline Date & Time & $\begin{array}{c}\text { Water-level altitude } \\
\text { (meters above sea } \\
\text { level) }\end{array}$ & $\begin{array}{c}\text { Equipment used } \\
\text { to measure water } \\
\text { level }\end{array}$ \\
\hline $01 / 11 / 99$ & 1110 & 775.48 & Chain \#3 \\
$02 / 08 / 99$ & 1230 & 775.50 & Chain \#3 \\
$03 / 15 / 99$ & 1027 & 775.57 & Chain \#3 \\
$04 / 01 / 99$ & 1058 & 775.56 & Chain \#3 \\
$07 / 15 / 99$ & 1508 & 775.47 & Chain \#3 \\
$08 / 18 / 99$ & 1109 & 775.46 & Chain \#3 \\
$09 / 09 / 99$ & 1024 & 775.47 & Chain \#3 \\
$10 / 14 / 99$ & 1006 & 775.48 & Chain \#3 \\
$11 / 03 / 99$ & 1000 & 775.47 & Chain \#3 \\
$12 / 02 / 99$ & $12: 04$ & 775.55 & Chain \#3 \\
\hline
\end{tabular}




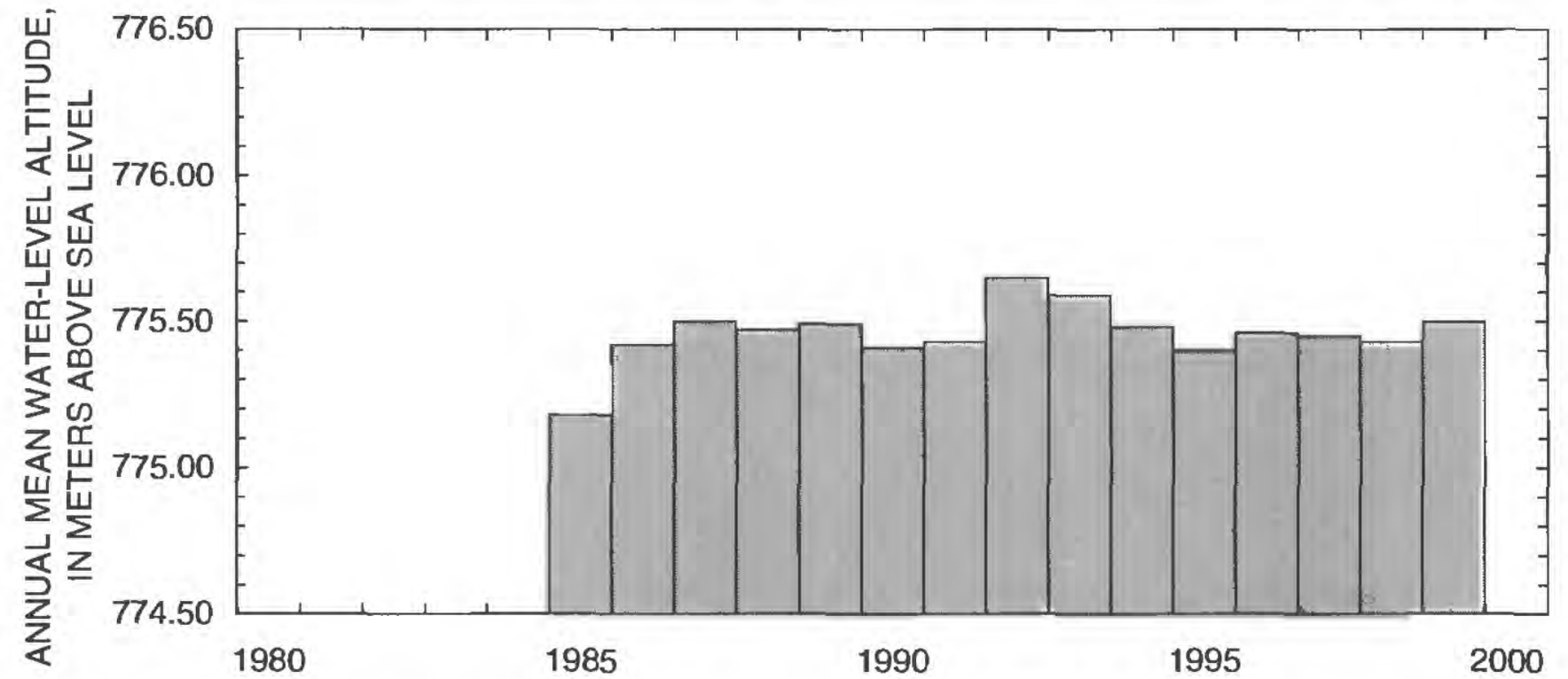

Figure 55. Annual mean water-level altitudes for borehole USW $\mathrm{H}-5$, upper interval.

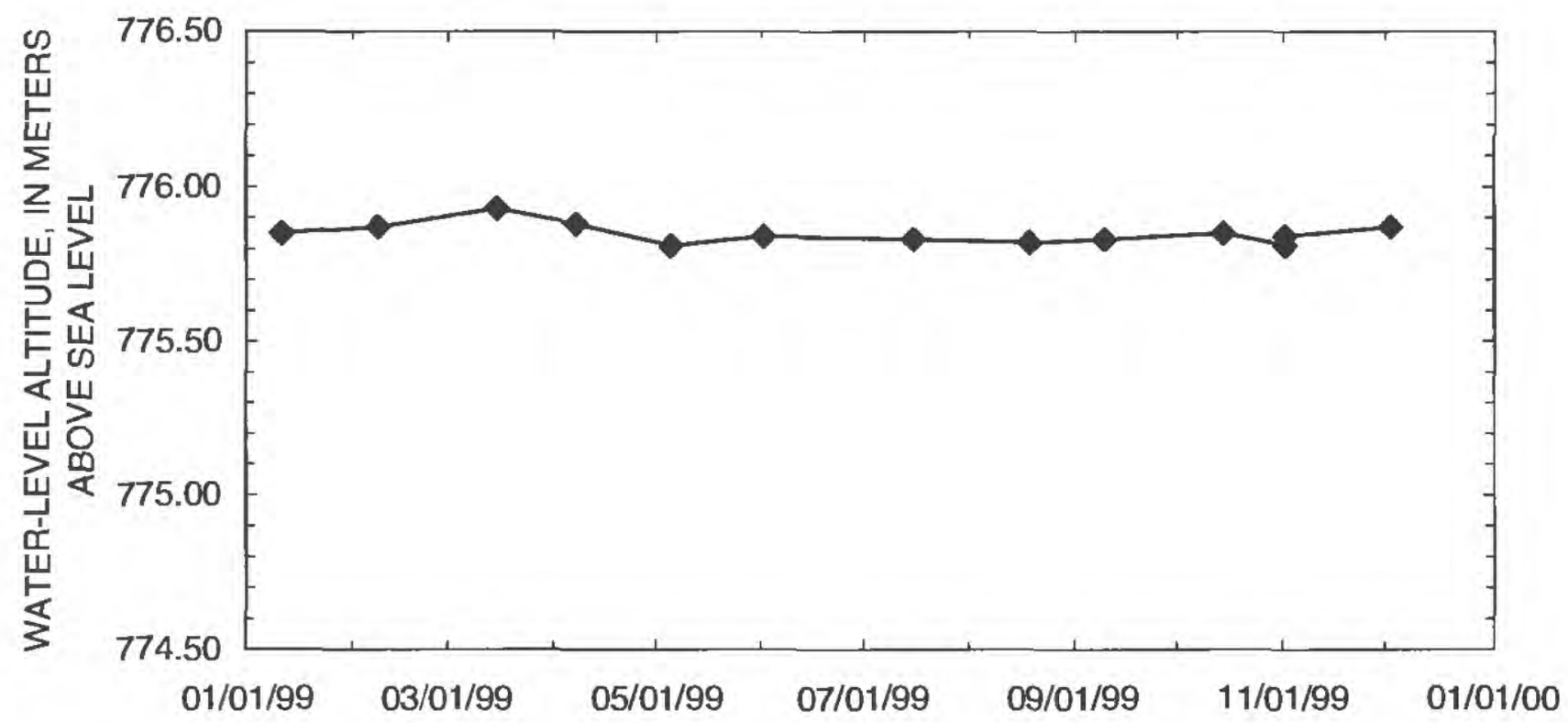

Figure 56. Water-level altitudes for borehole USW H-5, lower interval, during 1999.

Table 29. Measured water-level altitudes, 1999, for borehole USW H-5, lower interval

\begin{tabular}{crrr}
\hline Date & Time & $\begin{array}{c}\text { Water-level altitude } \\
\text { (meters above sea } \\
\text { level) }\end{array}$ & $\begin{array}{c}\text { Equipment used to measure } \\
\text { water level }\end{array}$ \\
\hline $01 / 11 / 99$ & 1028 & 775.85 & Chain \#3 \\
$02 / 08 / 99$ & 1149 & 775.87 & Chain \#3 \\
$03 / 15 / 99$ & 950 & 775.93 & Chain \#3 \\
$04 / 07 / 99$ & 1045 & 775.88 & Chain \#3 \\
$05 / 05 / 99$ & 917 & 775.81 & Chain \#3 \\
$06 / 01 / 99$ & 1144 & 775.84 & Chain \#3 \\
$07 / 15 / 99$ & 1048 & 775.83 & Chain \#3 \\
$08 / 18 / 99$ & 954 & 775.82 & Chain \#3 \\
$09 / 09 / 99$ & 1101 & 775.83 & Chain \#3 \\
$10 / 14 / 99$ & 1039 & 775.85 & Chain \#3 \\
$11 / 01 / 99$ & 952 & 775.81 & 2,800 -foot reference tape \\
$11 / 01 / 99$ & 1308 & 775.84 & 2,800 -foot reference tape \\
$12 / 02 / 99$ & 1130 & 775.87 & Chain \#3 \\
\hline
\end{tabular}




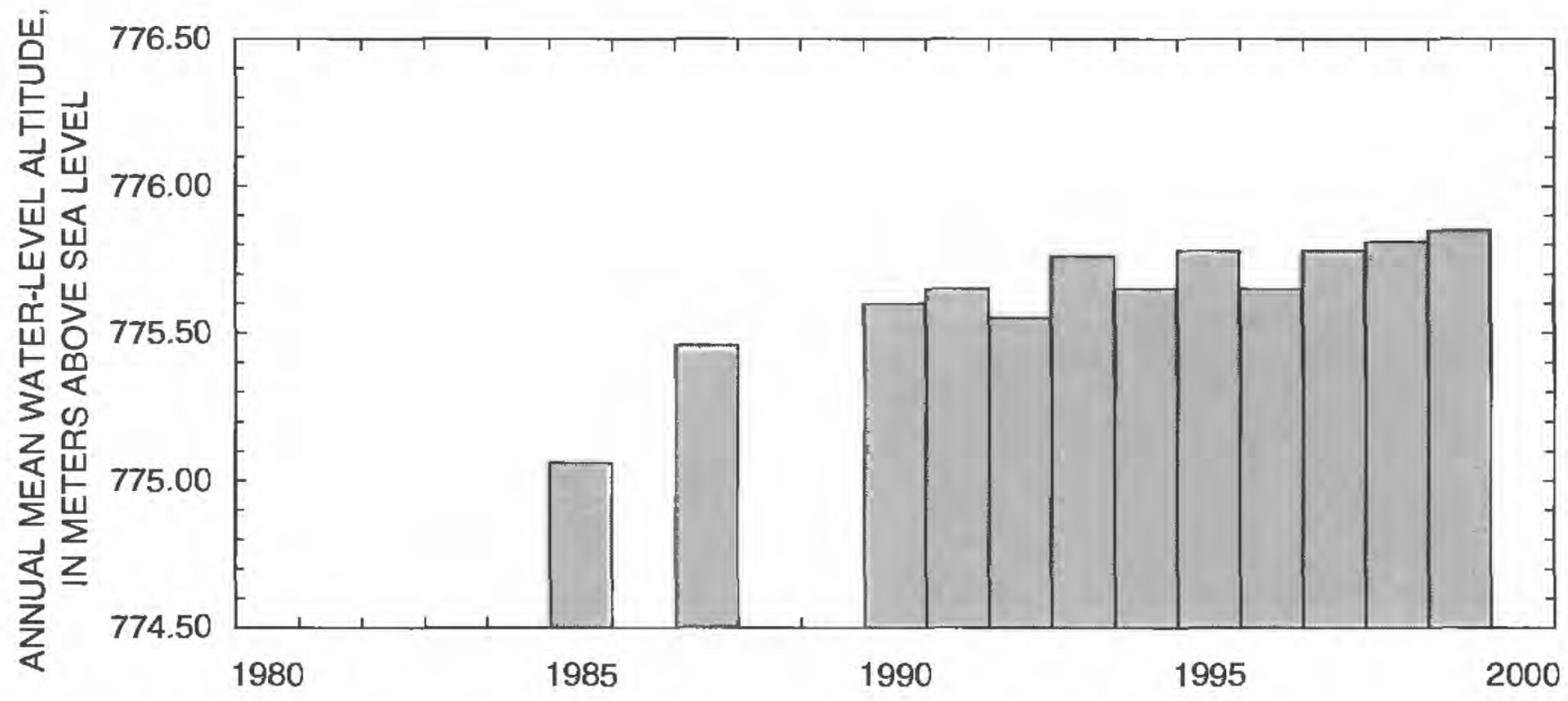

Figure 57. Annual mean water-level altitudes for borehole USW $\mathrm{H}-5$, lower interval.

\section{Borehole USW H-6}

\section{Borehole specifications}

\section{Location and identification:}

Nevada State Plane North American Datum of 1927 Central Zone Coordinates (meters): N 232,654; E 168,882 (U.S. Department of Energy, written commun., 1999, MO9907YMP99025.001)

Latitude and longitude: $36^{\circ} 50^{\prime} 49^{\prime \prime} \mathrm{N}$.; $116^{\circ} 28^{\prime} 55^{\prime \prime} \mathrm{W}$. (Converted from Nevada State Plane North American Datum of 1927 Central Zone Coordinates)

U.S. Geological Survey Site ID: 365049116285501 (entire borehole), 365049116285504 (upper interval), and 365049116285505 (lower interval).

2. Drilling and casing information:

Borehole started: August 7, 1982 (Fenix \& Scisson, Inc., 1987a, p. 63).

Borehole completed: October 28, 1982 (Fenix \& Scisson, Inc., 1987a, p. 63).

Drilling method: Rotary, using rock bits and airfoam circulating medium; cores obtained from selected intervals (Robison and others, 1988, p. 121).

Bit diameter, below land surface: 0 to $10.05 \mathrm{~m}$, $914.4 \mathrm{~mm} ; 10.05$ to $102.11 \mathrm{~m}, 558.8 \mathrm{~mm}$; 102.11 to $582.78 \mathrm{~m}, 374.65 \mathrm{~mm} ; 582.78$ to $1,216.15 \mathrm{~m}, 222.25 \mathrm{~mm} ; 1,216.15$ to $1,219.81$ m, 155.58 mm (Fenix \& Scisson, Inc., 1987a, p. 63).
Casing, below land surface: 0 to $9.45 \mathrm{~m}$, 746.15-mm-inside-diameter; 0 to $94.79 \mathrm{~m}$, 381.25-mm-inside-diameter; 0 to $580.95 \mathrm{~m}$, 250.19-mm-inside-diameter (Fenix \& Scisson. Inc., 1987a, p. 63).

Total drilled depth: 1,219.81 m (Fenix \& Scisson, Inc., 1987a, p. 63).

3. Description of access tube and depth interval for measuring water levels:

Packer placed in borehole. Bottom of packer at $752.25 \mathrm{~m}$ below land surface (Fenix \& Scisson, Inc., 1987a, p. 79)

Upper interval: 48-mm-inside-diameter openended tubing (Robison and others, 1988. p. 121), extending from land surface to 533.86 m (Fenix \& Scisson, Inc., 1987a, p. 63). Tube monitors upper interval of borehole USW H-6, from the water table to the top of the inflatable packer. Interval monitored is within the Prow Pass, Bullfrog, and Tram Tuffs of the Crater Flat Group, and bedded tuff (Robison and others, 1988, p. 121). Stratigraphic nomenclature presented by Robison revised to agree with stratigraphic nomenclature in Sawyer and others (1994, p. 1305).

Lower interval: 62-mm-inside-diameter tubing (Robison and others, 1988, p. 121) with inflatable packer on bottom end. Tubing extends from land surface to bottom of packer and is open at the bottom of the packer. Bottom of packer is set at $752.25 \mathrm{~m}$ below land surface. Tube monitors lower interval from the bottom of the packer to the bottom of the borehole. 
Interval monitored is within the Tram Tuff of the Crater Flat Group, bedded tuff, an unnamed lava between the Tram Tuff and Lithic Ridge Tuff (Carr, 1988, p. 37; Sawyer and others, 1994, p. 1305), and the Lithic Ridge Tuff (Robison and others, 1988, p. 121). Stratigraphic nomenclature presented by Robison revised to agree with stratigraphic nomenclature in Sawyer and others (1994, p. 1305).

4. Information for calculating water-level altitude:

Reference point: Top of metal tag on well casing; altitude $1,302.06 \mathrm{~m}$ (surveyed by U.S. Geological Survey in 1984; Merle E. Southern, National Mapping Division, U.S. Geological Survey, written commun., 1985).

Measurement point: Top of access tubes, $0.207 \mathrm{~m}$ above reference point, upper interval; $0.235 \mathrm{~m}$ above reference point, lower interval.

Depth correction for borehole deviation from vertical: Computed from borehole deviation survey dated October $8,1982,-0.052 \mathrm{~m}$, based on approximate depth to water of $526 \mathrm{~m}$ (1992 data) or interpolated directly from borehole deviation survey for the October through December 1999 measurements.
Borehole USW H-6, upper interval, was measured periodically during 1999 with Chain \#3. Water levels fluctuated within a $0.11 \mathrm{I}-\mathrm{m}$ range during 1999 (fig. 58) with the lowest water level being $776.05 \mathrm{~m}$ above sea level (02-02-99) and the highest water level being $776.16 \mathrm{~m}$ above sea level (01-20-99 and 11-16-99) (table 30). The mean water-level altitude of the 1999 data was $776.11 \mathrm{~m}$ above sea level and was within the range of previous annual mean water-level altitudes from 1985 to 1998 (fig. 59). The annual mean water-level altitude has been rising since 1997.

Borehole USW H-6, lower interval, was measured periodically during 1999 with Chain \#3. Water levels fluctuated within a $0.12-\mathrm{m}$ range during 1999 (fig. 60) with the lowest water level being $775.93 \mathrm{~m}$ above sea level (02-02-99) and the highest water level being $776.05 \mathrm{~m}$ above sea level (05-03-99 and 11-16-99) (table 31). The mean water-level altitude of the 1999 data was $775.99 \mathrm{~m}$ above sea level and was within the range of previous annual mean water-level altitudes from 1985 to 1998 (fig. 61). The annual mean water-level altitude has been rising since 1997.

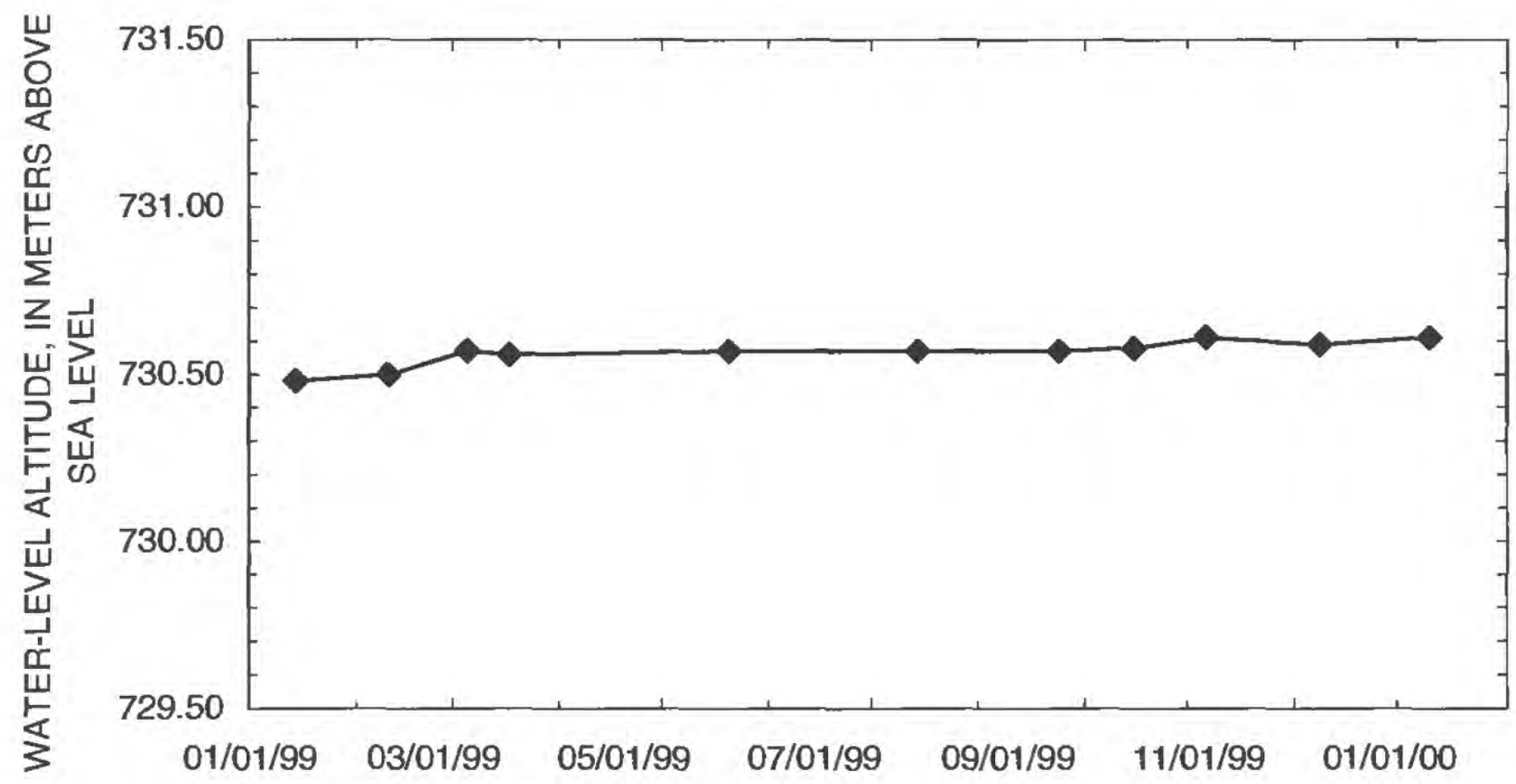

Figure 58. Water-level altitudes for borehole USW H-6, upper interval, during 1999. 
Table 30. Measured water-level altitudes, 1999, for borehole USW H-6, upper interval

\begin{tabular}{lrcr}
\hline Date & Time & $\begin{array}{c}\text { Water-level altitude } \\
\text { (meters above sea } \\
\text { level) }\end{array}$ & $\begin{array}{c}\text { Equlpment used } \\
\text { to measure water } \\
\text { level }\end{array}$ \\
\hline $01 / 20 / 99$ & 1103 & 776.16 & Chain \#3 \\
$02 / 02 / 99$ & 940 & 776.05 & Chain \#3 \\
$03 / 09 / 99$ & 1025 & 776.15 & Chain \#3 \\
$04 / 06 / 99$ & 1101 & 776.12 & Chain \#3 \\
$07 / 20 / 99$ & 1257 & 776.10 & Chain \#3 \\
$08 / 17 / 99$ & 1017 & 776.07 & Chain \#3 \\
$09 / 16 / 99$ & 1147 & 776.12 & Chain \#3 \\
$10 / 19 / 99$ & 1001 & 776.06 & Chain \#3 \\
$11 / 16 / 99$ & 1056 & 776.16 & Chain \#3 \\
$12 / 15 / 99$ & 1119 & 776.06 & Chain \#3 \\
\hline
\end{tabular}

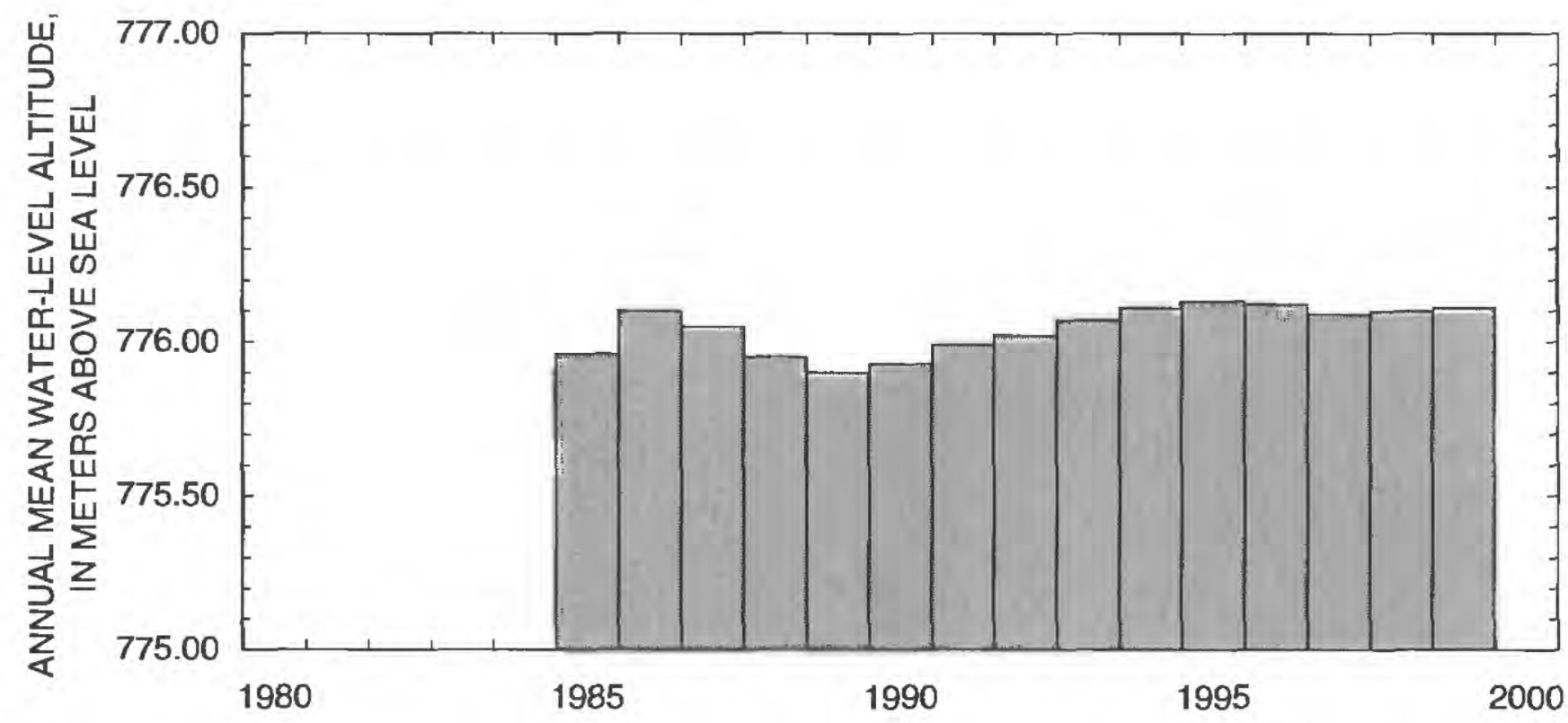

Figure 59. Annual mean water-level altitudes for borehole USW H-6, upper interval.

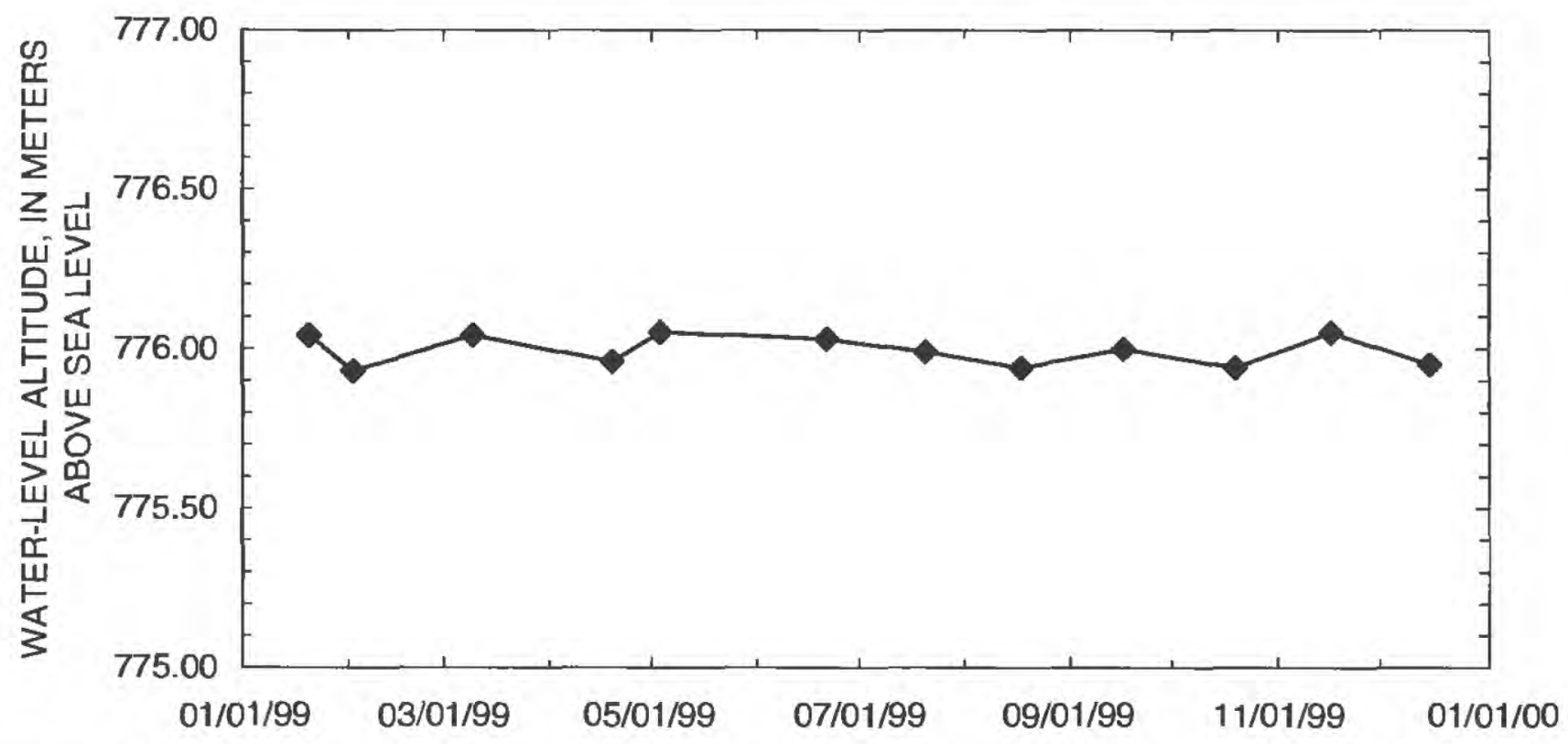

Figure 60. Water-level altitudes for borehole USW H-6, lower interval, during 1999. 
Table 31. Measured water-level altitudes, 1999, for borehole USW H-6, lower interval

\begin{tabular}{cccc}
\hline Date & Time & $\begin{array}{c}\text { Water-level altitude } \\
\text { (metera above sea } \\
\text { level) }\end{array}$ & $\begin{array}{c}\text { Equipment } \\
\text { used to } \\
\text { measure water } \\
\text { level }\end{array}$ \\
\hline $01 / 20 / 99$ & 1137 & 776.04 & Chain \#3 \\
$02 / 02 / 99$ & 1012 & 775.93 & Chain \#3 \\
$03 / 09 / 99$ & 1114 & 776.04 & Chain \#3 \\
$04 / 19 / 99$ & 1001 & 775.96 & Chain \#3 \\
$05 / 03 / 99$ & 957 & 776.05 & Chain \#3 \\
$06 / 21 / 99$ & 958 & 776.03 & Chain \#3 \\
$07 / 20 / 99$ & 1331 & 775.99 & Chain \#3 \\
$08 / 17 / 99$ & 1044 & 775.94 & Chain \#3 \\
$09 / 16 / 99$ & 1122 & 776.00 & Chain \#3 \\
$10 / 19 / 99$ & 1026 & 775.94 & Chain \#3 \\
$11 / 16 / 99$ & 1124 & 776.05 & Chain \#3 \\
$12 / 15 / 99$ & 1051 & 775.95 & Chain \#3 \\
\hline
\end{tabular}

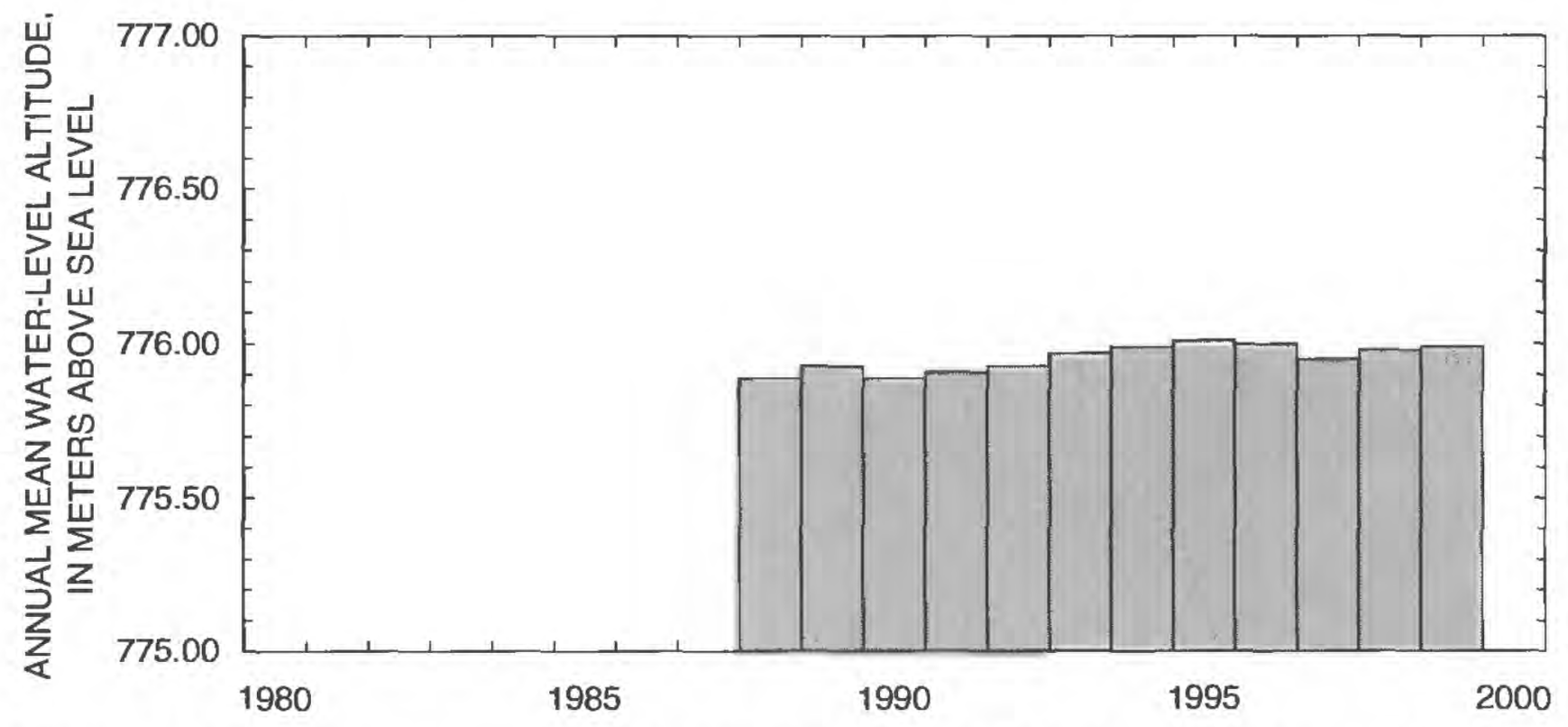

Figure 61. Annual mean water-level altitudes for borehole USW H-6, lower interval. 


\section{Well UE-25 J-11}

\section{Well specifications}

1. Location and identification:

Nevada State Plane North American Datum of

1927 Central Zone Coordinates (meters):

N 225,847; E 186,467 (U.S. Department of

Energy, written commun., 1999,

MO9907YMP99025.001)

Latitude and longitude: $36^{\circ} 47^{\prime} 06^{\prime \prime} \mathrm{N}$.;

$116^{\circ} 17^{\prime} 06^{\prime \prime} \mathrm{W}$. (Converted from Nevada State

Plane North American Datum of 1927 Central

Zone Coordinates)

U.S. Geological Survey Site ID:

364706116170601 .

2. Drilling and casing information:

Well started: June 4, 1957 (Young, 1972, p. 10).

Well completed: July 19, 1957 (Young, 1972, p. 10).

Drilling method: Cable-tool (Young, 1972, p. 10).

Bit diameter, below land surface: $400 \mathrm{~mm}$

(Boucher, 1994b, p. 5).

Casing, below land surface extending below water level: 308-mm-inside-diameter casing extends from land surface to $404.5 \mathrm{~m}$ (Boucher, 1994b, p. 5).

Total drilled depth: $405.38 \mathrm{~m}$ (Young, 1972, p. 10).

3. Description of access tube and depth interval for measuring water levels:

308-mm-inside-diameter casing; the casing is perforated from 328.3 to $334.4 \mathrm{~m}$ and from 379.2 to $396.2 \mathrm{~m}$. The well produces water from the basalt of Kiwi Mesa and from the welded-tuff aquifer, located within the Topopah Spring Tuff of the Paintbrush Group (Boucher, 1994 b, p. 5). Stratigraphic nomenclature presented by Boucher revised to agree with stratigraphic nomenclature in Sawyer and others (1994, p. 1305).

4. Information for calculating water-level altitude:

Reference point: Chiseled " $\mathrm{X}$ " in concrete pad near well; altitude $1,049.45 \mathrm{~m}$ (surveyed by U.S. Geological Survey in 1993) (Boucher, 1994b, p. 5).

Measurement point: Top of casing, even with top of concrete block, $0.555 \mathrm{~m}$ above reference point.

Depth correction for borehole deviation from vertical is not available. The approximate depth to water was $318 \mathrm{~m}$ (1992 data).

Well UE-25 J-11 was measured periodically during 1999 with Chain \#3 and 2,800-foot reference tape. Water levels fluctuated within a $0.14-\mathrm{m}$ range during 1999 (fig. 62) with the lowest water level being $732.20 \mathrm{~m}$ above sea level (04-16-99) and the highest water level being $732.34 \mathrm{~m}$ above sea level (05-13-99) (table 32). The mean water-level altitude of the 1999 data was $732.26 \mathrm{~m}$ above sea level and was greater than the range of previous annual mean waterlevel altitudes from 1989 to 1998 (fig. 63). The annual mean water-level altitude rose from 1998.

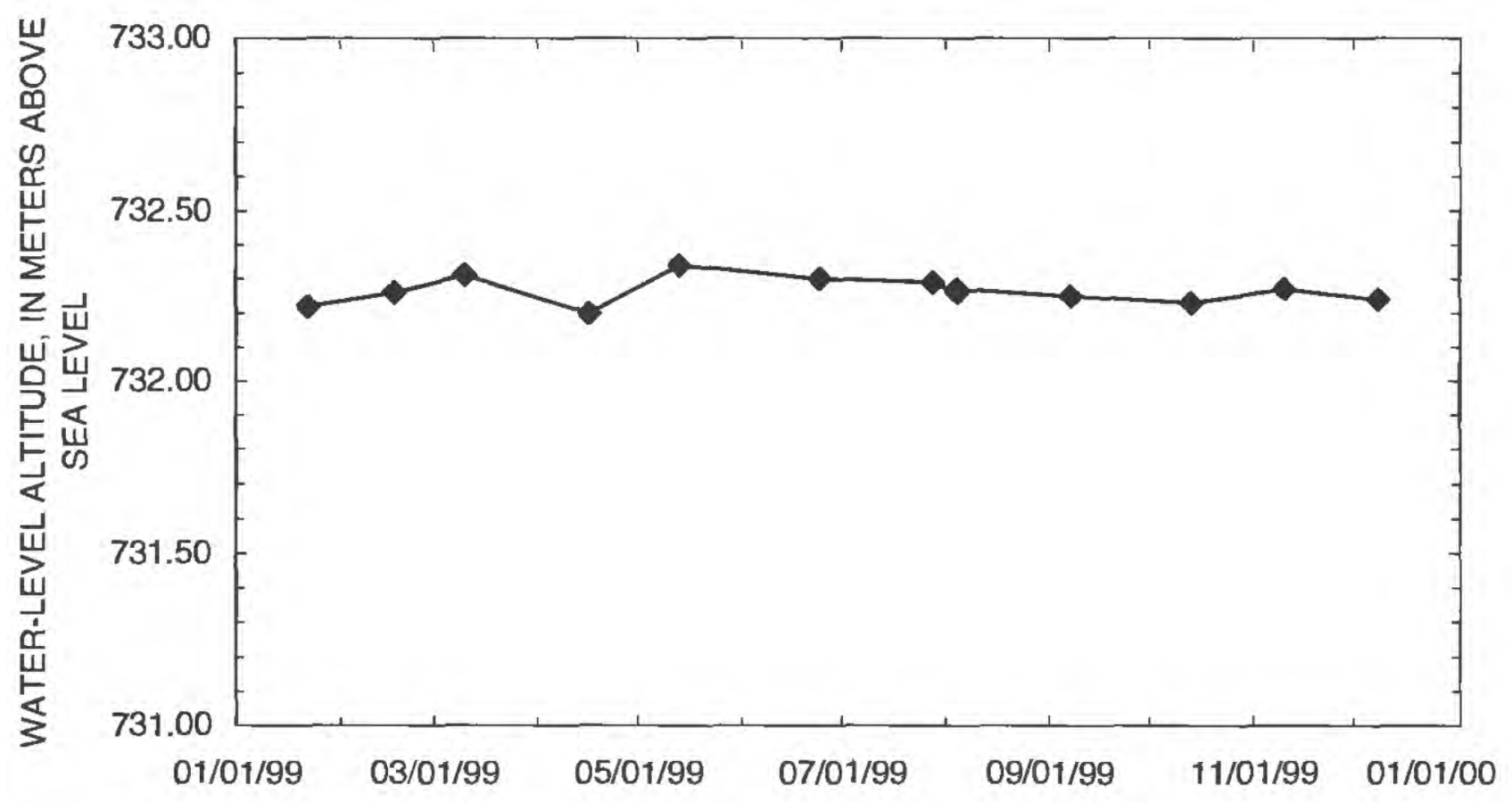

Figure 62. Water-level altitudes for well UE-25 J-11 during 1999. 
Table 32. Measured water-level altitudes, 1999, for well UE-25 J-11

\begin{tabular}{rrrr}
\hline Date & Time & $\begin{array}{c}\text { Water-level altitude } \\
\text { (meters above sea } \\
\text { level) }\end{array}$ & $\begin{array}{r}\text { Equipment used to } \\
\text { measure water level }\end{array}$ \\
\hline $01 / 22 / 99$ & 922 & 732.22 & Chain \#3 \\
$02 / 17 / 99$ & 843 & 732.26 & Chain \#3 \\
$03 / 10 / 99$ & 1546 & 732.31 & Chain \#3 \\
$04 / 16 / 99$ & 1559 & 732.20 & Chain \#3 \\
$05 / 13 / 99$ & 1423 & 732.34 & Chain \#3 \\
$06 / 24 / 99$ & 1517 & 732.30 & Chain \#3 \\
$07 / 28 / 99$ & 1319 & 732.29 & Chain \#3 \\
$08 / 04 / 99$ & 858 & 732.26 & 2,800 -foot reference tape \\
$08 / 04 / 99$ & 1230 & 732.27 & 2,800 -foot reference tape \\
$09 / 07 / 99$ & 1008 & 732.25 & Chain \#3 \\
$10 / 13 / 99$ & 846 & 732.23 & 2,800 -foot reference tape \\
$10 / 13 / 99$ & 1036 & 732.23 & 2.800 -foot reference tape \\
$11 / 10 / 99$ & 1145 & 732.27 & Chain \#3 \\
$12 / 08 / 99$ & 1411 & 732.24 & Chain \#3 \\
\hline
\end{tabular}

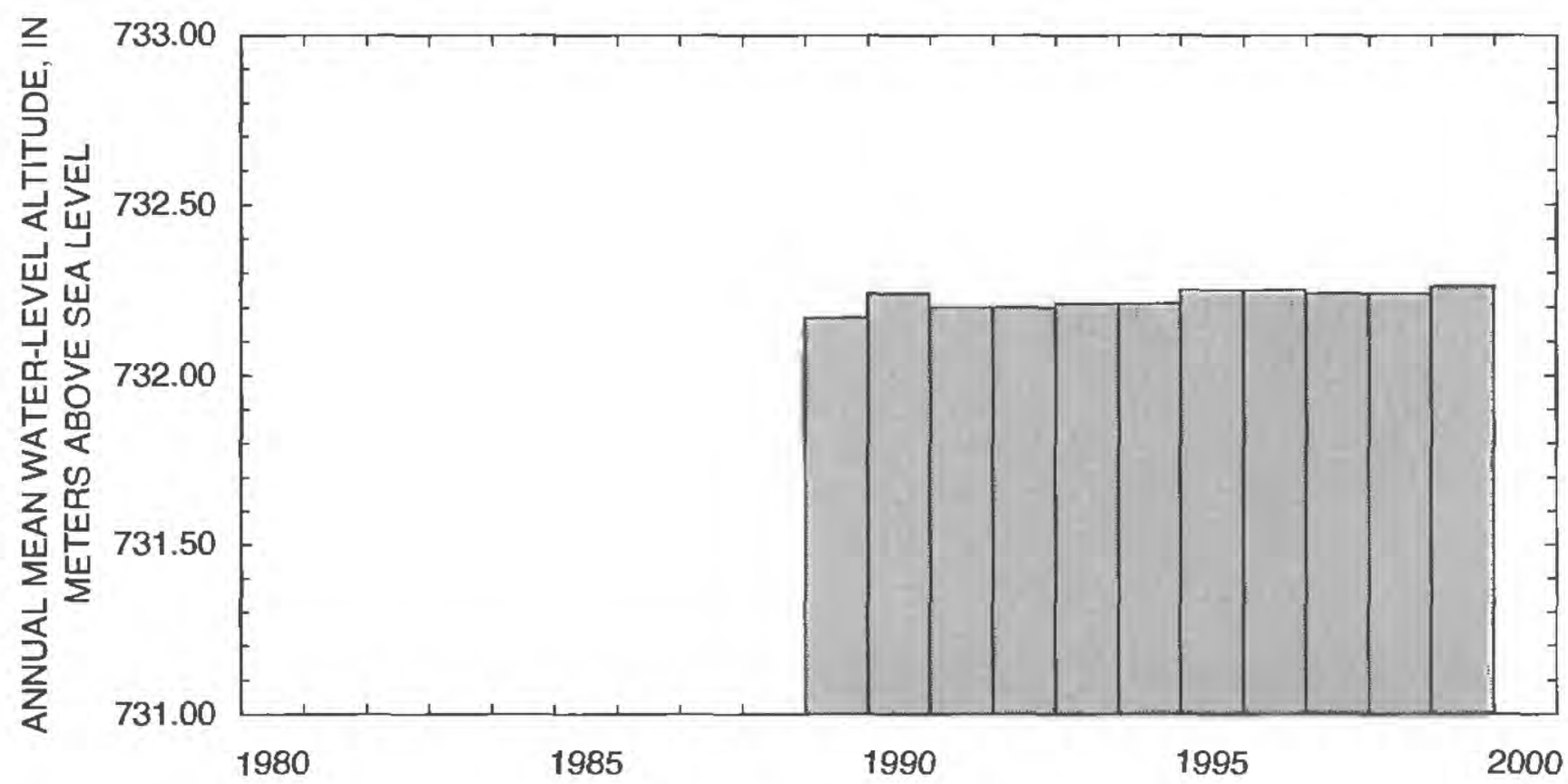

Figure 63. Annual mean water-level altitudes for well UE-25 J-11.

\section{Well UE-25 J-12}

\section{Well specifications}

1. Location and identification:

Nevada State Plane North American Datum of 1927 Central Zone Coordinates (meters): N 223,573; E 177,092 (U.S. Department of Energy, written commun., 1999. MO9907YMP99025.001)

Latitude and longitude: $36^{\circ} 45^{\prime} 54^{\prime \prime} \mathrm{N}$.; $116^{\circ} 23^{\prime} 24^{\prime \prime W}$. (Converted from Nevada State
Plane North American Datum of 1927 Central Zone Coordinates)

U.S. Geological Survey Site ID: 364554116232401.

2. Drilling and casing information:

Well started: August 4, 1957 (Young, 1972, p. 10). Well completed: October 9, 1957 (Young, 1972, p. 10); well was deepened in August 1968 (Boucher, 1994b, p. 6).

Drilling method: Cable-tool (1957) (Young, 1972, p. 10); unknown (1968) (Boucher, 1994b, p. 6). 
Bit diameter, below land surface: $400 \mathrm{~mm}$ to 271 $\mathrm{m} ; 298 \mathrm{~mm}$ to $347 \mathrm{~m}$ (Boucher, 1994b, p. 6).

Casing, below land surface extending below water level: 308-mm-inside-diameter casing extending from land surface to $271 \mathrm{~m}$ (Boucher, 1994b, p. 6).

Total drilled depth: $270.36 \mathrm{~m}$ (1957) (Young, 1972, p. 10); $347 \mathrm{~m}$ after the deepening in 1968 (Boucher, 1994b, p. 6).

3. Description of access tube and depth interval for measuring water levels:

308-mm-inside-diameter casing; the casing is perforated between 241 and $264 \mathrm{~m}$; the hole is open from $271 \mathrm{~m}$ to $347 \mathrm{~m}$; access tube is 54-mm-outside-diameter. The well produces water from the welded-tuff aquifer, located within the Topopah Spring Tuff of the Paintbrush Group (Boucher, 1994b, p. 6). Stratigraphic nomenclature presented by Boucher revised to agree with stratigraphic nomenclature in Sawyer and others (1994, p. 1305).

4. Information for calculating water-level altitude:

Reference point: Top of well collar, altitude $954.54 \mathrm{~m}$ (surveyed by U.S. Geological Survey in 1993) (Boucher, 1994b, p. 6).
Measurement point: Top of the 54-mm-outsidediameter access tube, $0.195 \mathrm{~m}$ above reference point.

Depth correction for borehole deviation from vertical is not available. The approximate depth to water was $227 \mathrm{~m}$ (1992 data).

5. The amount of water pumped from well UE-25 J12 in 1998 was approximately 19.4 million liters, and from January to September 1999 approximately 18.4 million liters (Preissler and others, 1999, p. 573; Jones and others, 2000, p. 200).

Well UE-25 J-12 was measured periodically during 1999 with Chain \#3. Water levels fluctuated within a 0.12-m range during 1999 (fig. 64) with the lowest water level being $727.90 \mathrm{~m}$ above sea level (06-23-99) and the highest water level being $728.02 \mathrm{~m}$ above sea level (03-15-99) (table 33). The mean water-level altitude of the 1999 data was $727.96 \mathrm{~m}$ above sea level and equaled the previous maximum from 1992 (fig. 65). The annual mean water-level altitude rose from 1998.

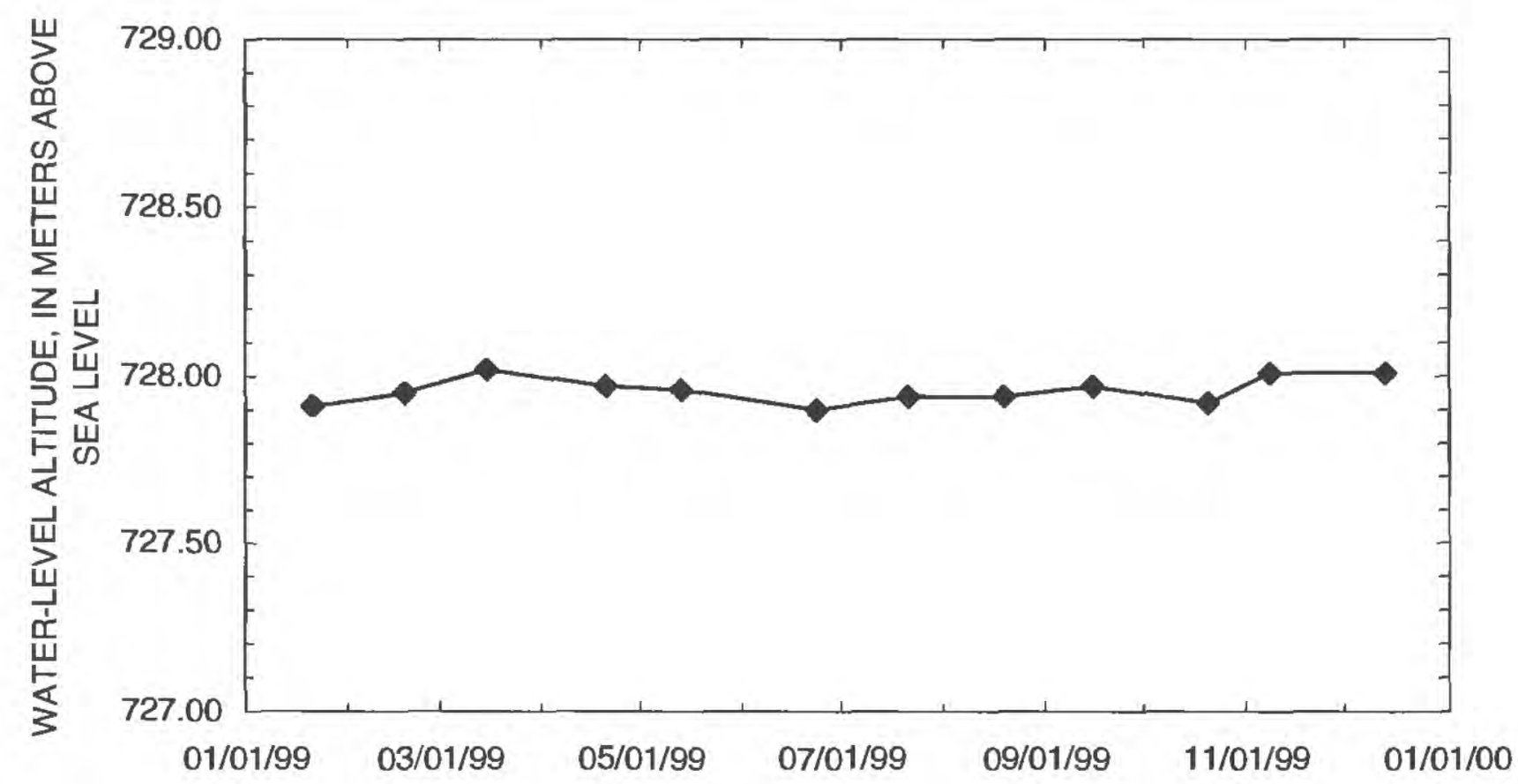

Figure 64. Water-level altitudes for well UE-25 J-12 during 1999. 
Table 33. Measured water-level altitudes, 1999, for well UE-25 J-12

\begin{tabular}{crcc}
\hline Date & Time & $\begin{array}{c}\text { Water-level altitude } \\
\text { (meters above sea } \\
\text { level) }\end{array}$ & $\begin{array}{c}\text { Equipment } \\
\text { used to } \\
\text { measure } \\
\text { water level }\end{array}$ \\
\hline $01 / 21 / 99$ & 911 & 727.91 & Chain \#3 \\
$02 / 18 / 99$ & 1145 & 727.95 & Chain \#3 \\
$03 / 15 / 99$ & 1152 & 728.02 & Chain \#3 \\
$04 / 20 / 99$ & 955 & 727.97 & Chain \#3 \\
$05 / 13 / 99$ & 920 & 727.96 & Chain \#3 \\
$06 / 23 / 99$ & 1038 & 727.90 & Chain \#3 \\
$07 / 21 / 99$ & 1540 & 727.94 & Chain \#3 \\
$08 / 19 / 99$ & 737 & 727.94 & Chain \#3 \\
$09 / 15 / 99$ & 1540 & 727.97 & Chain \#3 \\
$10 / 20 / 99$ & 1254 & 727.92 & Chain \#3 \\
$11 / 08 / 99$ & 1509 & 728.01 & Chain \#3 \\
$12 / 13 / 99$ & 1053 & 728.01 & Chain \#3 \\
\hline
\end{tabular}

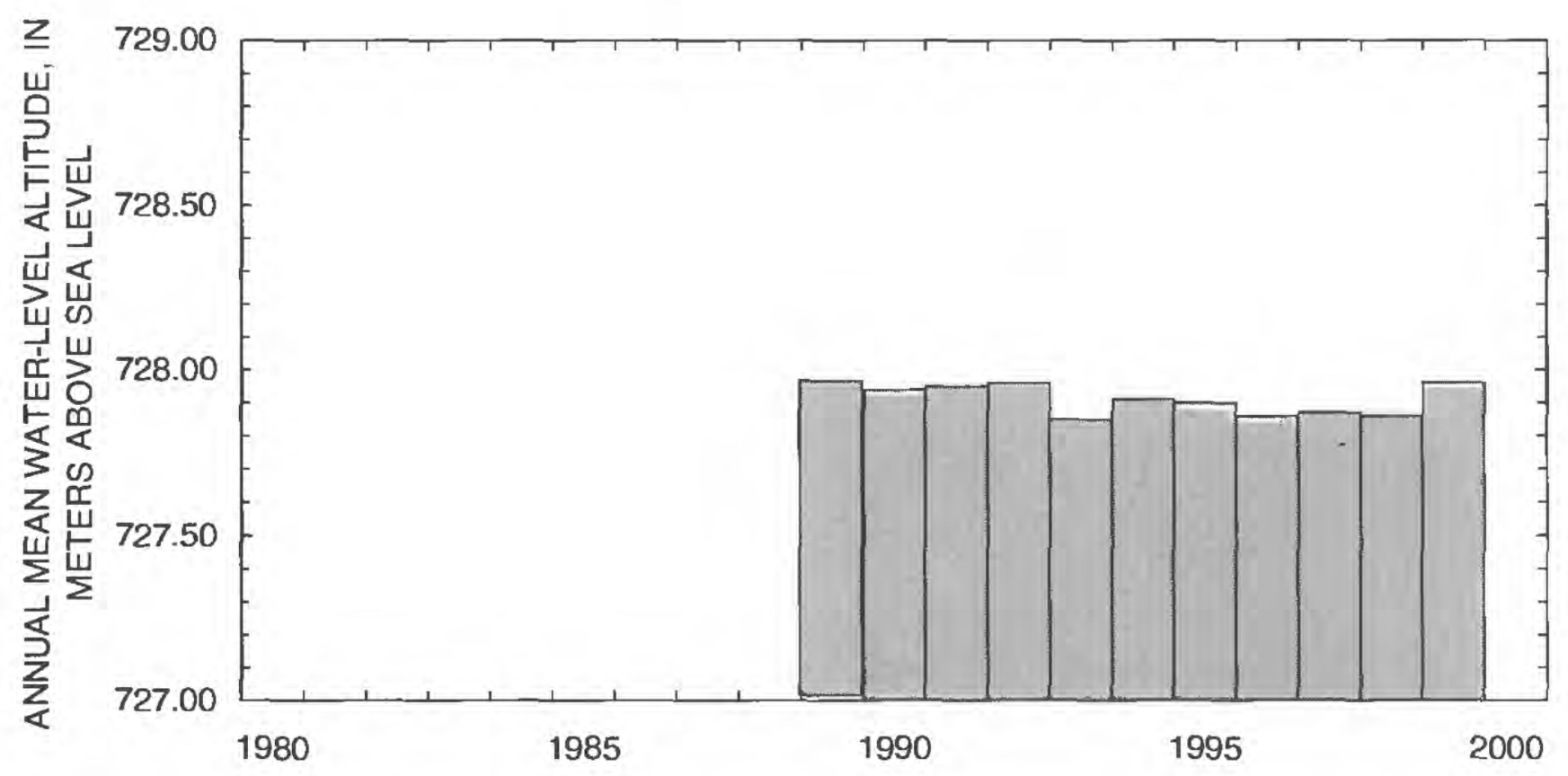

Figure 65. Annual mean water-level altitudes for well UE-25 J-12.

\section{Well UE-25 J-13}

\section{Well specifications}

1. Location and identification:

Nevada State Plane North American Datum of 1927 Central Zone Coordinates (meters): N 228,357; E 176,677 (U.S. Department of Energy, written commun., 1999, MO9907YMP99025.001)

Latitude and longitude: $36^{\circ} 48^{\prime} 29^{\prime \prime} \mathrm{N}$.; $116^{\circ} 23^{\prime} 41^{\prime \prime}$ W. (Converted from Nevada State Plane North American Datum of 1927 Central Zone Coordinates)
U.S. Geological Survey Site ID: 364828116234001 .

2. Drilling and casing information:

Well started: September 1962 (Young, 1972, p. 10).

Well completed: January 1963 (Young, 1972, p. 10).

Drilling method: Rotary air (Young, 1972, p. 10).

Bit diameter, below land surface: $438 \mathrm{~mm}$ to $402 \mathrm{~m} ; 380 \mathrm{~mm}$ from $402 \mathrm{~m}$ to $471 \mathrm{~m}$; $194 \mathrm{~mm}$ from $471 \mathrm{~m}$ to total depth (Robison and others, 1988, p. 128).

Casing, below land surface extending below water level: 323-mm-inside-diameter, from land 
surface to $396.5 \mathrm{~m}$; 282-mm-inside-diameter from 396.5 to $471.2 \mathrm{~m}$; 126 -mm-insidediameter from 452.3 to $1,031.7 \mathrm{~m}$; casing perforated from 303.6 to $423.7 \mathrm{~m}$ is within the Topopah Spring Tuff of the Paintbrush Group and from 819.9 to $1,009.5 \mathrm{~m}$ is within the Tram Tuff of the Crater Flat Group and upper part of the Lithic Ridge Tuff (Robison and others, 1988, p. 128). Stratigraphic nomenclature presented by Robison revised to agree with stratigraphic nomenclature in Sawyer and others (1994,

p. 1305).

Total drilled depth: 1,063.14 m (Young, 1972, p. 10).

3. Description of access tube and depth interval for measuring water levels:

50.8-mm-inside-diameter access tube, installed in 1986, in order for measuring equipment to bypass pump assembly.

4. Information for calculating water-level altitude:

Reference point: Chiseled square on concrete well collar, altitude $1,011.47 \mathrm{~m}$ above reference point (surveyed by U.S. Geological Survey in
1984; Merle E. Southern, National Mapping Division, U.S. Geological Survey, written commun., 1985).

Measurement point: Top of access tube, $0.165 \mathrm{~m}$. Depth correction for borehole deviation from vertical is not available. The approximate depth to water was $283 \mathrm{~m}$ (1992 data).

5 . The amount of water pumped from well UE-25 $\mathrm{J}-13$ in 1998 was approximately 161 million liters, and from January to September 1999, approximately 79.5 million liters (Preissler and others, 1999, p. 573; Jones and others, 2000, p. 200).

Well UE-25 J-13 was measured periodically during 1999 with Chain \#3. Water levels fluctuated within an 0.18-m range during 1999 (fig. 66) with the lowest water level being $728.34 \mathrm{~m}$ above sea level (02-22-99) and the highest water level being $728.52 \mathrm{~m}$ above sea level (03-15-99) (table 34). The mean water-level altitude of the 1999 data was $728.44 \mathrm{~m}$ above sea level and was within the range of previous annual mean water-level altitudes from 1986 to 1998 (fig. 67). The annual mean water-level altitude has been rising since 1997.

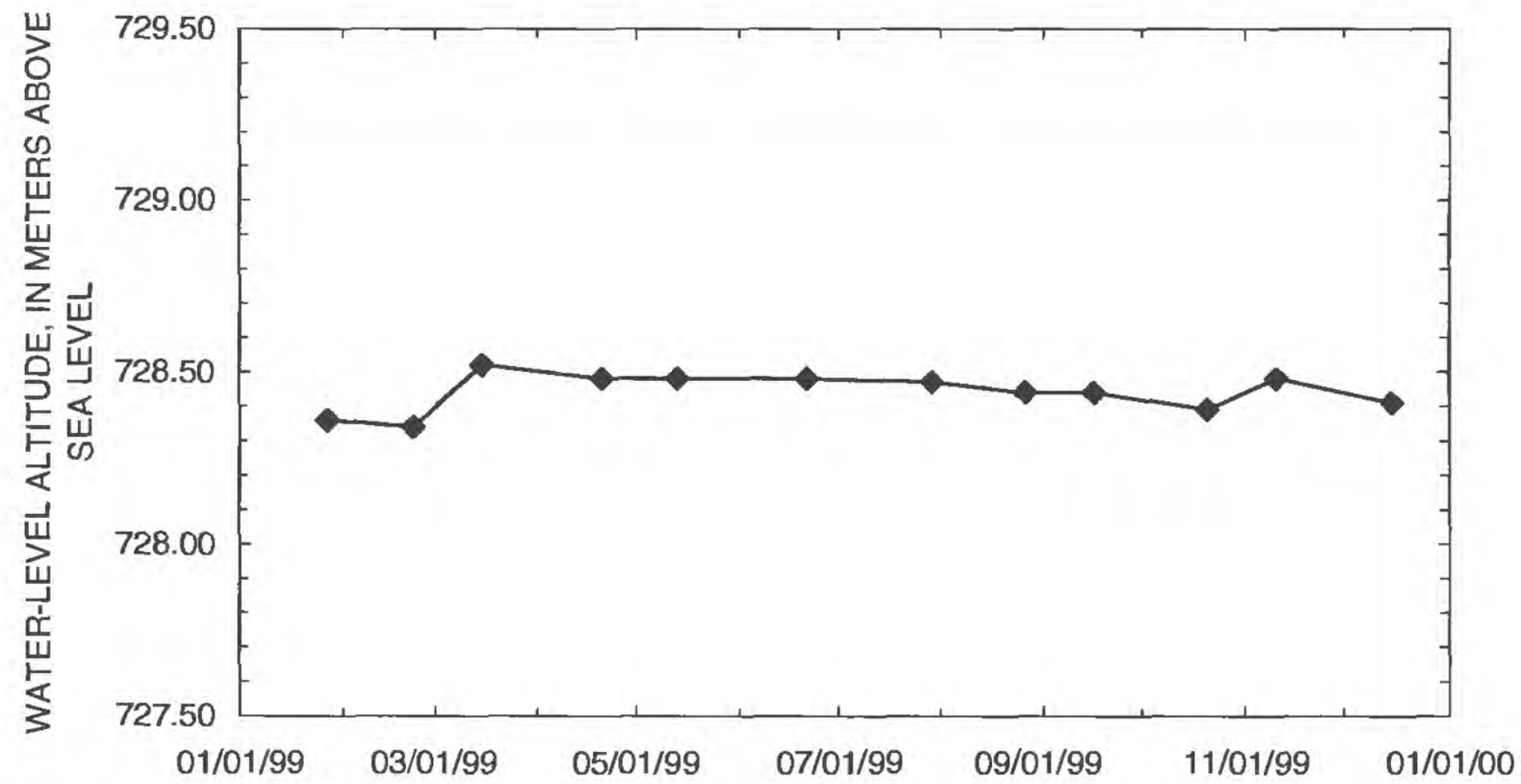

Figure 66. Water-level altitudes for well UE-25 J-13 during 1999. 
Table 34. Measured water-level altitudes, 1999, for well UE-25 J-13

\begin{tabular}{lrcc}
\hline Date & Time & $\begin{array}{c}\text { Water-level altitude } \\
\text { (meters above sea } \\
\text { level) }\end{array}$ & $\begin{array}{c}\text { Equipment } \\
\text { used to } \\
\text { measure } \\
\text { water level }\end{array}$ \\
\hline $01 / 27 / 99$ & 916 & 728.36 & Chain \#3 \\
$02 / 22 / 99$ & 839 & 728.34 & Chain \#3 \\
$03 / 15 / 99$ & 1238 & 728.52 & Chain \#3 \\
$04 / 20 / 99$ & 911 & 728.48 & Chain \#3 \\
$05 / 13 / 99$ & 1515 & 728.48 & Chain \#3 \\
$06 / 21 / 99$ & 734 & 728.48 & Chain \#3 \\
$07 / 29 / 99$ & 831 & 728.47 & Chain \#3 \\
$08 / 26 / 99$ & 1607 & 728.44 & Chain \#3 \\
$09 / 16 / 99$ & 742 & 728.44 & Chain \#3 \\
$10 / 20 / 99$ & 803 & 728.39 & Chain \#3 \\
$11 / 10 / 99$ & 848 & 728.48 & Chain \#3 \\
$12 / 15 / 99$ & 840 & 728.41 & Chain \#3 \\
\hline
\end{tabular}

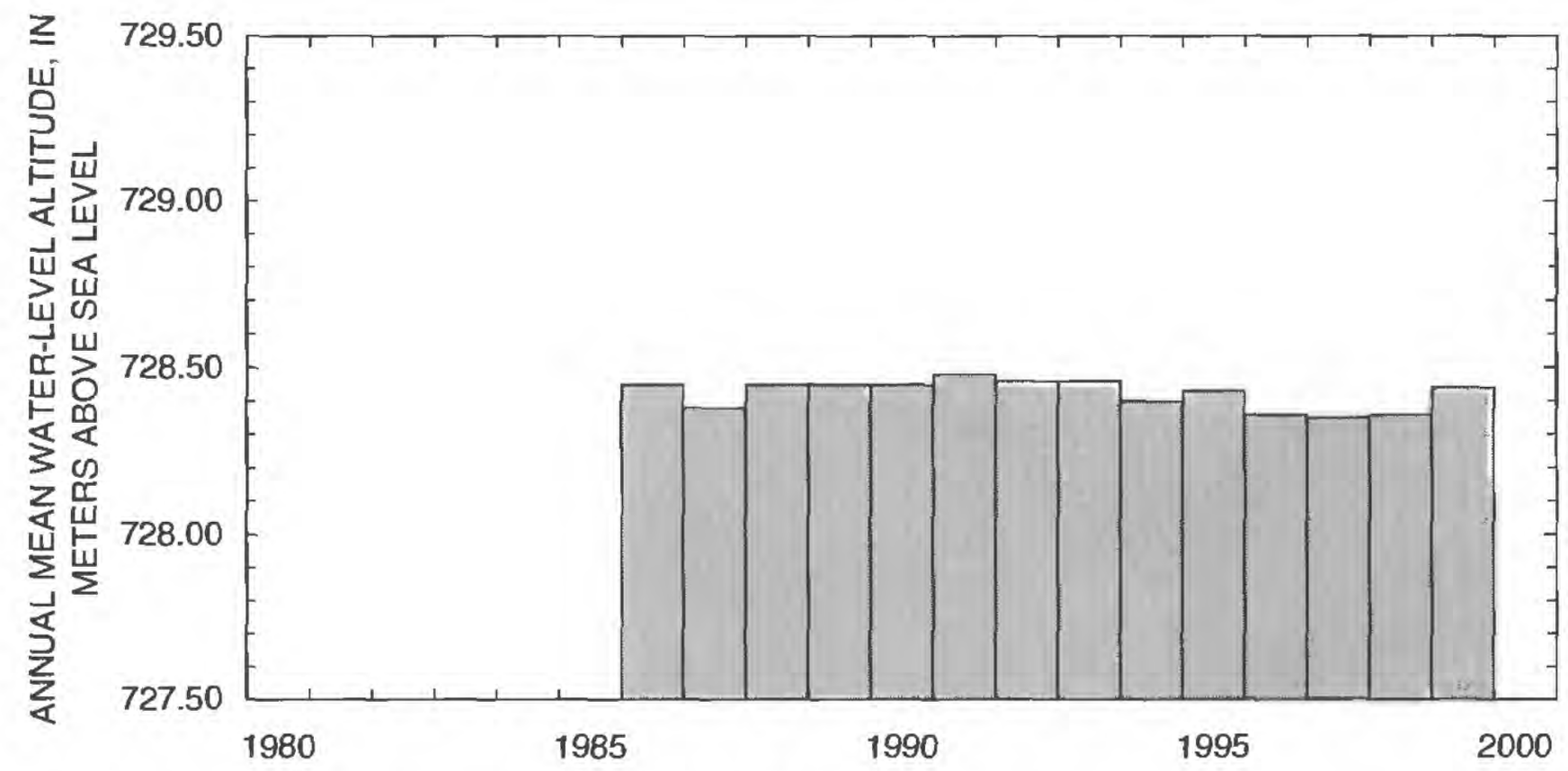

Figure 67. Annual mean water-level altitudes for well UE-25 J-13.

\section{Borehole USW VH-1}

\section{Borehole specifications}

1. Location and identification:

Nevada State Plane North American Datum of 1927 Central Zone Coordinates (meters): N 226,575; E 162,649 (U.S. Department of Energy, written commun., 1999. MO9907YMP99025.001)

Latitude and longitude: $36^{\circ} 47^{\prime} 32^{\prime \prime} \mathrm{N}$.;

$116^{\circ} 33^{\prime} 07^{\prime \prime} W$. (Converted from Nevada State Plane North American Datum of 1927 Central Zone Coordinates)

U.S. Geological Survey Site ID: 364732116330701 .
2. Drilling and casing information:

Borehole started: October 28, 1980 (Fenix \& Scisson, Inc., 1986c. p. 3).

Borehole completed: February 18, 1981 (Fenix \& Scisson, Inc., 1986c, p. 3).

Drilling method: Rotary, using rock bits and an air-foam and polymer circulating medium (Robison and others, 1988, p. 125).

Bit diameter, below land surface: 0 to $15.85 \mathrm{~m}$, $311.15 \mathrm{~mm}$; 15.85 to $277.98 \mathrm{~m}, 222.25 \mathrm{~mm}$; 277.98 to $762.30 \mathrm{~m}, 158.75 \mathrm{~mm}$ (Fenix \& Scisson, Inc., 1986c, p. 3).

Casing, below land surface: 0 to $14.63 \mathrm{~m}$, 226.59-mm-inside-diameter; 0 to $277.54 \mathrm{~m}$, 177.01-mm-inside-diameter (Fenix \& Scisson, Inc., 1986c p. 3). 
Total drilled depth: 762.30 m (Fenix \& Scisson, Inc., 1986c, p. 3).

3. Description of access tube and depth interval for measuring water levels:

48-mm-inside-diameter tubing, open ended (Robison and others, 1988, p. 125) from land surface to $205.4 \mathrm{~m}$ (Fenix \& Scisson, Inc., 1986c, p. 3); saturated interval of the borehole is within the Tiva Canyon and Topopah Spring Tuffs of the Paintbrush Group and the Prow Pass and Bullfrog Tuffs of the Crater Flat Group (Robison and others, 1988, p. 125). Stratigraphic nomenclature presented by Robison revised to agree with stratigraphic nomenclature in Sawyer and others (1994, p. 1305).

A pump was installed in the borehole on July 8, 1982, at a depth of $211.84 \mathrm{~m}$ (Fenix \& Scisson, Inc., 1986c, p. 3).

4. Information for calculating water-level altitude:

Reference point: Top of metal tag on well casing, altitude $963.23 \mathrm{~m}$ (surveyed by Holmes \& Narver, Inc., March 3, 1986).
Measurement point: Top of access tube, $0.631 \mathrm{~m}$ above reference point.

Depth correction for borehole deviation from vertical: Computed from borehole deviation survey dated December $24,1980,-0.049 \mathrm{~m}$, based on approximate depth to water of $184 \mathrm{~m}$ (1992 data) or interpolated directly from borehole deviation survey for the October through December 1999 measurements.

Borehole USW VH-1 was measured periodically during 1999 with Chain \#3. Water levels fluctuated within a 0.12-m range during 1999 (fig. 68) with the lowest water level being $779.45 \mathrm{~m}$ above sea level (12-15-99) and the highest water level being $779.57 \mathrm{~m}$ above sea level (05-03-99) (table 35). The mean water-level altitude of the 1999 data was $779.52 \mathrm{~m}$ above sea level and was a new maximum annual mean water-level altitude in comparison to the range of previous annual mean water-level altitudes from 1985 to 1998 (fig. 69). Annual mean water-level altitudes have been rising since 1997.

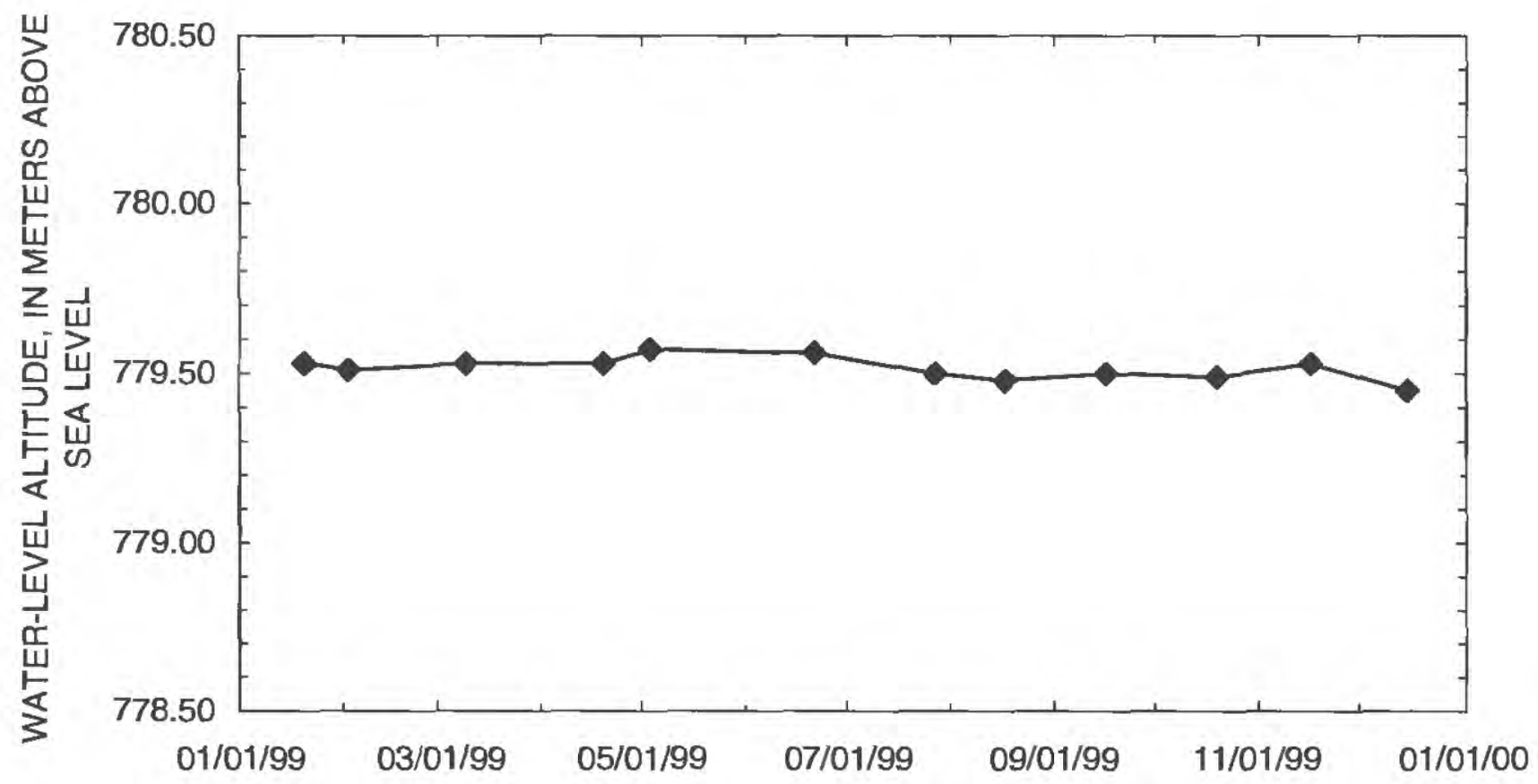

Figure 68. Water-level altitudes for borehole USW VH-1 during 1999. 
Table 35. Measured water-level altitudes, 1999, for borehole USW VH-1

\begin{tabular}{crcc}
\hline Date & Time & $\begin{array}{c}\text { Water-level altitude } \\
\text { (meters above sea } \\
\text { level) }\end{array}$ & $\begin{array}{c}\text { Equipment } \\
\text { used to } \\
\text { measure } \\
\text { water level }\end{array}$ \\
\hline $01 / 20 / 99$ & 855 & 779.53 & Chain \#3 \\
$02 / 02 / 99$ & 1421 & 779.51 & Chain \#3 \\
$03 / 09 / 99$ & 1408 & 779.53 & Chain \#3 \\
$04 / 19 / 99$ & 1406 & 779.53 & Chain \#3 \\
$05 / 03 / 99$ & 1339 & 779.57 & Chain \#3 \\
$06 / 21 / 99$ & 1426 & 779.56 & Chain \#3 \\
$07 / 27 / 99$ & 1144 & 779.50 & Chain \#3 \\
$08 / 17 / 99$ & 849 & 779.48 & Chain \#3 \\
$09 / 16 / 99$ & 1003 & 779.50 & Chain \#3 \\
$10 / 19 / 99$ & 901 & 779.49 & Chain \#3 \\
$11 / 16 / 99$ & 1007 & 779.53 & Chain \#3 \\
$12 / 15 / 99$ & 954 & 779.45 & Chain \#3 \\
\hline
\end{tabular}

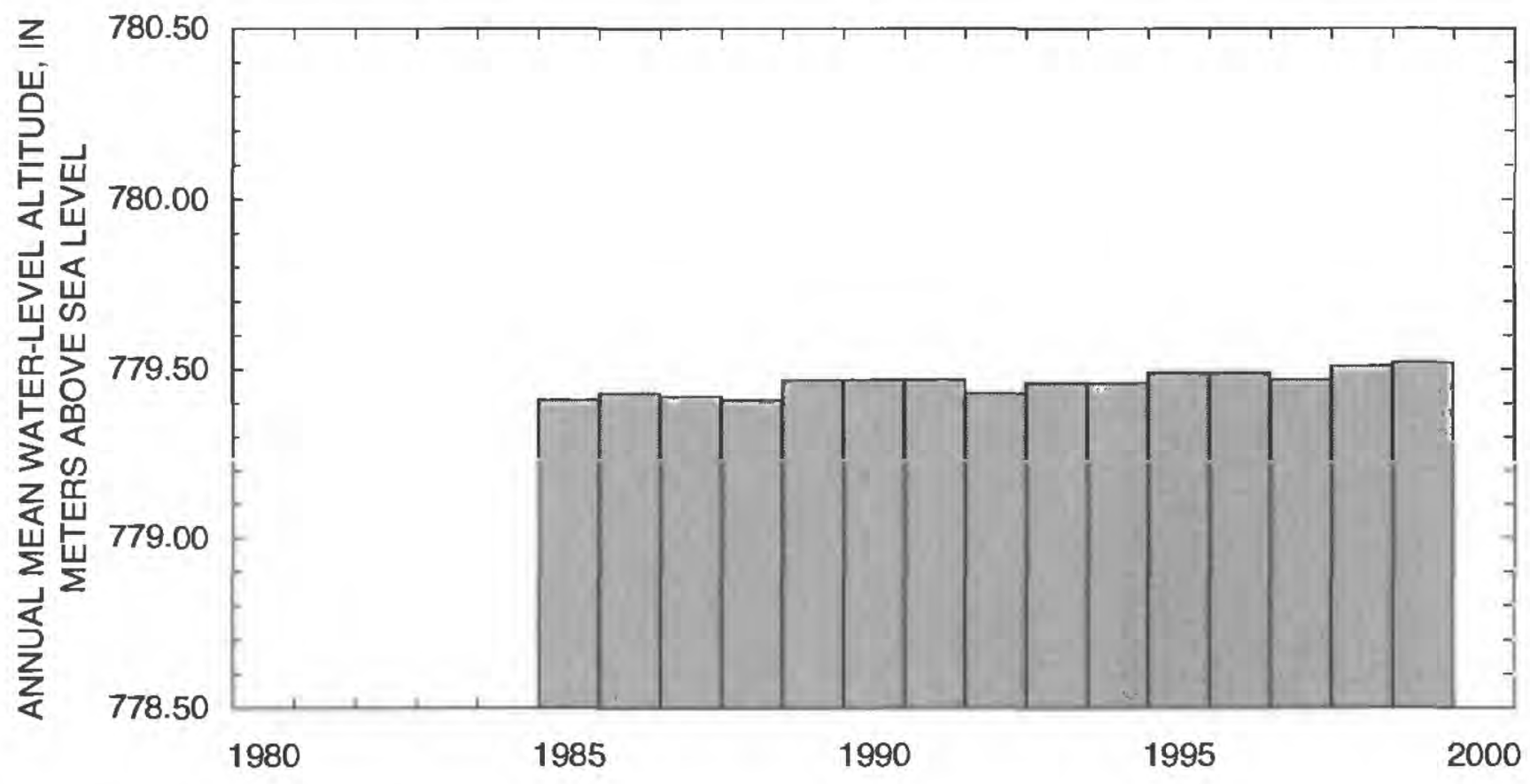

Figure 69. Annual mean water-level altitudes for borehole USW VH-1.

\section{Borehole UE-29 a \#1}

\section{Well specifications}

\section{Location and identification:}

Nevada State Plane North American Datum of 1927 Central Zone Coordinates (meters): N 243,148; E 178,483 (U.S. Department of Energy, written commun., 1999 , MO9907YMP99025.001)

Latitude and longitude: $36^{\circ} 56^{\prime} 29^{\prime \prime} \mathrm{N}$.; $116^{\circ} 22^{\prime 2} 26^{\prime \prime W}$. (Converted from Nevada State Plane North American Datum of 1927 Central Zone Coordinates)
U.S. Geological Survey Site ID: 365629116222601.

2. Drilling and casing information:

Well started: September 1981 (Fenix \& Scisson, Inc., 1986d, p. 3).

Well completed: October 1981 (Fenix \& Scisson, Inc., 1986d, p. 3).

Drilling method: Rotary air foam (Fenix \& Scisson. Inc., 1986d, p. 3).

Bit diameter, below land surface: $914 \mathrm{~mm}$ to $11.6 \mathrm{~m} ; 660 \mathrm{~mm}$ from $11.6 \mathrm{~m}$ to $65.5 \mathrm{~m}$ (Fenix \& Scisson, Inc., 1986d, p. 3).

Casing, below land surface: 762-mm-inside-diameter, from land surface to $10.7 \mathrm{~m}$; uncased hole 
from 10.7 to $65.5 \mathrm{~m}$ is not lithologically logged but assumed to be similar as nearby UE-29 a \#2.

Total drilled depth: 65.5 m (Fenix \& Scisson, Inc., 1986d, p. 3).

3. Description of access tube and depth interval for measuring water levels:

Surface casing extended Feb. 15, 1995. 140-mm access hole on top of 762-mm casing cover. Access hole is over uncased hole from 10.7 to $65.5 \mathrm{~m}$.

4. Information for calculating water-level altitude:

Reference point: Marked flat spot on casing extension weld on southwest side of 18 -inch casing. Reference point is at land surface. Land surface surveyed by Yucca Mountain contractor at $1,214.38 \mathrm{~m}$ above sea level (U.S. Department of Energy, written commun., 1999. MO9907YMP99025.001)
Measurement point: Top of 140-mm access hole with cape removed, $0.750 \mathrm{~m}$ above reference point.

Depth correction for borehole deviation from vertical is not needed, measuring equipment hangs straight in large diameter borehole.

Borehole UE-29 a \#1 was measured periodically during 1999 with the add steel tape 1 . Water levels declined throughout 1999 within a 0.65 -m range (fig. 70) with the lowest water level being $1,187.77 \mathrm{~m}$ above sea level (09-23-99) and the highest water level being $1188.42 \mathrm{~m}$ above sea level (01-07-99) (table 36). The mean water-level altitude of the 1999 data was $1,187.99 \mathrm{~m}$ above sea level. The annual mean water-level altitude has not been computed prior to 1999. Water levels in this borehole usually rise after streamflow events in Fortymile Wash or Pah Canyon Wash (Savard, 1998, page 10).

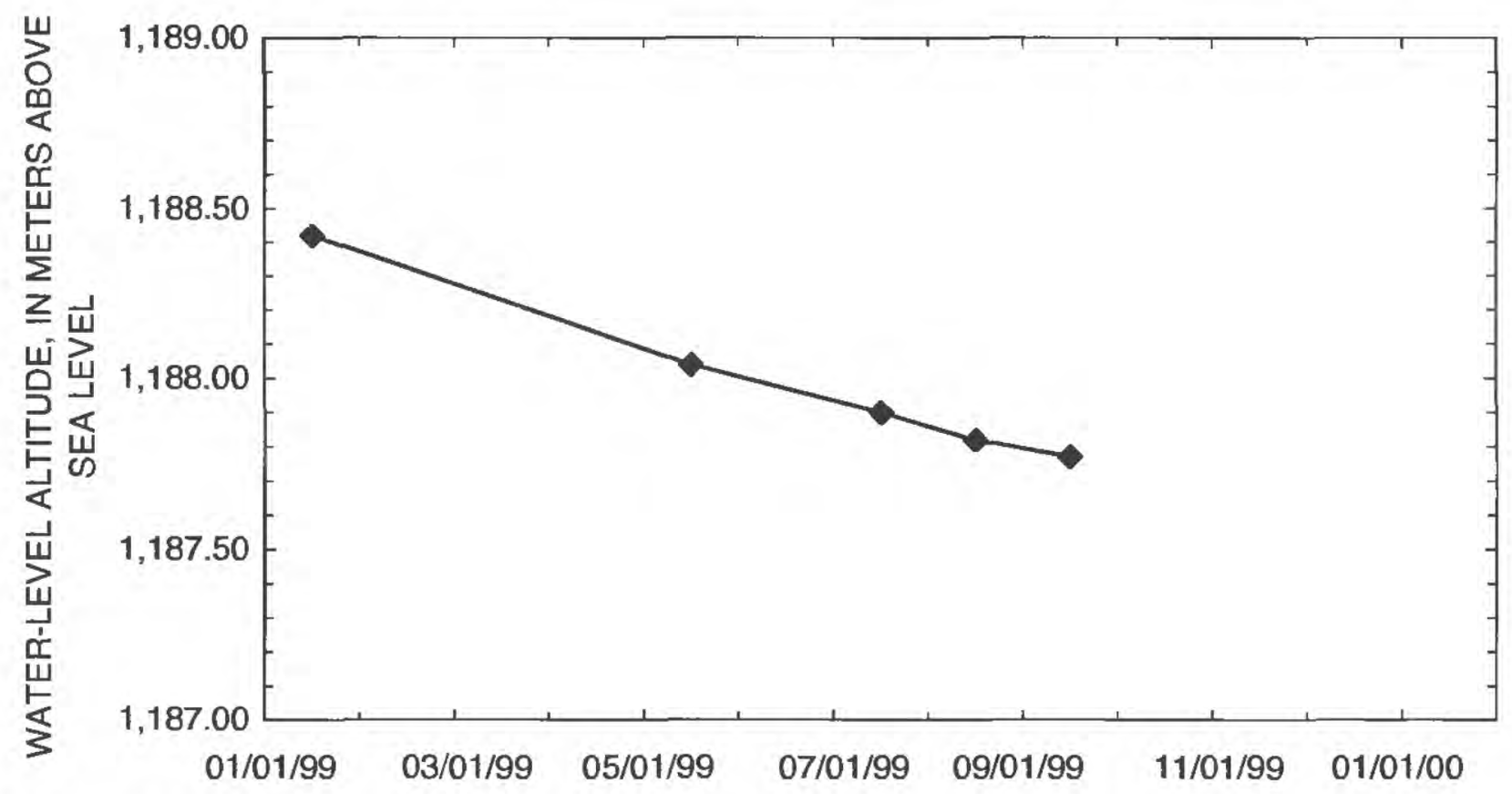

Figure 70. Water-level altitudes for borehole UE-29 a \#1 during 1999.

Table 36. Measured water-level altitudes, 1999, for borehole UE-29 a \#1

\begin{tabular}{cccc}
\hline Date & Time & $\begin{array}{c}\text { Water-level altitude } \\
\text { (meters above sea } \\
\text { level) }\end{array}$ & $\begin{array}{c}\text { Equipment } \\
\text { used to } \\
\text { measure } \\
\text { water level }\end{array}$ \\
\hline $01 / 07 / 99$ & 1015 & $1,188.42$ & STA-1 \\
$05 / 04 / 99$ & 1002 & $1,188.04$ & STA-1 \\
$07 / 14 / 99$ & 1100 & $1,187.90$ & STA-1 \\
$08 / 18 / 99$ & 943 & $1,187.82$ & STA-1 \\
$09 / 23 / 99$ & 1421 & $1,187.77$ & STA-1 \\
\hline
\end{tabular}




\section{Borehole UE-29 a \#2}

\section{Well specifications}

1. Location and identification:

Nevada State Plane North American Datum of 1927 Central Zone Coordinates (meters): N 243,153; E 178,475 (U.S. Department of Energy, written commun., 1999, MO9907YMP99025.001)

Latitude and longitude: $36^{\circ} 56^{\prime} 29^{\prime \prime} \mathrm{N}$.; $116^{\circ} 22^{\prime} 26^{\prime \prime} W$. (Converted from Nevada State Plane North American Datum of 1927 Central Zone Coordinates)

U.S. Geological Survey Site ID: 365629116222602.

2. Drilling and casing information:

Well started: October 1981 (Fenix \& Scisson, Inc., 1986d, p. 9).

Well completed: December 1981 (Fenix \& Scisson, Inc., 1986d, p. 9).

Drilling method: Rotary polymer and air foam (Fenix \& Scisson. Inc., 1986d, p. 9).

Bit diameter, below land surface: $914 \mathrm{~mm}$ to $12.2 \mathrm{~m} ; 660 \mathrm{~mm}$ from $12.2 \mathrm{~m}$ to $48.8 \mathrm{~m}$ : $470 \mathrm{~mm}$ from $48.8 \mathrm{~m}$ to $89.9 \mathrm{~m} ; 375 \mathrm{~mm}$ from $48.8 \mathrm{~m}$ to $248 \mathrm{~m} ; 381 \mathrm{~mm}$ from $248 \mathrm{~m}$ to $355 \mathrm{~m} ; 251 \mathrm{~mm}$ from $355 \mathrm{~m}$ to $421 \mathrm{~m}$ (Fenix \& Scisson, Inc., 1986d, p. 9).

Casing, below land surface extending below water level: 762-mm-inside-diameter, from land surface to $11.9 \mathrm{~m} ; 508$ - $\mathrm{mm}$-inside-diameter from land surface to $48.8 \mathrm{~m}$; 406-mm-inside-diameter from land surface to $86.6 \mathrm{~m} ; 255-\mathrm{mm}$ inside diameter from land surface to $247 \mathrm{~m}$ (Fenix \& Scisson, Inc., 1986d, p. 9); casing perforated from 86.9 to $144.5 \mathrm{~m}$ (Fenix \& Scisson, Inc., 1986d, p. 17) is within the Calico Hills Formation (Waddell, 1984, table 1). Stratigraphic nomenclature presented by
Waddell revised to agree with stratigraphic nomenclature in Sawyer and others (1994, p. 1305).

Total drilled depth: $421 \mathrm{~m}$ (Fenix \& Scisson. Inc.. 1986d, p. 9).

3. Description of access tube and depth interval for measuring water levels:

40-mm access tube on top of 457-mm casing extension added February 15, 1995. Slot in interior casing cover used to access $255-\mathrm{mm}$ casing measuring interval.

4. Information for calculating water-level altitude:

Reference point: Marked " $\mathrm{X}$ " on plate welded to top of 457-mm casing, altitude $1,214.66 \mathrm{~m}$, and $0.146 \mathrm{~m}$ above land surface. Land surface surveyed by Yucca Mountain contractor at 1,214.518 $\mathrm{m}$ above sea level (U.S. Department of Energy, written commun., 1999, MO9907YMP99025.001).

Measurement point: Top of 140-mm access hole on top of $457-\mathrm{mm}$ casing extension; $0.768 \mathrm{~m}$ above land surface.

Depth correction for borehole deviation from vertical is not needed, short depths to water do not require correction. A borehole deviation survey was conducted but is not utilized.

Borehole UE-29 a \#2 was measured periodically during 1999 with the add steel tape 1 . Water levels declined throughout 1999 within a $0.56-\mathrm{m}$ range (fig. 71) with the lowest water level being $1,186.32 \mathrm{~m}$ above sea level (09-23-99) and the highest water level being 1,186.88 $\mathrm{m}$ above sea level (01-07-99) (table 37). The mean water-level altitude of the 1999 data was $1,186.49 \mathrm{~m}$ above sea level. The annual mean water-level altitude was not computed prior to 1999 . Water levels in this borehole usually rise after streamflow events in Fortymile Wash or Pah Canyon Wash (Savard, 1998, page 10). 


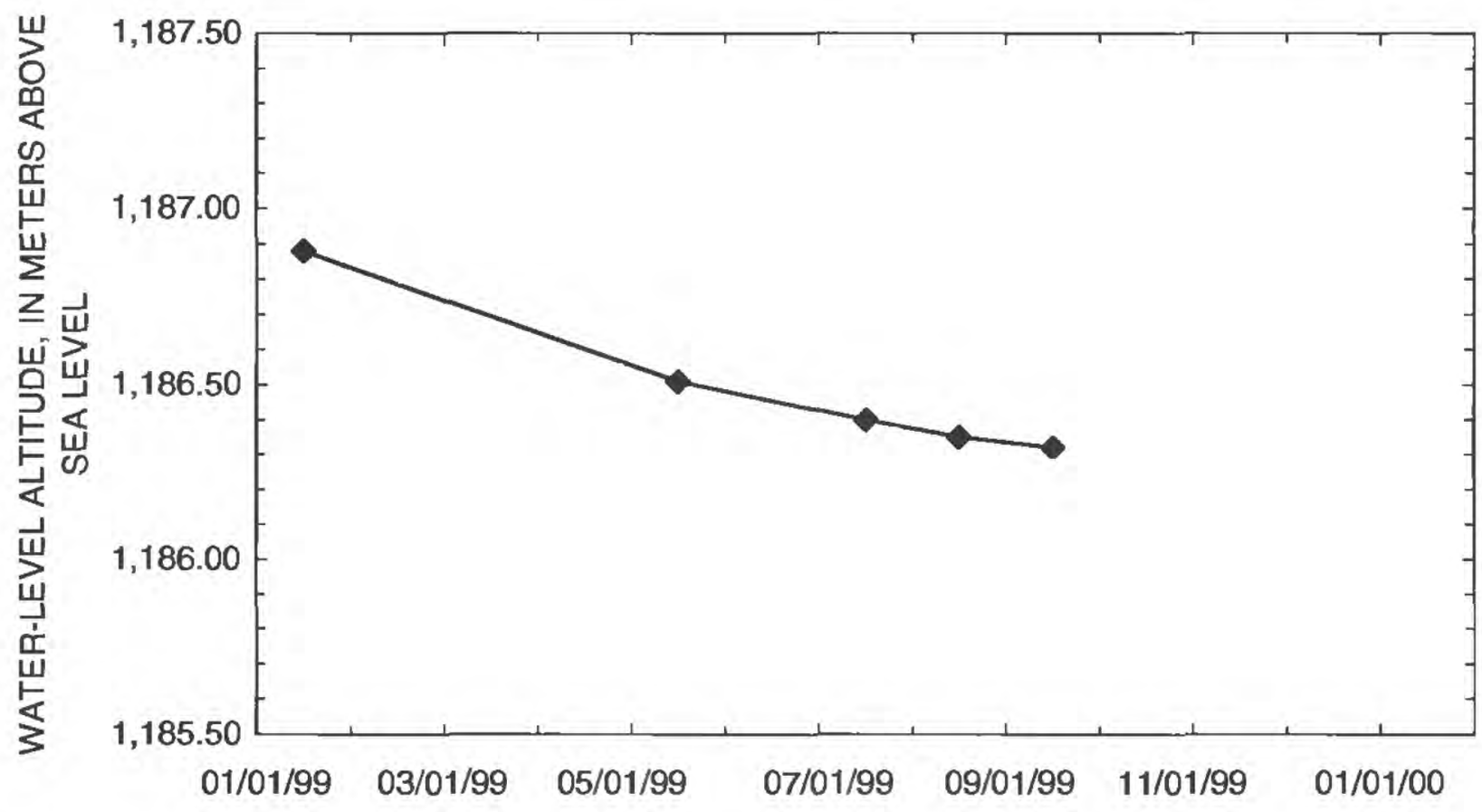

Figure 71. Water-level altitudes for borehole UE-29 a \#2 during 1999.

Table 37. Measured water-level altitudes, 1999, for borehole UE-29 a \#2

\begin{tabular}{cccc}
\hline Date & Time & $\begin{array}{c}\text { Water-level altitude } \\
\text { (meters above sea } \\
\text { level) }\end{array}$ & $\begin{array}{c}\text { Equipment } \\
\text { used to } \\
\text { measure } \\
\text { water level }\end{array}$ \\
\hline $01 / 07 / 99$ & 1021 & $1,186.88$ & STA-1 \\
$05 / 04 / 99$ & 1008 & $1,186.51$ & STA-1 \\
$07 / 14 / 99$ & 1106 & $1,186.40$ & STA-1 \\
$08 / 18 / 99$ & 951 & $1,186.35$ & STA-1 \\
$09 / 23 / 99$ & 1426 & $1,186.32$ & STA-1 \\
\hline
\end{tabular}

\section{Borehole UE-29 UZN \#91}

\section{Well specifications}

1. Location and identification:

Nevada State Plane North American Datum of 1927 Central Zone Coordinates (meters): N 243,010; E 178,412 (U.S. Department of Energy, written commun., 1999, MO9907YMP99025.001)

Latitude and longitude: $36^{\circ} 56^{\prime} 24^{\prime \prime} \mathrm{N}$.; $116^{\circ} 22^{\prime} 28^{\prime \prime} \mathrm{W}$. (Converted from Nevada State Plane North American Datum of 1927 Central Zone Coordinates)

U.S. Geological Survey Site ID: 365624116222901 .

2. Drilling and casing information:

Well started: January 1986 (Fenix \& Scisson, Inc., 1987b, p. 271).
Well completed: January 1986 (Fenix \& Scisson, Inc., 1987b, p. 271).

Drilling method: Air drive (Fenix \& Scisson, Inc., 1987b, p. 271).

Bit diameter, below land surface: $152 \mathrm{~mm}$ to $27 \mathrm{~m}$; and $108 \mathrm{~mm}$ from $27 \mathrm{~m}$ to total depth (Fenix \& Scisson, Inc., 1987b, p. 271).

Casing, below land surface extending below water level: $127-\mathrm{mm}$ inside diameter, from land surface to $27.1 \mathrm{~m}$; open hole from $27.1 \mathrm{~m}$ to total depth is within undifferentiated ash-flow tuff (Blout and others, 1994, p. 62).

Total drilled depth: 28.6 m (Fenix \& Scisson, Inc., 1987b, p. 271).

3. Description of depth interval for measuring water levels:

127-mm-inside-diameter casing driven in borehole during drilling, open borehole below 
casing from 27.1 to $28.6 \mathrm{~m}$ (Fenix \& Scisson, Inc., 1987b, p. 273).

4. Information for calculating water-level altitude:

Reference point: Marked point on joint of outside of $127-\mathrm{mm}$ inside diameter casing at land surface. Land surface surveyed by Yucca Mountain contractor at $1,203.76 \mathrm{~m}$ (U.S.

Department of Energy, 1999, written commun., MO9907YMP99025.001).

Measurement point: Top of $127-\mathrm{mm}$ inside diameter casing with cap removed, $0.610 \mathrm{~m}$ above reference point and land surface. $0.610 \mathrm{~m}$ casing extension added April 5, 1995.
Depth correction for borehole deviation from vertical is not available.

Borehole UE-29 UZN \#91 was measured periodically during 1999 with add steel tape 1. Water levels declined throughout 1999 within a 0.56-m range (fig. 72) with the lowest water level being $1,186.99 \mathrm{~m}$ above sea level (09-23-99) and the highest water level being 1,187.55 $\mathrm{m}$ above sea level (01-07-99)

(table 38). The mean water-level altitude of the 1999 data was 1,187.17 $\mathrm{m}$ above sea level. The annual mean water-level altitude was not computed prior to 1999. Water levels in this borehole usually rise after streamflow events in Fortymile Wash or Pah Canyon Wash (Savard, 1998, page 10).

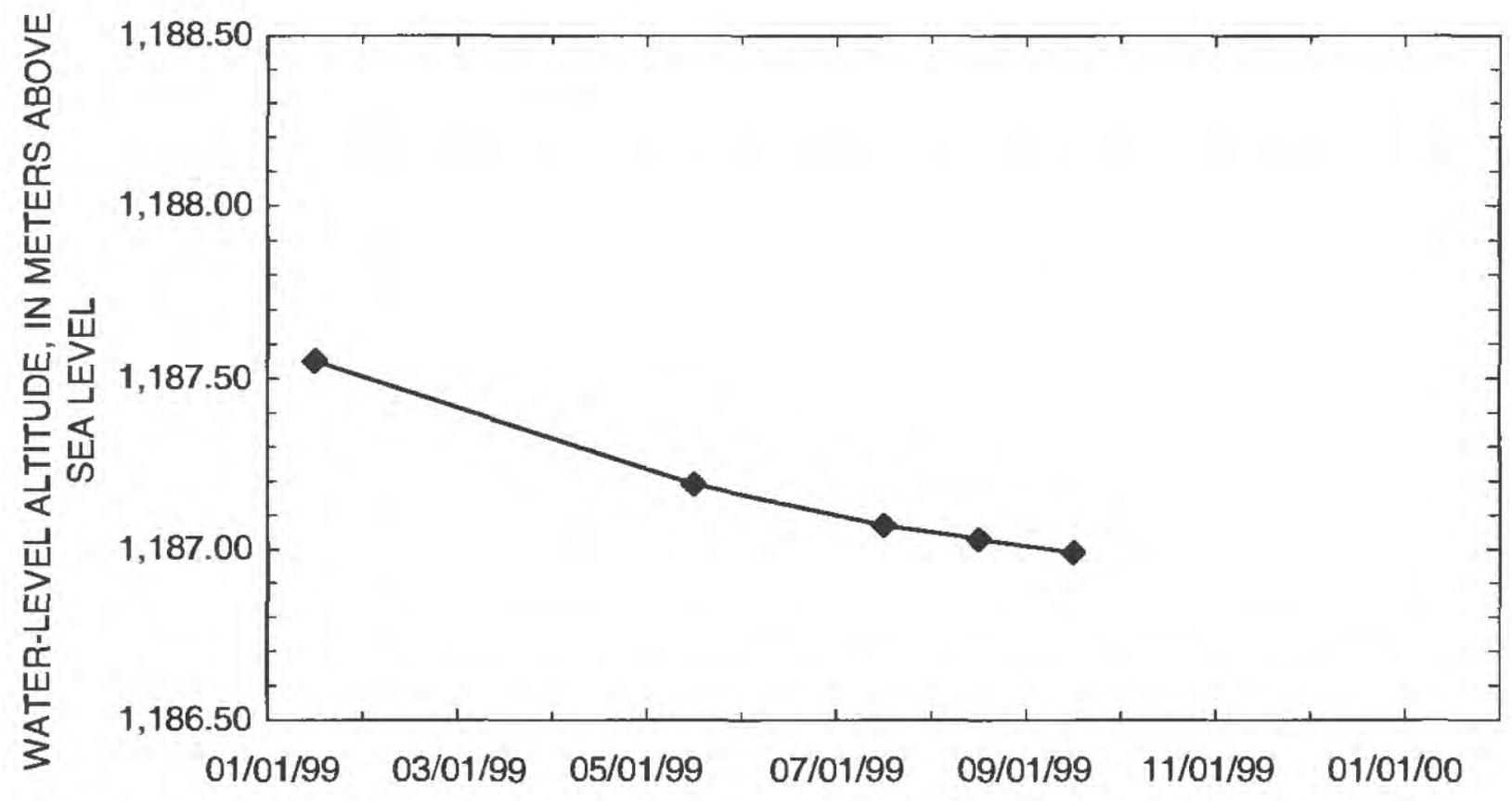

Figure 72. Water-level altitudes for borehole UE-29 UZN \#91 during 1999.

Table 38. Measured water-level altitudes, 1999, for borehole UE-29 UZN \#91

\begin{tabular}{crcc}
\hline Date & Time & $\begin{array}{c}\text { Water-level altitude } \\
\text { (meters above sea } \\
\text { level) }\end{array}$ & $\begin{array}{c}\text { Equipment } \\
\text { used to } \\
\text { measure } \\
\text { water level }\end{array}$ \\
\hline $01 / 07 / 99$ & 1002 & $1,187.55$ & STA-1 \\
$05 / 04 / 99$ & 942 & $1,187.19$ & STA-1 \\
$07 / 14 / 99$ & 1050 & $1,187.07$ & STA-1 \\
$08 / 18 / 99$ & 928 & $1,187.03$ & STA-1 \\
$09 / 23 / 99$ & 1406 & $1,186.99$ & STA-1 \\
\hline
\end{tabular}




\section{REFERENCES CITED}

Blout, D.B., Hammermeister, D.P., Loskot, C.L., and Chornack, M.P., 1994, Geohydrologic data collected from shallow neutron-access boreholes and resultantpreliminary geohydrologic evaluations, Yucca Mountain area, Nye County, Nevada: U.S. Geological Survey Open-File Report 92-657, 147 p.

Boucher, M.S., 1994a, Precision and accuracy of manual water-level measurements taken in the Yucca Mountain area, Nye County, Nevada, 1988-90: U.S. Geological Survey Water- Resources Investigations Report 934025,18 p.

1994b, Water levels in wells J-11 and J-12, 198991, Yucca Mountain area, Nevada: U.S. Geological Survey Open-File Report 94-303, 9 p.

Carr, W.J., 1988, Volcano-tectonic setting of Yucca Mountain and Crater Flat, southwestern Nevada, in Carr, M.D., and Yount, J.C., eds., Geologic and hydrologic investigations of a potential nuclear waste disposal site at Yucca Mountain, southern Nevada: U.S. Geological Survey Bulletin 1790, p. 35-49.

Fenix \& Scisson, Inc., 1986a, NNWSI hole historiesUE-25 WT\#3, UE-25 WT\#4, UE-25 WT\#5, UE-25 WT\#6, UE-25 WT\#12, UE-25 WT\#13, UE-25 WT\#14, UE-25 WT\#15, UE-25 WT\#16, UE-25 WT\#17, UE-25 WT\#18, USW WT-1, USW WT-2, USW WT-7, USW WT- 10, USW WT-11: U.S. Department of Energy DOE/NV/10322-10, 111 p. 1986b, NNWSI hole history-UE-25 p\#1: U.S. Department of Energy DOE/NV/10322-16, 39 p. 1986c, NNWSI hole histories-USW VH-1, USW VH-2: U.S. Department of Energy DOE/ NV/10322$17,57 \mathrm{p}$.

1986d, NNWSI hole histories-UE-29 a \#1, UE-29 a \#2: U.S. Department of Energy DOE/ NV/10322-12, $24 \mathrm{p}$.

1987a, NNWSI hole histories-USW H-1, USW H-3, USW H-4, USW H-5, USW H-6: U.S. Department of Energy DOE/NV/10322-18, 99 p.

-1987b, NNWSI hole histories-Unsaturated zone neutron holes, 76 boreholes drilled between May 1984 and February 1986: U.S. Department of Energy DOE/NV/10322-21, 310 p.

Garber, M.S., and Koopman, F.C., 1968, Methods of measuring water levels in deep wells: U.S. Geological Survey Techniques of Water-Resources Investigations, book 8, chap. A-1, 23 p.

Gemmell, J.M., 1990, Water levels in periodically measured wells in the Yucca Mountain area, Nevada, 1988: U.S. Geological Survey Open-File Report 90-113, $47 \mathrm{p}$.
Graves, R.P., 1998, Water levels in the Yucca Mountain area, Nevada, 1996: U.S.Geological Survey Open-File Report 98-169, 81 p.

2000, Water levels in the Yucca Mountain area, Nevada, 1997-98: U.S. Geological Survey Open-File Report 00-186, 81 p.

Graves, R.P., and Goemaat, R.L., 1998, Water levels in the Yucca Mountain area, Nevada, 1995: U.S. Geological Survey Open-File Report 97-101, 92 p.

Graves, R.P., Tucci, Patrick, and Goemaat, R.L., 1996, Water levels in the Yucca Mountain area, Nevada, 1994: U.S. Geological Survey Open-File Report 95$757,101 \mathrm{p}$.

Graves, R.P., Tucci, Patrick, and O'Brien, G.M., 1997, Analysis of water-level data in the Yucca Mountain area, Nevada, 1985-95: U.S. Geological Survey WaterResources Investigations Report 96-4256, $140 \mathrm{p}$.

Hale, G.S., and Westenburg. C.L., 1995, Selected groundwater data for Yucca Mountain region, southern Nevada and eastern California, calendar year 1993: U.S. Geological Survey Open-File Report 95-158, $67 \mathrm{p}$.

Jones, C.Z., Rowe, T.G., Sexton, R.J., and Tanko, D.J., 2000, Water resources data, Nevada, Water Year 1999: U.S. Geological Survey Water-Data Report NV-99-1, $569 \mathrm{p}$.

La Camera, R.J., and Locke, G.L., 1998, Selected groundwater data for Yucca Mountain region, southern Nevada and eastern California, through December, 1996: U.S. Geological Survey Open-File Report 97821,79 p.

La Camera, R.J., Locke, G.L., and Munson, R.H., 1999, Selected ground-water data for Yucca Mountain region, southern Nevada and eastern California, through December, 1997: U.S. Geological Survey Open-File Report 98-628, 84 p.

La Camera, R.J., and Westenburg, C.L., 1994, Selected ground-water data for Yucca Mountain region, southern Nevada and eastern California, through December, 1992: U.S. Geological Survey Open-File Report 94-54, $161 \mathrm{p}$.

La Camera, R.J., Westenburg, C.L., and Locke, G.L., 1996, Selected ground-water data for Yucca Mountain region, southern Nevada and eastern California, through December, 1995: U.S. Geological Survey Open-File Report 96-553, 75 p.

Lobmeyer, D.H., Luckey, R.R., O’Brien, G.M., and Burkhardt, D.J., 1995, Water levels in continuously monitored wells in the Yucca Mountain area, Nevada, 1989: U.S. Geological Survey Open-File Report 93-098, $173 \mathrm{p}$. 
Luckey, R.R., Lobmeyer, D.H., and Burkhardt, Douglas, 1993, Water levels in continuously monitored wells in the Yucca Mountain area, Nevada, 1985-88: U.S. Geological Survey Open-File Report 91-493, 252 p.

Luckey, R.R., Tucci, Patrick, Faunt, Claudia, Ervin, E.M., Steinkampf, W.C., D'Agnese, F.A., and Patterson, G.L., 1996, Status of understanding of the saturatedzone ground-water flow system at Yucca Mountain, Nevada, as of 1995: U.S. Geological Survey WaterResources Investigations Report 96-4077, 71 p.

O'Brien, G.M., 1991, Water levels in periodically measured wells in the Yucca Mountain area, Nevada, 1989: U.S. Geological Survey Open-File Report 91-178, $51 \mathrm{p}$.

1998, Analysis of aquifer tests conducted in borehole USW G-2, 1996, Yucca Mountain, Nevada: U.S. Geological Survey Water-Resources Investigations Report 98-4063, 22 p.

O’Brien, G.M., Tucci, Patrick, and Burkhardt, D.J., 1995, Water levels in the Yucca Mountain area, Nevada, 1992: U.S. Geological Survey Open-File Report 94-311, $74 \mathrm{p}$.

Preissler, A.M., Roach, G.A., Thomas, K.A., and Wilson, J.W., 1999, Water resources data, Nevada, water year 1998: U.S. Geological Survey Water-Data Report NV-98-1, 598 p.

Robison, J.H., Stephens, D.M., Luckey, R.R., and Baldwin, D.A., 1988, Water levels in periodically measured wells in the Yucca Mountain area, Nevada, 1981-87: U.S. Geological Survey Open-File Report 88-468, $132 \mathrm{p}$.

Sass, J.H., and Lachenbruch, A.H., 1982, Preliminary interpretation of thermal data from the Nevada Test Site: U.S. Geological Survey Open-File Report 82-973, $30 \mathrm{p}$.

Savard, C.S., 1995, Selected hydrologic data from Fortymile Wash in the Yucca Mountain area, Nevada, Water Year 1992: U.S. Geological Survey Open-File Report 94-317, 38 p.

1996, Selected hydrologic data from Fortymile Wash in the Yucca Mountain area, Nevada, Water Years 1993-94: U.S. Geological Survey Open-File Report 95-709, $30 \mathrm{p}$.
1998, Estimated ground-water recharge from streamflow in Fortymile Wash near Yucca Mountain, Nevada: U.S. Geological Survey Water-Resources Investigations Report 97-4273, $30 \mathrm{p}$.

Sawyer. D.A., Fleck, R.J.. Lanphere, M.A., Warren, R.G., Broxton, D.E., and Hudson, M.R., 1994, Episodic caldera volcanism in the Miocene southwestern Nevada volcanic field-Revised stratigraphic framework, ${ }^{40} \mathrm{Ar} /{ }^{39} \mathrm{Ar}$ geochronology, and implications for magmatism and extension: Geological Society of America Bulletin, v. 106, p. 1304-1318.

Tucci, Patrick, Goemaat R.L., and Burkhardt. D.J.. 1996, Water levels in the Yucca Mountain area, Nevada, 1993: U.S. Geological Survey Open-File Report 95-159, $94 \mathrm{p}$.

Tucci, Patrick, O’Brien, G.M., and Burkhardt, D.J., 1996, Water levels in the Yucca Mountain area, Nevada, 1990-91: U.S. Geological Survey Open-File Report 94-111, $107 \mathrm{p}$.

U.S. Department of Energy, 1988, Site characterization plan, Yucca Mountain site, Nevada research and development area, Nevada: U.S. Department of Energy Report DOE RW/0199, 8 v., various pagination.

Waddell, R.K., 1984, Hydrologic and drill-hole data for test wells UE-29a\#1 and UE-29a\#2, Fortymile Canyon, Nevada Test Site: U.S. Geological Survey Open-File Report 84-142, 25 p.

Westenburg, C.L., and La Camera, R.J., 1996, Selected ground-water data for Yucca Mountain region, southern Nevada and eastern California, through December 1994: U.S. Geological Survey Open-File Report 96-205, 73 p.

Young, R.A., 1972, Water supply for the Nuclear Rocket Development Station at the U.S. Atomic Energy Commission's Nevada Test Site: U.S. Geological Survey Water-Supply Paper 1938, 19 p. 